Joachim Reitner, Nadia-Valérie Quéric, Mike Reich (Eds.)

\title{
Geobiology of Stromatolites
}

International Kalkowsky-Symposium,

Göttingen, October 4-11, 2008

Abstract Volume and Field Guide to Excursions

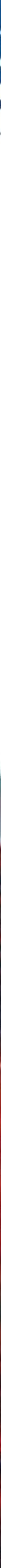

Universitätsdrucke Göttingen

Wo



Joachim Reitner, Nadia-Valérie Quéric, Mike Reich (Eds.) Geobiology of Stromatolites

This work is licensed under the Creative Commons License 2.0 "by-nd", allowing you to download, distribute and print the document in a few copies for private or educational use, given that the document stays unchanged and the creator is mentioned. You are not allowed to sell copies of the free version. 
erschienen in der Reihe der Universitätsdrucke

im Universitätsverlag Göttingen 2008 


\section{Geobiology of Stromatolites}

International

Kalkowsky-Symposium

Göttingen, October 4-11, 2008

Abstract Volume and Field Guide to Excursions

Edited by Joachim Reitner

Nadia-Valérie Quéric and Mike Reich

Geobiologie der Stromatolithe

Internationales Kalkowsky-Symposium,

Göttingen, 04.-11. Oktober 2008

Kurzfassungen der Vorträge und Poster und Exkursionsführer

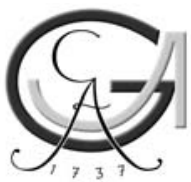

Universitätsverlag Göttingen 2008 


\section{Bibliographische Information der Deutschen Nationalbibliothek}

Die Deutsche Nationalbibliothek verzeichnet diese Publikation in der Deutschen Nationalbibliographie; detaillierte bibliographische Daten sind im Internet über $<$ http://dnb.ddb.de $>$ abrufbar.

\section{Editorial contact}

Prof. Dr. Joachim Reitner, Mag. Nadia-Valérie Quéric, Dr. Mike Reich

Geoscience Centre of the

University of Göttingen

Goldschmidtstraße 3-5

37077 Göttingen

http://www.geobiologie.uni-goettingen.de

http://www.geomuseum.uni-goettingen.de

This work is protected by German Intellectual Property Right Law.

It is also available as an Open Access version through the publisher's homepage and the Online Catalogue of the State and University Library of Goettingen (http://www.sub.uni-goettingen.de). Users of the free online version are invited to read, download and distribute it. Users may also print a small number for educational or private use. However they may not sell print versions of the online book.

Graphics and Layout : Dr. Mike Reich

Cover Design : Conny Kaubisch, Dr. Mike Reich

Cover Photos: Gerhard Hundertmark

Photo Credits:

Stromatolites: Mesabi-Range, Minnesota, USA, Palaeoproterozoic

Drawing: Kalkowsky, E. (1908), Oolith und Stromatolith im norddeutschen Buntsandstein'. Zeitschrift der Deutschen geologischen Gesellschaft 60: 68-125 (3 figs., pls. IV-XI).

Signature: Guest book of the 'Neues Geologisches Museum Göttingen'

(Inaugurated at the general meeting of the Deutsche Geologische Gesellschaft, September 25-28, 1878)

(C) 2008 Universitätsverlag Göttingen

http:/ / univerlag.uni-goettingen.de

ISBN: 978-3-940344-52-6 


\section{Contents}

Preface

E. Kalkowsky - biography

Gehler, A. \& Reich, M.: „Ernst Louis Kalkowsky (1851-1938) and the term "stromatolite""

Plenary talk

Stackebrandt, E.: „Nicht jeder Tropfen böhlt den Stein: Stromatolithe aus geomikrobiologischer Sicht"

\section{Keynotes}

[Brocks, J. J.; Decho, A. W. et al.; Ferris, F. G.; Kano, A. et al.; Kato, K.; Krüger, M. et al.; Reid, R. P. et al.; Riding, R.; Taviani, M.; Thorseth, I. H.; Van Kranendonk, M. J.; Westall, F.]

\section{Abstracts}

[in alphabetical order]

\section{Excursion A: Pre-Conference Field Trip}

Paul, J.; Arp, G. \& Reitner, J.: „Kalkowsky's type stromatolites and other microbialites of Lower Saxony"

\section{Excursion B: Post-Conference Field Trip}

Arp, G.: „Fossil and present-day stromatolites of southern Germany“ 168

Index of authors 203 



\section{Preface}

Stromatolites are the most intriguing geobiological structures of the entire history of the earth since the early beginning of the fossil record in the Archaean. Traditionally, stromatolites and related microbial sediments are interpreted as biosedimentological remains of biofilms and microbial mats.

The Geobiology Group in Göttingen has successfully been granted a large international research project to solve many of these open questions. Therefore, this symposium is organised under the auspices of the DFG-Research Unit FOR 571 "Geobiology of Organo- and Biofilms" and the Courant Research Centre Geobiology, which is part of the German Federal Excellence Initiative.

However, one group on their own cannot answer all open questions, and therefore we have planned and organised the stromatolites symposium in Göttingen together with our international colleagues and friends. This meeting somewhat stands in the tradition of the "Death Valley International Stromatolite Symposium", which was very successfully organised by Stanley M. Awramik and Robert Riding in 1994. This meeting has given us new and exceptional ideas and information of the formation and environmental setting of stromatolites, and we hope that the symposium in Göttingen will deliver us new insights into the scientific progress of this topic, which has taken place during the past 14 years.

The symposium is dedicated to Ernst Louis Kalkowsky (1851-1938), who has introduced the terms "Stromatolith" ['stromatolite'] and "Ooid" ['ooid'] to the earth science community in 1908.

2008 is the $100^{\text {th }}$ anniversary of his remarkable publication „Oolith und Stromatolith im norddeutschen Buntsandstein." published in the "Zeitschrift der Deutschen geologischen Gesellschaft".

More than 120 scientists from various interdisciplinary fields, e. g. biology, microbiology, biogeochemistry, geology, sedimentology, from 19 countries world-wide will join the meeting and present their most recent research on stromatolites and related topics.

The symposium is flanked by a field trip to the classical outcrops of Kalkowsky's stromatolites in eastern Lower Saxony (Northern Germany) and a trip to Bavaria (Southern Germany) to the famous outcrops in the Ries-Meteorite Crater, Solnhofen Lithographic limestones, and modern freshwater tufa deposits.

During the symposium, three workshops will be offered dealing with geohistology, Raman spectroscopy, and EPS-ExoPolymeric Substances.

A concomitant event of the symposium will be a special exhibition of stromatolites and various microbial sediments in the rooms of the Geoscience Museum of the 
Geoscience Centre of the University of Göttingen (GZG). It is entitled: "How Bacteria Design the World. Architects of the Global Change in the last 3.6 Billion Years".

We wish all participants of the symposium a very successful meeting and that intriguing new information and new ideas for research projects will be the result, and, last but not least, that new colleagues and friends for future successful cooperation will be found.

Joachim Reitner, Gernot Arp, Nadia V. Quéric \& Mike Reich, October 2008 


\title{
Ernst Louis Kalkowsky (1851-1938) and the term 'stromatolite'
}

\author{
Alexander Gehler ${ }^{1} \&$ Mike Reich ${ }^{2}$ \\ ${ }^{1}$ Georg-August-Universität Göttingen, Geowissenschaftliches Zentrum, Abt. Geobiologie, Göttingen, \\ Germany; E-mail:agehlen@gwdg.de \\ ${ }^{2}$ Georg-August-Universität Göttingen, Geowissenschaftliches Zentrum, Museum, Sammlungen \& \\ Geopark, Göttingen, Germany; E-mail: mreich@gwdg.de
}

\section{Introduction}

Today, stromatolites are well investigated and known worldwide, from the Archaean to Recent. Only 100 years ago, the situation was completely different. As late as in the early 20th century, the German Professor Ernst Louis Kalkowsky (18511938; Fig. 1) was engaged intensively in the research of stromatolitic and oolitic structures from the German Buntsandstein (Early Triassic), and interpreted them (Kalkowsky 1908; Fig. 2). Especially in the case of stromatolites, his views have high relevance until now. He also established the terms "Stromatolith" [= "stromatolite"] and "Ooid" [= "ooid'], which were later universally accepted for analogous structures (e. g. Paul \& Peryt 1985).

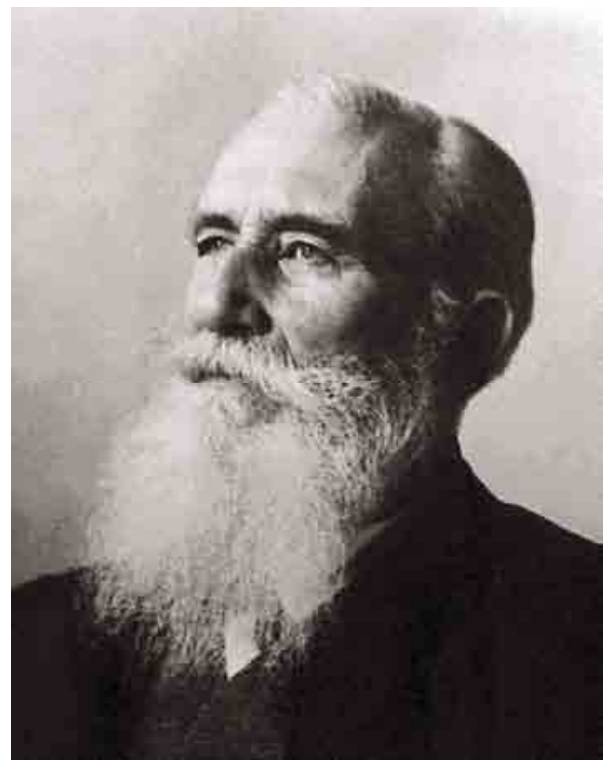

Fig. 1. Ernst Louis Kalkowsky, photograph taken around 1928. [C Staatliche Naturhistorische Sammlungen Dresden, Museum für Mineralogie und Geologie, Archiv]

\section{Oolith und Stromatolith} im norddeutsehen Buntsandstein.

Von Herrn Ersst KaLKowsky in Dresden. Hierzu Tafel IV-XI and 3 Textfigaren.

1. Û̉ber die Entstehung der Oolithe sind seit nahezu zweihundert Jahren die mannigfaltigsten Ansichten ausgesprochen worden, die sich auf mancherlei Beobachtungen, besonders aber auf theoretische Studien stützten. Es gewann wohl die Ansicht das Ûbergewicht, die in den Kalkkügelchen der Oolithe anorganische Niederschläge aus dem Meereswasser in der Nähe des Strandes erblickte. Neuerdings sind nun die Kalkkügelehen als phytogen gedeutet worden, als erzeugt durch die Lebenstilitigkeit niedriger Pflanzen.

Unter allen Oolithen sind es die Rogensteine im Buntsandstein Norddeutschlands, die den Anlab zur Benennung dieses Kalksteintypus gegeben haben; das Vorkommen und die Verbreitung dieser Kalksteine ist allgemein bekannt, so daB darūber an dieser Stelle nichts gesagt zu werden braucht.

2. Mikroskopische Untersuchungen der Rogensteine sind bereits mehrfach ausgefübrt, aber vielleicht nur zum Teil veroffentlicht worden. Aber sei es, daB das Material nicht in genũgender Welse zur Verfügung gestanden hat, sei es, dab die Untersuchungen von einem unzutreffenden Gesichtspunkte aus ausgefūhrt wurden, es ergibt sich, daß uีber viele Erscheinungen des Aufbaues der Körner der Rogensteine bisher keine Mitteilungen veröffentlicht worden sind. Aus dem Aufbau der Körner ergibt sich die Art der Entstehung in unzweideutiger Weise, sobald man dabei außer den Oolithen auch die Stromatolithe berücksichtigt.

3. Unter dem neuen Namen Stromatolith werden Kalksteinmassen von besonderer Struktur und besonderem Aufbau verstanden, die mit dem Rogenstein im norddeutschen Buntsandstein zusammen vorkommen. Aus der deutschen geologischen Literatur sind diese auffalligen Massen in neuerer Zeit vollkommen verschwunden, nachdem sie auch frūher nur kurz und ohne ihrem Wesen nach genauer erkannt zu sein erwibnt

Fig. 2. Title page of E. Kalkowsky's paper "Oolith und Stromatolith im norddeutschen Buntsandstein" in 1908. 


\section{Biographical notes and Kalkowsky's research on stromatolites}

Kalkowsky was born September 9th, 1851 in Tilsit, East Prussia (now Sowetsk, Oblast Kaliningrad, Russia). After achieving his baccalaureate in June 1870 in his hometown, he matriculated at the University of Leipzig in Natural Sciences on October $17^{\text {th }}, 1870$ and received his doctorate in 1874 with a petrographic work on felsites and pitchstones (Fig. 3). Kalkowsky's doctoral advisor was Ferdinand Zirkel (1838-1912), a pioneer in the microscopic research on rocks and minerals.

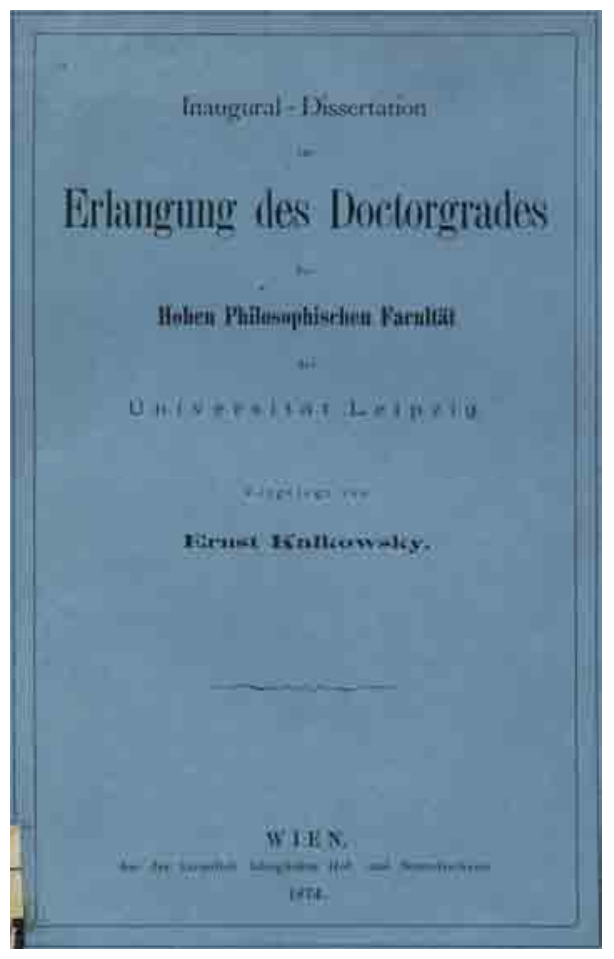

Fig. 3. Title page of E. Kalkowsky's doctoral thesis "Mikroskopische Untersuchungen von Felsiten und Pechsteinen Sachsens" [= "Microscopic investigations on felsites and pitchstones from Saxony'] in 1874.

His habilitation thesis on the gneissic formation of the Silesian Eulengebirge (now Góry Sowie, south-western Poland), the oldest part of the Central European mountain range of the Sudetes, was published in 1878 (Fig. 4).

After an employment as assistant professor under F. Zirkel in Leipzig in 18811882, he worked self-employed in Königsberg (now Kaliningrad, Russia) for a short time, then in Gotha, amongst others for the publishing house "Justus Perthes Geographische Anstalt" (Anonymous 1938; Rimann 1940). 


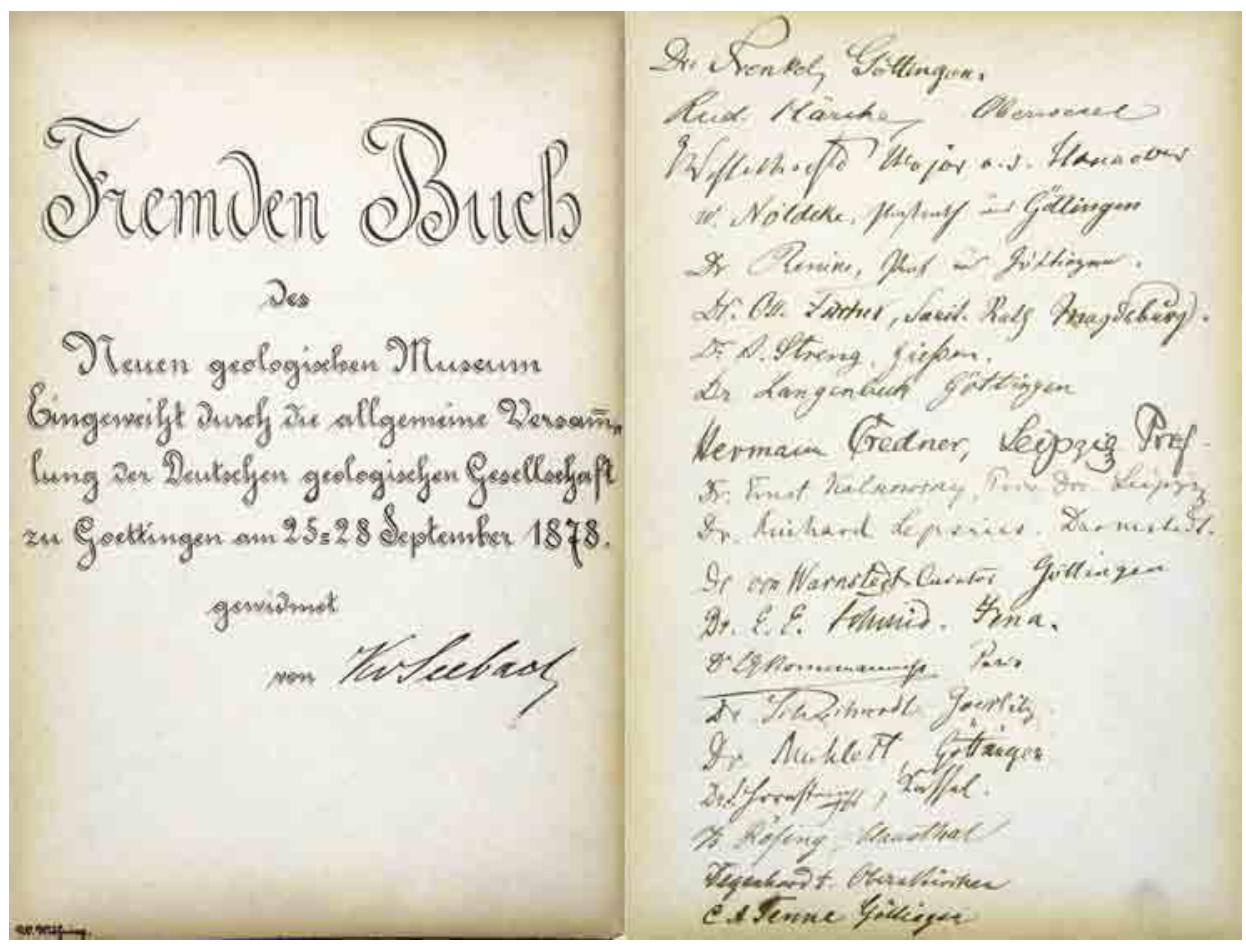

Fig. 4. Signature of Ernst Kalkowsky (as a associate professor, 'Privat-Dozent') during the annual meeting of the German geological Society in Göttingen, September 1878 [guest book of the Geological Museum of Göttingen]. [GZG.A.00010]

In 1886, he followed an appointment to the chair of mineralogy and geology in Jena, first employed as associate professor, from 1887 on as a full professor. He also obtained the head office of the "Grand duke's Museum of Mineralogy". Eight years later, in April 1894, he moved to Dresden (Fig. 5) and succeeded Hanns Bruno Geinitz (1814-1900) as chair of mineralogy and geology. In April 1898 he additionally assumed the direction of the "State Museum of Mineralogy and Geology", including the department of prehistory in Dresden, which was still occupied by Geinitz until then. For the next 25 years, Kalkowsky enriched and advanced the research at his faculty and the exhibition of the museum in an extraordinary way. In 1907 he was promoted to privy counsellor ("Geheimer Hofrat"). Kalkowsky retired and received emeritus status October 1 1st, 19191.

Kalkowsky died on February 13 ${ }^{\text {th }}, 1938$ in Dresden. His obituary was published in the "Zeitschrift der Deutschen geologischen Gesellschaft", of which he was a member for more than 64 years (Anonymous 1938). After cremation, his urn was entombed at the cemetery Paulinzella-Rudolstadt (Thuringia, Germany).

1 early in 1920, after several authors (Rimann 1940, Mathé 1993); October 1 ${ }^{\text {st }}, 1919$ after Anonymous (1938) and the personnel file of E. Kalkowsky, Technical University of Dresden 


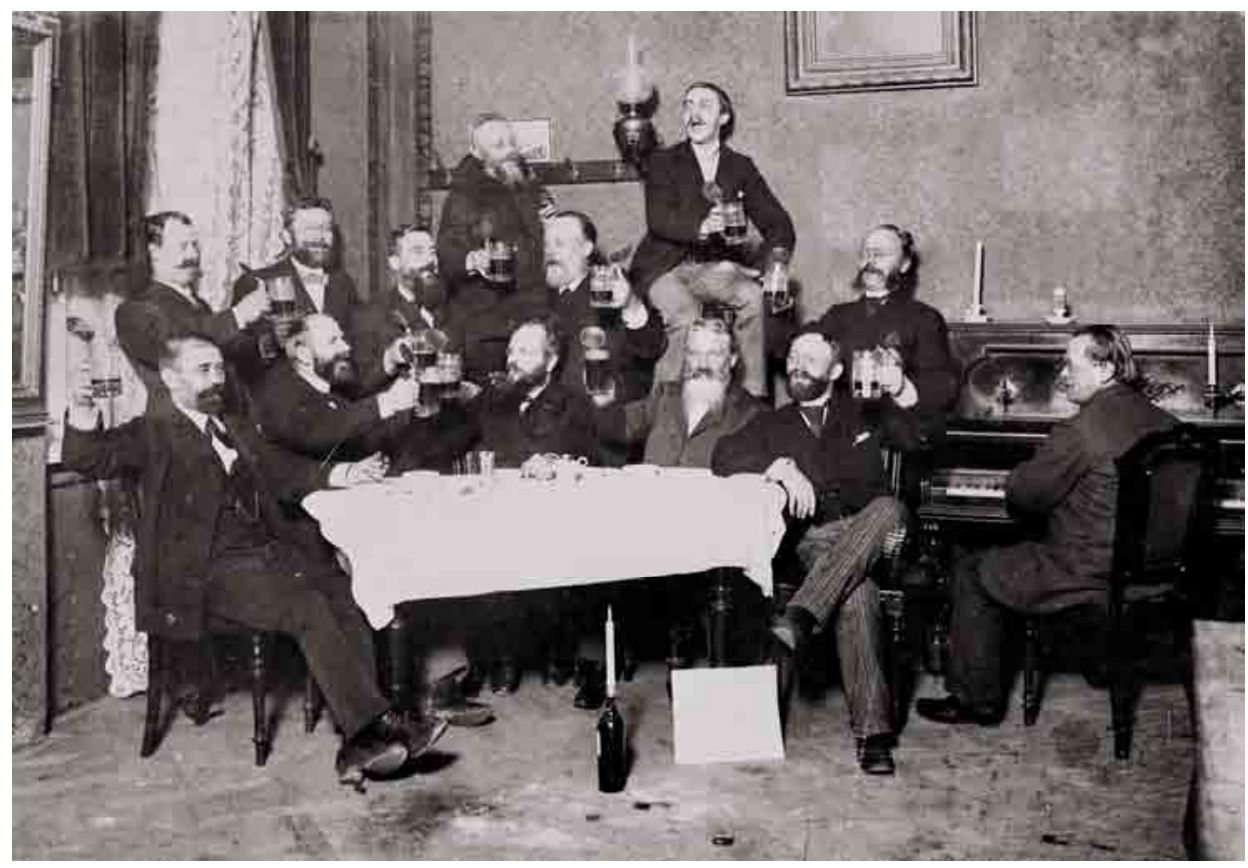

Fig. 5. Ernst Louis Kalkowsky [2 [2d row, $3^{\text {rd }}$ from left] with colleagues during a meeting in Dresden on December 19th 1895 . [C SLUB Dresden / Deutsche Fotothek]

Even back in his school days, Kalkowsky was very passionate of mineralogy and geology. In those early times, the desire to become a professor of mineralogy emerged. Knowing this, his subsequent enthusiasm and meticulousness in this research topic is not surprising.

In the first 20 years of his scientific career after his doctor's degree, his research was mostly dedicated to optical mineralogy following the successful research of his doctoral advisor F. Zirkel in this new field of geology. In that period, Kalkowsky deals with this subject in more than 25 papers, especially regarding the regional rock formations of Saxony (Rimann 1940; Mathé 1993).

His first and only comprehensive textbook "Elemente der Lithologie" (1886) was also published in this phase of his life.

After becoming the professorship ordinary of mineralogy and geology at Dresden University, the demands of teaching and administration caused a certain decrease in his publication practice (Rimann 1940). Nevertheless, he developed a strong interest in nephrite, an amphibole mineral of the solid solution series of tremolite and actinolite. This is expressed in four substantial papers on this matter.

Considering Palaeontology an ancillary science - belonging more to biology than to geology - Kalkowsky was strongly reserved in any research on this topic 
(Rimann 1940). However, with his paper "Oolith und Stromatolith im norddeutschen Buntsandstein" (1908; Fig. 2), in which he investigates oolitic and stromatolitic structures of the Lower Triassic in the Subhercynian Basin (Lower Saxony \& Saxony-Anhalt, Germany), he provides an innovative contribution to all later research concerning stromatolitic structures.

In this paper, Kalkowsky proposed and defined the term „Stromatolith“; furthermore, he followed and strengthened the suggestion that these oolitic and stromatolitic structures are organosedimentary deposits. This was first mentioned by Ludwig \& Theobald (1852) regarding the thermal waters of Bad Nauheim (Hesse, Germany) (e. g. Krumbein 2008).

Initially, his conclusions were doubted by most geologists in Germany (e. g. Reis 1908; Voss 1928), it was not until several years after his death that they were finally accepted in general. Today, exactly 100 years after Kalkowsky's pioneering work, his view of stromatolites is still not far from the modern interpretation of this term.

Therefore the knowledge of analogous structures he observed during various field trips, e. g. in Russia (Devonian), Germany (Permian and Upper Jurassic), England (Permian and Upper Triassic), and France (Neogene), was very helpful for him (Kalkowsky 1908; Rimann 1940).

Beside the scientific research, Kalkowsky was a distinguished teacher and a brilliant museum scientist. Having already gained fundamental experience in Jena, he successfully restructured the exhibition of the State Museum for mineralogy, geology and prehistory under modern aspects in his Dresden times (Rimann 1940; Mathé 1993).

Beyond this, Kalkowsky's dedication for the "Naturwissenschaftliche Gesellschaft Isis in Dresden" should be acknowledged. Shortly after his appointment in Dresden, he assumed the position of the vice-chairman of the mineralogical division of Isis; in December 1896, he became chairman. Kalkowsky held this position until 1919. Additionally, he presided over the entire society in the years 1899-1900 and 19071908. Anticipatory to his $70^{\text {th }}$ birthday, he was appointed an honorary member of the society in November 1920 (Rimann 1940). 


\section{Publications of E. Kalkowsky}

Kalkowsky, E. (1874a): Mikroskopische Untersuchungen von Felsiten und Pechsteinen Sachsens. Mineralogische Mittheilungen [1874] (I): 31-58. [= „Doctoral thesis“]

Kalkowsky, E. (1874b): Die augithaltenden Felsitporphyre bei Leipzig. Zeitschrift der Deutschen geologischen Gesellschaft 26: 586-599.

Kalkowsky, E. (1875a): Mikroskopische Untersuchung des Glimmertrapps von Metzdorf. Neues Jabrbuch für Mineralogie, Geologie und Palaeontologie [1875]: 488-505.

Kalkowsky, E. (1875b): Ueber den Salit als Gesteinsgemengtheil. Mineralogische Mittheilungen [1875] (II): 45-50.

Kalkowsky, E. (1875c): Rother Gneiss und Kalkstein im Wilischthal im Erzgebirge. Zeitschrift der Deutschen geologischen Gesellschaft 27: 623-630, 1 fig.

Kalkowsky, E. (1876a): Über einige Eruptivgesteine des sächsischen Erzgebirges. Neues Jahrbuch für Mineralogie, Geologie und Palaeontologie [1876]: 136-161.

Kalkowsky, E. (1876b): Mittheilungen an Prof. G. Leonhard [Erwiderung an G. v. Rath das Tannenbergsthaler Gestein betreffend]. Neues Jabrbuch für Mineralogie, Geologie und Palaeontologie [1876]: 623-626.

Kalkowsky, E. (1876c): Ueber grüne Schiefer Niederschlesiens. Mineralogische Mittheilungen [1876] (II): 87-116, 1 table, pl. VIII.

Kalkowsky, E. (1876d): Das Glimmerschiefergebiet von Zschopau im sächsischen Erzgebirge. Zeitschrift der Deutschen geologischen Gesellschaft 28: 682-749, (1 table), pl. X.

Kalkowsky, E. (1877): Herr E. Kalkowsky an Herrn K. A. Lossen [Rother Gneiss im Erzgebirge]. Zeitschrift der Deutschen geologischen Gesellschaft 29: 837-840.

Kalkowsky, E. (1878a): Die Gneissformation des Eulengebirges. VI +75 pp., 3 pls.; Leipzig (Engelmann). [ $=$ „Habilitationsschrift durch welche unter Zustimmung der Philosophischen Facultät der Universität Leipzig zu seiner Sonnabend den 2. Februar 1878 Nachmittags 3 Uhr im Auditorium Nro. 6 im Bornerianum zu haltenden Probevorlesung über Mineralquellen einladet...; „Habilitation thesis“]

Kalkowsky, E. (1878b): Der Granitporphyr von Beucha bei Leipzig. Neues Jahrbuch für Mineralogie, Geologie und Palaeontologie [1878]: 276-286.

Kalkowsky, E. (1878c): Der Leucitophyr vom Averner See. Neues Jabrbuch für Mineralogie, Geologie und Palaeontologie [1878]: 727-729.

Kalkowsky, E. (1878d): Ueber den Piperno. Zeitschrift der Deutschen geologischen Gesellschaft 30: 663-677, (1 table).

Kalkowsky, E. (1879a): Über die Thonschiefernädelchen. Neues Jabrbuch für Mineralogie, Geologie und Palaeontologie [1879]: 382-387.

Kalkowsky, E. (1879b): Ueber Krystallsystem und Zwillingsbildung des Tenorites. Zeitschrift für Krystallographie und Mineralogie 3 (III): 279-287, pl. VI (9-10).

Kalkowsky, E. (1880a): Ueber die Erforschung der archäischen Formationen. Neues Jahrbuch für Mineralogie, Geologie und Palaeontologie [1880] (1): 1-28.

Kalkowsky, E. (1880b): Ueber Gneiss und Granit des bojischen Gneissstockwerkes im Oberpfälzer Waldgebirge. Neues Jahrbuch für Mineralogie, Geologie und Palaeontologie [1880] (1): 29-42, pl. I. 
Kalkowsky, E. (1881a): Ueber Hercynit im sächsischen Granulit. Zeitschrift der Deutschen geologischen Gesellschaft 33: 533-539.

Kalkowsky, E. (1881b): Ueber den Ursprung der granitischen Gänge im Granulit in Sachsen. Ein Beitrag zur Kenntniss des Granites. Zeitschrift der Deutschen geologischen Gesellschaft 33: 629-653, (1 table).

Kalkowsky, E. (1882): Einige Beobachtungen im sächsischen Granulitgebirge. Neues Jahrbuch für Mineralogie, Geologie und Palaeontologie [1882] (1): 231-233.

Kalkowsky, E. (1884): Ueber die Polarisationsverhältnisse von senkrecht gegen eine optische Axe geschnittenen zweiaxigen Krystallplatten. Zeitschrift für Krystallographie und Mineralogie 9 (V-VI): 486-497, pl. XIII.

Kalkowsky, E. (1885): Ueber Olivinzwillinge in Gesteinen. Zeitschrift für Krystallographie und Mineralogie 10 (I): 17-24, pl. II.

Kalkowsky, E. (1886a): Elemente der Lithologie. Für Studierende bearbeitet. VIII + 316 pp., (31 tables); Heidelberg (Winter).

Kalkowsky, E. (1886b): Ueber Struvit von Homburg. Zeitschrift für Krystallographie und Mineralogie 11 (I): 1-4, (1 table). pl. I.

Kalkowsky, E. (1893): Ueber Geröll-Thonschiefer glacialen Ursprungs im Kulm des Frankenwaldes. Zeitschrift der Deutschen geologischen Gesellschaft 45: 69-86.

Kalkowsky, E. (1894): Mineralogie und Geologie an der Technischen Hochschule. Antrittsrede von Dr. Ernst Kalkowsky, Professor an der Technischen Hochschule zu Dresden. Der Civilingenieur (N. F.) 40 (4): 301-312.

Kalkowsky, E. (1897a): Das neue min.-geologische Institut der Kgl. Techn. Hochschule zu Dresden. Sitzungsberichte und Abhandlungen der Naturwissenschaftlichen Gesellschaft Isis in Dresden [1896] (2; July-December): 27-29.

Kalkowsky, E. (1897b): Ueber einen oligocänen Sandsteingang an der Lausitzer Ueberschiebung bei Weinböhla in Sachsen. Sitzungsberichte und Abhandlungen der Naturwissenschaftlichen Gesellschaft Isis in Dresden [1897] (1; January-June): 80-89, pl. III.

Kalkowsky, E. (1900): Hanns Bruno Geinitz. Die Arbeit seines Lebens. Rede in der öffentlichen Sitzung der Isis am 22. Februar 1900. Sitzungsberichte und Abbandlungen der Naturwissenschaftlichen Gesellschaft Isis in Dresden [1900] (1; January-June): V-XIII.

Kalkowsky, E. (1902): Die Verkieselung der Gesteine in der nördlichen Kalahari. Sitzungsberichte und Abhandlungen der Naturwissenschaftlichen Gesellschaft Isis in Dresden [1901] (2; July-December): 55-107, pls. II-IV.

Kalkowsky, E. (1905): Die Markasit-Patina der Pfahlbau-Nephrite. Sitzungsberichte und Abhandlungen der Naturwissenschaftlichen Gesellschaft „Isis" in Dresden [1904] (2; JulyDecember): 51-60, 1 fig.

Kalkowsky, E. (1906a): Der Nephrit des Bodensees. Sitzungsberichte und Abhandlungen der Naturwissenschaftlichen Gesellschaft „Isis" in Dresden [1906] (1; January-June): 28-44, 1 fig.

Kalkowsky, E. (1906b): Geologie des Nephrites im südlichen Ligurien. Zeitschrift der Deutschen geologischen Gesellschaft 58: 307-378, (7 tables), pl. XVIII.

Kalkowsky, E. (1907a): Die natürlichen Verhältnisse Dresdens. 1. Geologischer Aufbau, Wasserhorizonte, Bodenbeschaffenheit. In: Schäfer, F. (ed.): Wissenschaftlicher Führer durch Dresden. [79. Versammlung Deutscher Natur-Forscher und Ärzte]. pp. 1-3; Dresden (v. Zahn \& Jaensch). 
Kalkowsky, E. (1907b): Die naturwissenschaftlichen Anstalten Dresdens. 3. Das Mineralogisch-Geologische Institut der Technischen Hochschule. In: Schäfer, F. (ed.): Wissenschaftlicher Fübrer durch Dresden. [79. Versammlung Deutscher Natur-Forscher und Ärate]. pp. 53-55; Dresden (v. Zahn \& Jaensch).

Kalkowsky, E. (1907c): Technische Behörden und Anstalten und naturwissenschaftliche Museen Dresdens. 6. Das Königliche Mineralogisch-Geologische Museum, nebst der Prähistorischen Sammlung im Königlichen Zwinger. In: Schäfer, F. (ed.): Wissenschaftlicher Führer durch Dresden. [79. Versammlung Deutscher Natur-Forscher und Ärte]. pp. 112-114; Dresden (v. Zahn \& Jaensch).

Kalkowsky, E. (1907d): Geologische Deutung des Nephrites von Gulbashen. In: Bauer, M.; Koken, E. \& Liebisch, T. (eds.): Festband zur Feier des 100jährigen Bestehens. Neues Jabrbuch für Mineralogie, Geologie und Palaeontologie [1907]: 159-168.

Kalkowsky, E. (1908a): Der Korundgranulit von Waldheim in Sachsen. Sitzungsberichte und Abhandlungen der Naturwissenschaftlichen Gesellschaft "Isis" in Dresden [1907] (2; JulyDecember): 47-65.

Kalkowsky, E. (1908b): Oolith und Stromatolith im norddeutschen Buntsandstein. Zeitschrift der Deutschen geologischen Gesellschaft 60: 68-125, 3 figs., pls. IV-XI.

Kalkowsky, E. (1908c): 53. Hauptversammlung der Deutschen geologischen Gesellschaft. Begrüßungsworte. Zeitschrift der Deutschen geologischen Gesellschaft, Monatsberichte 60 (8/10): 191-195.

Beck, R., Credner, H., Gäbert, C., Hibsch, J. E. \& Kalkowsky, E. (1908): Exkursions-Pläne für die 53. allgemeine Versammlung der Deutschen geologischen Gesellschaft in Dresden. - 20 pp., 12 figs., pls. I-V; Berlin (Schade).

Kalkowsky, E. (1909a): Europäische Entfernungen. Sitzungsberichte und Abhandlungen der Naturwissenschaftlichen Gesellschaft „Isis" in Dresden [1908] (2; July-December): 33-40, (6 tables).

Kalkowsky, E. (1909b): Bericht über die Exkursionen an den Versammlungstagen. Zeitschrift der Deutschen geologischen Gesellschaft, Monatsberichte 61 (2): 90-93.

Kalkowsky, E. (1909c): Geologische Grundlagen der Entwicklungslehre. Sitzungsberichte und Abhandlungen der Naturwissenschaftlichen Gesellschaft „Isis“ in Dresden [1909] (1; JanuaryJune): 3-10.

Kalkowsky, E. (1910): Geologie und Phantasie. Vortrag bei der Feier des 75jährigen Bestehens der Naturwissenschaftlichen Gesellschaft „Isis“ am 26. Mai 1910. Sitzungsberichte und Abhandlungen der Naturwissenschaftlichen Gesellschaft „Isis" in Dresden [1910] (1; January-June): 10-19.

Kalkowsky, E. (1915a): Aluminokrate Schlieren im Frankensteiner Gabbro im Odenwald. Sitzungsberichte und Abhandlungen der Naturwissenschaftlichen Gesellschaft „Isis" in Dresden [1914] (2; July-December): 33-42.

Kalkowsky, E. (1915b): Opaleszierender Quarz. Zeitschrift für Krystallographie und Mineralogie 55 (I): 23-50, pl. III.

Kalkowsky, E. (1921): Mikroskopischer Coelestin im Röt von Jena als geologische Erscheinung. Zeitschrift der Deutschen geologischen Gesellschaft 73: 1-23. 


\section{Cited references}

Anonymous 1938. [obituary to E. L. Kalkowsky]. Zeitschrift der Deutschen geologischen Gesellschaft 90: p. 173.

Kalkowsky, E. 1908. Oolith und Stromatolith im norddeutschen Buntsandstein. Zeitschrift der Deutschen geologischen Gesellschaft 60: 68-125, 3 figs., pls. IV-XI.

Krumbein, W. E. 2008. Biogenerated Rock Structures. Space Science Reviews 135: 81-94.

Ludwig, R. \& Theobald, G. 1852. Ueber die Mitwirkung der Pflanzen bei der Ablagerung des kohlensauren Kalkes. Annalen für Physik und Chemie 87: 91-107.

Mathé, G. 1993. Ernst Kalkowsky (1851-1938). Geologe, Hochschullehrer und Museumsdirektor. Abhandlungen des Staatlichen Museums für Mineralogie und Geologie zu Dresden 39: 7-20.

Paul, J. \& Peryt, T. M. 1985. Oolithe und Stromatholithen im Unteren Buntsandstein des Heeseberges bei Jerxheim, Kreis Wolfenbüttel. Bericht der Naturbistorischen Gesellschaft Hannover 128: 175186.

Reis, O. M. 1908. [Referat zu:] Kalkowsky: Ueber Oolith und Stromatolith im norddeutschen Buntsandstein. Neues Jabrbuch für Mineralogie, Geologie und Paläontologie [1908] (2): 114-138.

Rimann, E. 1940. Ernst Kalkowsky, sein Leben und sein Werk. Sitzungsbericbte und Abhandlungen der Naturwissenschaftlichen Gesellschaft Isis in Dresden [1938/39]: 69-95.

Voss, R. 1928. Die paläogeographische Verbreitung des Rogensteins im deutschen Unteren Buntsandstein. Abhandlungen der Preußischen Geologischen Landesanstalt (N. F.) 107: 1-66. 


\section{Plenary talk}

\section{Nicht jeder Tropfen höhlt den Stein: Stromatolithe aus geo- mikrobiologischer Sicht}

Erko Stackebrandt

Deutsche Sammlung von Mikroorganismen und Zellkulturen GmbH, Braunschweig, Germany; E-mail: erko@dsmz.de

Stromatolithe, Schichtsteine, sind Ergebnisse eines Prozesses anorganischer und organischer Interaktionen, der von der frühesten Evolution des Lebens (vor 3,4 Milliarden Jahren) wahrscheinlich unverändert bis heute nach dem gleichen Prinzip abläuft. Lediglich die Evolution der beteiligten Mikroorganismen sorgte für Variationen des Themas, während die Chemie unbeeinflusst blieb. Im flachen marinen Bereich, aber auch in Bächen werden ausgehend von einem Biofilm durch die Stoffwechselaktivität von Mikroorganismen gefällte Stoffe und Sedimentpartikel periodisch abgelagert, die nach Mineralisierung dem Stromatolithen die charakteristische innere Struktur geben. Äußerlich von einem Laien nicht unbedingt als geo-mikrobiologisches Zusammenspiel zu erkennen, entfaltet das Sedimentgestein im Anschliff die Ästhetik der fein-geschichteten Knollen und Säulen. Die Ursache der Sedimentation und der chemisch bedingten Ausfällung von Kalziumkarbonat wird intensiv erforscht und die Rolle der Cyanobakterien (früher Blaualgen) als Verantwortliche für die Sauerstoffatmosphäre und die Bildung von Eisenlagerstätten hervorgehoben. Fossilien geologisch alter Stromatolithe wurden in Anlehnung an die Morphologie rezenter Formen als Cyanobakterien-ähnlich interpretiert, aber jüngst entwickelte Methoden konnten das Zusammenspiel hoch- diverser Lebensgemeinschaften nachweisen. Die Bildung von Stromatolithen beruht nicht auf der Aktivität einiger weniger Bakterien sondern auf komplex aufgebauten und horizontal im mm-Bereich geschichteten Biofilmen, die durch stoffwechselphysiologische Wechselwirkungen den Mineralisierungsprozess steuern.

Der Vortrag soll die entscheidende Rolle von Mikroorganismen an der Gestaltung der Erdatmosphäre darstellen, für die Stromatolithe die einzigen Zeugen darstellen. Er soll darüberhinaus neue methodische Entwicklungen aufzeigen, ohne die eine Korrelation der Struktur von Lebensgemeinschaften mit deren Funktion nicht möglich ist. Nicht zuletzt soll die Schönheit der Synthese geologisch alter Interaktionen zwischen Biologie und Geologie vermittelt werden. 


\section{Keynotes}

\section{Molecular fossils and the evolution of eukaryotes in the Pre- cambrian [keynote]}

Jochen J. Brocks

Research School of Earth Sciences, The Australian National University, 0200 Canberra, Australia; E-mail:jochen.brocks@anu.edu.au

Microfossils and molecular fossils (biomarkers) found in Precambrian sedimentary rocks tell different stories about the diversity and evolution of early eukaryotes. What information do these records contain, and can they be reconciled?

The oldest microfossils that have a possible eukaryotic origin date back to $\sim 1.9$ billion years $(\mathrm{Ga})$, and fossils with characteristics that are diagnostic of a eukaryotic cytoskeleton - processes, protrusions and complex cell wall ornamentation - come from the $1.49 \mathrm{Ga}$ old Roper Group, McArthur Basin, northern Australia (Javaux et al. 2001). However, in contrast to most younger assemblages, these relatively complex Mesoproterozoic eukaryotes primarily inhabited agitated and well-oxygenated shoreline facies. Eukaryotes in deep off-shore environments remained small, simple and rare. The first eukaryote recognized as a member of a known kingdom, the red alga Bangiomorpha, appears in the geological record $\sim 1.2 \mathrm{Ga}$ ago (Butterfield et al. 1990), and the first possible yellow-green algae (Xanthophyceae), a group of heterokonts that contains a red-algal secondary endosymbiont, is recorded in $\sim 1.0 \mathrm{Ga}$ old strata (Butterfield 2004). The first green algae (Butterfield et al. 2004) and testate amoebae (Porter \& Knoll 2000) appear in the geological record $0.75 \mathrm{Ga}$ ago. Convincing evidence for animals, at this stage still mere clusters of cells, was detected in $0.6 \mathrm{Ga}$ old phosphorites in China (Xiao et al. 1998). However, generally eukaryotic diversity and abundance remained low until the Ediacaran (0.632-0.542 Ga) (Knoll et al. 2006), and the persistence of eukaryotic fossils with similar morphologies over time intervals of hundreds of millions of years suggests that the evolutionary pace to new eukaryotic forms and shapes remained an order of magnitude slower than in the Phanerozoic (Knoll 1994).

The protracted transition from a low diversity of simple and small eukaryotic forms in the Palaeoproterozoic to higher abundance, variety and complexity in the late Neoproterozoic should also have left a distinct fossil record of eukaryotic membrane lipids. Molecular fossils often retain the diagnostic carbon skeleton of their biological precursors and may endure for hundreds of millions of years 
enclosed in sedimentary rocks. Eukaryotic membranes contain a suite of distinct sterols with 26 to 30 carbon atoms. In the fossil record, these sterols are often preserved in the form of $\mathrm{C}_{26}$ to $\mathrm{C}_{30}$ hydrocarbon steranes, and the relative concentration of these hydrocarbons is commonly determined by the most abundant eukaryotes in a community. In the Phanerozoic, the relative abundance of sterane homologues is characterized by a roughly gradual change from the Cambrian to the Tertiary, a pattern that reflects the succession of dominant primary producers in the oceans (Knoll et al. 2007). However, from the Archaean to the midNeoproterozoic, the distribution of different sterane homologues shows no patterns with age or depositional facies and is generally indistinguishable from any particular period in the Phanerozoic. This distribution is in conflict with the gradual and slow appearance of major eukaryotic clades in the body fossil record.

The conflict between the records of micro- and molecular fossil may, in principle, have a biological or preservational explanation. However, using new methodologies that can detect traces of younger contaminants in complex mixtures of indigenous biomarkers (Brocks et al. 2008; Brocks \& Hope 2008), we show that a great proportion of the Precambrian biomarker record is compromised by anthropogenic petroleum products. A reappraisal of biomarkers from 2.7 to $0.5 \mathrm{Ga}$ old sedimentary sequences under strict exclusion of younger contaminants shows that steranes in the Precambrian are generally rarely detected and, if present, very distinct from the Phanerozoic. Although the record of sedimentary sequences with demonstrably indigenous steranes is exceedingly patchy, a new pattern of sterane evolution emerges that is broadly consistent with microfossil evidence.

\section{References}

Brocks, J. J.; Grosjean, E. \& Logan, G. A. 2008. Assessing biomarker syngeneity using branched alkanes with quaternary carbon (BAQCs) and other plastic contaminants. Geochimica et Cosmochimica, Acta 72: 871-888.

Brocks, J. J. \& Hope, J. M. 2008. Contamination-free biomarker analysis of shales using oxidative microwave digestion. Australian Organic Geochemistry Conference.

Butterfield, N. J. 2004. A vaucheriacean alga from the middle Neoproterozoic of Spitsbergen: implications for the evolution of Proterozoic eukaryotes and the Cambrian explosion. Paleobiology 30: 231-252.

Butterfield, N. J.; Knoll, A. H. \& Swett, K. 1990. A bangiophyte red alga from the Proterozoic of arctic Canada. Science 250: 104-107.

Butterfield, N. J.; Knoll, A. H. \& Swett, K. 1994. Paleobiology of the Neoproterozoic Svanbergfjellet Formation, Spitsbergen. Fossils and Strata 34: 1-84.

Javaux, E.; Knoll, A. H. \& Walter, M. R. 2001. Morphological and ecological complexity in early eukaryotic ecosystems. Nature 412: 66-69.

Knoll, A. H. 1994. Proterozoic and early Cambrian protists: evidence for accelerating evolutionary tempo. Proceedings of the National Academy of Sciences of the United States of America 91: 6743-6750.

Knoll, A. H.; Javaux, E.; Hewitt, D. \& Cohen, P. 2006. Eukaryotic organisms in Proterozoic oceans. Journal Philosophical Transactions of the Royal Society (B: Biological Sciences) 361: 1023-1038. 
Knoll, A. H.; Summons, R.; Waldbauer, J. R. \& Zumberge, J. E. 2007. The geological succession of primary producers in the oceans. In: Falkowski, P. \& Knoll, A. H. (eds.): The Evolution of Primary Producers in the Sea. pp. 133-163; Burlington (Elsevier).

Porter, S. M. \& Knoll, H. 2000. Testate amoebae in the Neoproterozoic Era: evidence from vaseshaped microfossils in the Chuar Group, Grand Canyon. Paleobiology 26: 360-385.

Xiao, S.; Zhang, Y. \& Knoll, A. H. 1998. Three-dimensional preservation of algae and animal embryos in a Neoproterozoic phosphorite. Nature 391: 553-558.

\section{An Emerging Framework for Understanding Marine Stromatolite Formation [keynote]}

Alan W. Decho ${ }^{1}$, Peter T. Visscher ${ }^{2}$, Olivier Braissant ${ }^{2}$, Christophe Dupraz $^{2}$, R. Sean Norman ${ }^{1}$, R. Pamela Reid ${ }^{3} \&$ John F. Stolz ${ }^{4}$

${ }^{1}$ Department of Environmental Health Sciences, The Arnold School of Public Health, University of South Carolina, Columbia, USA; E-mail: awdecho@gwm.sc.edu

${ }^{2}$ Center for Integrative GeoSciences, University of Connecticut, Storrs, CT, US A; E-mail: pieter.visscher@uconn.edu,olivier.braissant@gmail.com\&christophe.dupraz@uconn.edu

${ }^{3}$ Rosenstiel School of Marine and Atmospheric Science, Division of Marine Geology and Geophysics, University of. Miami, Florida, FL, USA; E-mail:pried@rsmas.miami.edu

${ }^{4}$ Department of Biological Sciences, Duquesne University, Pittsburgh, PA, USA; E-mail:stol_@duq.edu

The microbial mats of marine stromatolites represent a three-billion-year old ecosystem that has persisted and adapted to environmental changes through geological time. We have studied modern marine stromatolites at Highborne Cay, Bahamas for $10+$ years to attempt to understand geological and microbiogeochemical mechanisms involved in their formation. Stromatolite layers are formed by microbial mats at the surface. Five major prokaryote functional groups (cyanobacteria, aerobes, fermenters, sulfate-reducers (SRM), and sulfur oxidizers), archaea, (and occasionally eukaryotes) that live in microspatial proximity The mats form three distinct microbial communities (termed Type 1, 2, 3) that have drastically different phenotypic, microbial and physical characteristics. The repeated cycling of these three communities, together, form the stromatolite macrostructure and repeated layering (i. e. micritic laminae) that are the hallmark of stromatolites. Extracellular polymeric secretions (EPS) provide an architectural foundation for spatially-structured assemblages in three dimensions. Additionally, EPS exhibit very different roles and properties in the three communities. In Type 1 communities, cyanobacteria produce EPS that are highly-adhesive. This facilitates accretion of ooids, and upward growth of the mat. Precipitation of $\mathrm{CaCO}_{3}$ is largely inhibited within Type 1 EPS due to efficient complexation of $\mathrm{Ca}^{2+}$ ions. In Type 2 communities, dramatic microspatial arrangements of cells occur, as detectable by FISH/confocal. EPS form a dense (non-sticky) gel that likely slows diffusion, and enhances the 
formation of sharp geochemical gradients. A thin horizontal horizon of both crystalline and amorphous precipitates forms within the EPS matrix, and is closely related to activities of SRM. Steric controls of functional groups on EPS, acting as precipitation nuclei, result in localized and controlled precipitation of $\mathrm{CaCO}_{3}$. Type 3 communities are characterized by microboring of ooids by endolithic cyanobacteria, and the formation of thick micritized laminae. Much of the EPS is inter-mixed with organics derived from ooids, and contributes to the formation of the micritic precipitate.

Recently, chemical signaling (i. e. quorum sensing (QS)) has been determined in Type 2 mats. QS coordinates group activities among bacteria, and may enhance the development of efficient consortia and the observed tight coupling of elemental cycling within Type 2 mats. Diel cycles in mats, engineered by net changes in photosynthesis and respiration, result in strong shifts in $\mathrm{pH}(6.5-9.0)$ over a $24 \mathrm{~h}$ period. Alkaline conditions (i. e. > pH 8.0) appear to restrict the activities of certain signals to night-time, and hence the resulting gene expression and metabolic activities of bacteria. We propose that the QS process may have evolved relatively early in the evolution of life, and that the ancient periodicity of photosynthesis/ respiration in mats drives a mechanism for diel changes in the activity of certain QS-autoinducers, and hence bacterial activities mediated through QS.

Finally, the stromatolite system has provided an initial look into ecological mechanisms that may guide bacterial interactions, for which there is very limited information. Our data currently support the idea that the repeated cycling of Type 1,2 , and 3 communities in stromatolites represent 'alternate stable states.' Alternate state communities are resistant to small perturbations, but will periodically shift to a different alternate state in response to a major disturbance. The ecological mechanisms that guide modern stromatolites in their relative resiliency and ability to adapt may be extended, by analogy, for approaching an understanding of fossil forms.

\title{
Bacterial Taphonomy: Micro-biosphere to Lithosphere [keynote]
}

\author{
F. Grant Ferris
}

Department of Geology, University of Toronto, Toronto, Ontario, Canada; E-mail: grant.ferris@utoronto.ca

The oldest well preserved microfossils on Earth are considered generally to be of bacterial (i. e., prokaryotic) origin. A common perception is that incorporation of Precambrian bacteria into the fossil record was fostered in part from mineral precipitation in association with the external cell wall and extracellular polymers of individual living cells. There are many modern examples of mineral formation on 
bacteria including carbonates, sulfides, oxides, and silicates; however, the formation of mineral precipitates alone on bacterial cell surfaces does not guarantee structural preservation. Among the different types of minerals that accrete on bacteria, few develop in a manner that is conducive to preserving cell morphology. These are typically phases that precipitate initially as nanoparticulate crystallites like amorphous silica or hydrous ferric oxides. Moreover, the abiotic coarsening of such minerals by orientated attachment of adjacent crystallites is inhibited by their physicochemical association with bacterial surfaces. This ensures that the organic remains of cells become coated with a fine-grained mineral covering that resists growth into more massive crystals. By way of contrast, other minerals like calcite tend to grow into larger crystalline forms that entomb bacterial cells without faithful preservation of cell structure. Further taphonomic constraints for cellular preservation of bacteria as microfossils include patchiness of cell surface mineralization (i. e., extent of mineral coating), degree to which cells are degraded, and mechanical strength of mineralized cellular remains. In the first instance, many bacterial cells evident in natural sediments fail to become mineralized. The precise reason for this is not clear, but probably related to cell surface chemistry. Second, all bacteria rely on autolytic enzymes to enable cell extension and growth. If these enzymes are left unchecked after death, cell rupture is apt to occur. Third, mineralized bacterial remains are subject to viscous fluid shear stress that can result in breakage into unrecognizable fragments at very low energy dissipation rates (i. e., even under quiescent conditions). This means that survival of structurally intact remains of bacteria depends strongly on rapid burial after cellular mineralization.

\title{
Geochemical and hydrological controls to annual lamination of tufa stromatolites in Japan [keynote]
}

\author{
Akihiro Kano ${ }^{1}$, Tatsuya Kawai ${ }^{2}$, Masako Hori ${ }^{3}$ \& Jun Matsuoka ${ }^{4}$ \\ ${ }^{1}$ Division of Evolution of Earth Environment, Graduate School of Social and Cultural Studies, Kyushu \\ University, Fukuoka, Japan; E-mail: kano@scs.kyushu-u.ac.jp \\ ${ }^{2}$ OD Scientific Technology, Marine Work Japan, Yokohama, Japan; E-mail: kawait@mwj.co.jp \\ ${ }^{3}$ Department of Earth and Planetary Systems Science, Graduate School of Science, Hiroshima University, \\ Higashi-hiroshima, Japan; E-mail: horizon@biroshima-u.ac.jp \\ ${ }^{4}$ Kochi Core Center, Marine Work Japan, Nankok.u, Japan; E-mail: matsuokaj@mwj.co.jp
}

Tufa is porous freshwater carbonate that is formed from spring water of meteoric origin in a limestone area (Ford \& Pedley 1996). It is deposited as fine-grained (typically several $\mu \mathrm{m}$ ) calcite crystals that nucleate and encrust on microbions living on the tufa surface. Fluvial tufa deposits in southwest Japan commonly develop 
stromatolitic lamination that consists of dense summer layers and porous winter layers. The annual rhythm of the lamination can be converted to precise time-scale of the tufas, which raises the potential as paleoclimatic archives (Andrews 2006). A study at Shirokawa (Ehime Prefecture) hypothesized that the lamination has been largely attributed to a seasonally variable inorganic precipitation rate of calcite (Kano et al. 2003) that is generally high in summer and low in winter. This seasonal pattern in precipitation rates is a common feature at many other tufa-depositing sites (Kawai et al. 2006). However, clearness of the lamination varies depending on sites, and the rule observed at Shirokawa was not always established in the other sites.

Here, we examined the rate-controlled hypothesis by using two quantitative data sources; 1) calcite packing-density (CPD) of measured by electron microprobe analyser (EPMA) for the portions segmented in monthly resolution, and 2) the precipitation rate of calcite (PWP rate) calculated from water chemistry. The results for four tufa-depositing sites in SW Japan show a positive correlation between CPD and PWP rate, but the correlation becomes less certain in one site where PWP rate was generally high (Shimokuraida, Okayama Prefecture; Fig. 1). In the temperature realm of SW Japan, tufas develop regular distinct seasonal change in CPD when PWP rate is lower than $2.5\left(\times 10^{-10} \mathrm{M} / \mathrm{sec}^{\left.-\mathrm{cm}^{2}\right)}\right.$ that roughly corresponds to the Ca concentration less than $65 \mathrm{mg} / \mathrm{L}$. On the other hand, even with high PWP rate, the CPD of tufa deposits rarely exceeds $65 \%$, owing to pore space between fine-grained calcite crystals and to openings derived from decomposed cyanobacteria and other microorganisms. By increasing the Ca concentration to more than $65 \mathrm{mg} / \mathrm{L}$, the CPD often attains an upper limit and becomes insensitive to seasonal changes in the PWP rate. Therefore, seasonal variation in CPD at sites with a higher $\mathrm{Ca}$ content are unclear, as observed in two examples from tropical islands in southern Japan and in one locality in temperate climate. Thus, the ratecontrolled hypothesis was revised.

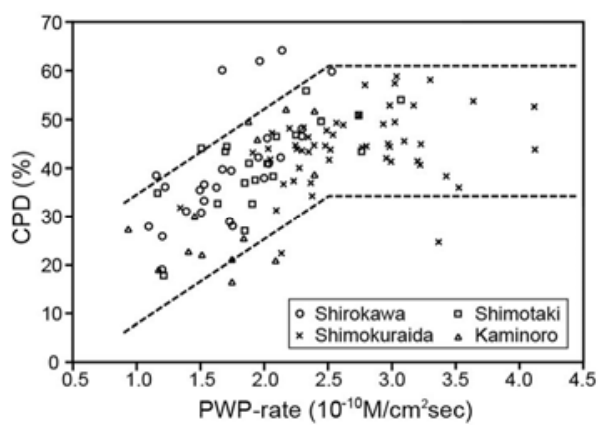

Fig. 1. Cross plot of CPD and PWP rate. The dashed lines show the range of the general trend. CPD increases with PWP rates of $<2.5 \times 10^{-10} \mathrm{M} / \mathrm{cm}^{2} \mathrm{sec}$, but appears independent of the PWP rate at higher rate values.

The flow rate and microbial density on the tufa surface are subordinate factors with respect to the CPD. It is generally considered that high flow rate enhances calcite precipitation by activated diffusion at the tufa surface (Dreybrodt \& Buh- 
mann 1991), and this was supported by a weak but positive correlation between the CPD and the flow rate observed at the Shimokuraida site (Fig. 2).

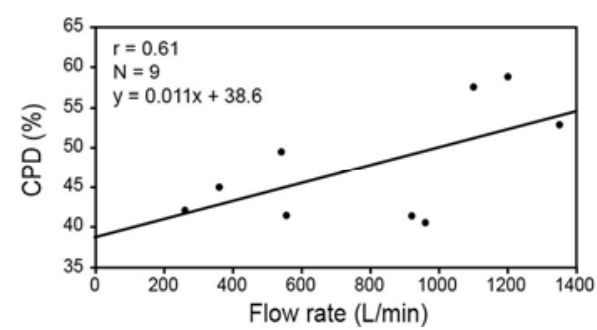

Fig. 2. Cross plots of CPD and flow rate in the range of PWP rate $=3.0 \sim 3.2 \times 10^{-}$ ${ }^{10} \mathrm{M} / \mathrm{cm}^{2} \mathrm{sec}$. All data are from Shimokuraida.

In Japanese Islands, frequent rainfall from the summer Asian monsoon increases flow rate that generally form densely-calcified layer. Seasonal change in flow rate often enhances the porous/dense contrast of annual lamination in SW Japan. The cyanobacterial biofilms on a tufa surface tend to be thick in winter and thin in summer. This seasonal pattern is unlikely controlled by physiology of cyanobacteria that principally thrive on sunlight and prefer warmer water temperature. It is more likely that activated calcite deposition inhibits the growth of cyanobacteria and results in thinly developed biofilm in summer.

Acknowledgements: We thank Hayami Ishisako and Yasuhiro Shibata for EPMA analysis and thin-section preparation. This study was supported by Japan Society for the Promotion of Science and Japanese Ministry of Education and Science.

\section{References}

Andrews, J. E. 2006. Palaeoclimatic records from stable isotopes in riverine tufas: Synthesis and review. Earth-Science Reviews 75: 85-104.

Dreybrodt, W. \& Buhmann, D. 1991. A mass transfer model for dissolution and precipitation of calcite from solutions in turbulent motion. Chemical Geology 90: 107-122.

Ford, T. D. \& Pedley, H. M. 1996. A review of tufa and travertine deposits of the world. Earth-Science Reviews 41: 117-175.

Kano, A.; Matsuoka, J.; Kojo, T. \& Fujii, H. 2003. Origin of annual laminations in tufa deposits, southwest Japan. Palaeogeography, Palaeoclimatology, Palaeoecology 191: 243-262.

Kawai, T.; Kano, A.; Matsuoka, J. \& Ihara, T. 2006. Seasonal variation in water chemistry and depositional processes in a tufa-bearing stream in SW-Japan, based on 5 years of monthly observations. Chemical Geology 232: 33-53. 


\title{
Deep Biosphere: what's going on there and how? [keynote]
}

Kenji Kato

Department of Geosciences, Shizuoka University, Japan; E-mail: sk.kato@ipc.shizuoka.ac.jp

Bacteria and Archaea, pioneer of life, have extended their distribution on and "in" earth through evolving their energy machinery and their equipments to adapt unfamiliar environments. Their evolutionary tracks vividly remain in subsurface. On the other side, a phrase on bacterial distribution given over 70 years ago as "Everything is everywhere, the environment selects" (Baas-Becking 1934) clearly stated distribution of prokaryotes. However, their distribution in subsurface has not yet revealed until recently, though variety of subsurface environments seems to select prokaryotes sharply at individual site. Three sketches on microbial ecology in subsurface environments show us some aspects of bacterial ecology and evolution in subsurface: First sketch: Genes remain, but who are/might be active?; Second sketch: Geological setting constrains bacterial distribution; Third sketch: Methanogenesis in insitu or not.

\section{Unexpected functional and phylogenetic diversity in anaerobic methane oxidising microbial communities [keynote]}

\author{
Martin Krüger ${ }^{1}$, Richard Seifert ${ }^{2}$, Hans-H. Richnow ${ }^{3} \&$ Michael Friedrich ${ }^{4}$ \\ ${ }^{1}$ Federal Institute for Geosciences and Resources (BGR), Hannover, Germany; E-mail: \\ Martin.Krueger@bgr.de \\ ${ }^{2}$ Institute of Biogeochemistry and Marine Chemistry, University of Hamburg, Hamburg, Germany; \\ E-mail: richard.seifert@_zmaw.de \\ ${ }^{3}$ Helmboltz Centre for Environmental Research UFZ, Leipzig, Germany; E-mail: bans.richnow@ufz.de \\ ${ }^{4}$ Max Planck Institute for Terrestrial Microbiology, Marburg, Germany; E-mail:michael.friedrich@mpi- \\ marburg.mpg.de
}

The anaerobic oxidation of methane (AOM) is one of the most important sinks for the greenhouse gas methane in marine ecosystems, consuming more than $80 \%$ of the methane produced in marine sediments prior to their emission into the atomsphere. After the discovery of AOM approximately 40 years ago and its verification and localisation via geochemical evidence, the identification of the responsible microorganisms became possible. In addition to biogeochemical methods, newly developed molecular tools have provided deeper insights into the size and composition of AOM communities under different environmental regimes. Sediments of the Black Sea harbour consortia of anaerobically methane-oxidizing microorganisms in dense microbial mats, incrusted in large chimney structures consisting of 
carbonate precipitate. A number of convincing facts collected previously suggests that anaerobically methane-oxidizing Archaea (ANME) as well as deltaproteobacterial sulphate-reducing bacteria are the key players in anaerobic methane oxidation in Black Sea Mats: their presence has been shown by fluorescent-in-situ hybridization (FISH) with $16 \mathrm{~S}$ rRNA-targeting probes, lipid biomarkers have typical, low delta ${ }^{13} \mathrm{C}$ ratios in archaeal and bacterial lipids, a methyl coenzyme $\mathrm{M}$ reductase like protein was purified from the mat, and mat samples exhibit anaerobic methane oxidation activity. Here, we show that the diversity of Bacteria in both, pink and black mat samples, is larger than previously known. T-RFLP analysis of $16 \mathrm{~S}$ rRNA and $16 \mathrm{~S}$ rRNA genes and cloning and sequencing of randomly selected clones revealed the presence of taxa hitherto unknown to be present in anaerobically methane-oxidizing consortia. Besides the previously known delta-proteobacterial sulphate reducers, clones fell into 7 and 5 different phyla in pink and black coloured mats, respectively. Our findings suggest that the turnover of carbon in anaerobically methane-oxidizing communities might involve a larger diversity of microorganisms than was previously assumed.

Furthermore, the development of revolutionary technical approaches, like Proteomic-SIP or FISH-SIMS, combining the identification of the microorganisms and of metabolic traits revealed novel physiological traits of AOM communities. Examples are the usage of different nitrogen sources, including nitrogen fixation, the origin of cell carbon and kinetic aspects. However, only the very recent establishment of in vitro systems and the discovery of samples naturally enriched in AOM biomass enabled laboratory studies of the environmental regulation and enzymatic mechanism of AOM. We could isolate and identify two abundant enzymes involved in the sulfate reduction pathway, ATP sulfurylase (ATPS) and APS reductase $\beta$-subunit (AprB). Amino acid sequence comparison revealed higher similarities of the N-terminal amino acid sequences to bacterial ATPS and AprB than to archaeal ones. Additionally, activity of both enzymes could be shown in the mat extract, with turnover rates sufficient to match methane dependent sulfate reduction. Although both proteins could so far not be directly attributed to AOM associated sulfate reducing bacteria, evidence increases that AOM in the Black Sea mats is mediated by the syntrophic association of ANME and SRB. 


\section{Two Years in the Life of a Stromatolite, Highborne Cay Bahamas: Assessing the Role of Algal Eukaryotes in Stromatolite Formation [keynote]}

R. Pamela Reid ${ }^{1}$, Emily Bowlin ${ }^{1}$, Ana Patricia Gaspar ${ }^{1}$, Miriam S. Andres $^{2}$, Ian G. Macintyre $^{3} \&$ John F. Stolz 4

${ }^{1}$ Rosenstiel School of Marine and Atmospheric Science, University of Miami, Miami, FL, USA; E-mail: preid@rsmas.miami.edu, e.bowlin@umiami.edußo apgaspar@rsmas.miami.edu

${ }^{2}$ Cheuron Energy Technology Company, San Ramon, CA, USA; E-mail:Miriam.Andres@chevron.com

${ }^{3}$ Smithsonian Institution, National Museum of Natural History, Department of Palaeobiology,

Washington, USA; E-mail:macintyre@si.edu

${ }^{4}$ Department of Biological Sciences, Duquesne University, Pittsburgh, PA, USA; E-mail:stol々@duq.edu

Modern stromaolites, such as those in Shark Bay Australia and Exuma Cays, Bahamas, are coarse grained, sandy structures that contrast with Precambrian stromatolites, which are typically micritic. Previous authors have suggested that this change in texture may be linked to an evolution in the composition of stromatolite-building communities: fine-grained Precambrian stromatolites result from precipitation in prokaryotic, cyanobacterial-dominated mats, whereas coarse-grained modern stromatolites form by trapping and binding of sand grains by microbial mats with abundant diatoms and other eukaryotic algae.

The role of diatoms and algae in the formation of open marine stromatolites in Exuma Cays Bahamas was assessed during a two year monitoring program at Highborne Cay Bahamas. Here, well-laminated and easily accessible stromatolite build-ups form in the back-reef of a $2.5 \mathrm{~km}$ algal-ridge fringing reef. Sedimentation, microbial mat communities and stromatolite accretion within the Highborne reef were monitored continuously for a two year period.

Migration of sand waves across the stromatolite reef is a major control on the distribution of microbial communities. Migrating sand waves bury and expose the reef episodically for periods of days, weeks, and months. Microbial mat composition and resultant stromatolite accretion reflect the duration of burial and exposure events.

Stromatolite surfaces may be colonized by purely prokaryotic mats, or by mixed communities of prokaryotes and eukaryotes. The prokaryotic mats are dominated by gliding filamentous cyanobacteria and are found chiefly on low-relief stromatolite ridges, which are buried and unburied on daily to weekly basis. Stromatolite accretion in the purely prokaryotic system is on the order of $1 \mathrm{~mm}$ per year.

Mixed prokaryotic-eukaryotic mat communities, consisting of stalked diatoms overlying filamentous cyanobacteria, are common on columnar stromatolites which experience month-long periods of burial and exposure. The diatom communities trap sediment, which is subsequently bound by upward migration of the 
underlying cyanobacteria. Stromatolite accretion by the mixed prokaryotic-eukaryotic community is on the order of $1 \mathrm{~cm}$ per year.

The Highborne Cay monitoring program indicates that cyanobacterial mats lacking diatoms are capable of trapping and binding sand-size particles and building modern marine stromatolites. Thus, the presence of sand grains in high relief columns in the fossil record cannot be considered evidence of algal communities. The addition of diatoms to cyanobacterial mats can increase stromatolite accretion rates by an order of magnitude, but the binding of diatom-accreted sand to form a wave resistant structure is accomplished by cyanobacterial communites. These results suggest that evolution of stromatolite-building communities to include eukaryotic algae does not explain the change through time in stromatolite texture.

\title{
Marrying stromatolite perspectives: $\mathbf{3 5 0 0}$ million year of history and a century of research [keynote]
}

\author{
Robert Riding \\ Department of Earth and Planetary Sciences, University of Tennessee, Knoxville, TN, USA; E-mail: \\ riding@cardiff.ac.uk
}

Stromatolites combine an extraordinarily long geological record with an unusual mixture of challenges. How they have formed and changed through time are key areas for research. Approaches to these questions hinge on stromatolite definition, and continuing lack of resolution of this central issue compounds the difficulties. Reflecting on the century since Ernst Kalkowsky introduced 'Stromatolithe', a pessimist might emphasize dogma and confusion. An optimist, on the other hand, could highlight significant advances that have laid the groundwork for many fruitful insights. Given their long history, the time period from which stromatolites are viewed is critically important. It is not difficult to regard many Phanerozoic stromatolites as essentially lithified microbial mats. In contrast, many Precambrian examples contain precipitated abiogenic crusts, both with and without microbial mats. The immediate challenge is to marry these dual abiogenic and biogenic perspectives of stromatolites resulting from a century of research.

Regular, even layering, common in Archaean stromatolites, probably reflects significant abiogenic precipitation, and early-mid Proterozoic stromatolites, including Conophyton, commonly show dark-light layers that appear to represent alternations of lithified mat and abiogenic crust. In contrast, Phanerozoic marine stromatolites are characterized by uneven fine-grained layers. These successive developments suggest decline in abiogenic precipitation and increase in lithified mat components through time. Presumably these in turn reflect changes in seawater chemistry and mat growth. Large - metric, even decametric - evenly layered Precambrian cones 
and domes lack present-day analogues. What factors determined their size and morphology, and promoted alternation of mat and abiogenic precipitate?

Abiogenic precipitation and mat lithification are dependent on carbonate saturation state with respect to $\mathrm{CaCO}_{3}$ minerals. Two important processes promoting carbonate precipitation in mats are sulphate reduction and photosynthesis. These could respectively be largely responsible for clotted/peloidal (spongiostrome) and tubiform (porostromate) microfabrics, and their inceptions could reflect changes in seawater composition. Palaeoproterozoic development of clotted/peloidal fabrics might reflect increased $\mathrm{SO}_{4}^{2-}$ level. Mesoproterozoic appearance of cyanobacterial sheath calcification could reflect development of $\mathrm{CO}_{2}$-concentrating mechanisms stimulated by decline in atmospheric $\mathrm{CO}_{2}$.

Stromatolite shape reflects original synoptic relief, determined by accretion rate relative to adjacent sediment. Low relative accretion rate results in low relief and complex shape; high relative accretion rate results in high relief and simple shape. In this view, mid-Proterozoic increase in morphotypic diversity, e. g., in branched stromatolites, is not a proxy for abundance. Instead it reflects lower synoptic relief due to reduced relative accretion rate. It could reflect reduced microbial growth and/or reduction in synsedimentary lithification.

Phanerozoic development of algal and metazoan reef builders inhibited microbial dome-column formation in favour of less regular reefal crusts, except during Mass Extinction aftermaths and in ecological refuges such as Shark Bay and Lee Stocking Island. Long-term overall decline in microbial carbonate abundance probably mainly reflects decline in seawater saturation state that slowed lithification and therefore accretion. Grazing may have been a subordinate factor so long as microbial mats were well lithified. Fluctuations in seawater saturation state are reflected by changes in microbial carbonate abundance and episodic development of dendrolite and thrombolite fabrics in the Cambrian-Early Ordovician, Late Devonian, and Permian-Triassic. Present-day high metazoan diversity and generally low saturation state result in scarcity of marine microbial carbonates. Diatoms transformed Cenozoic mat communities, significantly enhancing trapping ability, reflected in the formation of coarse-grained columns where stress inhibits metazoan overgrowth, as at Shark Bay and Lee Stocking Island. The coarse and crudely layered fabrics prominent in some of these columns are not closely comparable with most ancient stromatolites.

From this perspective, stromatolites emerge as abiogenic, biogenic, and combinations of the two. Their alterations in shape, size, fabric and abundance through time archive significant changes in atmospheric composition, seawater chemistry, mat evolution and biotic interaction. The key to ancient stromatolites lies in present-day examples. The key to present-day ones resides in the past. 


\title{
The deep-sea chemoautroph microbial world as experienced by the Mediterranean metazoans through time [keynote]
}

\author{
Marco Taviani
}

\section{ISMAR-CNR, Bologna, Italy; E-mail:marco.taviani@bo.ismar.cnr.it}

Complex deep-sea, chemoautrophically-fueled macrofaunal communities inhabit the Mediterranean basin since the Eocene at least. However, these communities underwent profound re-arrangements through time in response to a variety of interlinked factors that include type and availability of geofluids, evolving tectonic scenarios, seascape modifications, oceanographic and climatic vicissitudes. Oceantype communities characterized by giant lucinid (many species), modiolid mussel (e. g. ?Bathymodiolus), vesicomyid (including Calyptogena) and solemyid (Acharax) bivalves (cf. Fig. 1) together with specialized gastropods (e. g., Thalassonerita) and tubeworms, colonized the Mediterranean basin until the upper Miocene but did not survive the Messinian Salinity Crisis. Similar communities (deprived of giant lucinids) still occur at present associated with deep-water cold seeps (dwcs) in the Atlantic Ocean, i. e. offshore Congo and the Gulf of Mexico. The Pliocene Mediterranean dwcs communities are characterized by smaller lucinids (e.g. Lucinoma; cf. Fig. 1) and vesicomyids, and this basic motif extends into the Recent as documented by similar bivalves and tubeworms recorded from Eastern Mediterranean mud volcanoes and the Nile Fan, and the Alboran Sea. One puzzling occurrence is offered by the large solemyid Acharax (the gutless clam) whose distribution encompasses the Miocene and the Pliocene, but is apparently extinct in the Recent Mediterranean while still thriving in the adjacent Atlantic Ocean where inhabiting reducing bottom and cold seep sites in the Gulf of Cadiz. By large, the main nutritional strategy of Tertiary to Recent Mediterranean dwcs macrofauna is sulfur-based.

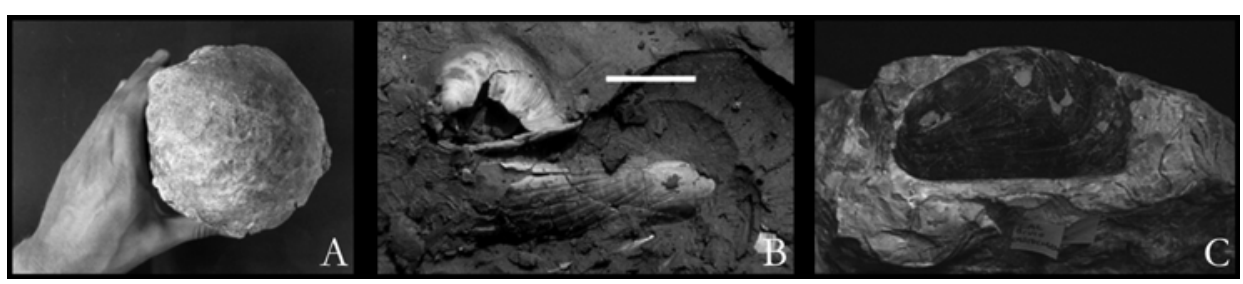

Fig. 1. Examples of chemosynthetic bivalves from the Mediterranean basin. (A) giant lucinid clam from the upper Miocene of the Romagna Apennine; (B) in situ Lucinoma (upper) and Acharax (lower) bivalves in Middle Pliocene reducing sediments of the Stirone river, Emilian Apennnine; (C) methanotrophic modiolid mussel (?Bathymodiolus) from the Tortonian of the Romagna Apennine.

In fact, the large majority of fossil and recent dwcs macrofaunal representatives are lucinids, vesicomyids and solemyids, known to host endobiotic sulphide-oxidizing bacteria in their tissues enabling their survival in oxygen poor, $\mathrm{H}_{2} \mathrm{~S}$-rich sediments. 
This general type of reducing environments is and was widespread in the deep Mediterranean basin explaining the high frequency of such types of dwcs macrofaunal communities. One notable exception is offered by some upper Miocene (mainly Tortonian) cold seep sites where the usual deep-water sulphurbased taxa cohabited with methanotrophic mussels (e. g.? Bathymodiolus) and other indicators of conspicuous hydrocarbon seepage on the seabottom (i. e.Thalassonerita). This peculiar condition was apparently confined at the peak of the Apennine orogeny and likely controlled by an important tectonic scenario conducive to methane-enriched defluidization.

\section{Microbial life in basaltic ocean crust [keynote]}

Ingunn $\mathrm{H}$. Thorseth

Centre for Geobiology and Department of Earth Science, University of Bergen, Norway; E-mail: Ingunn.Thorseth@geo.uib.no

Endolithic microbial communities have been documented in glassy basalt of young $(<1 \mathrm{Ma})$ seafloor lavas from the Arctic Mid-Ocean Ridge (AMOR) and Southeast Indian Ridge (SEIR), and of old ( $\sim 14-28 \mathrm{Ma}$ ) subseafloor basaltic rocks from north of the SEIR. For both the seafloor and subseafloor basalts low-temperature, oxygenated alteration conditions are indicated by secondary mineral phases. In the seafloor basalts numerous microbial cells of various morphologies associated with the altered glass rinds of most fractures and vesicles are easily observed by electron microscopy. Further enumerations by Q-PCR and fluorescence microscopy indicate $\sim 10^{6}$ cells $/ g$ glassy basalt, comprised mainly of Bacteria with only a minor fraction of Archaea present. The microbial cells become heavily encrusted by time and accumulate as hollow, fossilised cells within the alteration rinds. An organic carbon content of $\sim 0.9 \mathrm{wt} \%$ in the altered glass $\left(\delta^{13} \mathrm{C}_{\mathrm{org}}:-21.7 \%\right.$ ) thus derive from both living and fossilized, incompletely decomposed biomass. The microbial growth and biomineralization partially control the porosity and texture of the altered glass and thus likely also the chemical exchange between seafloor basalt and seawater. Pit marks in the glass resembling the morphology of attached cells, as well as pitting in fractures without microorganisms, indicate microbial as well as abiotic mediated glass dissolution.

In the glassy subseafloor basalts only fossilized cells are observed in fractures sealed by secondary mineral phases, demonstrating that the microbial activity continued as long as fluid circulation continued. Results from DNA sequencing analyses and culturing indicate that a diverse and indigenous microbial community of mostly Bacteria also are present in the old oceanic basalts, implying that postburial microbial activity mainly continues within new generations of fluid transporting fractures. The fewer phylogenetic groups detected in subseafloor basalts 
compared to seafloor basalts indicates a decrease in the biodiversity with aging and sediment burial of the crust. The five phylogenetic classes Gammaproteobacteria, Actinobacteria, Bacteroidetes, Chloroflexi, and Firmicutes are detected in both seafloor and subseafloor basalts, accounting for $77 \%$ of the total bacterial community in seafloor lavas and for $95 \%$ in the subseafloor basalts. The main differences observed were the high frequency of Gammaproteobacteria in subseafloor basalt, the restricted presence of Alphaproteobacteria in seafloor basalt, and Betaproteobacteria in subseafloor basalt. The results show that microbial communities inhabiting nonhydrothermal basaltic ocean crust participate in the cycling of iron and in production of methane from $\mathrm{H}_{2}$ and $\mathrm{CO}_{2}$. A major part of the microbial populations show, however, no close relation to previously known and characterised microorganisms. The phylogenetic and physiological diversity of microorganisms in non-hydrothermal oceanic basalt differ from those reported from hydrothermal regions of the ocean crust.

\section{Stromatolite morphology as an indictor of biogenicity for Earth's oldest fossils from the 3.5-3.4 Ga Pilbara Craton, Western Australia [keynote]}

Martin J. Van Kranendonk

Geological Survey of Western Australia, 100 Plain St., East Perth, Western Australia, 6004, Australia; E-mail: martin.vankranendonk@doir.wa.gov.au

\section{Introduction}

Stromatolites were recognised in 3.5-3.4 Ga rocks from the Pilbara Craton 30 years ago (Walter et al. 1980; Lowe 1980), but biogenicity is cast in doubt by recent studies of abiogenic features with gross similarity to biogenic forms (Grotzinger \& Rothman 1996) and new interpretations of geological settings that differ from original models (see below). This paper reviews the geological setting of Pilbara fossils and assesses stromatolite biogenicity, showing the critical nature of morphology in combination with geological context.

\section{Proposed fossil localities}

The 3.53-3.165 Ga East Pilbara Terrane (EPT), Pilbara Craton, formed through three unconformity-bound volcanic plume events, followed by rifting of the margins (Van Kranendonk et al. 2007). Strong claims for early life have been described from: (1) $3.48 \mathrm{Ga}$ Dresser Formation (diverse stromatolites, microfossils, highly negative $\delta^{13} \mathrm{C}$ on carbonaceous material, sulfur isotopes) (Walter et al. 1980; Ueno et al. 2004; Van Kranendonk 2006; Philippot et al. 2007); (2) 3.46 Ga Apex chert (microfossils, Laser-Raman spectrography) (Schopf 1993; Schopf et al. 2007); (3) $3.4 \mathrm{Ga}$ Strelley Pool Chert (diverse stromatolites, organic geochemistry) (Van 
Kranendonk 2006; Allwood et al. 2006; Marshall et al. 2007); (4) 3.24 Ga Sulphur Springs area (organic matter, $\delta^{13} \mathrm{C}=-30 \%$ on carbonaceous material, microfossils) (Duck et al. 2007). Previous models of the geological settings were: (1) quiet, shallow water, evaporative lagoon (Groves et al. 1981); (2) marine clastic sandstone (Schopf 1993); (3) sabkha to shallow marine environment (Lowe 1983); (4) sediment-hosted microbial community associated with active hydrothermal activity (Duck et al. 2007).

The Dresser Formation was deposited within an active volcanic caldera affected by growth faulting and hydrothermal fluid circulation (Van Kranendonk 2006; Nijman et al. 1998). Stromatolites at several stratigraphic levels have diverse forms: coniform, columnar, domical and wrinkly mats in shallow water marine carbonates, suggesting photoautrophy; domical and wrinkly laminated forms at hydrothermal vents, suggesting chemoautotrophy; wrinkly laminates parallel to hydrothermal vein walls, suggesting subsurface chemoautotrophs. Key morphological indicators of stromatolite biogenicity are coniform shapes in undeformed sediment (Fig. 1A), microbially bound ripples (Fig. 1B), and draped sedimentary wedges off stromatolites (Van Kranendonk 2006). Biogenicity is supported by highly negative $\delta^{13} \mathrm{C}$ kerogen in hydrothermal veins and by sulphur isotope data (Ueno et al. 2004; Philippot et al. 2007).

Microfossils were identified in samples from the Apex Chert collected without proper geological context (Schopf 1993). Recent mapping revealed their origin in a hydrothermal breccia vein, not in sandstone as previously described, and detailed petrography showed more complex morphologies that cast doubt on biogenicity (Van Kranendonk 2006; Brasier et al. 2002). However, morphology continues to be a compelling indicator of biogenicity (Schopf et al. 2007) and microfossils could occur in a subterranean hydrothermal setting in three ways (Van Kranendonk 2006).

- Fig. 1. Key morphological indicators of biogenicity: A) bedding plane view of coniform stromatolites in undeformed sediment; B) section through microbially bound sediment (finger at left); C) section through branching columnar stromatolite (height is $5 \mathrm{~cm}$ ); D) section through silicified coniform stromatolite flank, with onlapping sediment (arrows; bars are in centimetres); E) high-amplitude coniform stromatolite in carbonate, passing up through quiet water, high-energy (storm event) and quiet water (arrows) conditions; F) Thin section view of growth wall on columnar stromatolite (arrows), capped by transgressive sand bed (height of view $=2 \mathrm{~cm}$ ); G) Plane polarized light thin section view of clotty carbonaceous material in microbial mat in sandstone. A) and B) from 3.48 Ga Dresser Fm.; C)-G) from 3.4 Ga Strelley Pool Chert) (Van Kranendonk et al. 2003; Van Kranendonk 2006, 2007). 

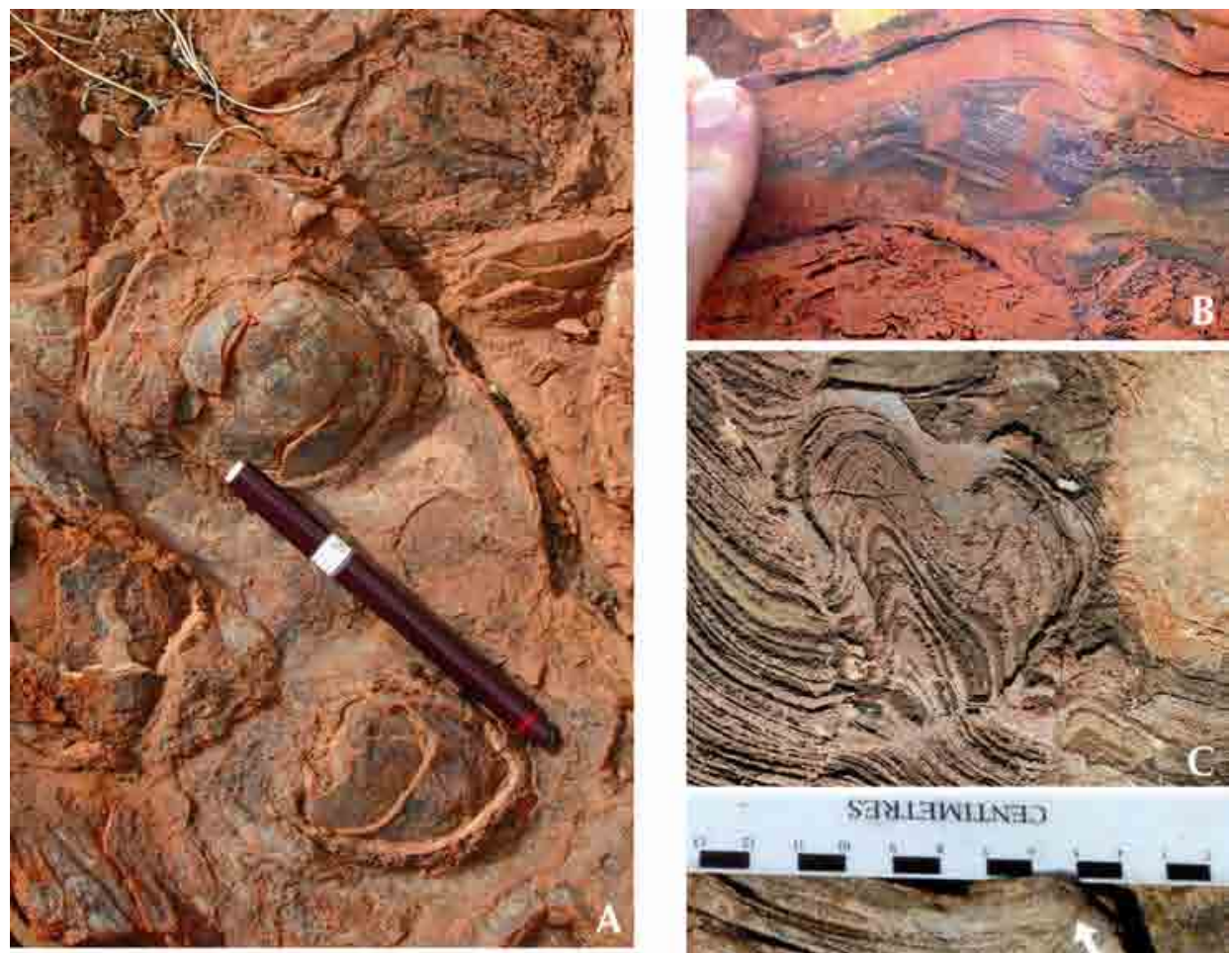

SaMIIWHINa)
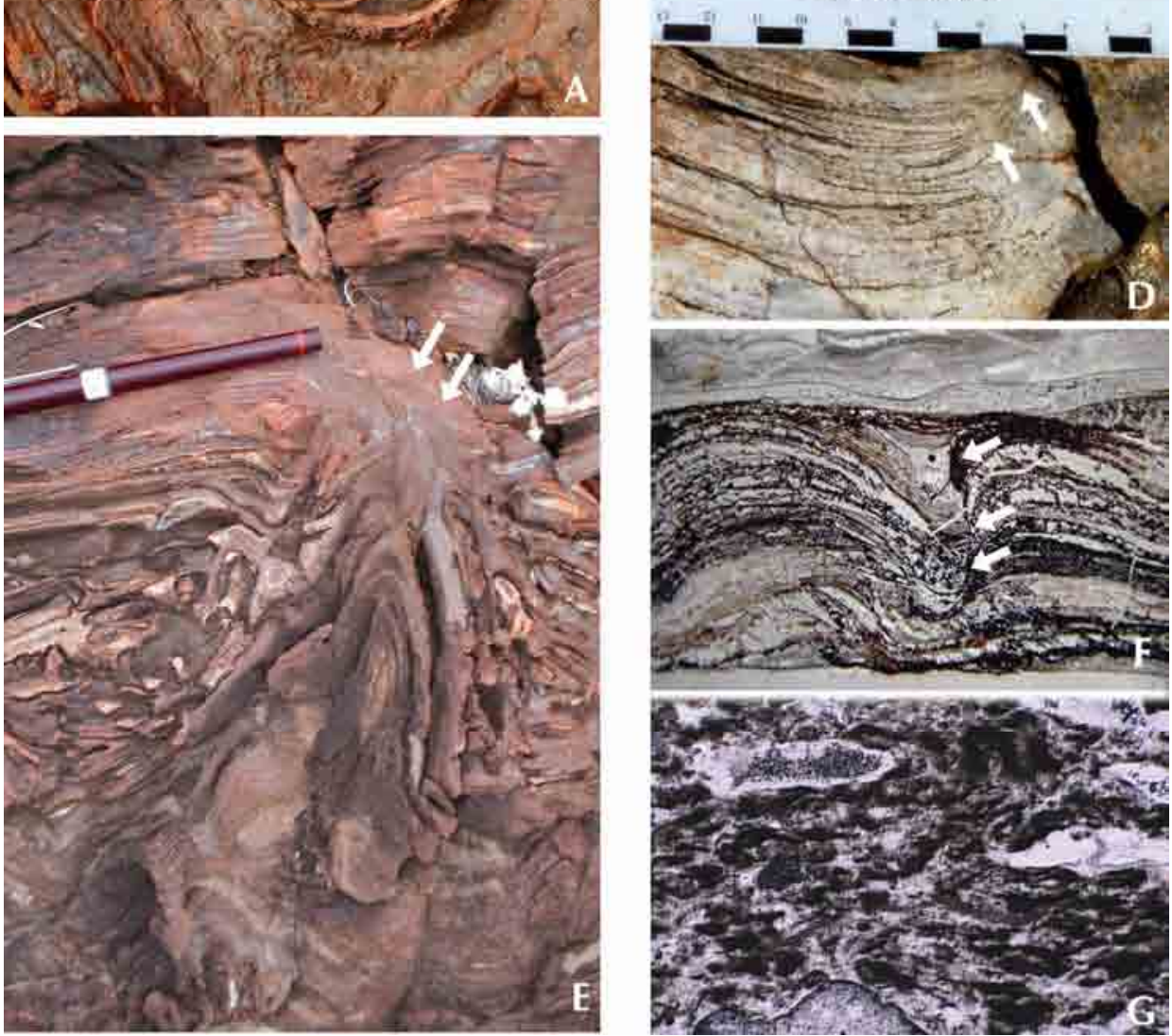
The Strelley Pool Chert was deposited during a marine transgression from subaerial to fully marine conditions (Van Kranendonk 2006; Allwood et al. 2006; Van Kranendonk 2007). Members include: basal fluviatile to beach and nearshore clastic deposits; a middle shallow marine, to supratidal, carbonate platform; disconformably overlying submarine alluvial fans. Stromatolites have unique morphologies in shallow marine (coniform and branching columnar forms) and supratidal carbonates (low amplitude domes and wrinkly mats), and in clastic rocks (clotty organic material) (Van Kranendonk 2007). Key morphological indicators of biogenicity include: complex, incipiently branching coniform stromatolites, branching columnar forms (Fig. 1C), microbially bound ripples (as in Fig. 1A), along-strike biofacies variations, onlapping biostromes, onlapping sediment on stromatolites (Fig. 1D), stromatolite growth through high-energy events (Fig. 1E), growth walls on columnar forms (Fig. 1F), and clotty kerogen in degraded mats in sandstone (Fig. 1G) (Allwood et al. 2006; Van Kranendonk 2007). Biogenicity is supported by geochemical signatures of marine carbonate deposition and organic geochemistry (Marshall et al. 2007; Van Kranendonk et al. 2003).

Morphology is a key indicator of biogenicity in the Sulphur Springs area, through recognition of clasts of finely laminated, lenticular to banded organic matter (degraded stromatolite) in sandstone, and tubular to spheroidal microfossils (Duck et al. 2007).

\section{Summary}

Convergent lines of evidence from investigations of putative fossil assemblages from several distinct horizons in the EPT point to abundant and diverse microbial life on early Earth. A key indicator of biogenicity in all studied examples is morphology, but this must be set within a well constrained geological context.

\section{References}

Allwood, A. C.; Walter, M. R.; Kamber, B. S.; Marshall, C. P. \& Burch, I. W. 2006. Stromatolite reef from the Early Archaean era of Australia. Nature 441: 714-717.

Brasier, M. D.; Green, O. R.; Jephcoat, A. P.; Kleppe, A. K.; Van Kranendonk, M. J.; Lindsay, J.F.; Steele, A. \& Grassineau, N. 2002. Questioning the evidence for Earth's oldest fossils. Nature 416: 76-81.

Duck, L. J.; Glikson, M.; Golding, S. D. \& Webb, R. E. 2007. Microbial remains and other carbonaceous forms form the $3.24 \mathrm{Ga}$ Sulphur Springs black smoker deposit, Western Australia. Precambrian Research 154: 205-220.

Grotzinger, J. P. \& Rothman, D. H. 1996. An abiotic model for stromatolite morphogenesis. Nature 383: 423-425.

Groves, D. I.; Dunlop, J. S. R. \& Buick, R. 1981. An early habitat of life. Scientific American 245: 64-73.

Lowe, D. R. 1980. Stromatolites 3,400-Myr old from the Archaean of Western Australia. Nature 284: 441-443.

Lowe, D. R. 1983. Restricted shallow-water sedimentation of Early Archean stromatolitic and evaporitic strata of the Strelley Pool Chert, Pilbara Block, Western Australia. Precambrian Research 19: 239-283. 
Marshall, C. P.; Love, G. D.; Snape, C. E.; Hill, A. C.; Allwood, A. C.; Walter, M. R.; Van Kranendonk, M. J.; Bowden, S. A.; Sylva, S. P. \& Summons, R. E. 2007. Structural characterization of kerogen in $3.4 \mathrm{Ga}$ Archaean cherts from the Pilbara Craton, Western Australia. Precambrian Research 155 (1-2): 1-23.

Nijman, W.; De Bruin, K. \& Valkering, M. 1998. Growth fault control of early Archaean cherts, barite mounds, and chert-barite veins, North Pole Dome, Eastern Pilbara, Western Australia. Precambrian Research 88: 25-52.

Philippot, P.; Van Zuilen, M.; Lepot, K.; Thomazo, C.; Farquhar, J.\& Van Kranendonk, M. 2007. Early Archean microorganisms preferred elemental sulphur, not sulphate. Science 317: 1534-1537.

Schopf, J. W. 1993. Microfossils of the Early Archaean Apex Chert: new evidence of the antiquity of life. Science 260: 640-646.

Schopf, J. W.; Kudryavtsev., A. B.; Czaja, A. D. \& Tripathi, A. B. 2007. Evidence of Archean life: Stromatolites and microfossils. Precambrian Research 158: 141-155.

Ueno, Y.; Yoshioka, H.; Maruyama, S. \& Isozaki, Y. 2004. Carbon isotopes and petrography in $\sim 3.5 \mathrm{Ga}$ hydrothermal silica dykes in the North Pole area, Western Australia. Geochimica et Cosmochimica, Acta 68: 573-589.

Van Kranendonk, M. J. 2006. Volcanic degassing, hydrothermal circulation and the flourishing of early life on Earth: new evidence from the Warrawoona Group, Pilbara Craton, Western Australia. Earth-Science Reviews 74: 197-240.

Van Kranendonk, M. J. 2007. A review of the evidence for putative Paleoarchean life in the Pilbara Craton. In: Van Kranendonk, M. J.; Smithies, R. H. \& Bennet, V. (eds.): Earth's Oldest Rocks. Developments in Precambrian Geology 15: 855-896.

Van Kranendonk, M. J., Webb, G. E. \& Kamber, B. S. 2003. Geological and trace element evidence for a marine sedimentary environment of deposition and biogenicity of $3.45 \mathrm{Ga}$ stromatolitic carbonates in the Pilbara Craton, and support for a reducing Archean ocean. Geobiology 1 (2): 91108.

Van Kranendonk, M. J. et al. 2007. Secular tectonic evolution of Archaean continental crust: interplay between horizontal and vertical processes in the formation of the Pilbara Craton, Australia. Terra Nova 19 (1): 1-38.

Walter, M. R.; Buick, R. \& Dunlop, J. S. R. 1980. Stromatolites, 3,400-3,500 Myr old from the North Pole area, Western Australia. Nature 284: 443-445.

\title{
A stratiform stromatolite from 3.33 Ga-old biolaminated sediments in the Barberton Greenstone Belt, South Africa [keynote]
}

\author{
Frances Westall*
}

Centre de Biophysique Moléculaire-CNRS and Université d'Orléans, Rue Charles Sadron, 45071 Orléans, France; E-mail: frances.westall@cnrs-orleans.fr

* This work is supported by a consortium including: L. Lemelle (Univ. Lyon); A. Simionovici (Uiv. Grenoble); M. Salomé (ESRF-Grenoble); Y. Marrocchi, S. Mostefaoui, A. Meibom, F. Robert (Natural History Museum, Paris); G. Southam, L. LacLean, (Univ. Western Ontario), S. Wirick (NSLS, Brookhaven); J. Toporksi, A. Jauss (WITEC, Ulm)

Three-dimensional stromatolites are known from Early Archaean cherts in the Pilbara and Barberton greenstone belts (Lowe 1980; Walter et al. 1980; Byerly et al. 
1986; Hofmann et al. 1999; Allwood et al. 2006), although the biogenicity of these structures has been called into question (Lowe 1994). Stratiform stromatolites are even more difficult to interpret in these most ancient sediments but we describe a well-preserved, silicified, stratiform stromatolite that occurs in biolaminated, littoral environment sediments from the $3.33 \mathrm{Ga}$-old Josefsdal Chert (Westall et al. 2006) in the Barberton greenstone belt.

The 1- 7 $\mu \mathrm{m}$ thick microbial mat formed on a partially exposed sediment surface and, in its upper layers, is inter-layered with a suite of pseudomorph evaporite minerals including aragonite, gypsum, $\mathrm{Mg}$ calcite and a halide. The mat consists of an upper layer of heavily EPS-coated filaments, $0.25 \mu \mathrm{m}$ in thickness and several $10 \mathrm{~s} \mu \mathrm{m}$ in length, beneath which is a $0.5-3 \mu \mathrm{m}$ thick layer of reticular kerogen representing the degraded remains of microorganisms. Floating grains of quartz and trapped volcanic particles are common within the mat. The main body of the mat below the kerogen has been calcified. The presence of organic $S$ and and an Scontaining carbon molecule, thiophene, suggests that sulphate-reducing activity could have contributed to the calcification. The whole mat has been permineralised by hydrothermal silica and the turgid shapes of the filaments show that the mat was living when it was silicified. C isotope ratios of -22.7 to $-26.8 \%$ are consistent with photosynthetic activity.

This is the first report from Early Archaean cherts of a calcified microbial mat exhibiting photosynthetic-SRB consortium activity. Interestingly, UV radiation on the anoxic early Earth would have been very high (Westall et al. 2006) since there was no ozone layer. However, the Josefsdal microbial mat is coated with a very thick layer of EPS which would have served as protection and the organisms may have contained UV-protective pigments. The direct confirmation of photosynthetic activity at $3.33 \mathrm{Ga}$ supports the contention that photosynthesis had, indeed, appeared very early Earth's history.

\section{References}

Allwood, A. C.; Walter, M. R.; Kamber, B. S.; Marshall, C. P. \& Burch, I. W. 2006. Stromatolite reef from the Early Archaean era of Australia. Nature 441: 714-717.

Byerly, G. R.; Lowe, D. R. \& Walsh, M. M. 1986. Stromatolites from the 3300-3500 Myr Swaziland Supergroup, Barberton Mountain Land, South Africa. Nature 319: 489-491.

Hofmann, H. J.; Grey, K.; Hickman, A. H. \& Thorpe, R. I. 1999. Origin of 3.45 Ga coniform stromatolites in Warrawoona Group, Western Australia. Bulletin of the Geological Society of America 111: 1256-1256.

Lowe, D. R. 1980. Stromatolites 3,400-Myr old from the Archaean of Western Australia. Nature 284: 441-443.

Lowe, D. R. 1994. Abiological origin of described stromatolites older than 3.2 Ga. Geology 22: 287-390.

Walter, M. R.; Buick, R. \& Dunlop, J. S. R. 1980. Stromatolites, 3,400-3,500 Myr old from the North Pole area, Western Australia. Nature 284: 443-445.

Westall, F.; Ronde, C. E. J. de; Southam, G.; Grassineau, N.; Colas, M.; Cockell, C. \& Lammer, H. 2006. Implications of a 3.472-3.333 Ga-old subaerial microbial mat from the Barberton greenstone belt, South Africa for the UV environmental conditions on the early Earth. Philosophical Transactions of the Royal Society of London (B: Biological Sciences) 361: 1857-1875. 


\title{
Abstracts
}

\section{Lower Ordovician stromatolites from the Anhui Province of South China: their genesis and temporal significance [talk]}

\author{
Natsuko Adachi ${ }^{1}$, Yoichi Ezaki ${ }^{2} \&$ Jianbo Liu ${ }^{3}$ \\ ${ }^{1}$ Research Fellow of the JSPS/Miyagi University of Education, Miyagi, Japan; E-mail: \\ adachi@staff.miyak.yo-u.ac.jp \\ ${ }^{2}$ Department of Geosciences, Osaka City University, Osaka, Japan; E-mail: ezaki@sci.osaka-cu.ac.jp \\ ${ }^{3}$ School of Earth and Space Sciences, Peking University, Beijing, PR China; E-mail: jbliu@pku.edu.cn
}

The Cambrian through Early Ordovician was a lengthy interval when microbialites once again dominated after their decline from a peak in the Proterozoic (Riding 2006). This period corresponds to the initial stage of biodiversification that took place in the Ordovician. The Early Ordovician is thus a particularly intriguing time, before and after which a transition occurred from microbial- to metazoandominated reefs (Webby 2002). The present study describes stromatolite reefs from the Lower Ordovician Honghuayuan Formation (late Tremadocian-Floian) in Anhui Province, South China, in order to elucidate their genesis along with their temporal and geobiological significance.

Stromatolites characteristically develop within small, dome-shaped reefs and are ordinarily accompanied by lithistid and receptaculitid sponges. Individual stromatolites (10-30 cm high) exhibit nodular and columnar outer shapes with an obscure, laminar inner texture at a mesoscopic scale, and develop on bioclastic micrites and/or directly upon sponges as substrates. The laminae of stromatolites at a microscopic scale are produced by the irregularly repeated accumulation of Girvanella-rich layers without bioclasts, and thick micrite layers where Girvanella and bioclasts such as sponge spicules sporadically occur. These Girvanella-rich layers exhibit variously composed micritic textures as follows: (1) densely packed Girvanella; (2) micrites with Girvanella; (3) peloids, in and among which Girvanella is abundant; and (4) micrites with fenestral fabrics. Those textures grade into each other laterally, even within a single layer.

Girvanella accumulates as a main component of some laminae, implying that Girvanella itself played an important role in stromatolite formation. It is well known that Girvanella is derived from the complete calcification of cyanobacterial sheaths through photosynthesis, whereas bacterial degradation and incomplete calcification 
of the sheaths result in the formation of micrites such as peloids (Merz-Preiß 2002). A variety of micritic textures in the Girvanella-rich layers are considered to have originated from taphonomic and diagenetic variations within identical or similar filamentous microbial communities. In contrast, thick micritic layers include abundant bioclasts but sporadic Girvanella, and may have resulted mainly from the microbial (such as Girvanella) trapping and binding micrites with bioclasts. In summary, the stromatolites considered here are thought to have been constructed as follows: (1) microbes including Girvanella first encrusted the bioclastic micrites or dead sponges, then (2) stabilized these substrates, and (3) produced laminated microbialites, due to repeated changes in microbial activity (micrite precipitation or sediment trapping and/or binding), in concert with fluctuating ambient environments.

Girvanella-dominated micritic stromatolites are widespread in the Lower Ordovician. They are inferred to have been formed by the similar mechanisms noted above. Further prevalent characters that are unique to Lower Ordovician stromatolites are their co-occurrence with metazoans (e. g., lithistid sponges) within small reefs, although the metazoans were still low in diversity. Such Lower Ordovician reefs show a marked contrast with the subsequent shallow-marine reefs of the Middle to Late Ordovician, when skeletal metazoans such as stromatoporoids and corals flourished and stromatolites declined conspicuously. Lower Ordovician stromatolites thus elucidate the interrelationship between microbes and metazoans in the formation of age-specific reefs, as well as providing insights into the causes of the shift from microbial- to skeletal-dominated reefs.

\section{References}

Merz-Preiß, M. 2000. Calcification in cyanobacteria. In: Riding, R. E., Awramik, S. M. (eds.): Microbial Sediments: 50-56; Berlin (Springer).

Riding, R. 2006. Microbial carbonate abundance compared with fluctuations in metazoan diversity over geological time. Sedimentary Geology 185 (3-4): 229-238.

Webby, B. D. 2002. Patterns of Ordovician reef development. In: Kiessling, W., Flügel, E., Golonka, J. (eds.): Phanerozoic reef patterns. SEPM, Special Publication 72: 129-179.

\section{A numerical model calculating the $\mathrm{CaCO}_{3}$ saturation state in cyano- bacterial mats [talk]}

Giovanni Aloisi

Leibniz Institute for Marine Sciences (Ifm-Geomar), Wischhofstrasse, 1-3, 24148, Kiel, Germany;

E-mail:galoisi@ifm-geomar.de

A numerical model was developed which calculates the $\mathrm{CaCO}_{3}$ saturation state $\left(\Omega_{\mathrm{CaCO} 3}\right)$ in cyanobacterial mats as it is influenced by biogeochemical processes and 
molecular diffusion of dissolved species. The aim is to understand controls on $\Omega$ $\mathrm{CaCO}_{3}$ - which is positively correlated to the rate of $\mathrm{CaCO}_{3}$ precipitation - and thus investigate conditions which favour the calcification of cyanobacterial mats. The processes considered are: cyanobacterial photosynthesis, aerobic respiration, sulphate reduction, sulphide oxidation, $\mathrm{Ca}^{2+}$-binding on - and release from - organic substances, carbon concentration by cyanobacteria and $\mathrm{CaCO}_{3}$ precipitation. A biogeochemical dataset (Visscher et al. 1998) obtained from modern marine calcifying cyanobacterial mats at Highborne Cay (Bahamas) is used to constrain the model. Model results suggest that while photosynthetic $\mathrm{CO}_{2}$ consumption increases $\Omega_{\mathrm{CaCO}}$ significantly in Highborne Cay mats, sulphate reduction has a small and opposite effect on mat $\Omega_{\mathrm{CaCO}}$ because it is coupled to $\mathrm{H}_{2} \mathrm{~S}$ oxidation with $\mathrm{O}_{2}$. Furthermore, $\mathrm{Ca}^{2+}$-binding to and release from organic substances has a negligible effect on $\Omega_{\mathrm{CaCO}}$ in Highborne Cay mats because of efficient diffusive exchange of $\mathrm{Ca}^{2+}$ with bottom waters.

A large number of model runs corresponding to a wide range of states of the dissolved inorganic carbonate (DIC) system show that the magnitude of the $\Omega_{\mathrm{CaCO}}$ increase is proportional to DIC in DIC-limited waters (DIC $<3-10 \mathrm{mM}$ ), is proportional to $\mathrm{pH}$ when ambient water DIC is not limiting and always proportional to the concentration of $\mathrm{Ca}^{2+}$ in ambient waters. With oceanic $\mathrm{Ca}^{2+}$ concentrations greater than a few $\mathrm{mM}$, an appreciable increase in $\Omega_{\mathrm{CaCO}}$ occurs in mats under a wide range of environmental and biological conditions, including atomspheric $\mathrm{pCO}_{2}$ levels between present atmospheric level $\left(\mathrm{PAL}=10^{\wedge}-3.5 \mathrm{~atm}\right)$ and 50 PAL, temperature between 15 and $41^{\circ} \mathrm{C}$, salinity between 35 and $48 \%$, oceanic sulphate between 0 and $28.9 \mathrm{mM}$, oceanic $\mathrm{O}_{2}$ between 0 and $200 \mu \mathrm{M}$, solar luminosity between present levels and those at $2.8 \mathrm{Gyr}$ ago and presence/absence of a carbon concentrating mechanism in cyanobacteria. These results suggest that cyanobacterial photosynthesis influenced mat $\Omega_{\mathrm{CaCO}}$ throughout Earth's history. With the involvement of microbial surfaces and extracellular polymeric substaces (EPS) in carbonate nucleation (Dupraz \& Visscher 2005) (an aspect not addresses in this model study), these two processes emerge as fundamental controls of cyanobacterial mat calcification throughout Earth's history.

\section{References}

Dupraz, C. \& Visscher, P. T. 2005. Microbial lithification in marine stromatolites and hypersaline mats. Trends in Microbiology 13 (9): 429-438.

Visscher, P. T.; Reid, R. P.; Bebout, B. M.; Hoeft, S. E.; Macintyre, I. G. \& Thompson, J. A. [jr.] 1998. Formation of lithified micritic laminae in modern marine stromatolites (Bahamas): The role of sulphur cycling. American Mineralogist 83: 1482-1493. 


\section{Phosphorite laminites off Peru - products of microbial activity [talk]}

Esther T. Arning ${ }^{1}$, Daniel Birgel1, Benjamin Brunner², Andreas Lückge ${ }^{3}$ \& Jörn Peckmann ${ }^{1}$

'MARUM, Universität Bremen, Bremen, Germany; E-mail: earning@uni-bremen.de,dbirgel@unibremen.de@seckmann@uni-bremen.de

${ }^{2}$ Max-Planck-Institut für Marine Mikrobiologie, Bremen, Germany; E-mail:bbrunner@mpi-bremen.de

${ }^{3}$ Bundesanstalt für Geowissenschaften und Robstoffe (BGR), Hannover, Germany; E-mail: andreas.lweckge@bgr.de

The burial of phosphorus and the formation of phosphorites (phosphogenesis) in marine sediments represent an important sink in the global phosphorus cycle. Today, neither the source of phosphate of massive phosphorite deposits nor the importance and function of microorganisms in phosphogenesis is known with certainty. To elucidate this further, we carried out geochemical and petrographic analyses on phosphorite crusts of the Peruvian upwelling region at $10^{\circ} \mathrm{S} / 79^{\circ} \mathrm{W}$. This study provides new insight into an environment where phosphorite formation occurs in association with upwelling.

Peruvian phosphorites predominantly consist of a reworked and transported phosphoooid facies and later authigenic phosphatic laminite. Phosphatic laminites consist of light brown, fluorescent laminae, dark non-fluorescent laminae, and irregular light grey, strongly fluorescent laminae and lenses. The latter are associated with abundant metal sulfides.

Geochemical analyses of the phosphatic laminite show strong enrichments of chalcophilic elements $(\mathrm{Fe}, \mathrm{Zn}, \mathrm{Cr}, \mathrm{Cu}, \mathrm{Ni}$ ) and sulfur in contrast to the phosphorooid facies. High resolution element measurements, using Laser-ICP-MS, reveal enrichment of chalcophilic elements in sulfidic laminae. Microprobe analyses display the presence of sphalerite layers as well as abundant pyrite. This coincides with the occurrence of molecular fossils of sulfate-reducing bacteria in the phosphorites. Low sulfur isotope ratios of pyrite within the laminite $\left(\delta^{34} S\right.$ around $-30 \%$ ) corroborate the impact of bacterial sulfate reduction. The combination of geochemical and petrographic results elucidates that bacterial sulfate reduction is a key process in the formation of authigenic phosphorite laminites from the upwelling region off Peru. 


\title{
Increasing size and abundance of microbialites (oncolites) in connection with the $\mathrm{K} / \mathrm{T}$ boundary in non-marine environments from the South Pyrenean Basin (Iberian Peninsula) [poster]
}

\author{
Humberto Astibia ${ }^{1}$, Nieves López-Martínez ${ }^{2}$, Javier Elorza ${ }^{3} \&$ Enric Vicens ${ }^{4}$ \\ ${ }^{1}$ Departamento de Estratigrafía y Paleontología, Facultad de Ciencia y Tecnología, Universidad del País \\ Vasco/Euskal Herriko Unibertsitatea, Bilbao,Spain; E-mail: bumberto.astibia@ebu.es \\ ${ }^{2}$ Departamento de Paleontología, Facultad de Ciencias Geológicas, Universidad Complutense de Madrid, \\ Madrid, Spain; E-mail: lopezman@geo.ucm.es \\ ${ }^{3}$ Departamento de Mineralogía y Petrología, Facultad de Ciencia y Tecnología, Universidad del País \\ Vasco, Bilbao,Spain; E-mail:josejavier.elorza@ehu.es \\ ${ }^{4}$ Departament de Geologia, Facultat de Ciències, Universidad Autònoma de Barcelona, Barcelona, Spain; \\ E-mail: enric.vicens@uab.cat
}

Numerous authors mention a notable increase in the abundance and extension of microbialites in marine environments after diverse periods of global crises of biodiversity (Schubert \& Bottjer 1992; Sheehan \& Harris 2004). In this work, we present an important accumulation of microbialites related to the $\mathrm{K} / \mathrm{T}$ boundary, inside deposits of fluvio-lacustrine origin. It is an oncolite level (level z), many of these forms being of large $(>100 \mathrm{~mm})$ size and located at the top of the so called "Sandstone of Reptiles" of the Tremp Formation, in the south-central Pyrenees (Catalonia) (López-Martínez et al. 1998). Their coincidence with a geochemical anomaly of the isotope ${ }^{13} \mathrm{C}$ that occurs near the magnetic inversion between the chrons c29r and c29n, coincidentally or immediately after the K/T boundary, the great lateral continuity in the study zone, the great size of many oncolites and, finally, their location inside one siliciclastic unit, support the hypothesis that this level of microbialites might be related to the latest Mesozoic environmental crisis. Oncolites and stromatolithic buildings also have been described by several authors in more late Paleogene levels of the Pyrenean, Ebro and Mallorca Island continental facies (Arenas et al. 2007; Zamarreño et al. 1997). Nevertheless, these microbialites probably do not present lateral continuity and commonly develop in carbonated rocks. On the other hand, it is not rejected the idea that their development was equally favoured by any Paleogene global environmental changes, such as the Eocene hyperthermals, Early Eocene Climatic Optimum, Middle Eocene Climatic Optimum and the climatic cooling of the Eocene-Oligocene transition. In this work a record of microbialites in relation with the aftermaths of the endCretaceous Mass Extinctions is reported for the first time. Likewise, this is the first time a record of this type is mentioned in continental realm. It is possible that some levels of microbialites, as disaster forms, can constitute the record of biotic crises in continental series and help to the establishment of boundaries in these series. 
Financial support by Ministerio de Educación y Ciencia of Spain (CGL2007-64061/BTE, CGL2006-04646/BTE), Eusko Jaurlaritza (GIC07/14-361) and Universidad Complutense de Madrid (GI 910161).

\section{References}

Arenas, C.; Cabrera, L. \& Ramos, E. 2007. Sedimentology of tufa facies and continental microbialites from the Paleogene of Mallorca Island (Spain). Sedimentary Geology 197: 1-27.

López-Martínez, N.; Ardèvol, L.; Arribas, M. E.; Civís, J. \& González-Delgado, A. 1998. The geological record in non-marine environments around the $\mathrm{K} / \mathrm{T}$ boundary (Tremp Formation, Spain). Bulletin de la Société Géologique de France 169 (1): 11-20.

Schubert, J. K. \& Bottjer, D. J. 1992. Early Triassic stromatolites as post-mass extinction disaster forms. Geology 20: 883-886.

Sheehan, P. M. \& Harris, M. T. 2004. Microbialite resurgence after the late Ordovician extinction. Nature 430: 75-78.

Zamarreño, I.; Anadón, P. \& Utrilla, R. 1997. Sedimentology and isotopic composition of Upper Palaeocene to Eocene non-marine stromatolites, eastern Ebro Basin, NE Spain. Sedimentology 44: 159-176.

\section{Gypsum microbialites from the Badenian of the Carpathian Foredeep [poster]}

Maciej Bąbel ${ }^{1}$, Danuta Olszewska-Nejbert ${ }^{1}$, Barbara Kremer ${ }^{2}$, Andrii Bogucki ${ }^{3}$, Andrii Yatsyshyn ${ }^{3} \&$ Maciej Śliwiński ${ }^{4}$

${ }^{1}$ Institute of Geology, University of Warsaw, Warszawa, Poland; E-mail: m.babel@uw.edu.pl \& don@uw.edu.pl

${ }^{2}$ Institute of Paleobiology, Polish Academy of Sciences, Warszawa, Poland; E-mail:

kremer@twarda.pan.pl

${ }^{3}$ Faculty of Geography, Ivan Franko National University of Lviv, Lviv, Ukraine; E-mail: jacyshyn@yahoo.com

${ }^{4}$ Department of Geology and Geophysics, University of Alaska Fairbanks, Fairbanks, Alaska, US A.; E-mail:mgsliw@comcast.net

Gypsum microbialites (GM) can be defined as organosedimentary deposits which have accreted as a result of a benthic microbial community trapping and binding detrital gypsum sediment and/or forming the locus of gypsum precipitation (Burne \& Moore 1987). Two main depositional mechanisms forming GM are thus considered and form the basis of distinguishing between two groups of GM: (i) trapping and binding (Group A) and (ii) inorganic gypsum precipitation or precipitation mediated or influenced by biological processes (Group B). In the Badenian (Middle Miocene) evaporites of the Carpathian Foredeep (best exposed in Ukraine and in Poland), GM are very common and variable (Bąbel 2005; Kasprzyk 
1993; Kwiatkowski 1970; Peryt 1996). Group B is represented by gypsum encrusted (or gypsified) microbial mats containing fenestral structures and showing wavy, crinkled laminations (sometimes only ghosts thereof) reflecting the morphology of the living mats prior to gypsification during periods of increased evaporation (Fig. 1a-c). The less common Group A is represented by crudely laminated, flat-topped domes, most commonly composed of coarse-grained gypsum.
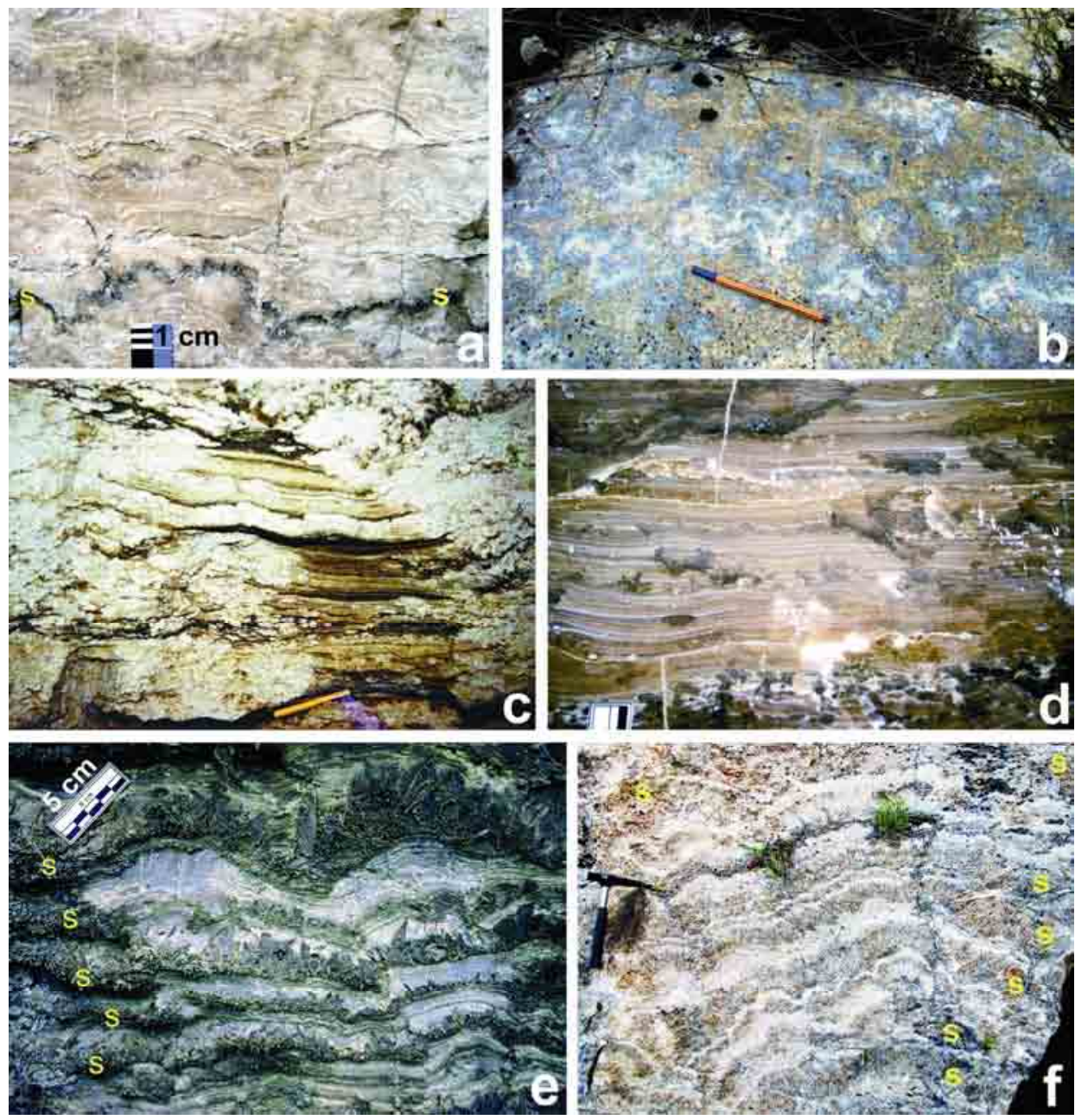

Fig. 1. Badenian gypsum microbialite (selenite marked 's'), Ukraine: (a) gypsified microbial mats, Verenchanka; (b) domal structures formed by gypsified microbial mats seen in horizontal section, Pisky; (c) channel structures within gypsified microbial mat deposits, Ozerna cave; (d) gypsum microbialite domes within clastic gypsum infilling channel structures, Mamalyha (scale as Fig. 1e); (e) gypsum microbialite domes between grass-like selenite, Pidkamin'; (f) selenite-gypsum microbialite dome, Verenchanka. 
These domes occur in channels filled with clastic laminated gypsum (Fig. 1c-d) and as intercalations within grass-like selenites (i. e. rows of large, bottom-grown gypsum crystals) (Fig. 1e). Some domes show asymmetric or elongated shapes interpreted as having been modeled by waves or currents (Kwiatkowski 1970). GM are commonly associated with selenite crystals, forming specific selenite-gypsum microbialite facies (Babel 2005), typified by large domal structures (Fig. 1f) and considered to be both microbial and chemical in origin. The gypsum microbialites of the Badenian accreted on semi-emerged shoals (Group B) and in shallow channels and on downwind shores of saline pans (Groups A and B) of a very shallow evaporite basin.

\section{References}

Bąbel, M. 2005. Selenite-gypsum microbialite facies and sedimentary evolution of the Badenian evaporite basin of the northern Carpathian Foredeep. Acta Geologica Polonica 55: 187-210.

Burne, R. V. \& Moore, L. S. 1987. Microbialites: organosedimentary deposits of benthic microbial communities. Palaios 2: 241-254.

Kasprzyk, A. 1993. Stromatolitic facies in the Badenian (middle Miocene) gypsum deposits of southern Poland. Neues Jahrbuch für Geologie und Paläontologie, Abhandlungen 187: 375-395.

Kwiatkowski, S. 1970. Origin of alabasters, intraformational breccias, folds and stromatolites in Miocene gypsum of Southern Poland. Bulletin de l'Académie Polonaise des Sciences (Série des Sciences Géologiques et Géographiques) 18 : 37-42.

Peryt, T. M. 1996. Sedimentology of Badenian (middle Miocene) gypsum in eastern Galicia, Podolia and Bukovina (West Ukraine). Sedimentology 43: 571-588.

\section{Precipitation of iron in microbial mats of the spring waters of Borra Caves, Vishakapatnam, India [talk]}

Ramanathan Baskar ${ }^{1}$, Sushmitha Baskar ${ }^{1}$, Natuschka M. Lee ${ }^{2}$, Anubha Kaushik ${ }^{1}$ \& Paongaomai K. Theophilus ${ }^{1}$

\section{${ }^{1}$ Department of Environmental Science and Engineering, Guru Jambheshwar University of Science and Technology, Haryana, India; E-mail: rbaskargjubisan@yahoo.com,aks_10@yahoo.com \& pktheophilus@gmail.com \\ ${ }^{2}$ Division Microbial Systems Ecology (MSE), Department of Microbiology, Technical University of Munich (TUM),Freising, Germany; E-mail: leen@mikro.biologie.tu-muenchen.de}

The Borra caves can be described as a speleothem cave with significant amounts of unexplored microbial mats in spring waters. The first observations and hypotheses on the possible impact of the microorganisms in these mats on the cave formation, focusing on their role on iron mineral precipitation are discussed. The spring waters $(\mathrm{pH}$ neutral 7.5-7.7) contained dissolved metals like iron and the organic mat sludge ( $\mathrm{pH} 7.0-7.3)$ had a TOC content of approximately $5.4 \mathrm{wt} \%$. Geochemically, the spring waters deep below the microbial mats contained Fe 369 ppb, 
Sr $198 \mathrm{ppb}$; and the organic mat sludge contained Mg 9 ppm, Fe $427 \mathrm{ppb}, \mathrm{Zn}$ $149 \mathrm{ppb}$, Sr $190 \mathrm{ppb}$. XRD observations displayed Fe minerals (dominantly hematite), minor amounts of zinc gallium sulfide and nitrofuryl compounds. At least four groups of bacteria identified by direct microscopy and SEM-EDX on the basis of morphology could be observed in all samples: Leptothrix-like organisms, entombed bacterial mineral sheaths, a few stalks of Gallionella-like organisms and some additional bacteria that could not be further identified. Leptotbrix-like organisms contained $43.22-60.08 \mathrm{wt} \% \mathrm{Fe}$ and the mineral precipitated near and around these bacteria (in the actual unaltered samples on site) contained 30.76$45.22 \mathrm{wt} \% \mathrm{Fe}$ as identified and quantified by SEM-EDX. This study indicated that the precipitation of these iron-rich mats in the spring waters could be linked to the presence of abundant active communities of iron precipitating bacteria at Borra caves, Vishakapatanam, India.

\section{Aerobic Methanotrophy in a Miocene seep-limestone traced by bacteriohopanepolyols and their diagenetic products [talk]}

Daniel Birgel \& Jörn Peckmann

MARUM, Universität Bremen, Bremen, Germany; E-mail:dbirgel@uni-bremen.deき peckmann@unibremen.de

Petrographical features and low $\delta^{13} \mathrm{C}_{\text {carbonate }}$ values reveal that a Miocene limestone from northern Italy (Marmorito limestone) formed at a methane seep. Although these proxies identify ancient methane-seepage, specific microbial processes, which lead to microbial precipitates can only be traced by lipid biomarkers preserved in the carbonate matrix (Peckmann \& Thiel 2004). Like at numerous other seep sites, the anaerobic oxidation of methane (AOM) was mediated by a consortium of methane-oxidizing archaea and sulphate-reducing bacteria, identified by the presence of typical biomarkers (archaeol, PMI, or terminally-branched fatty acids, respectively) (Birgel \& Peckmann 2008).

However, in this ancient seep limestone a rather unusual and unexpected biomarker signature was preserved. A suite of bacteriohopanepolyols (BHPs), socalled biohopanoids was extracted from the seep limestone. The major BHP identified is bacteriohopanetetrol (BHT), as well as abundant bacteriohopanepentol, bacteriohopaneaminotriol, and $3 \beta$-methylated BHT. Especially $3 \beta$-methylated hopanoids and bacteriohopaneaminotriol are known to be produced by cultured aerobic methanotrophic bacteria. Apart from the biohopanoids, various diagenetic hopanoids (geohopanoids) have been identified.

In particular, $3 \beta$-methylated geohopanoids such as $3 \beta-\mathrm{C}_{32}$-hopanoic acid and $3 \beta$ anhydroBHT exhibit extremely low $\delta^{13} \mathrm{C}$ values $(-100 \%)$, revealing the uptake of 
${ }^{13} \mathrm{C}$-depleted methane-derived carbon by aerobic methanotrophs. But also other, non-methylated hopanoids have been identified with similar isotopic signatures. Another group of geohopanoids was found with $\delta^{13} \mathrm{C}$ values of approximately $-40 \%$, which derive from source organisms not involved in aerobic methane oxidation. A third group is characterised by isotope values of $-75 \%$, most likely indicating mixed sources.

The presence of aerobic methane oxidation in an otherwise predominantly anoxic environment is surprising, but very steep redox gradients were only recently found in surface sediments from a modern mud volcano. There, both bacterial (aerobic) and combined archaeal and bacterial (anaerobic) methanotrophy functions in close proximity (Elvert \& Niemann 2008).

In the Marmorito limestone we found strong evidence that microaerophilic niches existed where aerobic methanotrophy was at least partially an alternative process in a principally AOM-driven system. Strong in situ brecciation of the Marmorito limestone is an important attribute, which may favour aerobic methanotrophy, resulting in an at least intermittent oxygenation. An only minor spread of $\delta^{13} \mathrm{C}$ values $(\sim 10 \%)$ of biomarkers of both anaerobic and aerobic methanotrophs agrees well with a temporal/spatial proximity of different microenvironments.

\section{References}

Birgel, D. \& Peckmann, J. 2008. Aerobic methanotrophy at ancient marine methane seeps: A synthesis. Organic Geochemistry doi:10.1016/j.orggeochem.2008.01.023.

Elvert, M. \& Niemann, H. 2008. Unusual steroid and hopanoid biosynthesis by aerobic methanotrophs at an active methane-seeping mud volcano. Organic Geochemistry 39: 167-177.

Peckmann, J. \& Thiel, V. 2004. Carbon cycling at ancient methane-seeps. Chemical Geology 205: 443467.

\section{Diversity and depositional environments of Neoproterozoic stromato- lites in the Anti-Atlas belt (Tizi n-Taghatine Group, Morocco) [poster]}

El Hafid Bouougri Department of Geology, Faculty of Sciences Semlalia, Cadi-Ayyad University, Marrakech, Morocco;
E-mail: bouougri@ucam.ac.ma

The Neoproterozoic (Cryogenian) Tizi n-Taghatine Group, Anti-Atlas Belt, contains stromatolitic assemblages within highstand system tracts deposited on a gently dipping mixed siliciclastic-carbonate ramp. Stromatolite morphologies vary with depositional environment, prevailing physical conditions and rate of terrigenous influx. Two stromatolitic assemblages are distinguished according to their occurrence within the sedimentary environment. 
Stromatolites of the first assemblage occur within a metre-scale shallowing upward siliciclastic-carbonate cycle developed on a storm-influenced mixed siliciclasticcarbonate ramp. The stromatolites range from distal inner-ramp to peritidal settings and exhibit a variety of morphotypes including domal, columnar and flatlaminated forms. Subtidal inner-ramp occurrences are dominated by domal morphotypes that overlie grainstone calcarenites and formed as $\mathrm{dm}$ - to m-thick extensive biostromes in shallow subtidal lagoon and distal inner-ramp sub-environments where high-energy settings prevailed. Proximal inner-ramp microbialites are more diversified and encompass forms including columnar, domal and planar laminated stromatolites. Domal and columnar stromatolites grew as dm-thick patchy and isolated fringing stromatolitic biostromes within the intertidal zone but may have extended to tidal channel levees. Biostromes formed in fair-weather conditions as evidenced by lack of significant elongation and scarce interbedded grainstones. Planar laminated stromatolites, characterized by typical wavy to crinkly laminations, extend to the lower supratidal zone and exhibit fenestral fabric, shrinkage cracks and breccias, together indicating periodic subaerial exposure.

Stromatolites of the second assemblage occur in metre-scale shallowing upward carbonate cycles ranging from storm influenced mid-ramp to low-energy innerramp settings. The stromatolites form the main part of the cycles and consist of $\mathrm{dm}$ - to $\mathrm{m}$-thick laterally extensive biostromes which grew in a subtidal part of the inner ramp. Most of the biostromes are composite and characterized by a significant diversity with domal, columnar, and conical columnar morphologies. They often consist of two stacked forms or rarely three morphotypes. Four types of successions are distinguished and are mainly dominated by columnar forms. In many cases, the biostromes are overlain by a cm-thick cap of columnar ministromatolites. Domal stromatolites consist of $\mathrm{dm}$-scale to m-scale domes which form contiguous buildups. Columnar stromatolites are made up of straight and often unbranching columns. Columns are spaced or contiguous and ovoid to slightly elliptical in plan view. Conical columnar stromatolites consist of coneshaped laminations which form unbranched, closely spaced to laterally linked columns. The inter-dome and inter-column spaces are usually filled with micrite and occasionally with packstone sediments of various carbonate grains, dominated by peloids and stromatoclastes derived from reworking of biostromes during episodic high energy events. With progressive shoaling, the composite biostromes grade up into planar laminated stromatolites that grew in the upper subtidal to lower intertidal zones as evidenced by the scarcity of features indicating periodic subaerial exposure.

A comparison of the two assemblages, each deposited in distinct environments, reveals that on a carbonate inner-ramp, diversity in stromatolite morphologies of subtidal biostromes is significant where low-energy conditions and low-rate terrigenous influx prevail. In contrast, on a mixed siliciclastic-carbonate inner-ramp, stromatolite diversity is more significant in the proximal part although the stress of 
intermittent siliciclastic influx restricts the wide development of microbial mats colonizing the nearshore fringe.

\section{Paleoecology and environmental significance of microbialites in carbonate platform systems: a Late Messinian example (SE Spain) [poster]}

Raphäl Bourillot ${ }^{1,2}$, Emmanuelle Vennin ${ }^{1,2} \&$ Jean-Marie Rouchy ${ }^{3,4}$

${ }^{1}$ Université de Bourgogne, Laboratoire Biogéosciences, Dijon, France; E-mail: Raphael.bourillo@ubourgogne.frevemmanuelle.vennin@u-bourgogne.fr

${ }^{2}$ CNRS, UMR 5561

${ }^{3} D$ pt.Earth History, Museum National d'Histoire Naturelle, Paris, France; E-mail: roucby@mnbn.fr ${ }^{4}$ CNRS, UMR 5143

Microbialite blooms in the Phanerozoic sedimentary reflect significant environmental modifications. Factors such as competition with metazoans, lithification parameters, substrata or microbial evolution are commonly assumed to control microbialite abundance and preservation (Garett 1970; Riding 2000).

In this work, we document an example of microbialite-rich carbonate platforms dated of the Late Messinian. The studied platforms belong to the Terminal Carbonate Complex (TCC), which developed in the western Mediterranean marginal basins immediately after the evaporites related to the Messinian Salinity Crisis (MSC). Stromatolites and thrombolites flourished on TCC platforms, developing a wide range of morphology and internal structures (Riding et al. 1991; Esteban et al. 1996; Braga et al. 1995).

Our objective is to establish the patterns of installation, acme and demise of these microbialites in the platform dynamic and to understand underlying controls. Our data come from three basins with TCC developing in different siliciclastic influx or on different substrata i. e. siliclastic, carbonated or evaporitic.

First, we used a high resolution stratigraphic approach with facies mapping on kilometric scale outcrops to establish a high resolution spatio-temporal stratigraphic framework based on geometries and surfaces. Characterization of microbialites was made using nanno- to macroscopic scale approaches: field observations and measurement, polished slabs, thin section and SEM observations coupled with mineralogical and elemental analysis. 
Our observations point out that:

(1) microbialites display significant morphological and microfabric variations along the proximal-distal platform profile. Environmental factors such as hydrodynamism or water turbidity seem to control this variability.

(2) spatio-temporal repartition of microbialites shows a first phase where microbialites are restricted in shoal or mud flat areas close to actual Bahamian examples (Dravis 1983; Dill et al. 1986). At this time, metazoan grazers such as gastropods or bivalves are diversified and abundant on the platform. In the second phase, microbialites colonize the platform, developing in a wide range of bathymetries, whereas metazoans become really scarce.

(3) This microbialitic bloom is contemporaneous of severe hydrological and climatic changes that affect the TCC platforms. Increasing humidity and dissolution of evaporites result in large fluctuations of salinity that are unfavourable to metazoan.

\section{References}

Braga, J. C.; Martin, J.M. \& Riding, R. 1995. Controls on microbial dome fabric along a carbonatesiliciclastic shelf-basin transect, Miocene, SE Spain. Palaios 10: 347-361.

Dravis, J. J. 1983. Hardened subtidal stromatolites, Bahamas. Science 219: 385-386.

Dill, R. F.; Shinn, E. A.; Jones, A. T.; Kelly, K. \& Steinen, R. P. 1986. Giant subtidal stromatolites forming in normal salinity waters. Nature 324: 55-58.

Esteban, M.; Braga, J. C.; Martin, J. \& Santisteban, C. [de] 1996. Western mediterranean reef complexes. In: Franseen, E. K.; Esteban, M.; Ward, W. C. \& Rouchy, J. M. (eds.): Models for carbonate stratigraphy from Miocene reef complexes of mediterranean regions. Concepts in sedimentology and paleontology 5: 56-72.

Garett, P. 1970. Phanerozoic stromatolites: non competitive ecologic restriction by grazing and burrowing animals. Science 169: 171-173.

Riding, R. 2000. Microbial carbonates: the geological record of calcified bacterial-algal mats and biofilms. Sedimentology 47 (suppl. 1): 179-214.

Riding, R.; Braga, J. C. \& Martin, J. M. 1991. Oolite stromatolites and thrombolites, Miocene, Spain: analogue of Recent giant Bahamian examples. Sedimentary Geology 71: 121-127.

\section{Turnover of natural exopolymeric substances: Interactions with calcium in lithifying microbial mats [talk]}

Olivier Braissant ${ }^{1}$, Alan W. Decho ${ }^{2}$, Kristen M. Przekop ${ }^{1}$, Kimberley L. Gallagher ${ }^{1}$, Christina Glunk ${ }^{3}$, Christophe Dupraz ${ }^{1} \&$ Pieter T. Visscher $^{1}$

${ }^{1}$ Center for Integrative Geosciences, University of Connecticut, Storrs, CT 06269, US A; E-mail: olivier.braissant@gmail.com,Kristen.Przekop@uconn.edu,Kimberley.gallagher@huskymail.uconn.edu \& pieter.visscher@uconn.edu 
${ }^{2}$ Department of Environmental Health Sciences, The Arnold School of Public Health, University of South Carolina, Columbia, SC, USA; E-mail: awdecho@gwm.sc.edu

${ }^{3}$ Laboratory of Geodynamic of the Biosphere, Institute of Geology, University of Neuchatel, Neuchatel, Switzerland; E-mail: christina.glunk@unine.ch

The role of bacterial exopolymeric substances (EPS) has a pivotal role in microbialite formation. In microbial mats and sedimentary biofilms, EPS provide a cohesive matrix where many biogeochemical reactions take place. With respect to carbonate mineral formation, the interactions between divalent cations (i. e., calcium and magnesium) with this matrix are of great relevance.

EPS are believed to first inhibit calcium carbonate formation by binding calcium. Such binding is mediated by chemical functional groups such as sulfate and carboxylic acids. However, once all EPS calcium binding sites are saturated with calcium, EPS have been shown to act as nucleation site and template for carbonate minerals precipitation. In microbial mats, bacterial degradation of EPS releasing calcium and increasing carbonate alkalinity seems necessary for carbonate minerals formation.

In this study, EPS from natural microbial mat have been studied using infrared spectroscopy, titrations, and x-ray photoelectron spectroscopy. Degradation of natural EPS was studied in slurry experiments. Assay of hydrolytic enzyme activities were also used as a proxy for EPS degradation. Biomineralization experiments were performed to assess the influence of fresh and degraded EPS on calcium carbonate formation.

In the microbial mat investigated, results from the slurry experiments and the enzyme assays indicate that EPS were produced and degraded mainly at the surface of the mat. In addition, titrations revealed that both fresh and degraded EPS from natural mats had a strong calcium binding capacity. However, only a fraction of the calcium in the EPS is exchanged during dialysis. Nevertheless, the calcium remaining in the EPS is sufficient to support carbonate minerals formation in biomineralization experiments. These experiments have shown that addition of fresh EPS or modified EPS in the media lead to the formation of different crystals. In conclusion, this study clearly demonstrates the role of calcium-EPS interactions in microbialite formation. 


\section{An example of dolomitic microbialites in the Holocene deposits from the Sarliève paleolake, (French Massif Central) [poster]}

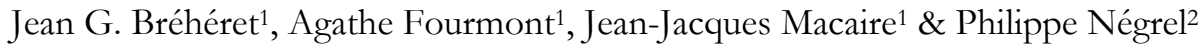

${ }^{1}$ Université François-Rabelais de Tours, UMR CNRS 6113 ISTO - Tours, Laboratoire de Géologie,

Tours, France; E-mail: breheret@univ-tours.fr, agathe.fourmont@hotmail.fr \&o jean-

jacques.macaire@univ-tours.fr

${ }^{2}$ BRGM, Orleans, France; E-mail:p.negrel@brgm.fr

For both their mineralogy and facies lacustrine bio-induced carbonates are largely controlled by hydrological factors that are highly dependant upon climatic influence. As such they are useful tools in characterizing ancient lake environments. In this way, the study of the sedimentary record from the small Sarliève paleolake (Limagne, France) is made with the aim to reconstruct the hydrological evolution during the Holocene, using petrographical, mineralogical and geochemical analyses (Bréhéret et al. 2008). The fine-grained marls, mainly calcitic, display numerous layers rich in pristine Ca-dolomite, with small amounts of aragonite, which are clearly autochthonous. As these minerals are rather unusual in the temperate climatic context of the western Europe, the question arises for their conditions of genesis, and therefore as concerns the lacustrine environment. Ca-dolomite prevails at the base of the sequence as a massive dolomicrite layer, and in the middle part, it builds up most of numerous laminae closely associated with organic matter. Scanning electron microscope observations reveal the abundance of tiny crystals (tens to hundreds $\mathrm{nm}$ ) mainly organized as microspheres looking like cocci or bacilli. Such a facies is interpreted as resulting from the fossilization of benthic microbial communities by dolomite precipitation following organic matter consumption and extracellular polymeric substances (EPS) degradation. These microbial dolomites were precipitated in a saline environment, as a consequence of an excess of evaporation from the system, as it is also suggested by their positive $\partial^{18} \mathrm{O}$ values. The facies sequence expresses the following evolution: (1) saline pan, i. e. endorheic stage with a perennial lowstand in lake level (Boreal to early Atlantic period); (2) large fluctuations in lake level with sporadic freshening of the system (Atlantic); (3) open lake stage (Subboreal); (4) anthropogenic drainage (Subatlantic).

\section{References}

Bréhéret, J. G.; Fourmont, A.; Macaire, J. J. \& Négrel, Ph. 2008. Microbially mediated carbonates in the Holocene lacustrine deposits of the Marais de Sarliève (French Massif Central) testify to the evolution of a restricted environment. Sedimentology 55: 557-578. 


\title{
Cavernous authigenic carbonate crusts at cold seeps in the eastern Mediterranean Sea-genesis and destruction [poster]
}

\author{
Florian Brinkmann, Gerhard Bohrmann \& Jörn Peckmann \\ MARUM - Center for Marine Environmental Sciences, Bremen University, Bremen, Germany; E-mail: \\ florian.brinkmann@uni-bremen.de,gbohrmann@uni-bremen.de@peckmann@uni-bremen.de
}

At the end of 2006 the expedition M70/3 with the German research vessel FS METEOR was dedicated to the analysis of cold seeps in the eastern Mediterranean Sea. In the Anaximander Mountain area, $140 \mathrm{~km}$ offshore south-west of Turkey, the Amsterdam and Athina mud volcanoes were mapped and explored using the ROV Quest. Extensive crusts of authigenic carbonate associated with methane emissions were surveyed and samples of seep carbonates were taken. Similar carbonates from that area have already been reported and have been shown to result from microbial oxidation of methane (Aloisi et al. 2000; Pancost et al. 2001). Indeed, several sites of methane discharge into the water column were found. The expelled hydrocarbon gas is oxidized via anaerobic oxidation of methane (AOM) by a consortium of sulfate-reducing bacteria and methane-oxidizing archaea. The process results in carbonate precipitation in the near-surface sediment (cf. Peckmann et al. 2001; Ritger et al. 1987). These seep carbonates mainly occurred as sprawling pavements exposed by erosion. The extensive distribution of the carbonate crusts is explained by emplacement of mud flows resulting from mud volcano eruptions.

Several samples of the crusts were obtained from a water depth between $1800 \mathrm{~m}$ and $2000 \mathrm{~m}$. The most distinctive characteristic of all samples is a macroscopic texture created by very numerous voids and cavities. Thin section analysis revealed different carbonate lithofacies. Besides the lithified hemipelagic background sediments, different later authigenic phases occur. Two predominant phases are a clotted/peloidal microcrystalline aragonite and a fibrous aragonite cement forming banded and botryoidal crystal aggregates. These two phases are always found in close spatial relationship and seem to have developed synchronously, precipitating in cavities within the background sediments. This pattern probably reflects the spatial distribution of biogeochemical hotspots. The last phase is a detrital filling that subsequently filled empty cavities and voids. The influence of AOM was confirmed by thin section analysis, the investigation of the faunal assemblage, and by both carbon isotopic investigations of carbonates $\left(\delta^{13} \mathrm{C}\right.$ values as low as $\left.-33 \% 0\right)$ and a diverse suite of ${ }^{13} \mathrm{C}$-depleted lipid biomarkers (as low as $-90 \%$ ).

The distinctive cavernous appearance is explained by different processes. Besides primary channels which were formed due to fluid and gas migration, burrowing, worm tube cementation, bioerosion contributes to cavity formation. However, the main porosity generating process is corrosion. Vast portions of all sampled crusts are affected by dissolution, possibly driven by alternating cycles of mud eruptions and erosion. Erosive periods result in aerobic condition and a $\mathrm{pCO}_{2}$ increase due 
to aerobic oxidation of methane. Additional $\mathrm{CO}_{2}$ might shift the carbonic acid / carbonate system and cause corrosive environments. Periods of mud eruptions, in contrast, would form anoxic conditions with methane-charged mud deposits. Resulting AOM would promote carbonate precipitation, and thus either formation of a new generation of authigenic carbonates.

\section{References}

Aloisi, G.; Pierre, C.; Rouchy, J.-M.; Foucher, J.-P. \& Woodside, J. 2000. Methane-related authigenic carbonates of eastern Mediterranean Sea mud volcanoes and their possible relation to gas hydrate destabilisation. Earth and Planetary Science Letters 184 (1): 321-338.

Pancost, R. D.; Hopmans, E. C. \& Sinninghe Damste, J. S. 2001. Archaeal lipids in Mediterranean cold seeps: molecular proxies for anaerobic methane oxidation. Geochimica et Cosmochimica, Acta 65 (10): 1611-1627.

Peckmann, J.; Reimer, A.; Luth, U.; Luth, C.; Hansen, B. T.; Heinicke, C.; Hoefs, J. \& Reitner, J. 2001. Methane-derived carbonates and authigenic pyrite from the northwestern Black Sea. Marine Geology 177 (1-2): 129-150.

Ritger, S.; Carson, B. \& Suess, E. 1987. Methane-derived authigenic carbonates formed by subduction-induced pore-water expulsion along the Oregon/Washington margin. Bulletin of the Geological Society of America 98: 147-156.

\section{Chemotaxonomic composition and carbon cycling in phototrophic microbial mats in a sulfur-rich spring (Zodletone, OK, USA) [talk]}

Solveig I. Bühring ${ }^{1}$, Stefan M. Sievert ${ }^{2}$, Tobias Ertefai ${ }^{1}$, Mostafa S. Elshahed ${ }^{3}$, Lee R. Krumholz ${ }^{3} \&$ Kai-Uwe Hinrichs ${ }^{1}$

${ }^{1}$ MARUM, Universität Bremen, Bremen, Germany; E-mail: solveig.buehring@uni-bremen.de, tobias.ertefai@uni-bremen.de※kbinrichs@uni-bremen.de

${ }^{2}$ Biology Department, Woods Hole Oceanographic Institution, Woods Hole, MA, US A; E-mail: ssiever@@whoi.edu

${ }^{3}$ Department of Botany and Microbiology, University of Oklahoma, Norman, OK, USA; E-mail: mostafa@okstate.edu,krumbol_@ou.edu

Zodletone spring emerges north of Zodletone Mountain in southwestern Oklahoma. This spring is characterized by a moderate temperature $\left(\sim 12^{\circ} \mathrm{C}\right)$, high concentrations of reduced sulfur compounds, short-chain gaseous alkanes, and abundant microbial mats that harbor complex prokaryotic communities. High concentrations of reduced sulfur compounds suggest sulfide as primary electron donor for anaerobic photosynthesis in this system. Microbial mats on top of the sediment in the source pool and pink streamers attached to the side walls of the source pool were analyzed for the presence of specific lipid biomarkers and incubated in the presence of ${ }^{13} \mathrm{C}$-labeled compounds to assess carbon turnover Microscopic obser- 
vations revealed filamentous cyanobacteria, motile purple sulfur bacteria, and green non-sulfur bacteria in the sediments and the pink streamers.

Further, analyses of intact polar lipids (IPLs) also revealed the presence of archaea in the source sediments, with high amounts of glyceroldialkylglycerol tetraether and archaeol. The pink streamers were characterized by high concentrations of betaine lipids (about $50 \%$ ), ornithine lipids and monogalactosyldiacylglycerol.

Additionally, labeling experiments were conducted to elucidate the importance of photoautotrophy versus photoheterotrophy and to identify the organisms responsible for the respective processes. To answer that question, ${ }^{13} \mathrm{C}$-labeled bicarbonate and acetate were added and incubated under different light conditions (light, no light, as well as exclusion of visible light or infrared (IR) light in order to match the spectral preferences of cyanobacteria and purple sulfur bacteria, respectively). Uptake of the added label into specific fatty acids was investigated and revealed pronounced differences between the treatments. High uptake into a variety of different fatty acids could be detected for the experiment with ${ }^{13} \mathrm{C}$-acetate under light compared to dark conditions, which indicates photoheterotrophy as a prominent process in this system, probably performed by purple sulfur bacteria or Chloroflexus-like anoxygenic phototrophs. Low uptake of bicarbonate under light conditions probably revealed light inhibition rather than a lack of autotrophy, because under IR-light exclusion distinct uptake into fatty acids of cyanobacterial origin was measured.

Our process-oriented investigations on modern anoxygenic microbial mats may aid in tracing and understanding microbial communities and evolution in the geological record.

\section{Hamelin Pool, Western Australia - A Modern Analogue for Kalkowsky's "Oolith und Stromatolith" Association [talk]}

Robert Burne ${ }^{1} \&$ Josef Paul ${ }^{2}$

${ }^{1}$ Research School of Earth Sciences, The Australian National University, Canberra, ACT, Australia; E-mail:robert.burne@anu.edu.au

${ }^{2}$ Geowissenschaftliches Zentrum der Universität Göttingen, Abt. Sediment/Umweltgeologie, Göttingen, Germany; E-mail:jpaul@gwdg.de

Brückmann coined the term "Oolithi" in 1721. One hundred eighty seven years later Kalkowsky described a nearby association of "oolith und stromatolith" from the Lower Triassic Buntsandstein north of the Harz Mountains in central Germany (Kalkowsky 1908). He suggested that "ooliths" and "stromatoliths" were formed by similar processes, an interpretation supported by subsequent research (Logan et 
al. 1974; Brehm et al. 2004) which concluded that both are microbialites. However, once formed, ooids behave as detrital sand grains and build ripples and sand waves (Klein 1965). It was another fifty years before Richard Chase recognized the first convincing modern analogues of "stromatoliths" around the shores of Hamelin Pool, Western Australia (R. Chase, pers. comm.). Recent investigations of both localities reveal a number of interesting parallels. In both cases stromatolites grow on stable or firm ground in turbulent environments characterized by low sedimentation rates, little fine grained sediment, virtually no terrigenous input, rapid cementation and abnormal or fluctuating salinity.

Kalkowsky's stromatolites occur on the surface of oolite beds. Laminated crusts (called stromatoid by Kalkowsky and interpreted as being formed by syndepositional cementation) also occur in these rocks. Both stromatolites and laminated crusts are concentrated in specific layers traceable throughout quarry faces. In places the stromatolites are clearly syndepositional with rippled ooid sand (Paul \& Peryt 2000: fig. 15). Spongy-fenestrate and fan-like stromatolitic microstructures can be distinguished, and both have undergone intense sparitization. The upper surfaces of some stromatolites are pitted due to syndepositional dissolution. The stromatolites may incorporate variable amounts of ooids, quartz grains and other material.

Hamelin Pool stromatolites also occur associated with ooid sands (Davies 1970; Logan et al. 1974). Subtidal stromatolites grow on rock substrate or crusts formed by penecontemporaneous cementation of marine sands, and are surrounded by mobile oolitic rippled sands and sand waves. The subtidal stromatolites have a laminoid fenestral fabric consisting of ooid and other carbonate sand grains cemented by micritic cements (Logan et al. 1974). Micritisation of sand grains begins soon after deposition and gradually destroys the original structure of the incorporated ooids and other grains (Monty 1976; Reid et al. 2003). Stromatolites in the intertidal zone are thought to be subtidal forms stranded by sea-level fall and modified by intertidal microbial communities (Burne 1991/92). While the Buntsandstein stromatolites originated in a hyposaline and alkaline lake environment during the high stand of water level, and the Hamelin Pool stromatolites a forming in a hypersaline marine embayment during a period of regression, there are many environmental similarities. In both cases conditions favourable for ooid formation precedes the initiation of stromatolite growth, but the stromatolites co-exist with ooid sands, and incorporate ooid grains into their structures. The morphology of the many of the subtidal Shark Bay stromatolites is clearly influenced by the erosive effects of ooid sand waves migrating around them. Once formed, early diagenesis progressively obliterates the structure of ooid grains incorporated into the stromatolites. The association of stromatolites and ooid sands is of considerable geological significance. In another present-day environment the stromatolites of Lee Stocking Island in the Bahamas show a similar association with migrating ooid sand waves to that found in Hamelin Pool (Dill 1991). Even the first stromatolites known to science are associated with oolitic limestones, for, 25 
years before Kalkowsky's work was published, James Hall had formally named Cryptozoon proliferum, from the oolitic Cambrian Hoyt Formation of Saratoga Springs, New York State (Hall 1883).

\section{References}

Brehm, U.; Palinska, K. A. \& Krumbein, W. E. 2004. Laboratory cultures of calcifying biomicrospheres generate ooids - A contribution to the origin of oolites. Carnets de Géologie / Notebooks on Geology, Maintenon, Letter 2004/03 (CG2004_L03): 6 pp.

Brückmann, F. E. 1721. Specimen Physicum exhibens Historiam naturalem Oolithi seu Ovariorum piscium \& concharum in saxa mutatorum. 21 pp.; Helmestadii (Salomonis Schnorrii).

Burne, R. V. 1991-92. Lilliput's Castles: Stromatolites of Hamelin Pool. Landscope 7: 34-40.

Davies, G. R. 1970. Carbonate Bank Sedimentation, Eastern Shark Bay, Western Australia. In: Logan, B. W.; Davies, G.R.; Read, J.F. \& Cebulski, D. E. (eds.): Carbonate Sedimentation and Environments, Shark Bay, Western Australia. The American Association of Petroleum Geologists, Tulsa, Oklahoma, Memoir 13: 85-168.

Dill, R. F. 1991. Subtidal Stromatolites, Ooids and Lime Encrusted Muds at the Great Bahama Bank Margin. Contributions in Marine Geology in Honour of Farncis Parker Shephard. In: Osborne, R. H. (ed.): From Shoreline to Abyss. SEPM Special Publication 46: 147-171.

Hall, J. 1883. Plate VI and explanation: Cryptozoon, N. G., Cryptozoon proliferum n. sp. In: Pierson, H. R. (ed.): Thirtysixth annual report of the trustees of the State Museum of Natural History to the legislature. N. Y. Senate paper 1883/53; Albany.

Kalkowsky, E. 1908. Oolith und Stromatolith im norddeutschen Buntsandstein. Zeitschrift der deutschen geologischen Gesellschaft 60: 68-125.

Klein, G. de Vries 1965. Dynamic Significance of Primary Structures in the Middle Jurassic Great Oolite Series, Southern England. In: Middleton, G. V. (ed.): Primary Sedimentary Structures and their Hydrodynamic Interpretation. SEPM Special Publication 12: 173-192.

Logan, B. W.; Hoffman, P. \& Gebelein, C. D. 1974. Algal Mats, Cryptalgal Fabrics, and Structures, Hamelin Pool, Western Australia. In: Logan, B. W.; Read, J. F.; Hagan, G. M.; Hoffman, P.; Brown, R. G.; Woods, P. J. \& Gebelein, C. D. (eds.): Evolution and Diagenesis of Quaternary Carbonate Sequences, Shark Bay, Western Australia. The American Association of Petroleum Geologists, Tulsa, Oklahoma, Memoir 22: 140-194.

Monty, C. L. V. 1976. The Origin and Development of Cryptalgal Fabrics. In: Walter, M. R. (ed): Stromatolites. Developments in Sedimentology 20: 193-249.

Paul, J. \& Peryt, T. M. 2000. Kalkowsky's Stromatolites Revisited (Lower Triassic Buntsandstein, Harz Mountains, Germany). Palaeogeography, Palaeoclimatology, Palaeoecology 161: 435-458.

Reid, R. P.; James, N. P.; Macintyre, I. G.; Dupraz, C. P. \& Burne, R. V. 2003. Shark Bay Stromatolites: Microfabrics and Reinterpretation of origins. Facies 49: 45-53. 


\title{
Functional complexity of living stromatolites from Shark Bay, Australia [talk]
}

\author{
Brendan P. Burns ${ }^{1,2}$, Falicia Goh ${ }^{1,3}$, Michelle Allen ${ }^{1,2}$ \& Brett A. Neilan ${ }^{1,2}$ \\ ${ }^{1}$ School of Biotechnology and Biomolecular Sciences, The University of New South Wales, Sydney, \\ Australia; E-mail:brendan.burns@unsw.edu.au,m.allen@unsw.edu.außb.neilan@unsw.edu.au \\ 2 Australian Centre for Astrobiology, Sydney, 2052, Australia \\ ${ }^{3}$ Present address: Merlion Pharmaceuticals Pty Ltd, Singapore; E-mail: silef78@yahoo.com
}

One of the major challenges in science is to identify modern living systems that present unique opportunities to address fundamental questions in diverse fields ranging from microbiology, geology, evolution, chemical biology, functional genomics, and biotechnology. The living stromatolites of Shark Bay on the western coast of Australia, represent such a system. Australia not only has some of the oldest fossilised examples of these biotic structures but also possesses some of the most extensive living examples of these aquatic ecosystems. Shark Bay is notable for its living stromatolites, and is listed as a World Heritage Site. In addition to their established evolutionary significance, these stromatolites, located in a hypersaline environment, are an ideal biological system for studying survival strategies of bacteria and halophilic archaea to high salt and their metabolic cooperation with other microorganisms. To date, little is known of the mechanisms by which stromatolite microorganisms adapt to hypersalinity. To further our understanding of these geobiological structures, detailed analyses of associated microbial communities and their functional characteristics are crucial. In this study, microbial communities were investigated using culturing and modern molecular methods. Phylogenetic analysis of the $16 \mathrm{~S}$ rRNA gene was carried out to investigate the diversity of microorganisms present. Novel organisms were isolated, and unique phylotypes from total bacterial, cyanobacterial and archaeal clone libraries were identified and putative physiologies inferred. Representative cyanobacterial isolates and Halococcus hamelinensis, a novel halophilic archaeon isolated in this study, were also examined further for osmoadaptative mechanisms. The presence of osmolytes in these microorganisms was determined by Nuclear Magnetic Resonance spectroscopy (NMR). It was found that cyanobacterial isolates were shown to utilise a range of osmolytes, including various saccharides and glycine betaine, although glucosylglycerol, unique to marine cyanobacteria was not identified. Thus cyanobacteria are likely to possess more complex mechanisms of adaptation to osmotic stress than previously thought. Findings here also indicated that stromatolite archaea accumulate glycine betaine and glutamate instead of potassium ions, and several uptake genes were identified. Signature lipid biomarkers were also assessed for both microbial mats and intertidal stromatolites from Shark Bay. Preliminary results from fatty acids, wax esters, hydrocarbons, ether-bound lipids, hopanoids and sterols indicated the presence of oxygenic phototrophs, anoxygenic phototrophs, sulfate-reducing bacteria, sulfur-oxidising bacteria, heterotrophic bacteria 
and archaea in each of the sediment types. Limited contributions from diatoms, bivalves and their dinoflagellate symbionts, and from higher plant aerosols were also detected. This data, combined with ongoing secondary ion mass spectrometry and carbon dating analyses in our laboratory, will provide clearer links between modern and ancient microbial communities. This has created a platform to increase our understanding of how microorganisms co-exist in fluctuating environments in response to solubilisation/precipitation or dilution/evaporation processes, resulting in a hypersaline environment. Through the application of a rational and integrated approach, this research has provided valuable insights into these evolutionally significant biological systems and made substantial contributions to the exciting and rapidly developing field of astrobiology.

\section{Microbial Ichnofossils derived from Microbial Mats associated to Recent Carbonates [talk]}

Elizabeth Chacón B.

Facultad de Ciencias de la Tierra, Universidad Autonoma de Nuevo Leon, Linares, México; E-mail: li:@nucleares.unam.mx

The many faces of the interaction between microbes and minerals surfaces have been constant and persistent since the early evolution of life, or even crucial for the origin of life itself. The fact that many algae and bacteria species induce the precipitation of diverse minerals as consequence of their metabolic activities is relevant in the current search for biosignatures. Since a fossil is any evidence of past microbial life preserved in the sedimentary record, endolithic fingerprints and preservable traces of their boring activity may be regarded as microbial ichnofossils, used here to indicate any mineral traces of past microbial biological activity that has been preserved in sediments and integral enough to be recognized as a biosignature. Among the most characteristic sedimentary fingerprints is the formation of destructive micritic envelopes by endolithic cyanobacteria. Less conspicuous are other sedimentary micritic coverings around bores and holes that may be regarded as microbial ichnofossils. This work presents some microbial ichnofossils characterized in recent carbonate substrates bored by endolithic cyanobacteria, putting in evidence that microbial colonization of mineral surfaces may be as ancient as life itself. A key question in astrobiology is how to distinguish between minerals precipitated spontaneously from those induced as consequence of microbial metabolisms, and if they co-occur in the same organic matrix of microbial mats? The working hypothesis proposes that minerals produced biologically may have a distinctive spatial and temporal arrangement from those produced abiogenically. This work explores microbially-induced precipitates from recent microbial mats associated with recent carbonates as good proxies for biosignatures. 


\title{
Microbial diversity of a hardwater rivulet and in deposited tufa [talk]
}

\author{
Sylvie Cousin, Evelyne Brambilla \& Erko Stackebrandt \\ DSMZ-German Collection of Microorganisms and Cell Cultures GmbH, Braunschweig, Germany; \\ E-mail:sco05@dsmz.de,ebr@dsmz.de \& erko@dsmz.de
}

In order to assess the diversity of aerobic and heterotrophic bacteria along a $400 \mathrm{~m}$ long hardwater rivulet and in vertical layers of a tufa deposit the phylogenetic position of 1.618 isolates and 2.351 partial $16 \mathrm{~S}$ rRNA clone gene sequences was assessed. While the discharge water is low in numbers and diversity, both parameters increase at three downstream sampling sites (Cousin et al. 2008). Members of Flavobacteria (Brambilla et al. 2007) and Gammaproteobacteria dominate; Betaproteobacteria and Actinobacteria were present in smaller numbers. Analysis of DNA from adjacent soil sites by Flavobacterium-specific DGGE analyses of the 16S rRNA gene V3 region suggests that the rivulet diversity is markedly influenced by bacterial diversity of the soil seeping into the rivulet (Cousin \& Stackebrandt subm.). In order to determine whether the bacterial composition of a tufa deposit differs from that of the rivulet water, a core sample was drilled from a downstream tufa site. The tufa core sample was separated into several layers of $\sim 4-6 \mathrm{~mm}$ thickness which correspond by and large to annual deposit of $\mathrm{CaCO}_{3}$. The difference in composition between water and biofilm is significant. The majority of heterotrophic isolates belong to the phylum Firmicutes while the water was almost void of these organisms. Firmicutes also dominate in other layers. Flavobacteria were present in lower numbers than in water and they are rare in deeper layers. Actinobacteria and Proteobacteria are present in all core samples, though with varying numbers in different layers.

In order to obtain a more complete overview of the bacterial diversity in the biofilm and in the core layers, assessment of phylotypes was done by molecular analysis. The community complexity of each band was first visualized by DGGE of flavobacterial rDNA. On the basis of similarities between the banding patterns clone libraries were constructed from DNA of the biofilm and seven tufa layers. After elimination of chimeric structures sequences were analysed by RDP. Phylogenetic analysis revealed membership of clone sequences to 30 phyla and "candidate" phyla, among which the most dominant ( $>$ than 100 clone sequences) were members of Alphaproteobacteria and Cyanobacteria (biofilm and core layer 1). Other phyla, like Acidobacteria, Beta, Delta, and Gammaproteobacteria, Bacteroidetes, Planctomycete Actinobacteria, Nitrospira, and, Firmicutes encompassed between 250 and 60 clones each. Yet other phyla included less than 20 clones mostly fell into "candidate" phyla. About 45 clones from layers CL1 through CL6-7 stood isolated in the tree and might correspond to putative novel "candidate" phyla.

The significant difference in the distribution of sequences of clones and isolates is not surprising as the isolation did not attempted to recover phototrophic (e. g., Cyanobacteria, chloroflexi), autotrophic, lithotrophic and anaerobic organisms. 
The fact that Firmicutes, e. g., Bacillus and Paenibacillus, are well represented among the isolates while absent in the clone libraries can be attributed to the spore stage in which these organisms may rest in the tufa core matrix.

It will be the task of subsequent studies to unravel the function of these organisms, applying metagenome analysis of the metabolically active taxa by mRNA/cDNA analysis that may help to understand the metabolic role of bacteria in the diagenesis of tufa deposits

\section{References}

Brambilla, E.; Päuker, O.; Cousin, S.; Steiner, U.; Reimer, A. \& Stackebrandt, E. (2007): High phylogenetic diversity of Flavobacterium spp. isolated from a hardwater creek, Harz Mountains, Germany. Organisms, Diversity and Evolution 7: 145-154.

Cousin, S.; Brambilla, E.; Yang, Y. \& Stackebrandt, E. (2008): Culturable aerobic bacteria from the upstream region of a karst water rivulet. International Microbiology 11: 91-100.

Cousin, S. \& Stackebrandt, E. (subm.): Spatial analysis of flavobacterial community structure in a hardwater rivulet and adjacent forest soil, Harz Mountain, Germany. Research in Microbiology.

\section{A Recently Evolved Symbiosis Between Chemoautotrophic Bacteria and a Cave-dwelling Amphipod [poster]}

Sharmishtha Dattagupta ${ }^{1} \&$ Jennifer L. Macalady ${ }^{2}$

'Courant Centre “Geobiology”, University of Göttingen, Göttingen, Germany; E-mail: sdattag@unigoettingen.de

${ }^{2}$ Department of Geosciences, The Pennsylvanian State University, State College, PA, USA; E-mail: jmacalad@geosc.psu.edu

Symbioses involving animals and chemoautotrophic bacteria form the foundation for entire ecosystems at hydrothermal vents and seeps, but have never been observed in terrestrial or freshwater environments. We discovered abundant filamenttous bacteria on the exoskeleton of Niphargus ictus, a macroinvertebrate endemic to the terrestrial, sulfidic Frasassi cave complex in central Italy. Using 16S rRNA gene sequencing and fluorescence in situ hybridization, we show that N. ictus throughout the large cave complex are colonized by a single phylotype of bacteria in the sulfuroxidizing clade Thiothrix. The epibiont phylotype differs from Thiothrix phylotypes in conspicuous biofilms in the cave streams and pools where N. ictus lives. Using a combination of ${ }^{13} \mathrm{C}$ labeling, FISH, and secondary ion mass spectrometry (SIMS) we determined that the epibiotic Thiothrix are autotrophic, establishing the first known example of a chemoautotrophic symbiosis on land. Geologic constraints imply that the Frasassi cave complex began forming by sulfuric acid dissolution between 400,000 and 1 million years ago. Therefore, the N. ictus-Tbiothrix 
symbiosis is significantly younger than marine chemoautotrophic symbioses, many of which have been evolving for tens to hundreds of million years.

\section{Study of carbonate globules in Lake Van microbialites at the nanometer-scale [talk]}

Anne-Marie Desaulty ${ }^{1}$, Nicolas Menguy ${ }^{1}$, Józef Kazmierczak ${ }^{2}$, David Moreira ${ }^{3}$, Purificación López-García ${ }^{3}$ \& Karim Benzerara ${ }^{1}$

${ }^{1}$ Institut de Minéralogie et de Physique des Milieux Condensés, Paris, France; E-mail: annemarie.desaulty@impmc.jussieu.fr, menguy@impmc.jussieu.fr_k.karim.benzerara@impmc.jussieu.fr

${ }^{2}$ Institute of Paleobiology, Polish Academy of Sciences, Warszawa, Poland; E-mail:jkaz@twarda.pam.pl

${ }^{3}$ Unité d'Ecologie, Systématique \& Evolution, CNRS UMR 8079, Université Paris-Sud, Orsay, France; E-mail:david.moreira@u-psud.fr \& purilopę@u-psud.fr

Lake Van (eastern Anatolia, Turkey) is the largest soda lake on Earth, with a $\mathrm{pH}$ of 9.7-9.8 and a salinity of $21.7 \%$ (Kempe et al. 1991). It harbors the largest known living microbialites, which are structures resulting from precipitation of aragonite at sites where calcium-rich groundwater seeps into the alkaline lake water (Kazmierczak \& Kempe 2003; Kempe et al. 1991) and are associated with a wide diversity of microorganisms (López-García et al. 2005). Lake Van microbialites have a fine-grained micritic texture similar to most carbonate microbialites (Benzerara et al. 2006). They also contain globules of few hundred of micrometers that are chemically and mineralogically zoned and have been studied previously by Kazmierczak \& Kempe (2003). They noted their similarity to the Martian ALH84001 globules and concluded that the exact mode of formation of Lake Van carbonates remains an enigma.

To get further constraints on how those structures formed, we used Scanning electron microscopy (SEM) and Transmission Electron microscopy (TEM) coupled with EDXS analyses down to the nm scale. Based on those results, we could assess the relative distributions of aragonite and a $\mathrm{Mg}, \mathrm{Fe}-$ silicate phase. Local enrichments in $\mathrm{Fe}$ and $\mathrm{Mn}$ were observed, and their speciation was determined. Finally, the texture of aragonite nanocrystals in those globules (morphology and crystallographic orientation) was studied. The results altogether question existing models of the role of microorganisms in carbonate precipitation and provide new biosignatures for these deposits. Moreover, they offer a new insight on possible differences between the processes involved in the formation of stromatolites vs. other types of microbialites. 


\section{References}

Benzerara, K.; Menguy, N.; López-García, P.; Yoon, T. H.; Kazmierczak, J.; Tyliszczak, T.; Guyot, F.; Brown, G. E. [jr.] 2006. Nanoscale detection of organic signatures in carbonate microbialites. Proceedings of the National Academy of Sciences of the USA 103: 9440-9445.

Kazmierczak, J. \& Kempe, S. 2003. Modern terrestrial analogues for the carbonate globules in Martian meteorite ALH84001. Naturwissenschaften 90 (4): 167-172.

Kempe, S.; Kazmierczak, J.; Landmann, G.; Konuk, T.; Reimer, A. \& Lipp, A. 1991. Largest known microbialites discovered in Lake Van, Turkey. Nature 349: 605-608.

López-García, P.; Kazmierczak, J.; Benzerara, K.; Kempe, S.; Guyot, F. \& Moreira, D. 2005. Bacterial diversity and carbonate precipitation in the giant microbialites from the highly alkaline Lake Van, Turkey. Extremophiles 9: 263-274.

\section{Microstromatolites implied in laminated sediments of Lake Afourgagh (Middle-Atlas, Morocco) deposits: first observations and results [poster]}

Sébastien Détriché ${ }^{1}$, Jean-Gabriel Bréhéret ${ }^{1}$, L’houcine Karrat ${ }^{2}$ \& Jean-Jacques Macaire ${ }^{1}$

${ }^{1}$ Laboratoire GéEAC, UPRES EA 2100, Faculté des Sciences et Techniques, Université Francois Rabelais, Tours, France; E-mail: sebastien.detriche@etu.univ-tours.fr \& jean-gabriel.breheret@univtours.fr

${ }^{2}$ Université Sidi Mohamed Ben Abdellah, Faculté des Sciences Dhar Mahraz. Fès, Département de Géologie, Faculté des Sciences de Fès-Atlas, Fès, Maroc; E-mail: karrat@yahoo.fr

Lake Afourgagh is a small $\left(\sim 0.03 \mathrm{~km}^{2}\right)$, shallow permanent lake ( $6 \mathrm{~m}$ deep) located in the Middle-Atlas mountain in Morocco (alt. 1380 m). Presently, Lake Afourgagh is a karstic groundwater fed, eutrophic to dystrophic restricted lake, with alkaline water. The maximum extension of the shoreline coincides with some marks of a lake stabilisation level corresponding to the lake outflow through a wadi. The lake is closed today due to successive drought but foremost to human irrigation activities since the early 1970s. The lake catchment is mainly composed of karstified Lower Lias dolomites, Middle Lias limestones, superficial Plioquaternary conglomerates and alluvial fan clays and silts. Sediments (max. thickness of $3.5 \mathrm{~m}$ ) of the lacustrine shore terrace display a 2500 year succession of alternating terms corresponding to three main macrofacies deposited on plurimetric alluvial fan silts. The first term corresponds to dark brown, compact, centimetric to decimetric paleosols in the proximal area. The second one is made of decimetric silts (sometimes organic-rich), distally transgressive on the paleosols. The third macrofacies is defined by centimetric to pluridecimetric porous, distally laminated white carbonated tufas (aragonite and low $\mathrm{Mg}$ calcite) composed of piled up encrusted stems of charophytes (Chara genus). 
In each facies, variable amounts of microstromatolitic formations of different shapes and sizes are observed. Spherulites can be concentric, polygonal (e. g. Braissant et al. 2003) or fan-shaped with clearly distinguishable growing striations. With sizes varying from micrometers to several tens of micrometers, spherulites show micritic, sparitic or radial internal structures. They can present palisades organisation or constitute cement between charophyte remnants. In tufa facies, microstromatolites are often observed on encrusted stems of charophytes, fanshaped on - but also inside - the ghosts of the cortical-cell moulds. Furthermore, microstromatolites are also developed on diatom frustules (and/or moulds), sponges spicules and organic remnants like macrophytes stems as carbonated crusts. SEM observations reveal sheaf-like structure composed of several tens of nanometers bio-induced sub-spherical crystals of aragonite and/or calcite. Even if microstromatolites structures are present in the overall deposit succession, they are mainly observed in palustrine silts and poorly preserved tufas i. e. low level lake sediments deposited in permanent to semi-permanent environment as it can be testified by the data of deposits geometry and biogenic remains such as charophytes, ostracods and diatoms (Détriché 2007; Détriché et al. 2008). Thus, this pattern may suggest a microstromatolite proliferation in environments which experience emersion phases as evoked by Verecchia et al. (1995). However, distal tufa deposits, characterized by a permanently submerged environment (with episodic low lake level) are also enriched in microstromatolites. More precisely, tufas display a laminated pattern with alternating microbial and microbial-detrital laminae suggesting seasonal lake level variations. During high lake level phases, summers could be characterized by temporary rapid emersions of the proximal and possibly the median zone of the shore terrace. In this case, proliferation of microstromatolite formations occurs, and the distally low submerged area seems to exhibit the same pattern. To conclude, it appears that microstromatolite formation in lake Afourgagh is dictated by the fluctuations of the water-table at different time scales (pluri-centennial to seasonal) and by the succession of emersion/immersion phases.

\section{References}

Braissant, O.; Cailleau, G.; Dupraz, C. \& Verecchia E. P. 2003. Bacterially induced mineralization of calcium carbonate in terrestrial environments: the role of exopolysaccharides and amino acids. Journal of Sedimentary Research 73: 485-490.

Détriché, S.; Bréhéret, J. G.; Zarki, H.; Karrat, L.; Macaire, J. J. \& Fontugne, M. 2008. Late holocene palaeohydrology of Lake Afourgagh (Middle-Atlas, Morocco) from deposit geometry and facies. Bulletin de la Société Géologique de France 79: 41-50.

Détriché, S. 2007. Evolution d'un système lacustre karstique au cours de la période historique d'après l'étude des archives sédimentaires : la dayet Afourgagh (Moyen-Atlas, Maroc). PhD thesis, Université de Tours. 372 pp.

Verecchia, E. P.; Freytet, P.; Verecchia, K. E. \& Dumont, J. L. 1995. Spherulites in calcrete laminar crusts: biogenic $\mathrm{CaCO}_{3}$ precipitation as a major contributor to crust formation. Journal of Sedimentary Research A65 (4): 690-700. 


\title{
Archaeal and bacterial diversity in saline formation water of a gas reservoir in Lower Saxony, Germany [talk]
}

\author{
Susan Ehinger, Jana Seifert and Michael Schlömann
}

AG Umweltmikrobiologie, IOEZ, TU Bergakademie Freiberg, Freiberg, Germany; E-mail: Susan.Ehinger@ioez.tu-freiberg.de,jana.seifert@ioez.tu-freiberg.de_o michael.schloemann@ioez.tufreiberg.de

Sequestration of carbon dioxide in depleted oil and gas reservoirs, deep saline aquifers or unmineable coal beds is discussed as possibility to remove the carbon dioxide from the atmosphere. Though the influence of supercritical gas to the subsurface geochemistry is a subject of several investigations, only insufficiant knowledge exists about the biological impact of the sequestrated $\mathrm{CO}_{2}$. Thus it's necessary to enhance our knowledge about microbial communities and their interactions in the subsurface of possible geological storage sites.

Gas field fluids of a deep natural gas reservoir ("Gifhorner Trog") in Lower Saxony are rich in sulphate and iron and exhibit a high salinity. Several formation water samples of those extreme microbial habitats were investigated by fluorescence insitu hybridisation (FISH) analyses. These analyses showed that various microbes could be detected under the extreme geochemical conditions in the reservoirs.

The archaeal and bacterial $16 \mathrm{~S} \mathrm{rDNA}$ of one gas field fluid was examined, to obtain more information about the composition of the microbial community in the deep subsurface. The results showed that dominant bacterial phylotypes were affiliated with the Firmicutes, the Alphaproteobacteria, the Gammaproteobacteria and the Thermotogales. A high number of $16 \mathrm{~S} \mathrm{rDNA}$ sequences were closely related to mesophilic bacteria of the genus Marinobacter.

Furthermore the archaeal $16 \mathrm{~S}$ rDNA libraries were dominated by only two different phylotypes closely related to the methylotrophic methanogen Methanolobus vulcani and the hydrogenotrophic methanogen Methanoculleus palmolei. Other $16 \mathrm{~S}$ rDNA gene sequences could be assigned to the genus Methanobacterium. Additional T-RFLP and Real-Time-PCR analyses showed that the two dominating methanogens were abundant in different well head samples of two boreholes. Merely, the proportion between them changed.

The occurrence of various groups of microorganisms in the saline, high temperature gas field fluids confirms the hypothesis that different metabolic pathways exist in the deep biosphere. The found microorganisms use electron acceptors like nitrate, sulphate or sulphur and organic compounds or hydrogen as electron donors. The availability and the supply of the microbial community with these substances is still unknown and has to be investigated. 


\section{The hidden biosphere: cryptoendolithic life in Devonian basalt [talk]}

Benjamin Eickmann ${ }^{1}$, Wolfgang Bach ${ }^{1}$, Steffen Kiel2, Joachim Reitner ${ }^{3}$ \& Jörn Peckmann ${ }^{1}$

${ }^{1}$ MARUM - Zentrum für Marine Umweltwissenschaften, Bremen, Germany; E-mail: eickmann@unibremen.de,wbach@uni-bremen.de sopeckmann@uni-bremen.de

${ }^{2}$ Institut für Geowissenschaften, Kiel, Germany; E-mail: steffen.kiel@gmx.de

${ }^{3}$ Geowissenschaftliches Zentrum Göttingen, Abt. Geobiologie, Göttingen, Germany; E-mail: jreitne@gwdg.de

The impact of biological processes on the alteration of volcanic rocks has been studied over the last decade. Recent studies on volcanic glass in massive and pillow basalts from the oceanic crust and ophiolites suggested the importance of microbes in the alteration process (Schumann et al. 2004). Alteration textures of putative biological origin include granular and tubular morphologies that form during glass dissolution by microbes and subsequent precipitation of amorphous material (Furnes et al. 2007). Here, we present observations suggesting widespread past microbial activity in vesicles of Devonian pillow basalts from Germany. Mineralized filaments within the vesicles of pillow basalts from Thuringia and Bavaria exactly mimic filaments recognized in pillow basalt from the Rheinisches Schiefergebirge, which have been interpreted to represent fossilized microorganisms (Peckmann et al. 2008). The filaments mineralized by clay minerals are found in carbonate amygdules (vesicles filled by carbonate cement) in the volcanic rock, where they started to form on the internal surface of the once water-filled vesicles. Biogenicity of the filaments is inferred from their size and shape resembling modern microorganisms including a constant diameter along the length of curved filaments. The filaments are independent of crystal faces or cleavage planes, show branching patterns reminiscent of modern microorganisms, and preferentially occur close to the margin of pillows. The most common type of filament in the Devonian basalts is up to $100 \mu \mathrm{m}$ in length and between 3 to $8 \mu \mathrm{m}$ in width. Authigenic clay minerals replacing and surrounding the filaments are similar to phases encrusting prokaryotes in modern iron-rich environments. Based on their occurrence in formerly waterfilled vesicles, the basalt-hosted filaments represent cryptoendoliths. Our new findings suggest that cryptoendolithic activity was once widespread in basalt. Future work will show if this niche of life still persists today.

\section{References}

Furnes, H.; Banerjee, N. R.; Staudigel, H.; Muehlenbachs, K.; McLoughlin, N.; Witt, M. de \& Kranendonk, M. van 2007. Comparing petrographic signatures of bioalteration in recent to Mesoarchean pillow lavas. Precambrian Research 158: 156-176.

Peckmann, J.; Bach, W.; Behrens, K. \& Reitner, J. 2008. Putative crytoendolithic life in Devonian pillow basalt, Rheinisches Schiefergebirge, Germany. Geobiology 6: 125-135.

Schumann, G.; Manz, W.; Reitner, J. \& Lustrino, M. 2004. Ancient fungal life in north Pacific Eocene oceanic crust. Geomicrobiology Journal 21: 241-246. 


\section{Microbial mats in caves as model systems for the evolution of a complex biosphere in a chemolithoautotrophic subsurface [talk]}

Annette Summers Engel ${ }^{1}$, Daniela B. Meisinger ${ }^{2}$, Megan L. Porter ${ }^{3}$, Michael Schmid ${ }^{4}$, Natuschka M. Lee ${ }^{1}$

${ }^{1}$ Louisiana State University, Department of Geology and Geophysics, Baton Rouge, Louisiana, USA; Email:aengel@geol.lsu.edu \&leen@mikro.biologie.tu-muenchen.de

${ }^{2}$ Division Microbial Systems Ecology, Department of Microbiology, Technical University of Munich, Freising, Germany; E-mail: daniela.meisinger@microbial-systems-ecology.de

${ }^{3}$ University of Maryland Baltimore County, Department of Biological Sciences, Baltimore, MD, USA; Email:porter@umbc.edu

${ }^{4}$ Helmboltz. Zentrum München, German Research Center for Environmental Health, Department Microbe-Plant-Interactions, Neuherberg, Germany; E-mail:michael.schmid@helmboltz-muenchen.de

Although the subsurface is one of the Earth's major habitats, our knowledge about the life contained within it is limited, in part because of our inability to investigate such a vast habitat. The subsurface shares several features with extra-terrestrial conditions, such as darkness, a large abundance of inorganic solutes and mineral surfaces, and extreme physicochemical conditions (e. g., temperature, $\mathrm{pH}$, organic carbon content and influx). It is currently believed that microorganisms constitute the dominant life form in the subsurface, living predominately as chemolithoautotrophs dependent on rich and diverse energy and nutrient sources. Caves and karst aquifers can serve as relatively easily accessible windows into the subsurface (Engel et al. 2004b; Krajick 2001). Here, we present our studies on the development of the microbial biosphere in dark, sulfidic caves (Lower Kane Cave, Wyoming, USA) (Engel et al. 2004a, subm.; Meisinger et al. 2007). These caves contain several sulfidic springs, where the cave stream supports a specialised community of microorganisms arranged in large microbial mats of different colours (white, black, orange). These microbial mats offer unique opportunities to study different redoxbased biogeochemical nutrient cycles, and allow us to postulate on the development of the diversity of an ecosystem in an extreme, chemoautotrophic environment. We employed a multidisciplinary approach to characterize the aerobic and anaerobic parts of the microbial mat using culture-independent and -dependent approaches to supplement our understanding of nutrient cycling and turnover functions within the whole microbial mat system. We observed that the microbial diversity was low in the upper layer of the microbial mat, consisting predominately of Epsilonproteobacteria and Gammaproteobacteria. Diversity increased signifycantly in the deeper parts of the mat, dominated by the Deltaproteobacteria and several non-culturable members of the Chloroflexi phylum and other novel candidate phyla with unknown functions. Based on our expanded insight into the diversity, abundance, and distribution of microbes within the microbial mats, we present a model for carbon and sulfur cycling that is loosely constrained by redox conditions and based on the nutrient spiraling concept. This model may support the development of astonishing microbial diversity within the microbial mats 
downstream and contribute to the emergence of a highly specialized, but low abundance, metabolic guilds in downstream reaches of the mats and in the mat interior. The geochemical, microbial, and ecological processes relevant to understanding the Lower Kane Cave system at a relatively small scale may be more significant to our general concept of redox processes and nutrient spiraling at larger habitat scales over long periods of geologic time, or in other extra-terrestrial systems.

\section{References}

Engel, A. S.; Porter, M. L.; Stern, L. A., Quinlan, S. \& Bennett, P. C. 2004a. Bacterial diversity and ecosystem function of filamentous microbial mats from aphotic (cave) sulfidic springs dominated by chemolithoautotrophic "Epsilonproteobacteria". FEMS Microbiology Ecology 51 (1): 31-53.

Engel, A. S.; Stern, L. A. \& Bennett, P. C., 2004b. Microbial contributions to cave formation: new insight into sulfuric acid speleogenesis. Geology 32 (5): 369-372.

Engel, A. S.; Meisinger, D. B.; Porter, M. L.; Schmid, M.; Stern, L. A. \& Lee, N. M. subm. Anaerobic Microbial Diversity in Redox-Stratified Microbial Mats: The Basis for Nutrient Spiraling in a Chemolithoautotrophic Ecosystem.

Krajick, K. 2001. Cave biologists unearth buried treasure. Science 293: 2378-2381.

Meisinger, D. B.; Zimmermann, J.; Ludwig, W.; Schleifer, K.-H.; Wanner, G.; Schmid, M.; Bennett, P.C.; Engel, A. S. \& Lee, N. M. 2007. In situ detection of novel Acidobacteria in microbial mats from a chemolithoautotrophically based cave ecosystem (Lower Kane Cave, WY, USA). Environmental Microbiology 9: 1523-1534.

\section{Confocal laser scanning microscopy and molecular identification of cyanobacteria in microbialites of the alkaline crater lake Alchichica (Mexico) [poster]}

Emmanuelle Gérard ${ }^{1,2}$, David Moreiraํ, Malika Ibrahimi², Karim Benzerara ${ }^{3}$, Józef Kazmierczak $^{4}$, Barbara Kremer ${ }^{4}$, Rosaluz Tavera ${ }^{6}$, Stephan Kempe ${ }^{5}$ \& Purificación López-García ${ }^{1}$

${ }^{1}$ Unité d'Ecologie, Systématique \& Evolution, CNRS UMR 8079, Université Paris-Sud, Orsay,

France; E-mail:puri.lopez@u-psud.fr \&odavid.moreira@u-psud.fr

${ }^{2}$ Institut de Physique du Globe de Paris, Paris, France; E-mail: emgerard@jpgp.jussieu.fr

${ }^{3}$ Institut de Minéralogie et de Physique des Milieux Condensés, Paris, France; E-mail:

karim.benzerara@impmc.jussieu.fr

${ }^{4}$ Institute of Paleobiology, Polish Academy of Sciences, Warszawa, Poland; E-mail:jkaz@twarda.pan.pl \&kremen@twarda.pan.pl

${ }^{5}$ Institute for Applied Geosciences, TU Darmstadt, Darmstadt, Germany; E-mail: kempe@geo.tudarmstadt.de

${ }^{6}$ Ecology and Natural Resources Department, School of Sciences, UNAM, México City, México; E-mail:rts@hp.fciencias.unam.mx 
Alchichica is an alkaline $(\mathrm{pH} \sim 8.9)$ crater lake located at high altitude $(2,300 \mathrm{~m}$ above sea level) in the Puebla State, Mexico, that harbours an extensive collection of living microbialites. We sampled Alchichica microbialites in June 2007 at differrent depths in the lake from the shore to $14 \mathrm{~m}$ depth and fixed them in situ. A few samples were kept alive in laboratory aquaria for continuous survey. A preliminary study of the microbial diversity associated to microbialites of different depth, with a particular focus on the cyanobacterial component, has been carried out using both, molecular methods and laser confocal microscopy imaging. We amplified, cloned and sequenced 16S rRNA genes of three different depths using primers specific for bacteria and for cyanobacteria. Our results showed a large diversity of cyanobacterial lineages covering a wide spectrum of cyanobacterial taxa both including filamentous (Oscillatoriales, Rivularia and Calotbrix-like Nostocales) and non-filamentous species (Pleurocapsales, Chroococcales and the recently described Acaryochloris group). Various phylotypes were very distantly related to all known cyanobacterial species. In addition, we examined microbialite samples from differrent depths and from laboratory aquaria under confocal laser scanning microscopy (CLSM), a technique coupling optical microscopy to the detection of fluorescence emission by the target object after excitation by a laser beam. The reconstruction of three-dimensional images from relatively thick objects is made possible by optical sectioning. By illuminating the samples with six different laser beams from the ultraviolet to the infrared, we were able to distinguish different cyanobacterial cells in situ as a function of their morphology but also their fluorescence emission and, hence, pigment content. Coccoid cyanobacteria were more abundant in deep microbialites. This approach is promising to map cyanobacterial cells sharing the same morphology but with distinct pigment content in complex communities.

\section{The ancient and modern microbial communities and their laboratory models [poster]}

Ludmila M. Gerasimenko ${ }^{1}$, Elena A. Zhegallo², Vladimir K. Orleansky ${ }^{1} \&$ Galina T. Ushatinskaya ${ }^{2}$

${ }^{1}$ Winogradsky Institute of Microbiology RAS, Moscow, Russia; E-mail: L_Gerasimenko@mail.ru \& orleanor@mail.ru

${ }^{2}$ Paleontological Institute RAS, Moscow, Russia; E-mail: ezheg@paleo.ru\&gushat@paleo.ru

The algae-bacterial and cyanobacterial communities (mats) of hypersaline lakes and lagoons attract much attention because their study helps to understand the processes leading to mass development of ancient stromatolites on the Earth. Saline lakes in Kerch peninsula (Koyashskoe, Marfovskoe and Tobechikskoe) were studied. Different cyano- and algae-bacterial biofilms and -mats with laminated 
structure, containing Cladophora sp., cyanobacteria and purple bacteria as the main phototrophic organisms were found in these lakes.

There are good outcrops of Miocene and Paleocene deposits in Kerch peninsula near studying saline lakes. These outcrops contain of stromatolites and oncolites. Stromatolites in the lower part of the sand-carbonate strata of Karagan horizon (middle Miocene) develop near v. Marfovka and near the coast cliff of the lake Tobechiksckoe. They consist of the alteration of lighter and darker layers. The presence of $\mathrm{Mn}$ and Fe, typically Mn-mineral structures like the growing bush and manganiferous remains of the worms, foraminifers were discovered in the dark layers with LINK and SEM. The oncolites samples consisting of the alteration of lighter and darker layers from Koyashskoe lake shore (Pliocene Kimmery or Akchagyl age) are interesting as well.

The comparing of morphological peculiarities of algae and cyanobacteria remnants found among fossil stromatolites with algae-bacterial associations from recent saline lakes Kerch peninsula shows that they are almost identical.

How were Mn-stromatolites formed? For answer on this question the laboratory experiment was made with halophilic cyanobacteria. They were grown in the cultural medium under different $\mathrm{Mn}$ concentration $\left(0.05-5 \mathrm{~g} / 1 \mathrm{MnCl}_{2}\right)$ and contained $\mathrm{NaHCO}_{3}$. Under concentration $0.05-0,1 \mathrm{~g} / \mathrm{l}$ cyanobacteria continued to grow up without morphological changes. The accumulation of $\mathrm{Mn}$ took place only on the dead trichomes and glycocalyx on the bottom of glass. Inhibition of the growth of cyanobacteria was begun under concentration $\mathrm{Mn}=0.5 \mathrm{~g} / \mathrm{l}$. Some trichomes of cyanobacteria were destroyed and $1-2 \mathrm{mkm}$ globules of $\mathrm{MnCO}_{3}$ (mineral rhodochrosite?) were precipitated. Large peak of $\mathrm{Mn}$ in the living trichomes of cyanobacteria was found. This Mn concentration was took for forming the laboratory model of "Mn stromatolite". Its laminated srtucture was obtained with alternational addition of $\mathrm{MnCl}_{2}$ and $\mathrm{CaCl}_{2}$ in cultural medium. The mineral layers $\mathrm{CaCO}_{3}$ (white layer) were alternated with organic layer with $\mathrm{Mn}$ (black layers).

It is possible to suppose that the formation of Karagan stromatolites and Pliocene onkolites occurred in the sea lagoons, on the shallow waters.

The research has been carried out with financial support from Presidium of RAS (Program "Biosphere Origin and Evolution"). 


\title{
Giant Holocene freshwater "stromatolites", Laguna Bacalar, Quin- tana Roo, Mexico [talk]
}

\author{
Eberhard Gischler ${ }^{1}$, Michael A. Gibson ${ }^{2} \&$ Wolfgang Oschmann ${ }^{1}$ \\ ${ }^{1}$ Institut für Geowissenschaften, Goethe-Universität, Frankfurt am Main, Germany; E-mail: \\ gischler@em.uni-frank.furt.de \&oschmann@em.uni-frankfurt.de \\ ${ }^{2}$ University of Tennessee, Department of Geology, Geography \& Physics, Martin, TN, US A; E-mail: \\ mgibson@utm.edu
}

With more than $10 \mathrm{~km}$ of total length, Holocene "stromatolites" in Laguna Bacalar, Mexico, belong to the largest freshwater microbialite occurrences. Microbialites include domes, ledges and oncolites. Domal forms can grow to diameters and heights of $3 \mathrm{~m}$. Microbialites are composed of low-magnesium-calcite, which is to a large part precipitated due to the metabolic activity of the cyanobacteria Homeothrix and Leptolyngbya, and associated diatoms. Photosynthesis removes carbon dioxide and triggers carbonate precipitation. Also, elevated carbonate concentration in lagoon waters, derived from dissolution of Cenozoic limestone in a karst system, supports carbonate precipitation. Trapping and binding of detrital grains is also observed, but is not as common as precipitation. Bacalar microbialites are largely thrombolitic, however, stromatolitic sections occur as well. The bulk of Bacalar microbialites probably formed in the late Holocene (ca. $1 \mathrm{kyr}$ BP until present). According to ${ }^{14} \mathrm{C}$ dating, microbialites accreted 9 to $8 \mathrm{kyrs} \mathrm{BP}$, however, these ages may be too old as a result of a strong hard water effect. This effect is seen in ${ }^{14} \mathrm{C}$ ages of living bivalve and gastropod mollusc shells from Bacalar Lagoon, which comes out 8 to $7 \mathrm{kyrs}$ BP. The modern associated fauna of microbialites is characterized by low diversity and high abundance of the bivalve mollusk Dreissena sp. and the gastropod Pomacea sp. The abundant grazing gastropods presumably hamper modern microbialite formation. A comparison of Bacalar microbialites with other modern microbialite occurrences worldwide shows only few patterns: sizes, shapes, microbial taxa, mineralogy, type of accretion and settings including water properties of microbialite occurrences exhibit high variability. A trend may be seen in the grazing metazoa, which are rare to absent in the marine and brackish examples but apparently present in all the freshwater occurrences of microbialites. Also, freshwater examples are usually characterized by elevated concentrations of carbonate and/or calcium ions in the surrounding waters.

\section{Reference}

Gischler, E.; Gibson, M. A. \& Oschmann, W. 2008. Giant Holocene freshwater microbialites, Laguna Bacalar, Quintana Roo, Mexico. Sedimentology 55. doi: 10.1111/j.1365-3091.2007.00946.x 


\title{
Stromatolites and microbial mats as engineers of first metazoan ecosystems [talk]
}

\author{
Dmitriy Grazhdankin
}

Institute of Petroleum Geology and Geophysics, Novosibirsk, Russia; E-mail:f6oeoua@mac.com

The biosphere's earliest known macrobenthic communities are represented by the extinct late Proterozoic Avalon-, Ediacaran- and Nama-type biotas. These assemblages were specially adapted to coexist with ubiquitous microbial substrates in low-energy shelf (Avalon-type biotas), wave- and current-agitated shoreface (Ediacara-type biotas) and fluviomarine deposits (Nama-type biotas). Colonization of microbial substrates started in low-energy shelf environments $580 \mathrm{Ma}$ ago and was followed by expansion into outer prodelta fans and sandy channelized shoals $560 \mathrm{Ma}$ ago; however, organisms never used microbial substrates for permanent attachment. Cyanobacterial mats require access to light, therefore when shaded their primary production ceases, and the biofilms slowly lose their integrity due to degradation of the cyanobacterial mucous excretion. Furthermore, a thin leatherlike elastic cover would certainly offer a rather unstable substrate for settling, and sessile, immobile macroscopic organisms could become easily uprooted by waves and currents. Finally, organisms living on microbial mats would have to contend with strong fluctuations in oxygen tension - from supersaturation during the day and anoxia and sulfidic conditions during the night. This applies to modern mats, and also applied in the Proterozoic. Organisms inhabiting microbial substrates were therefore left with three options: to become imbedded into the microbial mats, to become rooted to the substrate underneath the microbial mats, or to become active, motile creatures. All these strategies were successfully utilized in earliest macrobenthic communities. Bioturbation first appeared in low-energy settings ca. $550 \mathrm{Ma}$ ago, where it coexisted with microbial substrates, columnar stromatolites and Avalon-type macroorganisms. The increase in behavioral complexity of borrowing organisms was accompanied by their rapid expansion into non-marine, delta plane environments, whereas microbial substrates persisted unaltered in wave- and current agitated shoreface settings through the ProterozoicPhanerozoic transition. Stromatolite buildups remained the dominant facies of late Proterozoic carbonate shelves and hosted the earliest communities of metazoans with biologically controlled mineralization. Thus, neither the emergence of disparate macrobenthic communities nor the appearance of bioturbation could be recognized as a cause of major stromatolite decline at the end of Proterozoic. 


\section{A comparative study of microbialites from modern Hydrate Ridge and ancient Lincoln Creek Formation methane-seeps using high- resolution biosignature analyses [poster]}

Andrea Hagemann ${ }^{1}$, Tim Leefmann ${ }^{1}$, Veit-Enno Hoffmann², Andreas Pack ${ }^{3}$, Jörn Peckmann $^{5}$, Jan Bauermeister ${ }^{1}$, Volker Liebetrau ${ }^{6}$, Andreas Kronz ${ }^{4}$, Joachim Reitner ${ }^{1} \&$ Volker Thiel $^{1}$

${ }^{1}$ Geowissenschaftliches Zentrum der Universität Göttingen, Abt. Geobiologie, Göttingen, Germany;

E-mail: ahagema@gwdg.de,tleefma@gwdg.de,jbauerm@gwdg.de,jreitne@gwdg.de d vthiel@gwdg.de

${ }^{2}$ Geowissenschaftliches Zentrum der Universität Göttingen, Abt. Sedimentologie/Umweltgeologie, Göttingen, Germany; E-mail: vhoffma@gwdg.de

${ }^{3}$ Geowissenschaftliches Zentrum der Universität Göttingen, Abt. Isotopengeologie, Göttingen, Germany; E-mail:apack@uni-goettingen.de

${ }^{4}$ Geowissenschaftliches Zentrum der Universität Göttingen, Abt. Geochemie, Göttingen, Germany; E-mail:akronz@gwdg.de

${ }^{5}$ University of Bremen, MARUM, Bremen, Germany; E-mail:peckmann@uni-bremen.de

${ }^{6}$ Leibniz-Institut für Meereswissenschaften (IfM-GEOMAR), Kiel, Germany; E-mail:vliebetran@ifmgeomar.de

Methane related microbialites characteristically feature several closely associated mineral phases, which relations to different biogeochemical processes or microorganisms are difficult to evaluate.

In this study we characterized individual phases of microbialites from Hydrate Ridge (off Oregon, U.S.A.) and from the Oligocene part of the Lincoln Creek Formation (Canyon River deposit, western Washington State, U.S.A.) by combining phase specific probing for lipid biomarkers and carbon isotopes with the analysis of petrographic traits. This revealed indications for organisms and mechanisms involved in the precipitation of the carbonates.

The Hydrate Ridge carbonates predominantly consist of gray micrite, whitish aragonite, and lucent aragonite. The carbonates from the Canyon River also show several petrographically and isotopically distinguishable phases, namely micrite, yellow aragonite, clear botryoidal aragonite, and equant calcite spar.

Within the Hydrate Ridge carbonates, lipid biomarkers of microorganisms involved in the anaerobic oxidation of methane (AOM) were found to be highly enriched in the whitish aragonite. These biomarkers encompassed tail-to-tail linked irregular isoprenoid hydrocarbons, 1,2-dialkylglycerolethers (DAGE), archaeol, and hydroxyarchaeol. The lucent aragonite contains only small amounts of specific biomarkers, whereas the gray micrite shows small to moderate amounts.

The Canyon River carbonates contain similar AOM related biomarkers that show an analogous phase specificity. Combining biomarker and petrographic traits, we 
propose a similar formation mechanism of the precipitates from both methaneseep environments under periodically occurring pulses of methane-rich fluids. The Lincoln Creek Formation deposits can consequently be regarded as ancient counterparts of the carbonates forming in the modern Hydrate Ridge setting.

\title{
Isolation of novel iron-oxidizing bacteria from an recently characterized community in an acid mine water treatment plant [talk]
}

\author{
Sabrina Hedrich, Elke Heinzel, Jana Seifert \& Michael Schlömann \\ Institut für Biowissenschaften, AG Umweltmikrobiologie, TU Bergakademie Freiberg, Freiberg, \\ Gerrmany; E-mail: sabrina.hedrich@ioez:tu-freiberg.de,elke.heinzel@ioez:tu-freiberg.de, \\ jana.seifert@ioez.tu-freiberg.de \&o michael.schloemann@ioez.tu-freiberg.de
}

In the Lusatia area (Germany) a pilot plant for the treatment of iron and sulphate rich acidic mine waters by microbial iron oxidation and a concomitant iron hydroxysulfate precipitation is operated. The identification of the bacteria involved in the iron oxidizing process and the knowledge of their physiological characteristics will help to vary parameters in the pilot plant to optimize the process and improve waste water remediation.

Molecular based studies of the acidic water and mineral samples from the iron hydroxysulfate precipitate revealed the presence of $16 \mathrm{~S}$ rRNA gene sequences from various undescribed iron-oxidizing bacteria (IOB) (Heinzel et al. 2008).

For a physiological characterisation of the IOB different cultivation techniques were used. Once water samples from the pilot plant were directly plated on various solid media. Due to the high sensitivity of autotrophic bacteria to organic substances overlay plates with a heterotrophic Acidiphilium-strain in the underlayer were used (Johnson \& Hallberg 2007). The used media differ in the addition of organic carbon sources and the $\mathrm{pH}$ value. Ferric iron encrusted colonies could be observed after three weeks of incubation. The phylogeny of these isolates was determined by sequencing. Many of the isolates are related to Acidithiobacillus ferrooxidans strains. Furthermore a species which affiliates to the genus Thiomonas and interestingly one that is related to the so far undescribed Betaproteobacterium Ferrovum myxofaciens were isolated. Ferrovum myxofaciens is related to Gallionella ferruginea, which is commonly isolated from neutral waters. To enrich the Gallionella related bacteria gradient tubes containing different ferrous iron sources were prepared (Hallbeck et al. 1993). The culture conditions were modified by setting up various $\mathrm{pH}$ values. A community of three so far uncultured iron oxidizing bacteria could be enriched, where the dominating species is a Gallionella related bacterium recently detected in acidic spa waters (Hallberg et al. 2006). 
Acknowledgements: This work was sponsored by the scholarship programme of the German Federal Environmental Foundation. We are grateful to G.E.O.S. Freiberg for providing the pilot plant samples and chemical data. We thank D.B. Johnson and the BART team for their help and the opportunity to visit their lab and the DAAD for sponsoring this scientific exchange.

\section{References}

Hallbeck, L.; Ståhl, F. \& Pedersen, K. 1993. Phylogeny and phenotypic characterization of the stalkforming and iron-oxidizing bacterium Gallionella ferruginea. Journal of General Microbiology 139 (7): 1531-1535.

Hallberg, K. B.; Coupland, K.; Kimura, S. \& Johnson, D. B. 2006. Macroscopic Streamer Growths in Acidic, Metal-rich Mine Waters in North Wales Consists of Novel and Remarkably Simple Bacterial Communities. Applied and Environmental Microbiology 72: 2022-2030.

Heinzel, E.; Hedrich, S.; Janneck, E.; Glombitza, F., Seifert, J. \& Schlömann, M. 2008. Diversity of bacteria in a pilot plant for the treatment of mine water by biological ferrous iron oxidation. Applied and Environmental Microbiology. submitted.

Johnson, D. B. \& Hallberg, K. B. 2007. Techniques for detection and identifying acidophilic mineraloxidising microorganisms. In: Rawlings, D. E. \& Johnson, D. B. (eds.): Biomining. pp. 237-262; Berlin \& Heidelberg (Springer).

\section{Molecular mappings of recent and fossil mineralised microbial samples using Time of flight - Secondary ion Mass Spectro- metry [talk]}

Christine Heim¹, Jukka Lausmaa ${ }^{2}$, Peter Sjövall ${ }^{2}$, Gernot Arp¹, Uwe Hahmann ${ }^{3}$ \& Volker Thiel ${ }^{1}$

${ }^{1}$ Geoscience Center, University of Göttingen, Department of Geobiology, Göttingen, Germany; E-mail: cheim@gwdg.de,garp@gwdg.de \& vthiel@gwdg.de

${ }^{2}$ SP Swedish National Testing and Research Institute, Department of Chemistry and Materials Technology, Boras, Sweden; E-mail:juk.ka.lausmaa@sp.se \& peter.sjovall@sp.se

${ }^{3}$ Institute of Neuropathology, University Hospital of Göttingen, Prion Research Unit, Göttingen, Germany; E-mail:uhabmann@med.uni-goettingen.de

The simultaneous identification and mapping of organic biomarkers and related mineral phases 'on the sample' has been a long-standing challenge in organic geochemistry. Time of Flight - Secondary Ion Mass Spectrometry (ToF-SIMS) with cluster primary ion sources provides an innovative tool for simultaneously detecting inorganic and organic molecules with a very high (sub- $\mu \mathrm{m}$; Hagenhoff 2000) lateral resolution and displaying their intensities in a given area of interest. Compound identification can be achieved through the precise mass determination of the molecular species and through the analysis of characteristic molecular fragments, as in conventional extraction-based techniques (GC/MS and LC/MS). 
In this talk, we give an introduction of ToF-SIMS imaging mass spectrometry to a non-specialist audience and exemplify its potential for geobiological applications by studies on microbial mats and biominerals. Utilizing the imaging capability of ToFSIMS, the spatial distributions of various biomarkers were mapped at a lateral resolution of $<5 \mu \mathrm{m}$ in $500 \times 500 \mu \mathrm{m}^{2}$ areas on microscopic cryosections and rock sections, respectively. In a carbonate precipitating microbial mat from methane seeps in the Black Sea (Michaelis et al. 2002), the distributions of intact archaeal isopranyl diether and tetraether lipids were recorded by ToF-SIMS and correlated with the presence of distinctive microbial consortia and carbonate precipitates using 'post-measurement' fluorescence microscopy on the same samples (Thiel et al. 2007). Aiming to identify a fossil deep biosphere in the $1.8 \mathrm{Ga}$ old Äspö diorite (Pedersen 1997), ToF-SIMS was also performed on fracture fillings consisting of a sequence of high-temperature fluorite and low-temperature calcite phases. ToFSIMS spectra of these samples reproducibly revealed numerous organic compounds with masses as high as $325 \mathrm{Da}$ within the fracture fillings. Molecular mappings indicated an indigenous origin most likely from subterranean biofilms, as these compounds showed a very specific distribution, exactly following the boundary between calcite and fluorite phases at a thickness of about 200-300 $\mu \mathrm{m}$. ToFSIMS molecular imaging, in conjunction with other techniques, thus offers an interesting perspective for a wide range of geobiological applications, which require detecting and localizing organic and inorganic compounds at a high lateral resolution.

\section{References}

Hagenhoff, B. 2000. High resolution surface analysis by TOF-SIMS. Microchimica Acta 132: 259-271.

Michaelis, W.; Seifert, R.; Nauhaus, K.; Treude, T.; Thiel, V.; Blumenberg, M.; Knittel, K.; Gieseke, A.; Peterknecht, K.; Pape, T.; Boetius, A.; Amann, R.; Jørgensen, B. B.; Widdel, F.; Peckmann, J.; Pimenov, N. V. \& Gulin, M. B. 2002. Microbial reefs in the Black Sea fueled by anaerobic oxidation of methane. Science 297: 1013-1015.

Pedersen, K. 1997. Microbial life in deep granitic rock. FEMS Microbiology Reviews 20: 399-414.

Thiel, V.; Heim, C.; Arp, G.; Hahmann, U.; Sjövall, P. \& Lausmaa, J. 2007. Biomarkers at the microscopic range: ToF-SIMS molecular imaging of Archaea-derived lipids in a microbial mat. Geobiology 5: 413-421.

\section{Origin of laminated microbialites in coral reefs from the last deglaciation off Tahiti (IODP 310) [talk]}

Katrin Heindel, Daniel Birgel, Hildegard Westphal \& Jörn Peckmann

Geosciences Department, University of Bremen, MARUM, Bremen, Germany; E-mail: kheindel@unibremen.de,dbirgel@uni-bremen.de, bildegard.westphal@uni-bremen.de or peckmann@rcom-bremen.de 
During IODP Expedition 310, drowned Pleistocene to Holocene barrier reefs seaward of the modern fringing reefs of the far-field site Tahiti has been drilled. The purpose of IODP 310 was to reconstruct the post-glacial sea-level rise, based on the assumption that Tahitian coral reefs precisely record the rapid sea-level rise of the last deglacial.

The Tahitian deglacial reef-succession is a coral framework encrusted by coralline algae and subsequently by laminated microbialites, locally succeeded by dendritic microbialites. The predominance of microbialites (up to $80 \mathrm{vol} . \%$ ) is rather uncommon for shallow-water coral reefs. Although microbialites represent a potential archive for a wide range of environmental parameters, conditions favouring their genesis are still poorly understood.

Therefore, this study focuses on a) the identification of the microbial communities involved in carbonate formation, and b) the interpretation of geochemical signatures tracking environmental changes from the Last Glacial Maximum to present interglacial.

Dispersed framboidal pyrite resulted most likely from the activity of sulphatereducing bacteria. Abundant terminally-branched fatty acids (iso-/anteiso $\mathrm{C}_{15}$ and $\mathrm{C}_{17}$ ) exhibit that sulphate-reducing bacteria (SRB) most likely induced carbonate precipitation. Compound-specific $\delta^{13} \mathrm{C}$-values of SRB-derived fatty acids are unusually high ( -20 to $-17 \%$ ), similar to the isotopic composition of total organic matter, which shows only slightly higher values (mean: $-19.6 \%$ ). This may be interpreted as the signature of heterotrophic sulphate-reduction. Lipid biomarkers of cyanobacteria forming many modern microbialites were not identified.

The dark lamination of the Tahitian microbialites is characterised by a higher proportion of volcanoclastic minerals compared to the light laminae (thin sections, Laserablation ICP-MS). Furthermore, high-resolution micro-isotopic measurements $\left(\delta^{18} \mathrm{O}\right.$ and $\left.\delta^{13} \mathrm{C}\right)$ perpendicular to the lamination indicate periodically (seasonal?) increased humidity.

We interpret that, periodically increased rain-fall probably has lead to periods of elevated sediment influx and therefore to a higher nutrient-level which influences the coral ecosystem at the same time. Microbial growth and activity is supposed to be linked to those cycles. The laminated microbial crusts, thus, reflect changing sediment input and trophic conditions during the last deglacial sea-level rise. 


\title{
Microbioerosion in microbialites and corals from Tahitian post-LGM reefs (IODP 310) [poster]
}

\author{
Katrin Heindel ${ }^{1}$, Max Wisshak ${ }^{2} \&$ Hildegard Westphal $^{1}$ \\ ${ }^{1}$ Geosciences Department, University of Bremen, MARUM, Bremen, Germany; E-mail: kheindel@uni- \\ bremen.de \& bildegard.westphal@uni-bremen.de \\ ${ }^{2}$ GeoZentrum Nordbayern, Erlangen University, Erlangen, Germany; E-mail: wisshak@pal.uni- \\ erlangen.de
}

During IODP Expedition 310, drowned Pleistocene to Holocene barrier reefs seaward of the modern fringing reefs off Tahiti has been drilled. The purpose of IODP 310, the reconstruction of post-glacial sea-level rise, was based on the assumption that the coral reefs of Tahiti precisely record the rapid last deglacial sea-level rise.

The Tahitian deglacial reef-succession typically consists of coral framework encrusted by coralline algae and subsequently by thick crusts of microbialites. The high abundance of microbialites (up to 80 vol. \%) is uncommon for shallow-water coral reefs. These microbialites represent a potential archive for a wide range of environmental parameters, but their genesis is not sufficiently understood so far.

Microbioerosion patterns in the three principal framework components (corals, coralline algae, and microbialites) were studied in order to unravel environmental information recorded in the ichnocoenosis. Index-communities of microbioerosional traces yield a record of relative light availability during coral growth and following red algal and microbial encrustation. This allows to constrain palaeobathymetry and the relative timing within the context of the deglacial coral reef development.

Most of the bioerosion traces that were produced by cyanobacteria and chlorophytes are typical representatives of the deep-euphotic (down to $1 \%$ surface illumination) to dysphotic zone ( 0.001 to $0.1 \%$ surface illumination). Unexpectedly for a tropical light-flooded setting, the key ichnotaxa for the shallow euphotic zone are scarce in the analysed sample-set, and are restricted to the base of the deglacial succession. Thus reflects the deglacial sea-level rise: glacial sea-level lowstand at the base of succession (euphotic conditions), rising deglacial sea-level towards the top of succession (dysphotic conditions).

At the base of the deglacial reef-succession, the ichnocoenoses present in the corals indicate shallower bathymetries than those in the encrusting microbialites. This is in agreement with the rapid deglacial sea-level rise and with radiocarbon data which confirm a time gap of more than 600 years between coral death and microbialite formation at the base of the succession. Furthermore, uniform palaeobathymetries in the three principal framework components from the top of the deglacial reef succession and radiocarbon ages imply that encrustation of the corals by coralline algae and microbialites took place shortly after coral demise. 
An enigma arises from the fact that the identified ichnocoenoses imply prevailing deeper euphotic to dysphotic conditions that appear too deep for zooxanthellate coral-growth. During the deglacial sea-level rise (seasonally?) enhanced nutrients and volcanoclastic influx by rivers may have led to eutrophication. This would have condensed the photic zonation thereby exerting considerable stress on the coral ecosystem, and additionally have played a significant role in microbial blooms initiating microbialite development.

\section{Methane-derived microbialites: biomarker evidence of microbes per- forming anaerobic oxidation of methane in the Carboniferous [talk]}

Tobias Himmler ${ }^{1}$, Daniel Birgel ${ }^{1}$, André Freiwald ${ }^{2} \&$ Jörn Peckmann ${ }^{1}$

${ }^{1}$ MARUM - Zentrum für Marine Umweltwissenschaften, Universität Bremen, Bremen, Germany;

E-mail:tbimmlen@uni-bremen.de,dbirge@@uni-bremen.desspeckmann@uni-bremen.de

${ }^{2}$ Geozentrum Nordbayern, FG Paläoumwelt, Universität Erlangen, Erlangen, Germany; E-mail: freiwald@pal.uni-erlangen.de

Late Carboniferous limestones from southern Namibia formed as a result of microbial activity at a methane seep. The process that induced carbonate precipitation was anaerobic oxidation of methane, mediated by methanotrophic archaea and sulphate-reducing bacteria. This is revealed by lipid biomarkers extracted from the limestone (Birgel et al. 2008). The limestone contains sourcespecific ${ }^{13} \mathrm{C}$-depleted biomarkers of fossil methanotrophic archaea and sulphatereducing bacteria, including pentamethylicosane (PMI) (-113\%o V-PDB) and a mixture of crocetane/phytane (-112\% V-PDB), as well as iso- and anteiso-alkanes ( $-88 \%$ V-PDB), respectively. As these biomarkers are enclosed in the product of microbial metabolism, the syngenicity of the microbial limestone and the enclosed molecular fossils (i. e., lipid biomarkers) is unambiguous.

\section{References}

Birgel, D.; Himmler, T.; Freiwald, A. \& Peckmann, J. 2008. A new constraint on the antiquity of anaerobic oxidation of methane: Late Pennsylvanian seep limestones from southern Namibia. Geology 36: 543-546. 


\section{Molecular fossils indicating the origin of filaments in Messinian evaporites [talk]}

Lars Hoffmann ${ }^{1}$, Daniel Birgel ${ }^{1}$, Simone Ziegenbalg${ }^{1}$, Jean-Marie Rouchy² \& Jörn Peckmann ${ }^{1}$

${ }^{1} M A R U M$ - Zentrum für Marine Umweltwissenschaften, Universität Bremen, Bremen, Germany;

E-mail:lars.hoffmann@uni-bremen.de,dbirgel@uni-bremen.de,simone.ziegenbalg@uni-bremen.de \& peckmann@uni-bremen.de

${ }^{2}$ UMR CNRS 5143, Laboratoire de Géologie, Muséum National d'Histoire Naturelle, Paris, France; E-mail:rouchy@mnhn.fr

The Messinian salinity crisis resulted in deposition of evaporitic sediments in the Mediterranean. Filamentous textures are a common feature in gypsum and carbonate rocks from various Messinian evaporitic sequences in this region. These filaments have been petrographically described earlier and were interpreted either as remains of algal mats (Vai \& Ricci Lucchi 1977) or cyanobacteria (Rouchy \& Monty 1981). Similar filamentous textures were identified in the Messinian Calcare di Base Formation in northern Calabria, which were interpreted as faecal pellets of brine shrimps (Guido et al. 2007).

The aim of this study is to apply lipid biomarker analyses to elucidate the origin of these filamentous textures. Gypsum and carbonate samples containing filamentous textures were extracted. In a second step, gypsum and carbonate crystals were dissolved and another extraction followed in order to recover lipids preserved in the crystalline lattices. Dissolution of carbonate and gypsum enables us to determine whether these lipid biomarker patterns represent conditions during evaporite formation. Preliminary results of samples from different locations of the Mediterranean will be presented.

\section{References}

Guido, A.; Jacob, J.; Gautret, P.; Laggoun-Défarge, F.; Mastandrea, A. \& Russo, F. 2007. Molecular fossils and other organic markers as palaeoenvironmental indicators of the Messinian Calcare di Base Formation: normal versus stressed marine deposition (Rossano Basin, northern Calabria, Italy). Palaeogeography, Palaeoclimatology, Palaeoecology 255: 265-283.

Rouchy, J.-M. \& Monty, C. L. V. 1981. Stromatolites and cryptalgal laminites associated with Messinian gypsum of Cyprus. In: Monty, C. L. V. (ed.): Phanerozoic Stromatolites. pp. 155-180; Berlin (Springer).

Vai, J. B. \& Ricci Lucchi, F. 1977. Algal crusts, autochthonous and clastic gypsum in a cannibalistic evaporite basin: a case study from the Messinian of Northern Apennines. Sedimentology 24: 211-244. 


\title{
The Distribution and Morphological Variability of Hamelin Pool Stromatolites, Shark Bay, Western Australia - New Light on a Fifty- Year Old Riddle [talk]
}

\author{
Gumpei Izuno ${ }^{1}$, Robert V. Burne ${ }^{2} \&$ Murray T. Batchelor ${ }^{3}$ \\ ${ }^{1}$ Coastal Environment Laboratory, Department of Socio-Cultural Environmental Studies, Graduate \\ School of Frontier Sciences, The University of Tokyo, Japan; E-mail:__izuno@coastal.t.u-tokyo.ac.jp \\ ${ }^{2}$ Research School of Earth Sciences, The Australian National University, Canberra, ACT, Australia; \\ E-mail:robert.burne@anu.edu.au
}

${ }^{3}$ Department of Theoretical Physics, Research School of Physical Sciences \& Engineering and Mathematical Sciences Institute, The Australian National University, Canberra, ACT, Australia; E-mail:murray.batchelor@anu.edu.au

It is now more than fifty years since Richard Chase recognized stromatolites fringing the shores of Hamelin Pool, Western Australia. They were the first convincing modern analogues of the "stromatoliths" described by Kalkowsky (1908) to be discovered. The Hamelin Pool stromatolites show great morphological variation and extend from the high intertidal zone to subtidal depths of about 2 metres. Analysis of variation in stromatolite height shows that the tallest structures occur in the shallow subtidal zone, and that stromatolite relief decreases toward both the upper intertidal zone and toward the deeper subtidal limit of occurrence. Stromatolites at similar depths all have similar relief. The shape of the stromatolites also varies consistently depending on the position relative to present sea-level. Flat forms dominate the high intertidal zone, cauliflower-shaped stromatolites are found in the lower intertidal zone, columnar-shapes dominate in shallow subtidal environments and the deepest examples are all small domes. Several authors (Logan et al. 1974; Playford 1990; Golubic 1992) have related variation in stromatolite shape to the occurrence of different types of microbial communities at different elevations. Burne (1991/92) suggested that stromatolite growth was initiated in subtidal environments, and the present distribution is the result of falling sea levels and modification by intertidal microbial communities. In this study we have (a) precisely surveyed the distribution of stromatolites in Hamelin Pool, and (b) modelled stromatolite growth variation by stipulating depth limits for stromatolite growth; suggested stromatolite growth rates; likely rate and direction of sea-level change; and period of time of that conditions for stromatolite growth have existed. We conclude that the morphological variation of stromatolites in Hamelin Pool can be accounted for by a model in which principal growth occurs only between mean low sea level and a depth of 2 metres, growth rate is $5 \mathrm{~mm} /$ decade, conditions suitable for stromatolite growth commenced 1,500 years ago, and relative sea level has fallen by 2 metres in the past 4000 years. A careful review of the localities described by Meischner (1994) has found no evidence to support his conclusion that some of the Hamelin Pool stromatolites are of Pleistocene age. 


\section{References}

Burne, R. V. 1991-92. Lilliput's Castles: Stromatolites of Hamelin Pool. Landscope 7 (2): 34-40.

Golubic S. 1992. Stromatolites of Shark Bay. In: Margulis, L. \& Olendzenski, L. (eds.): Environmental Evolution: Effects of the Origin and Evolution of Life on Planet earth. pp. 131-147; Cambridge (MIT Press).

Kalkowsky, E. 1908. Oolith und Stromatolith im norddeutschen Buntsandstein. Zeitschrift der deutschen geologischen Gesellschaft 60: 68-125.

Logan, B. W.; Hoffman, P. \& Gebelein, C. D. 1974. Algal Mats, Cryptalgal Fabrics, and Structures, Hamelin Pool, Western Australia. In: Logan, B. W.; Read, J. F.; Hagan, G. M.; Hoffman, P.; Brown, R. G.; Woods, P. J. \& Gebelein, C. D. (eds.): Evolution and Diagenesis of Quaternary Carbonate Sequences, Shark Bay, Western Australia. The American Association of Petroleum Geologists, Tulsa, Oklahoma, Memoir 22: 140-194.

Meischner, D. 1994. Stromatolites in Shark Bay, Western Australia: Interglacial and Subtidal Origins. In: Awramik, S. W. (ed.): Death Valley International Stromatolite Symposium, Laugblin, Nevada, U.S.A., 15-17 Oct 1994. Abstract with Program. p. 47.

Playford, P. E. 1990. Geology of the Shark Bay Area, Western Australia. In: Berry, P. F.; Bradshaw, S. D. \& Wilson, B. R. (eds.): Research in Shark Bay. pp. 13-31; Perth (Western Australian Museum).

\section{Bacterial colonies biomineralization as a model of integrated active- passive biomineralization processes to understand the formation of lithifying mats [poster]}

Fadwa Jroundi¹, Concepción Jiménez-Lopez ${ }^{1}$, Kaoutar Ben Chekroun ${ }^{1}$, Manuel Rodríguez-Gallego ${ }^{2}$, José Maria Arias ${ }^{1} \&$ Maria Teresa Gonzalez-Muñoz ${ }^{1}$

${ }^{1}$ Departamento de Microbiología, Facultad de Ciencias, Universidad de Granada, Granada, Spain;

E-mail:fadwa@ugr.es,jmarias@ugr.es_rmgonzale@goliat.ugr.es

${ }^{2}$ Departamento de Mineralogía y Petrología, Facultad de Ciencias, Universidad de Granada, Granada, Spain; E-mail:mrgalleg@goliat.ugr.es

Stromatolites are petrified microbial mats, defined as "organosedimentary structures predominantly accreted by sediment trapping, binding, and/or in situ carbonate precipitation as a result of the growth and metabolic activity of microorganisms" (Walter 1976). Heterotrophic bacteria can contribute to $\mathrm{CaCO}_{3}$ precipitation since their metabolic activity induces chemical changes in the media by different metabolic pathways (Riding 2000). Understanding the mechanisms of bacterial colony calcification could be the first step to understand the lithification process of microbial mats. In this regard, Myxococcus xanthus, an heterotrophic bacterium effective producer of calcium carbonate (Rodriguez-Navarro et al. 2003; Ben Chekroun et al. 2004), was chosen to investigate the mechanisms leading to the calcification of colonies using two different culture media, M-3 and CC. Metabolic activity in both media releases $\mathrm{NH}_{3}$ and $\mathrm{CO}_{2}$ that increases the $\mathrm{pH}$ and alkalinity leading to $\mathrm{CaCO}_{3}$ precipitation. At time intervals, ranging from $24 \mathrm{~h}$ to 30 days, glutaraldehide-fixed colonies were harvested to study the mineralization pro- 
cess by electron microscopy and XRD analyses. Interestingly, two calcification patterns were observed. The calcification in both media occurred first on the borders and with time, calcified areas extended to the inner of the colony until crystals cover the whole colony in M-3, while in CC the calcification was restricted to defined concentric rings. XRD analyses revealed the precipitation of vaterite and vaterite/calcite in M-3 and $\mathrm{CC}$ media, respectively. $\mathrm{CaCO}_{3}$ polymorph selection in each medium is related to the supersaturation conditions in the colony, being that the result of the initial saturation level of the culture media (higher in M-3), the metabolic activity of $M$. xanthus, the supersaturation gradients along the colony created by the bacterial metabolic activity, and the precipitation events. These saturation gradients along the colony end up in different patterns of colony calcification that may serve to recognize saturation levels of the natural environments in which lithifying mats formed.

\section{References}

Ben Chekroun, K.; Rodriguez-Navarro, C.; Gonzalez-Muñoz, M. T.; Arias, J. M.; Cultrone, G. \& Rodriguez-Gallego, M. 2004. Precipitation and growth morphology of calcium carbonate induced by Myxococcus xanthus: Implications for recognition of bacterial carbonates. Journal of Sedimentary Research 74: 868-876.

Riding, R. 2000. Microbial carbonates: the geological record of calcified bacterial-algal mats \& biofilms. Sedimentology 47: 179-214.

Rodriguez-Navarro, C.; Rodriguez-Gallego, M.; Ben Chekroun, K. \& Gonzalez-Muñoz, M. T. 2003. Conservation of ornamental stone by Myxococcus xanthus-induced carbonate biomineralization. Applied and Environmental Microbiology 69: 2182-2193.

Walter, M. R. 1976. Introduction. In: Walter, M. R. (ed.): Stromatolites. pp. 1-3; Amsterdam (Elsevier).

\section{Timing and processes of a banded calcite travertine in Crystal Geyser, Utah [talk]}

Akihiro Kano ${ }^{1}$, Tomoyo Okumura ${ }^{2}$, Chiduru Takashima ${ }^{1} \&$ Toshihiko Shimamoto $^{2}$

${ }^{1}$ Division of Evolution of Earth Environment, Graduate School of Social and Cultural Studies, Kyushu University, Fukuoka, Japan; E-mail: kano@scs.kyushu-u.ac.jp \& ctakashima@scs.kyushu-u.ac.jp

${ }^{2}$ Department of Earth and Planetary Systems Science, Graduate School of Science, Hiroshima University, Higashi-hiroshima, Japan; E-mail: ok.tomy@hiroshima-u.ac.jp@shima007@hiroshima-u.ac.jp

Geochemical and petrological analyses were performed for a banded travertine in Crystal Geyser in the Paradox Basin (central Utah, Unites States), which was created at an oil-exploration well drilled in 1930s. The geyer discharges calcareous water every 16 hours (in August, 2007) and develops a travertine mound of $100 \mathrm{~m}$ in diameter beside the Green River. Each discharge event consists of a series of weak spouts (called bubbling) lasting 3-5 hours and the following intense eruption 
for 30-90 minutes long, and all together $\sim 1000 \mathrm{~m}^{3}$ of water was discharged from the geyser. The water flows on the mound surfaces during the discharge event, but dries out in a few hours.

The water becomes highly supersaturated with $\mathrm{CaCO}_{3}$ by active $\mathrm{CO}_{2}$-degassing and deposits a substantial amount of calcite during flowing on the travertine mound. The travertine deposits, especially ones on the distal part of the mound, normally exhibit sub-mm scale lamination consisting of bands of fine-grained particles encased in sparitic calcite crystals. The bands are accompanied with photosynthetic algae and cyanobacteria. Four-days observation of the deposit stained by Alizarin Red S identified that only two bands were developed after the staining. Therefore, the banding was not controlled by temporal water discharge from the geyser. Petrological observation indicates that timing of the band formation likely corresponds to the discharge event happened in daytime.

Fine-grained calcites of the band were detrital particles trapped and bound by glutinous substances secreted by photosynthetic microorganisms that require both water and light. During the night, crystalline calcite was formed mainly by inorganic precipitation from the discharged water. These processes are basically same as those in daily banding observed in a calcite travertine in southwestern Japan (Takashima \& Kano). This study confirms importance of biological processes in formation of the stromatolitic lamination, even for travertines that grow with an extraordinary rate in highly supersaturated water.

Acknowledgements: We thank Shuichiro Gemba for joining the fieldwork, Hayami Ishisako and Yasuhiro Shibata for EPMA analysis and thin-section preparation. This study was supported by Japan Society for the Promotion of Science and Japanese Ministry of Education and Science.

\section{References}

Takashima, C. \& Kano, A. in press. Microbial processes forming daily lamination in a stromatolitic travertine. Sedimentary Geology.

\section{Modern and sub-recent carbonate microbialites from the alkaline crater lake Alchichica, Mexico [talk]}

Józef Kazmierczak ${ }^{1}$, Stephan Kempe ${ }^{2}$, Purificatión López-García ${ }^{3}$, Rosaluz Tavera $^{4}$, Barbara Kremer ${ }^{1} \&$ David Moreira $^{3}$

\footnotetext{
${ }^{1}$ Institute of Paleobiology, Polish Academy of Sciences, Warszawa, Poland; E-mail: jkaz@twarda.pan.pl \&kremen@twarda,pan.pl

${ }^{2}$ Institute for Applied Geosciences, TU Darmstadt, Darmstadt, Germany; E-mail: kempe@geo.tudarmstadt.de
} 
${ }^{3}$ Unité d'Ecologie, Systématique \& Evolution, CNRS UMR 8079, Université Paris-Sud, Orsay, France; E-mail:puri.lopę@u-psud.fr w david.moreira@u-psud.fr

${ }^{4}$ Ecology and Natural Resources Department, School of Sciences, UNAM, México City, México; E-mail:rts@hp.fcienias.unam.mx

Structure and growth processes of modern and subfossil carbonate cyanobacterial microbialites (particularly stromatolites) from the alkaline crater lake Alchichica (Puebla State, Mexico) (Vilaclara et al. 1993; Alcocer \& Hammer 1998) have been studied in 2006 and 2007 in the context of its hydrochemistry and carbonate system evolution.

Alchichica is a crater lake (Fig. 1a) located in the Cuenca de Oriental region $\left(19^{\circ} 24^{\prime} \mathrm{N} 98^{\circ} 24^{\prime} \mathrm{W}\right)$, in the Central Mexican Plateau, at an altitude of 2,300 m above sea level. Alchichica is the deepest of the natural Mexican lakes (max. depth $64 \mathrm{~m}$, mean depth $38.6 \mathrm{~m}$ ), with an area of $1.81 \mathrm{~km}^{2}$. The lake is brackish (TDS $\left.8763 \pm 67 \mathrm{mg} \mathrm{L}^{-1}\right)$, alkaline ( $\left.\mathrm{pH} 8.88 \pm 0.008\right)$, with a chemistry dominated by $\mathrm{Na}$ plus $\mathrm{Mg}$ and $\mathrm{Cl}$ plus $\mathrm{HCO}_{3}$ (Table 1). Due to winter mixing (temperature ranged in June from $19.8-13.8^{\circ} \mathrm{C}$ between the surface and the bottom), the chemistry of the water is well mixed. In June the water was depleted in oxygen (but not anaerobic) and enriched in nutrients towards the bottom. The lake is supplied with precipitation and ground water infiltrating from higher ground around the lake basin towards the east. Since this area is partly composed of calcareous Cretaceous deposits, the ground waters infiltrating lake Alchichica are enriched in $\mathrm{Ca}^{2+}$ and $\mathrm{HCO}_{3}$. This could be the source of the $\mathrm{CaCO}_{3}$ for the massive microbialites occurring around the lake (Tavera \& Komarek 1996), while the magnesium is derived from the weathering of the volcanics.

Table 1. Means and standard deviations of dominant ions in Lake Alchichica of eight samples taken $19^{\text {th }}$ and $20^{\text {th }}$ June 2007, from depths of $0,10,20,26,30,40,50$ and $60 \mathrm{~m}$.

$\begin{array}{llllll}\mathrm{Cl} \mathrm{meq} / 1 & \mathrm{Alk} \mathrm{meq} / 1 & \mathrm{SO}_{4} \mathrm{meq} / 1 & \mathrm{Br} \mathrm{meq} / 1 & \mathrm{NO}_{3} \mathrm{meq} / 1 & \mathrm{PO}_{4} \mathrm{meq} / 1 \\ 87.3 \pm 0.75 & 30.9 \pm 0.35 & 16.73 \pm 0.15 & 0.10 \pm 0.0004 & 0.0061 \pm 0.0042 & 0.005 \pm 0.5 \\ \mathrm{Na} \text { meq/1 } & \mathrm{Mg} \mathrm{meq} / 1 & \mathrm{~K} \text { meq/1 } & \mathrm{Ca} \mathrm{meq} / 1 & \mathrm{Li} \mathrm{meq} / 1 & \mathrm{O}_{2} \mathrm{mg} / 1 \\ 100.5 \pm 0.74 & 35.61 \pm 0.49 & 5.32 \pm 0.16 & 0.735 \pm 0.17 & 0.26 \pm 0.098 & 6.5 \text { to } 0.2\end{array}$

Due to the recent lowering of the lake level, the product of the mineralization of the cyanobacterial mats is visible as weathered masses of carbonate mounds and crusts extending up to a few meters above the lake level (Fig. 1b, 1d, 1e). According to earlier data (Vilaclara et al. 1993; Ramirez-Garcia \& Vazquez-Gutierrez 1989) and our echosounding and SCUBA diving observations, the cyanobacterial microbialites occur in the lake to the depth of $\sim 15 \mathrm{~m}$ giving opportunity for sampling microbialites along their entire bathymetric profile. 

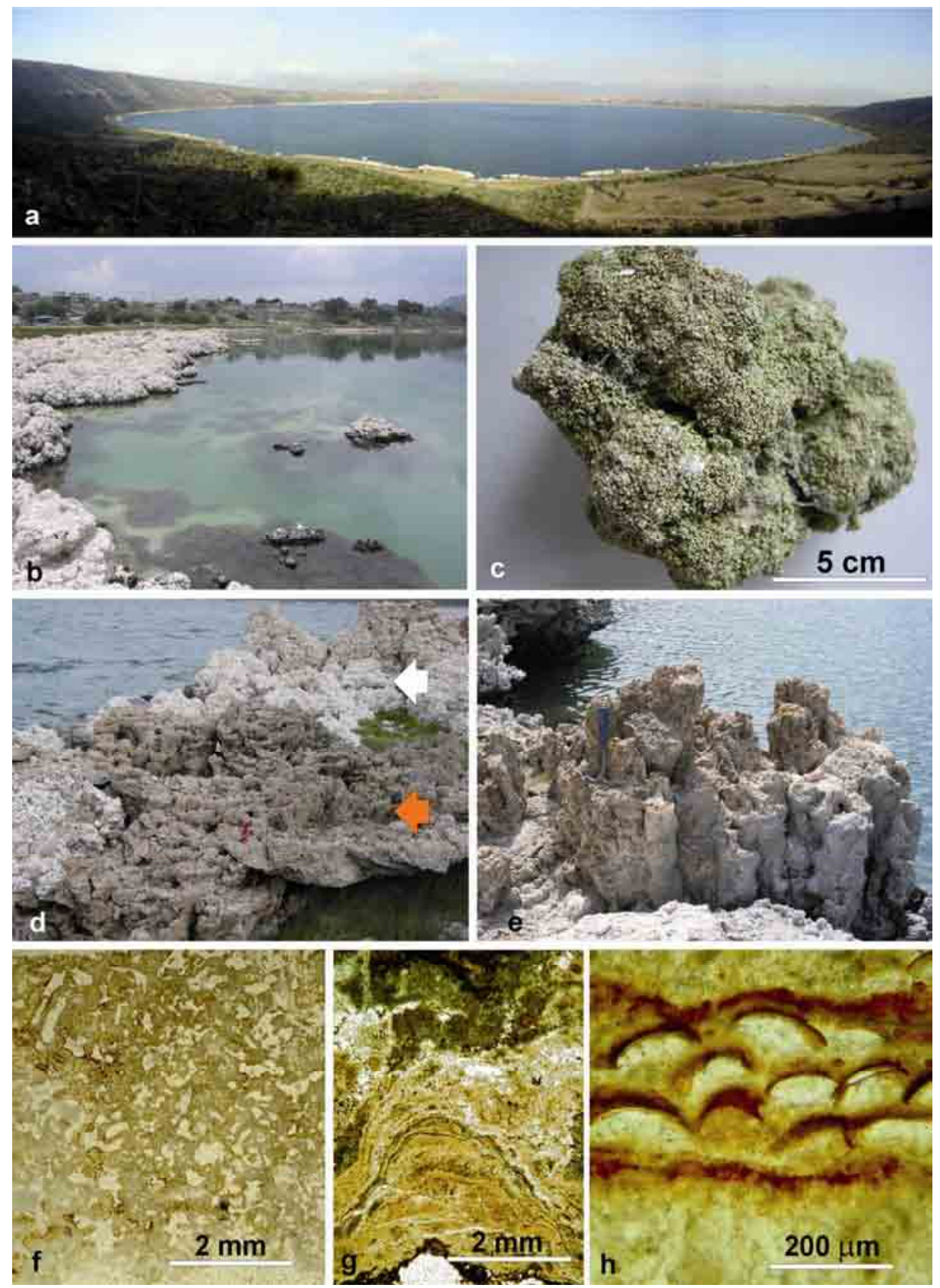

Fig. 1. Lake Alchichica microbialites: (a) General view of the lake; (b) Emerged subfossil and living underwater microbialites; (c) living microbialite sample from c. $8 \mathrm{~m}$ water depth; (d) Emerged older (orange arrow) and younger (white arrow) microbialite generations; (e) chimney-like older generation of microbialites; (f-h) Examples of microbialite microfabrics: (f) fenestrate, (g) laminated, (h) cystose. 
The living cyanobacterial mats (Fig. 1c) are composed of a very diverse community of filamentous and coccoid cyanobacteria among which members of the orders Nostocales, Chroococcales, Oscillatoriales, Pleurocapsales and the recently discovered genus Acaryochloris have been identified on a morphological and molecular basis.

Two generations of carbonate microbialites have been identified: (i) older, in the form of brownish masses of aragonite often in the form of candelabra- or chimney-like systems (Fig. 1d, orange arrow and 1e), and (ii) younger, in the form of whitish, dome-like, silicified masses of magnesite with an admixture of calcite (Fig. 1b, and 1d, white arrow). Three main types of microfabric characterize the Alchichica microbialites: (1) fenestrate (Fig. 1f), laminated (Fig. 1g), and cystose (Fig. 1h). XRD analyses of minerals precipitated in association with the living cyanobacterial mats indicate predominance of hydromagnesite $\left[\mathrm{Mg}_{5}\left(\mathrm{CO}_{3}\right)_{4}(\mathrm{OH})_{2}\right.$ - $\left.4\left(\mathrm{H}_{2} \mathrm{O}\right)\right]$ with some addition of huntite $\left[\mathrm{CaMg}_{3}\left(\mathrm{CO}_{3}\right)_{4}\right]$. The hydromagnesite is subsequently transforming into magnesite and undergoes massive silicification (chertification) obliterating the primary texture of the carbonate. This process has a bearing on understanding the abundance of dolomites and cherts (or chertified carbonates) deposited in the early Precambrian ocean, which, according to the "Soda Ocean Hypothesis (SOH)" of Kempe \& Degens (1985), was highly alkaline $(\mathrm{pH}>9)$. The chemical composition of Alchichica and other recent alkaline lakes (soda lakes) occurring dominantly in volcanic areas can serve as geochemical analogues. The abundance of carbonate microbialites in lake Alchichica gives additional supports for the $\mathrm{SOH}$, showing that modern alkaline environments sustain in situ calcifying microbial mats generating biosedimentary structures similar to those known from Precambrian deposits.

\section{References}

Alcocer, J. \& Hammer, U. T. 1998. Saline lake ecosystems of Mexico. Aquatic Ecosystem Health \& Management 1 (3): 291-315.

Kempe, S. \& Degens, E. T. 1985. An early soda ocean? Chemical Geology 53: 95-108.

Ramírez-García, P. \& Vázquez-Gutiérrez, F. 1989. Contribuciones al estudio limnobotánico de la zona litoral de seis lagos cráter del estado de Pueblo, México. Anales del Instituto de Ciencias del Mary Limnologia 16 (1): 1-16.

Tavera, R. \& Komarek, J. 1996. Cyanoprokaryotes in the volcanic lake of Alchichica, Puebla State, Mexico. Algological Studies 83: 511-538.

Vilaclara, G.; Chávez, M.; Lugo, A.; Gonzáles, H., \& Gaytán, M. 1993. Comparative description of crater-lakes basic chemistry in Puebla State, Mexico. Verbandlungen der Internationalen Vereinigung für Limnologie 25: 435-440. 


\section{Long term diagenetic fate of $\mathrm{Fe}$ mineral/cell organic matter aggregates formed during the deposition of Precambrian Banded Iron Formations [talk]}

Inga Köhler, Nicole R. Posth \& Andreas Kappler

Geomicrobiology, Center for Applied Geosciences, University of Tuebingen, Tuebingen, Germany; E-mail: inga.koeblen@uni-tuebingen.de

Banded Iron Formations (BIFs) are Precambrian sedimentary deposits of alternating iron oxide and silica mineral layers. Despite decades of intensive research the formation of these iron ores remains largely a mystery. The first BIF formations date back to about 3.5-3.8 billion years and little is known about this early period in earth's history, in particular about the presence of molecular oxygen, $\mathrm{O}_{2}$. Nothing comparable exists on modern earth that could serve as an analogue. Phototrophic iron(II)-oxidizing bacteria recently have been discovered which might represent an alternative hypothesis to early BIF formation in the absence of $\mathrm{O}_{2}$ (Widdel et al. 1993). These bacteria could have oxidized ferrous iron from hydrothermal vents to ferric iron that slowly settled down to submerged basins together with biomass formed during the microbial oxidation (Kappler et al. 2005). After sedimentation of the cell-mineral aggregates, a diagenetic and/or metamorphic transformation set in that altered the original sediments, sometimes beyond recognition. It has never been attempted to experimentally simulate these transformation processes, although this potentially could shed light on the question whether cyanobacterial $\mathrm{O}_{2}$ or anoxygenic photosynthetic $\mathrm{Fe}(\mathrm{II})$-oxidizing bacteria oxidized the Fe(II) of early Earth BIFs. To bridge this gap we have carried out diagenesis simulation experiments of biotically and abiotically formed iron minerals and mineral-organic matter associations in order to distinguish the two scenarios. Experiments were run for different time periods and $\mathrm{P} / \mathrm{T}$ conditions of $1.2 \mathrm{kbar}$ and $170^{\circ} \mathrm{C}$. The mineral transformation products were analyzed by reflected light microscopy and $\mu$-XRD and showed the formation of hematite, siderite and magnetite with different crystal structures and defined spatial arrangement of these different minerals. Furthermore formation of significant amounts of elemental carbon and methane was observed. We also started incubating cell-mineral aggregates of phototrophic Fe(II)-oxidizing strains under high $\mathrm{P} / \mathrm{T}$ conditions and analyzing the organic remains as potential biomarkers and organic fossils. The results from these diagenesis experiments will be compared with data of BIF samples from South Africa, Canada, and Greenland with particular attention to the identity of minerals produced, their association with each other and the way in which they are associated. Apart from providing new insights into the formation of BIF, our study will further improve our general understanding of iron mineral transformation and iron biogeochemistry in ancient as well as in modern environments. 


\section{References}

Kappler, A.; Pasquero, C.; Konhauser, K. O. \& Newman, D. K. 2005. Deposition of banded iron formations by anoxygenic phototrophic Fe(II)-oxidizing bacteria. Geology 33 (11): 865-868.

Widdel, F.; Schnell, S.; Heising, S.; Ehrenreich, A.; Assmus, B. \& Schink, B. 1993. Ferrous iron oxidation by anoxygenic phototrophic bacteria. Nature 362: 834-836.

\section{Specific trace element signatures in microbially induced mineral precipitates from the tunnel of Äspö/Sweden [poster]}

Jens Kurz ${ }^{1}$, Klaus Simon ${ }^{2}$, Christine Heim ${ }^{1}$, Burkhard Schmidt ${ }^{3}$, Joachim Reitner ${ }^{1}$ \& Volker Thiel ${ }^{1}$

${ }^{1}$ Geowissenschaftliches Zentrum der Universität Göttingen, Abt. Geobiologie, Göttingen, Germany;

E-mail:jens.kur:@gmx.de,cheim@gwdg.de,jreitne@gwdg.de_v vthiel@gwdg.de

${ }^{2}$ Geowissenschaftliches Zentrum der Universität Göttingen, Abt. Geochemie, Göttingen, Germany;

E-mail:ksimon@gwdg.de

${ }^{3}$ Geowissenschaftliches Zentrum der Universität Göttingen, Abt. Experimentelle und Angewandte Mineralogie, Göttingen, Germany; E-mail: burkhard.schmidt@geo.uni-goettingen.de

The tunnel of Äspö is located near Oskarshamn in the southeast of Sweden and serves as a testing environment for the disposal of nuclear waste. The tunnel is $3600 \mathrm{~m}$ long and extends down to a depth of $450 \mathrm{~m}$ into Proterozoic granitic rocks. $1127 \mathrm{~m}$ from the tunnel entrance, $160 \mathrm{~m}$ below the Baltic Sea floor (Anderson \& Pedersen 2003), a pond has established beneath a fluid source. The pond contains microbial mats dominated by the iron-oxidizing bacterium Gallionella ferruginea and sulphate-reducing bacteria (SRB). Macroscopically, prominent occurrences of these microorganisms are characterized by ochre and black colours, respectively. High concentrations of trace elements like REE have been reported in association with bacteriogenic iron oxides from Gallionella (Anderson \& Pedersen 2003; Ferris et al. 1999) and in the extracellular polymeric substances (EPS) of SRB (Beech \& Cheung 1995). In this study, five syringe cores of bacterial mats from the pond were studied for accumulations and distribution patterns of trace elements. Three of these cores contained horizontally laminated ochre material with dark streaks, one core contained only ochre and another core only black material. The cores were segmented according to the colour zonation into 28 samples. The samples were freeze-dried and analyzed with inductively coupled plasma - mass spectrometry (ICP-MS), inductively coupled plasma - optical emission spectroscopy (ICP-OES), CNS elemental analyzer, and Raman spectroscopy. The results show that trace elements in general are very highly enriched in the microbial matter (up to a thousand times higher than in chondrite c1). As shown in Fig. 1, the element patterns were similar in the streak parts and in the ochre parts, with Mn, Sr, Mo, W and U showing somewhat higher abundance in 
the further, and P, Ti, and $\mathrm{Zn}$ in the latter. Factor analysis of all measured elements using Statistica 6.0 revealed a completely different element distribution for the black core. Compared to the ochre and streak samples, the black core samples are lower in $\mathrm{Na}, \mathrm{P}, \mathrm{Mn}, \mathrm{Fe}, \mathrm{Sr}, \mathrm{W}$ and heavy REE, but significantly higher in $\mathrm{Mg}, \mathrm{Ca}$, Ti, Co, Ni, Cu, Zn, Cd, Rb, Cs, Pb and light REE. Thus, although the feeder fluid is the same for the ochre, the streak and the black parts, each mat type displayed a distinctive trace element signature. Microbial EPS in general possess carboxyl and phosphate groups that may act as binding sites for trace elements (Hanert 2002). Whereas EPS were reported to bind enormous amounts of heavy metals like La (Merroun et al. 2003), the large difference in the trace element signatures is difficult to explain only by EPS sorption. It is therefore suggested that these signatures were caused by biologically induced mineralization in oxidizing or reducing environments where iron oxides or sulphides precipitate, respectively (Watson et al. 1995).

\section{Multielement analysis based on average values}

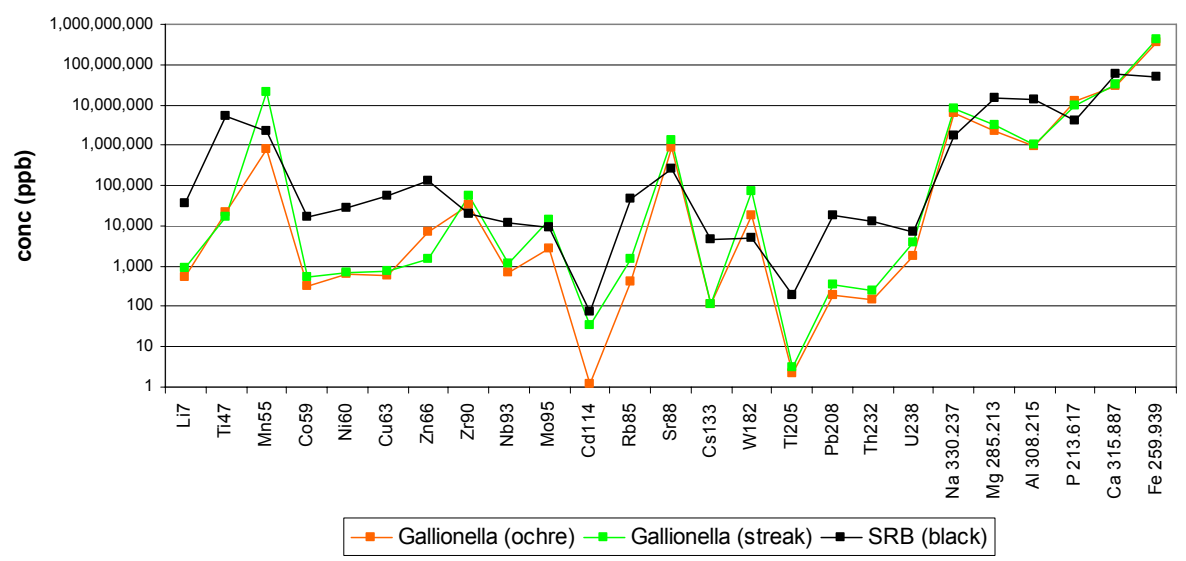

Fig. 1. ICP-MS and ICP-OES multielement analysis of the three mat types (average values from 4 ochre, 4 streak and 2 black end member samples).

\section{References}

Anderson, C. R. \& Pedersen, K. 2003. In situ growth of Gallionella biofilms and partitioning of lanthanides and actinides between biological material and ferric oxyhydroxides. Geobiology 1 (2): 169-178.

Beech, I. B. \& Cheung, C. W. S. 1995. Interactions of exopolymers produced by sulphate-reducing bacteria with metal ions. International Biodeterioration \& Biodegradation 35 (1-3): 59-72.

Ferris, F. G.; Konhauser, K. O.; Lyvén, B. \& Pedersen, K. 1999. Accumulation of metals by bacteriogenic iron oxides in a subterranean environment. Geomicrobiology Journal 16 (2): 181-192.

Hanert, H. H. 2002. Bacterial and chemical iron oxide deposition in a shallow bay on Palaea Kameni, Santorini, Greece: microscopy, electron probe microanalysis, and photometry of in situ experiments. Geomicrobiology Journal 19 (3): 317-342. 
Merroun, M. L.; Chekroun, K. B.; Arias, J. M. \& González-Muñoz, M. T. 2003. Lanthanum fixation by Myxococcus xanthus: cellular location and extracellular polysaccharide observation. Chemosphere 52: 113-120.

Watson, J. H. P.; Ellwood, D. C.; Deng, Q.; Mikhalovsky, S.; Hayter, C. E. \& Evans, J. 1995. Heavy metal adsorption on bacterially produced FeS. Minerals Engineering 8 (10): 1097-1108.

\section{Nanoscale evidence for microbial mineralization of $2.7 \mathrm{Ga}$ stromato- lites [talk]}

Kevin Lepot ${ }^{1}$, Karim Benzerara ${ }^{1,2}$, Gordon E. Brown ${ }^{3} \&$ Pascal Philippot $^{1}$

${ }^{1}$ Equipe Geobiosphère Actuelle et Primitive, Institut de Physique du Globe de Paris, Paris, France;

E-mail:lepot@ipgp.jussieu.fr@obhilippot@ipgp.jussieu.fr

${ }^{2}$ Institut de Minéralogie et de Physique des Milieux Condensés, Paris, France; E-mail:

karim.benzerara@impmc.jussieu.fr

${ }^{3}$ Department of Geological \& Environmental Sciences, Stanford University, Stanford, CA, USA \&

Stanford Synchrotron Radiation Laboratory, Menlo Park, USA; E-mail: gordon.brown@stanford.edu

The macroscale morphology of Archean stromatolites has been used as evidence of early microbial ecosystems. But as Archean stromatolites only rarely contain fossil microbes, their biogenicity is tacitly assumed on the basis of macroscopic morphological comparisons with modern structures. Biogenetic definitions, however, require microscopic examination of suspected stromatolites. We obtained an unique collection of pristine samples from a diamond drillhole that intersected the 2.7 Ga Tumbiana Formation, Australia (Pilbara Drilling Project) (Van Kranendonk et al. 2006). We report the occurrence of micron-sized globules of organic carbon intimately associated with the host micritic carbonate. Scanning Transmission Xray Microscopy (STXM) analysis revealed that these organic globules are composed of organic carbon with aromatic, aliphatic and carboxyl functional groups. High Resolution Transmission Electron Microscopy (HRTEM) analysis revealed that the organic material occurs in intimate association with clustered, $50-200 \mathrm{~nm}$ rounded bodies of aragonite (Lepot et al. 2008). These nano-aragonite aggregates show striking similarities with nano-carbonate spheroids associated with microbial cells and polymers in modern microbialites. The organic globules are moreover cell-like. They might have been preserved owing to their encapsulation in carbonates. The organic preservation pathway of these globules will be discussed based on our systematic study of the distribution and composition of the organic matter in the Tumbiana stromatolites.

Our results indicate that Tumbiana stromatolites were likely formed via in-situ microbial lithification. They also extend the geologic record of aragonite back more than 2,300 million years. 


\title{
References
}

Lepot, K.; Benzerara, K.; Brown, G. E. \& Philippot, P. 2008. Microbially influenced formation of 2,724 million years old stromatolites. Nature Geoscience 1: 118-121.

Van Kranendonk, M. J.; Philippot, P. \& Lepot, K. 2006: The Pilbara Drilling Project: c. 2.72 Ga Tumbiana Formation and c. 3.49 Ga Dresser Formation, Pilbara Craton, Western Australia. Geological Survey of Western Australia, Record 2006/14: 25 pp.

\section{A Multiproxy Approach to Understanding the Depositional Environ- ment and Mineralization Processes of the Messinian Calcare di Base Formation (Northern Calabria, Italy) [talk]}

\author{
Adelaide Mastandrea, Adriano Guido, Fabio Tosti \& Franco Russo \\ Dipartimento di Scienze della Terra, Università della Calabria, Rende (CS), Italy; E-mail: \\ a.mast@unical.it,.aguido@unical.it,fabiotosti@gmail.comßf.russo@unical.it
}

A multidisciplinary approach has been carried out on the Messinian Calcare di Base $(\mathrm{CdB})$ Formation with the aim of understanding the depositional conditions of these enigmatic carbonate sediments. The $\mathrm{CdB}$ has been interpreted by several Authors as evaporitic or diagenetic limestone (Bellanca et al. 2001; Decima et al. 1988; Rouchy \& Caruso 2006).

The research has been developed through: (a) transmitted light and fluorescence observations, (b) SEM-EDS analyses, (c) organic petrography and geochemistry analyses (palynofacies, Rock-Eval pyrolysis and Gas Chromatography/Mass Spectrometry), and (d) Rare Earth Elements contents with ICP-MS.

Optical and SEM observations and energy-dispersive X-ray spectrometer (EDS) microanalyses put in evidence that the $\mathrm{CdB}$ sediments are mainly constituted of peloidal micrites, still preserved in its original aragonitic mineralogy. The microfacies is characterized by variably sized irregular peloids forming clots with antigravitative fabric, in which fecal pellets are patchily dispersed. The peloidal micrite shows thrombolitic microfacies (Fig. 1), very rich in organic matter content as it is indicated by its bright epifluorescence. The organic matter follows the morphological pattern of peloids.

Palynological observations revealed an abundant and diversified community of biota, which are documented by amorphous organic matter (of algal or bacterial origin), vascular plants, algae, bacteria and arthropod exoskeletons. Arthropods (copepods) could have been the main producers of the fecal pellets. These data have been confirmed by both global and molecular biogeochemical data. RockEval pyrolysis revealed a transitional composition between types II and III kerogen, suggesting a mixture of marine and terrigenous organic matter. n-Alkanes distribution enabled the distinction of three main biological signatures: algal (mode 
in $n \mathrm{C} 18-n \mathrm{C} 20$ ), terrestrial (mode in $n \mathrm{C} 27-n \mathrm{C} 29$ ), and bacterial (mode in $n \mathrm{C} 26-n \mathrm{C} 28$ with no odd-even carbon number predominance). These different origins have been also supported by the short chain $(<\mathrm{C} 22)$ of fatty acids and the predominance of C27 steranes (algal signature), hopanes, branched n-alkanes, and unsatured fatty acids (bacterial input). Whereas the long chain ( $>$ C22) of fatty acids indicates a vascular plant input. The evidence of a rich community of organisms together with the absence of hopanoids, typical of anoxic and/or hypersaline sediments (isorenieratane, pentakishomohopanoids and gammacerane), indicate a marine sedimentation environment for the $\mathrm{CdB}$ (Guido et al. 2003).

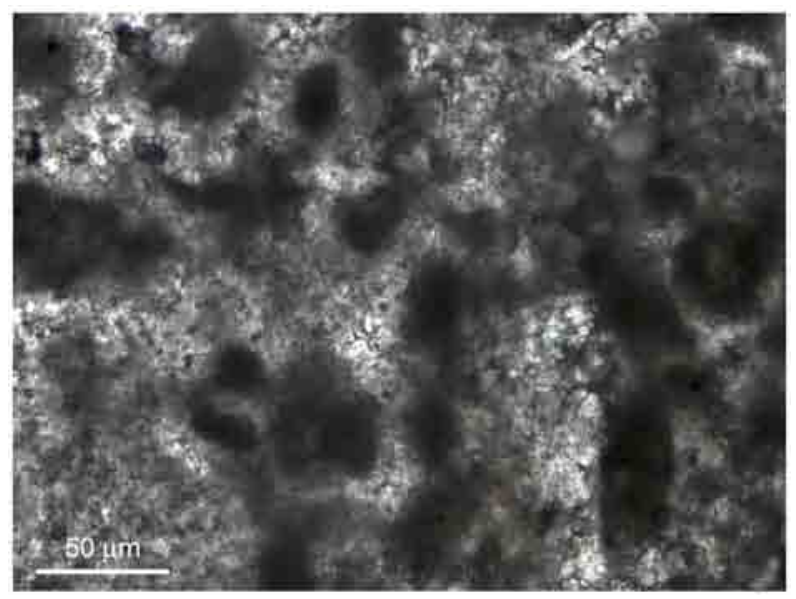

Fig. 1. Photomicrograph of thrombolitic microfacies.

The CdB has coherent REE + Y patterns and shares the essential shale-normalised characteristics of other microbial samples reported in literature for a large geological time span (Webb \& Kamber 2000).

Shale normalized REE $+\mathrm{Y}$ patterns of the $\mathrm{CdB}$ show: (a) enrichment in heavy REE $(\mathrm{NdSN} / \mathrm{YbSN}=0.52, \mathrm{SD}=0.09),(\mathrm{b})$ negative $\mathrm{Ce}$ and positive La anomalies, $(\mathrm{c})$ marine $\mathrm{Y} / \mathrm{Ho}$ ratios $(57.08, \mathrm{SD}=3.07)$, and $(\mathrm{d})$ slightly positive $\mathrm{Gd}$ anomalies. These characteristics suggest that $\mathrm{CdB}$ incorporated REEs in equilibrium with oxygenated seawater and they are in agreement with microbial induced carbonate precipitation.

All these data point to a marine depositional scenario, stressed by episodic freshwater inputs, in which carbonate precipitation was induced by bacterial ammonification of amino-acids in aerobic conditions.

\section{References}

Bellanca, A.; Caruso, A.; Ferruzza, G.; Neri, R.; Rouchy, J. M.; Sprovieri, M. \& Blanc-Valleron, M. M. 2001. Sedimentary record of the transition from marine to hypersaline conditions in the Messinian Tripoli Formation in the marginal areas of the Sicilian Basin. Sedimentary Geology 139: 87-106. 
Decima, A.; McKenzie, J. A. \& Schreiber, B. C. 1988. The origin of "evaporitive" limestones: an example from the Messinian of Sicily (Italy). Journal Sedimentary Petrology 58: 256-272.

Guido, A.; Jacob, J.; Gautret, P.; Laggoun-Defarge, F.; Mastandrea, A. \& Russo, F. 2007. Molecular fossils and other organic markers as palaeoenvironmental indicators of the Messinian CdB Formation: normal versus stressed marine deposition (Rossano Basin, northern Calabria, Italy). Palaeogeography, Palaeoclimatology, Palaeoecology 255: 265-283.

Rouchy, J. M. \& Caruso, A. 2006. The Messinian salinity crisis in the Mediterranean basin: A reassessment of the data and an integrated scenario. Sedimentary Geology 188-189: 35-67.

Webb, G. E \& Kamber, B. S. 2000. Rare earth elements in Holocene reefal microbialites: a shallow seawater proxy. Geochimica Cosmochimica Acta 64: 1557-1565.

\section{The Characterization of Sedimentary Organic Matter in Carbonates with Fourier Transformed-Infrared (FT-IR) Spectroscopy [poster]}

Adelaide Mastandrea, Adriano Guido, Fabio Demasi, Silvestro Antonio Ruffolo \& Franco Russo

\section{Dipartimento di Scienze della Terra, Università della Calabria, Rende (CS), Italy; E-mail: a.mast@unical.it,aguido@unical.it\&f.russo@unical.it}

The organic matter characterization in the carbonate sediments allows the identification of organisms that are or not recognizable or not preserved. Therefore this approach permits to reveal biotic mediation in the carbonate precipitation.

To perform fast analyses on organic matter, able to recognize not only its crude presence but also its geochemical composition and thermal maturity, we tested the Fourier Transformed-InfraRed (FT-IR) spectroscopy on samples already studied and characterized through molecular fossils and other organic markers (Guido et al. 2007). The Authors demonstrated that the Calcare di Base (CdB), cropping out in the Rossano Basin (Northern Calabria, Italy), was deposited via heterotrophic bacterial activity in a marine setting.

FT-IR provides a broad range of chemical functional groups in a variety of physical states and it is complementary to other instrumental methods such as Raman spectroscopy and Gas Chromatography-Mass Spectroscopy (GC/MS). FTIR generally furnishes better sensitivity for minor components than Raman spectroscopy and a comparable capability to classify and identify minerals.

Infrared Spectroscopy using a FT-IR system detects a wide range of organic compounds and gives additional information about the biomineral matrix. The infrared analysis experiment does not target particular molecules but readily detects classes of molecules. Each organic group (i. e. aliphatic $\mathrm{C}-\mathrm{H}$ bonds) is integrated from many compounds at a particular wavelength and this provides high sensitivity for mixtures (Anderson et al. 2005). 
The sensitivity of IR analysis for organic molecules depends on the mineral phase and the granular state. It increases if organics are extracted or thermally desorbed and concentrated. With extraction, FT-IR methods could readily detect parts per billion levels of organic compounds. However, the carbonates that have higher local organic concentrations associated with the microbial activity, such as the clots of peloids in the thrombolites, are readily detected.

In our experiment on the $\mathrm{CdB}$ samples, considering the very low organic matter content measured with Rock-Eval pyrolysis, it has been necessary to concentrate the organic compounds. Powdered dry sediments were ultrasonically extracted with a mixture of dichloromethane/methanol (1:1). Samples were centrifuged, the supernatant was collected and few parts was disposed on the ATR apparatus and dried under nitrogen flow.

The infrared spectra showed bands between 600 and $3000 \mathrm{~cm}^{-1}$ (Fig. 1). They contains stretching aliphatic bands $\left(\mathrm{vCH}_{\text {ali }}\right)$ at 2949,2918 and $2848 \mathrm{~cm}^{-1}$, and deformation bands of methyl $\left(\delta \mathrm{CH}_{3} ; 1365 \mathrm{~cm}^{-1}\right)$ and both methyl and methylene $\left[\delta\left(\mathrm{CH}_{2}+\mathrm{CH}_{3}\right) ; 1458 \mathrm{~cm}^{-1}\right]$ groups. The spectra also display the band assigned to carbonyl and/or carboxyl groups $\left(v \mathrm{C}=\mathrm{O} ; 1740 \mathrm{~cm}^{-1}\right)$. In addition, the band assigned to the skeletal vibration of more than four methylene groups $\left[\gamma\left(\mathrm{CH}_{2}\right)_{4}\right.$; $\left.720 \mathrm{~cm}^{-1}\right]$ has been observed. The $v \mathrm{C}-\mathrm{O}$ vibration appears between 1300 and $1100 \mathrm{~cm}^{-1}$.

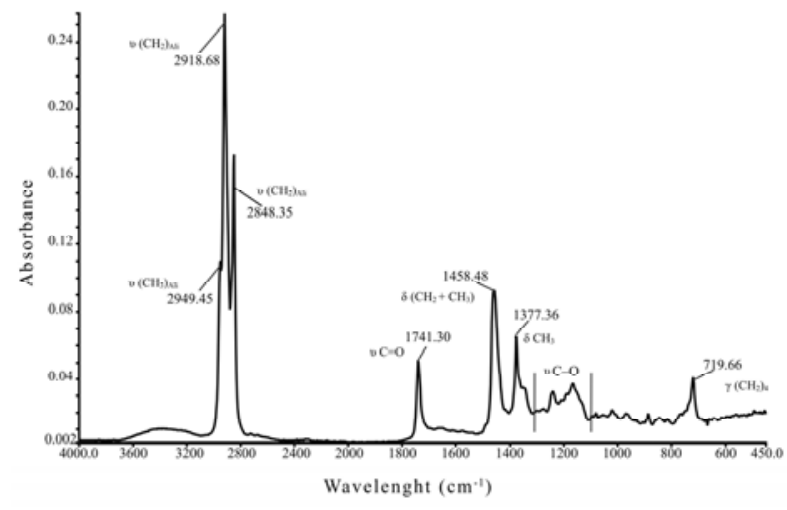

Fig. 1. Infrared spectrum of a representative sample (CB1) of the Calcare di Base.

Some ratios between the peak heights of the FT-IR bands (Borrego et al. 1995) allowed to characterize the kerogen of the $\mathrm{CdB}$. The ratio carbonyl to aliphatic groups $\left(v \mathrm{C}=\mathrm{O} / v \mathrm{CH}_{\text {ali }}\right)$ permitted to distinguish the marine $v s$ continental inputs, whereas chain length $\left(\delta \mathrm{CH}_{2} / \delta \mathrm{CH}_{3}\right)$ and degree of branching $\left[v\left(\mathrm{CH}_{2}\right)_{4} / v \mathrm{CH}_{\text {ali }}\right]$ permitted to evaluate the thermal maturity of the organic matter. 
The data converge to those of the organic geochemical study (Rock-Eval pyrolysis and GC-MS) (Guido et al. 2007) and permit to consider the FT-IR a reliable approach in the characterization of the organic matter preserved in carbonates sediments.

\section{References}

Anderson, M. S.; Andringa, J. M.; Carlson, R. W.; Conrad, P.; Hartford, W.; Shafer, M.; Soto, A. \& Tsapin, A. I. 2005. Fourier transform infrared spectroscopy for Mars science. Review of Scientific Instruments 76: 034101 (1-9).

Borrego, A. G.; Blanco, G. C.; Prado, J. G.; Díaz, C. \& Guillén, M. D. 1995. Study of the bitumenes and pirolizates from some Spanish oil shale by $1 \mathrm{H}$ NMR and FTIR spectroscopy. In: Grimalt, J. O. \& Dorronsoro, C. (eds.): Organic Geochemistry: Developments and Applications to Energy, Climate, Enviromental and Human History 24: 798-800.

Guido, A.; Jacob, J.; Gautret, P.; Laggoun-Defarge, F.; Mastandrea, A. \& Russo, F. 2007. Molecular fossils and other organic markers as palaeoenvironmental indicators of the Messinian CdB Formation: normal versus stressed marine deposition (Rossano Basin, northern Calabria, Italy). Palaeogeography, Palaeoclimatology, Palaeoecology 255: 265-283.

\section{A New Twist on Bioerosion: Helicoidal Ichnofossils in Volcanic Glass and Microbial Life in the Sub-seafloor [talk]}

Nicola McLoughlin ${ }^{1}$, Harald Furnes ${ }^{1}$, Daniel Fliegel ${ }^{1}$, Neil R. Banerjee ${ }^{2} \&$ Hubert Staudigel ${ }^{3}$

${ }^{1}$ Department of Earth Science \& Center for Geobiology, University of Bergen, Bergen, Norway; E-mail: Nicola.Mcloughlin@geo.uib.no, berald.furnes@geo.uib.no@odaniel.fliegel@geo.uib.no

${ }^{2}$ Department of Earth Sciences, University of Western Ontario, London, Ontario, Canada; E-mail: neil.banerjee@gmail.com

${ }^{3}$ Scripps Institution of Oceanography, University of California, La Jolla, CA, US A; E-mail: hstaudigel@ucsd.edu

Microbial activity in volcanic glass creates micron-sized cavities (Thorseth et al. 1992). These bioerosion traces are commonly found in the glassy rims of oceanic pillow lavas and volcanic breccias and can be regarded as ichnofossils (McLoughlin et al. 2008). Morphologically comparable mineralized traces are also found in (meta)-volcanic glasses from ophiolites and Precambrian greenstone belts (Furnes et al. 2007). Several types of evidence including microbiological studies, chemical mapping, isotopic fractionation and morphometrics support a microbial origin for these ichnofossils (Staudigel et al. 2008). Two broad morphological types have previously been recognized and termed "granular" and "tubular" bioalteration textures. A review of material known to date leads us to propose two correspondding ichnogenera and five novel ichnospecies. These are characterized by SEM and optical microscopy and include a granular form; an unornamented tubular form; an 
annulated tubular form; a helicoidal tubular form and a branched form. Of particular interest are complex helical forms investigated by extended depth of focus imaging which has revealed single and double stranded tubular forms with spiraled morphologies.

The ichnotaxonomy proposed here is intended to aid the future development of these bioerosion traces as palaeoenvironmental indicators and tracers of microbial evolution in the deep biosphere.

\title{
References
}

Furnes, H.; Banerjee, N. R.; Staudigel, H., Muehlenbachs, K.; McLoughlin, N.; Wit, M. de \& Van Kranendonk, M. 2007. Comparing petrographic signatures of bioalteration in recent to Mesoarchean pillow lavas: tracing subsurface life in oceanic igneous rocks. Precambrian Research 158: 156-176.

McLoughlin, N.; Furnes, H.; Banerjee, N. R.; Staudigel, H.; Muehlenbachs, K.; Wit, M. de \& Van Kranendonk, M. 2008. Micro-Bioerosion in Volcanic Glass: extending the ichnofossil record to Archean Basaltic Crust. In: Wisshak, M. \& Tapanila, L. (eds.): Current Developments in Bioersion. pp. 371-396; Heidelberg etc. (Springer).

Staudigel, H.; Furnes, H.; McLoughlin, N.; Banerjee, N. R.; Connell, L. B. \& Templeton, A. 2008, in press. 3.5 Billion years of glass bioalteration: Volcanic rocks as a basis for microbial life? Earth Science Reviews.

Thorseth, I. H.; Furnes, H. \& Heldal, M. 1992. The importance of microbiological activity in the alteration of natural basaltic glass. Geochimica et Cosmochimica, Acta 56: 845-850.

\section{Growth of synthetic stromatolites and wrinkle structures in the absence of microbes - implications for the early fossil record [poster]}

\author{
Nicola McLoughlin ${ }^{1}$, Lucy A. Wilson² \& Martin D. Brasier ${ }^{2}$ \\ ${ }^{1}$ Department of Earth Sciences \& Centre for Geobiology, Bergen, Norway; E-mail: \\ Nicola.Mcloughlin@geo.uib.no \\ ${ }^{2}$ Department of Earth Sciences, Parks Road, Oxford, UK; E-mail:palaeolucy@zzircles.com \& \\ martinbrasier@yahoo.co.uk.
}

Stromatolites and wrinkle structures are important biosignatures for tracing microbial evolution on the early earth. While both may be shaped by microbial mat growth, the contribution of abiotic processes in their construction also needs to be established (Grotzinger \& Knoll 1999). Laboratory spray deposition experiments are here described that can generate stromatolites (sensu Semikhatov 1979) and wrinkle structures in the absence of microbes ((McLoughlin et al. 2008). These mini-columnar and sometimes branched stromatolites are produced artificially by the aggregation of a synthetic colloid in a turbulent flow regime. They self-organize at the relatively low particle concentrations found in the outer parts of a spray beam. This contrasts with adjacent stratiform deposits that are produced by high 
rates of colloid deposition and relatively low sediment viscosities found in the centre of a spray beam. These stratiform laminae subsequently become wrinkled during hardening of the colloid. These results support numerical models which together suggest that physicochemical processes are capable of generating laminated sedimentary structures without the direct participation of biology (Grotzinger \& Rothman 1996). Geological environments where comparable abiogenic stromatolites and wrinkle structures may be found are reviewed and include: splash-zone silica sinters, desert varnish crusts and some early Archean cherts formed from silica gel precursors.

\section{References}

Grotzinger, J. P. \& Knoll, A. H. 1999. Stromatolites in Precambrian carbonates; evolutionnary mileposts or environmental dipsticks? Annual Review of Earth and Planetary Science Letters 27: 313-358.

Grotzinger, J. P. \& Rothman, D. H. 1996. An abiotic model for stromatolite morphogenesis. Nature 383: 423-425.

McLoughlin, N.; Wilson, L. A. \& Brasier, M. D. 2008. Growth of synthetic stromatolites and wrinkle structures in the absence of microbes - implications for the early fossil record. Geobiology 6: 95-105.

Semikhatov, M. A.; Gebelein, C. D.; Cloud, P.; Awramik, S. M. \& Benmore, W. C. 1979. Stromatolite morphogenesis: progress and problems. Canadian Journal of Earth Science 19: 992-1015.

\section{Early Precambrian stromatolite assemblages of the Baltic Shield [poster]}

Pavel V. Medvedev \& VladimirV. Makarikhin

Institute of Geology, Karelian Research Centre, Russian Academy of Science, Petrozavodsk, Russia; E-mail:pmedved@,krc.karelia.ruevmakar@krc.karelia.ru

Stromatolites had their maximum distribution on the Baltic Shield during Jatulian time (Palaeoproterozoic). Here they were abundant both quantitatively and taxonomically (Melezhik et al. 1997). In Russian Karelia (eastern part of the shield) stromatolites are occurring in terrigenous-carbonate sequence of the Upper Jatulian Onegian Formation which has a Pb-Pb age $2090 \pm 70 \mathrm{Ma}$ (whole rock determination) (Ovchinnikova et al. 2007). The $800 \mathrm{~m}$ thick succession of Onegian Formation mainly consists of reddish ${ }^{13} \mathrm{C}$-enriched dolostones with mud-cracked siltstone and ripple-marked quartzite interbeds. The sediments show numerous lithological features of an evaporate environment (Melezhik et al. 1999). In the sequence of the Onegian Formation stromatolites form 5 successive assemblages following each other. Some of these assemblages are traced laterally across a long distance - a few hundred kilometers on Karelian territory. It has been a basis for establishing biostratigraphic units in regional Early Proterozoic succession - beds with Lithophyta (Makarikhin 1992). With help of these units both subdividing and correlation of separate parts of the carbonate sequence are possible at least within 
Karelian region of the Baltic Shield. There are stromatolite localities to the north of Karelia - in the Kola Peninsula and in the Western Baltic Shield - Finland and Sweden (Medvedev et al. 2006; Melezhik et al. 1997), which mark the same Late Jatulian time level. Besides, some Palaeoproterozoic stromatolites from approximately the same time interval of the Canadian Shield are similar to those from the Baltic Shield (Medvedev et al. 2006). These coeval stromatolite-bearing Palaeoproterozoic successions in time interval 2.2-2.0 Ga are characterized by carbonates with unusual high positive values for $\delta^{13} \mathrm{C}_{\text {carb }}=8.0-9.0 \%$ PDB on average (Karhu \& Holland 1996). Thus after detailed investigations including description and comparison of the stromatolites, subdivision and correlation of these terrigeniouscarbonate sequences will be possible not only on the Baltic Shield but between Baltic and Canadian Shields too - both regional and intercontinental correlations will be possible.

Acknowledgements: The research was supported by Program 18 of Russian Academy of Science "Biosphere Origin and Evolution".

\section{References}

Karhu, J. A. \& Holland, H. D. 1996. Carbon isotopes and the rise of atmospheric oxygen. Geology 24 (10): 867-870.

Makarikhin, V. V. 1992. Lower Precambrian Stromatolite Associations of Karelia. In: Schidlowski, M. et al. (eds.): Early Organic Evolution. pp. 463-467; Berlin etc. (Springer).

Medvedev, P.; Bekker, A.; Karhu, J.; Kortelainen, N. 2005. Testing the biostratigraphic potential of the early Paleoproterozoic microdigitate stromatolites. Revista Española de Micropaleontologia 37 (1): 41-56.

Medvedev, P.; Karhu, J.A. \& Kortelainen, N. 2006. Comparative lithology, geochemistry and stromatolites of the Paleoproterozoic Perapohja Schist Belt in Finland and Soanlachti Formation in Russian Karelia. In: 27th Nordic Geological Winter Meeting. Abstract Volume. Bulletin of the Geological Society of Finland Special Issue 1: p. 101.

Melezhik, V. A.; Fallik, A. E.; Makarikhin, V. V. \& Lyubtsov, V. V. 1997. Links between Palaeoproterozoic palaeogeography and rise and decline of stromatolites: Fennoscandian Shield. Precambrian Research 82: 311-348.

Melezhik, V. A.; Fallik, A. E.; Medvedev, P. V.; Makarikhin, V. V. 1999. Extreme ${ }^{13} C_{\text {carb }}$ enrichment in ca. 2.0 Ga magnesite-stromatolite-dolomite-"red beds" association in a global context: a case for the world-wide signal enhanced by a local environment. Earth Science Reviews 48: 71-120.

Ovchinnikova, G. V.; Kuznetsov, A. B.; Melezhik, V. A.; Gorokhov, I. M.; Vasil'eva, I. M. \& Gorokhovskii, B. M. 2007. Pb-Pb age of Jatulian carbonate rocks: The Tulomozero Formation of southeast Karelia. Stratigraphy and Geological Correlation 15 (4): 20-33. 


\title{
Stromatolites in Shark Bay, Western Australia: Interglacial and sub- tidal origins [poster]
}

\author{
Dieter Meischner \\ Geowissenschaftliches Zentrum, Abt. Sedimentologie / Umweltgeologie, Universität Göttingen, Göttingen, \\ Germany; E-mail:dmeisch@gwdg.de
}

Hamelin Pool, Shark Bay, Western Australia, is famous for its extended fields of stromatolites in the intertidal zone, and for the Hamelin Coquina: beach ridges built up almost exclusively of the small bivalve Fragum erugatum. The stromatolites extend below present low tide.

By far the greater part of the spectacular stromatolites in the intertidal zone of Hamelin Pool is dead. Living growth is restricted to pustular overgrowth of Entophysalis major on dead columnar and club-shaped stromatolites and as partly ridged mats in the higher intertidal, and to smooth mats of Microcoleus cbthonoplastes in the lower intertidal and shallow subtidal zones. Prolific stromatolite growth, however, occurs in the sublittoral zone, where colloform mats form columnar and ridged bodies of shape and individual dimensions similar to the dead forms in the intertidal.

Most of the stromatolite structure as now exposed intertidally originated during the last (IS 5.5, Sangamon- or Eem-) interglacial, and in a sub-littoral setting. Sea level rose to 1-2 $\mathrm{m}$ above present datum, and an onlapping series of calcareous sand and rubble with diverse marine shelly fauna and corals was deposited along the shores of Hamelin Pool, known locally as Bibra Limestone. The limestone was topped by flat domal and tepee-like algal mats. During sea-level highstand domal and club-shaped stromatolites grew subtidally. They were partly destroyed on incipient regression, and their ruins infilled with seaward-dipping, down-lapping siliceous sands, now lithified.

Likewise, the Hamelin Coquina is for its greater part of interglacial origin. It extends all around Hamelin Pool to a maximum height of $10 \mathrm{~m}$, and width of $1 \mathrm{~km}$. The Pleistocene coquina is thoroughly re-cristallized, blocky calcite has completely replaced the originally aragonitic shell mineralogy.

The Pleistocene cycle of sea-level rise, highstand and retreat is principally repeated in the Holocene at a 1-2 m lower level. The quantitative contribution of Holocene stromatolites and coquina, however, has remained minimal due to the short time since the recent inundation of Hamelin Pool. 


\section{Systematic comparison of different molecular tools for holistic characterization of a TCE-contaminated subsurface system [poster]}

Daniela B. Meisinger ${ }^{1}$, Marko Pavlekovic ${ }^{1}$, Kai-Uwe Totsche ${ }^{2}$, Viviane Radl ${ }^{3}$, Michael Schloter ${ }^{3}$, Michael Schmid ${ }^{4}$, Wolfgang Liebl ${ }^{1}$, Kirsti M. Ritalahti ${ }^{5}$, Carmen Lebrón $^{6}$, Frank E. Loeffler ${ }^{5}$, Natuschka M. Lee ${ }^{1}$

${ }^{1}$ Technical University of Munich, Microbiology, Freising, Germany; E-mail:

daniela.meisinger@msecol.net,marko.pavlekovi@@msecol.net, liebl@wzw.tum.de,leen@mikro.biologie.tumuenchen.de

${ }^{2}$ Friedrich Schiller University of Jena, Institute of Geosciences, Jena, Germany; E-mail: kai.totsche@unijena.de

${ }^{3}$ Helmboltz Zentrum München, Soil Ecology, Neuherberg, Germany; E-mail: viviane.radl@helmboltzmuenchen.de \& michael.schloter@helmboltz-muenchen.de

${ }^{4}$ Helmboltz Zentrum München, Plant Microbe Interactions, Neuherberg, Germany; E-mail: michael.schmid@helmholtz-muenchen.de

${ }^{5}$ Georgia Institute of Technology, Environmental microbiology and engineering, Atlanta, US A; E-mail: krita@ce.gatech.edußofrank.loeffler@ce.gatech.edu

${ }^{6}$ NFESC, Port Hueneme, USA; E-mail: carmen.lebron@navy.mil

Chloroorganic compounds such as chlorinated ethenes are widespread environmental pollutants in the subsurface. These compounds can be detoxified by reductively dechlorinating bacteria. However, depending on species, different degradation reactions may occur, some of them yielding more toxic products such as VC. Thus, for a successful bioremediation, detailed knowledge about the composition of dechlorinating assemblages is required. Here, we describe the difficulties to characterize the unknown, native microbial community associated with a TCE and BTEX contaminated aquifer in Southern Germany where significant in situ reductive dechlorination to ethene occurs. We applied a comprehensive approach encompassing ten different tools for a systematic comparison: clone libraries of $16 \mathrm{~S}$ rRNA, 18S rRNA and rpoB genes; cultivation on TCE and lactate based media; screening of all known dechlorinators by DGGE, nested PCR, and fluorescence in situ hybridization (FISH), qPCR for quantification of detected dechlorinating bacteria targeting $16 \mathrm{~S}$ rRNA and different reductive dehalogenase genes. We observed significant discrepancies between the different tools applied, which indicates how important it is to combine several tools for a holistic comprehension of the true biodiversity in a contaminated site. Interestingly, we also observed that only a minor part of all microorganisms retrieved were affiliated to previously described taxa, which shows that a significant unexplored diversity in chloroorganic contamined sites still exist. Screening of $80016 \mathrm{~S}$ rRNA gene clones yielded 10 different phyla, encompassing mostly not-yet-cultured representatives affiliated with e. g. the Chloroflexi, Deltaproteobacteria, Firmicutes, and different novel candidate groups. In addition, additional 115 isolates were retrieved, which encompassed five different phyla, dominated in particular by Actinobacteria and Bacteroidetes. Interes- 
tingly, none of these isolates were represented in the 16S rRNA gene clone library. Screening of $14018 \mathrm{~S}$ rRNA clones yielded 11 phyla, encompassing mostly not-yetcultured fungal representatives with unknown function. The only known dechlorinator consistently found with most of the applied tools was Geobacter spp. Nonquantitative PCR based detection using specific primers against all known dechlorinating bacteria were negative or yielded false-positive results (in particular when applying genus specific primers for Desulfitobacterium and Dehalococcoides). Interestingly, quantitative PCR efforts revealed that Geobacter spp. as well as Debalococcoides spp occurred at ratuher low cell titers (Geobacter spp. $2 \%$ of total Bacteria, Dehalococcoides spp. $<0,1 \%$ of total Bacteria counts in 1 Liter groundwater). These low numbers suggest that the observed in situ dechlorination reactions are likely catalyzed by other, not yet identified bacteria. It is interesting to note that qPCR was the only tool, out of all other tools applied in this study, that could detect Dehalococcoides spp. This supports the current hypothesis that qPCR has the lowest detection limit of all known present tools. We are currently in the process of applying an RDase microarray to screen for the diversity of RDase genes on this site. With this we hope to compile the results from the other tools applied in this study with the RDase microarray results to map potentially novel candidates for novel dechlorinating species on this field site.

\section{Diversity of cyanobacteria and other microalgae in two stromatolite- forming freshwater creeks [talk]}

Kathrin I. Mohr, Nicole Brinkmann, Jessica Ramm \& Thomas Friedl

Experimental Phycology and Culture Collection of Algae (SAG), University of Göttingen, Göttingen, Germany; E-mail:kmohr1@gwdg.de,nbrinkmann@gwdg.de,jramm@gwdg.de_tfriedl@unigoettingen.de

This still ongoing project (DFG FR905/13-2), within the DFG research unit FOR 571 "Geobiology of Organo- and Biofilms", aims at assessing the algal/cyanobacterial diversity associated with calcium carbonate precipitation in two hydrochemically different freshwater creeks in order to reveal key-player organisms that may significantly contribute to the biogenic formation of stromatolites. In these creeks, the rocks were covered with thick layered calcified biofilms. Microscopically, they were dominated by cyanobacteria, particularly in summer, and diatoms, which were more dominant in winter. Diversity of cyanobacteria and diatoms was much higher than expected by microscopic examination. Photosynthesis in general was found to have a significant impact on the carbonate equilibrium within the microenvironment of such biofilms. To analyze this and similar effects on the stromatolite forming processes the diversities of cyanobacteria and diatoms were investigated here. 
Mainly molecular methods were applied to avoid biases from culture approaches, but it was also attempted to isolate key-player algae into poor culture. Molecular signatures will also allow to unambiguously revealing the spatial distribution of key player phylotypes within the biofilms using FISH hybridisation. Total DNA from biofilms covering rocks of different sample sites was extracted and SSU rDNAs were amplified, cloned and sequenced. For 10 sampling sites cyanobacterial and for 13 sampling sites diatom clone libraries were established and a large number of clones per site were sequenced. The studied Westerhöfer Bach (westerly Harzforeland, Germany) has its source in shell-limestone karst and has relatively high $\mathrm{Mg}^{2+}$ and $\mathrm{SO}_{4}{ }^{2-}$ concentrations, whereas the Deinschwanger Bach (western rim of the Franconian Alb, Germany) is relatively poor in these ions. Therefore our main focus was on these two groups.

Although both creeks harboured about the same amount of cyanobacteria and diatom diversities, the algal communities of both creeks were different, which may reflect the hydrochemical differences between both creeks. A total of 30 phylotypes of cyanobacteria was detected in both creeks together. Twelve phylotypes were recovered at least from two different sites and, therefore, they were considered as key-players. The biofilms were dominated by the polyphyletic filamenttous Leptolyngbya-, Plectonema-, and Phormidium-like cyanobacteria and several phylotypes representing Chamaesiphon. Many recovered phylotypes could not be identified by the sequence comparisons, but their closest relatives were uncultured cyanobacteria from Antarctica.

The diatom phylotypes were distributed on 24 lineages and clades within a large monophyletic clade representing the raphid pennate diatoms. The monophyletic genera Navicula, Achnanthidium, Amphora, Fistulifera, Gomphonema and Surirella were recovered with several phylotypes (species) each. In addition, also the araphid pennate diatoms, Diatoma, Staurosira and Ulnaria, were found. The diversity of diatoms detected in both creeks was slightly higher than that of the cyanobacteria, i. e. a total of 34 distinct diatom phylotypes was retrieved from cloning/sequencing and the culture approach. A total of 13 key player diatoms were detected at more than three sites, while 11 other phylotypes were found only twice or three times.

In addition to the diatoms an unexpected diversity (30 phylotypes) of other eukaryotic microalgae was found using a culture approach, i. e. Green Algae (Chlorophyceae, Trebouxiophyceae, Ulvophyceae and Klebsormidiophyceae), Xanthophyceae and Eustigmatophyceae. The spring sites of both creeks were the only sites that were not calcified. They harboured completely different cyanobacteria phylotypes, i. e. those that were not found at any calcified site. Diatom diversity was dramatically reduced at the non-calcified sites while the xanthophyte Heterococcus was dominant there. 


\section{Microbial contribution to lamina formation in an aragonite travertine [talk]}

Tomoyo Okumura ${ }^{1}$, Fumito Shiraishi ${ }^{1}$, Takeshi Naganuma $^{2}$, Kise Yukimura ${ }^{2}$, Chiduru Takashima ${ }^{3}$, Shin Nishida ${ }^{3}$, Hiroko Koike ${ }^{3} \&$ Akihiro Kano $^{3}$

${ }^{1}$ Department of Earth and Planetary Systems Science, Graduate School of Science, Hiroshima University, Higashi-biroshima,Japan; E-mail:oktomy888@hiroshima-u.ac.jp@ sshirai@biroshima-u.ac.jp

${ }^{2}$ Department of Enviromental Dynamics and Management, Hiroshima University, Higashi-biroshima, Japan;E-mail:takn@biroshima-u.ac.jp@ kise-yukimura@birosbima-u.ac.jp

${ }^{3}$ Division of Evolution of Earth Environment, Graduate School of Social and Cultural Studies, Kyushu University, Fuknoka, Japan; E-mail: ctakasbima@scs.kyusbu-u.ac.jp, sbin.nsd@niffy.com, koikegss@mbox.nc.kyusbu-u.ac.jpdekano@scs.kyushu-u.ac.jp

Travertines are carbonate (calcite and aragonite) precipitates in hot-spring water containing a sufficient amount of $\mathrm{Ca}$ and $\mathrm{CO}_{2}$ and often exhibit sub-mm order lamination that resemble to the textures seen in ancient stromatolites. For calcite travertines, the laminations indicate daily banding that formed by temporal trapping of detrital particle on cyanobacterial biofilm (Takashima \& Kano in press). Here, we study an aragonite travertine at Nagayu hot spring, Ohita Prefecture (SW Japan), which shows sub-mm order lamination N-layer and L-layer. Observation of a series of samples clearly confirm that the lamination is daily; $\mathrm{N}$-layer consisting of long needle crystals was formed in night time and L-layer having $\mu \mathrm{m}$-scale layering was developed in daytime. The travertine also shows vertical crack of $\sim 100 \mu \mathrm{m}$ wide in which filamentous cyanobacteria occure. As there was no clear daily pattern in physicochemical conditions of water except for sun light, the lamination was not formed by inorganic process but likely by microbial photosynthesis. Imprints of the bacterial activity ware recognized in L-layers, such as EPS stained by Toluidine Blue O, beta-proteobacteria by FISH (Fluorescence in situ hybriddization). Gene analysis indicate that the beta-proteobacteria are dominant in the travertine and show the closest affinity to Hydrogenophaga that is a chemolithoautotroph oxidizing $\mathrm{H}_{2}$ as an energy source, or a heterotroph oxidizing organic compounds. The optimal conditions for this genus are $\sim 35$ degree and near-natural $\mathrm{pH}$ that fit to the Nagayu hot spring. Cyanobacteria ware only minor recognized in gene analysis.

The results mentioned above conduct the microbial processes forming lamination in the travertine; growth of Hydrogenophaga in the daytime layer indicates that the bacteria thrive on EPS or $\mathrm{H} 2$ generation from cyanobacterial photosynthesis. Development of the bacterial film disturbed crystal growth of needle aragonite and resulted in the $\mu \mathrm{m}$-scale layering of the L-layers.

Size and morphology of the Nagayu aragonite travertine closely resemble to those of 'ministromatolite' that commonly occur in the upper Archean to Proteozoic. If we assume that these stromatolites and travertines were formed same process, we 
can specify that the banded structure of these stromatolites were daily and the growth rate was extremely high.

\section{References}

Takashima, C. \& Kano, A. in press. Microbial processes forming daily lamination in a stromatolitic travertine. Sedimentary Geology.

\section{Aggregation Phenomena in Cyanobacterial Analogues of Ancient Stromatolites [talk]}

Alexander Petroff, Min Sub Sim, Biqing Liang, Daniel Rothman \& Tanja Bosak

Department of Earth Atmospheric and Planetary Science, Massachusetts Institute of Technology. Cambridge, MA,USA; E-mail:petroffa@mit.edu

If one is to understand and time the evolution of such fundamental processes as photosynthesis, it is imperative to recognize and interpret microbial fossils. This goal is challenging as many of the oldest putative fossils are only identified as biotic by a distinctive morphology. To this end, we examine the forces that shape modern, cone-forming cyanobacterial mats that are thought to grow in a manner similar to ancient structures called conical stromatolites. Here we show that the initial stages in the growth of a mat are shaped primarily by the diffusion of oxygen over macroscopic distances.

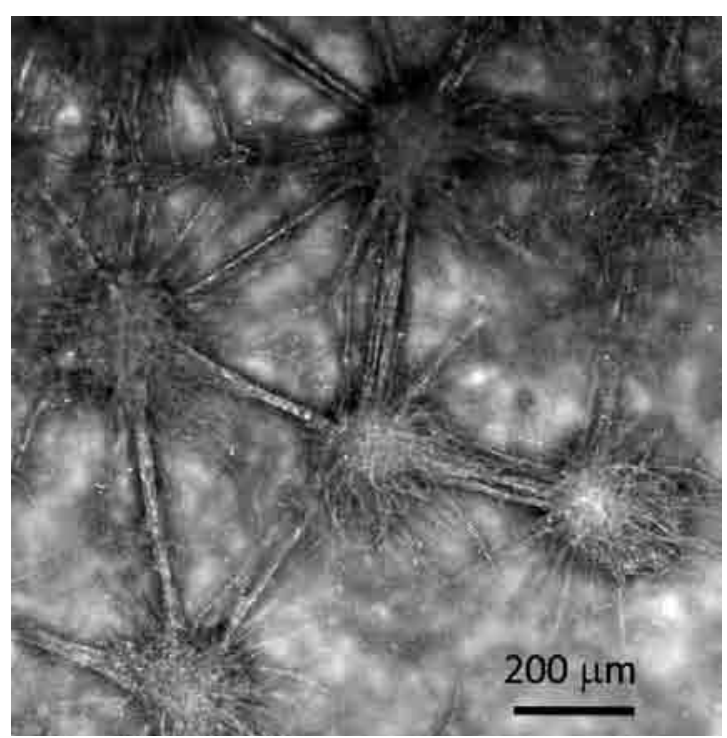

Fig. 1. Clumps of filamentous cyanobacteria forming a roughly hexagonal lattice (top view, chlorophyll autofluorescence). Both the formation of these clumps, which eventually grow into centimeter-scale cones, and their arrangement is set by the diffusion of oxygen. 
We observe that although bacteria aggregate into clumps when oxygen is present, these structures quickly dissolve in anoxic conditions. We therefore conclude that the diffusion of oxygen produced during photosynthesis leads bacteria to form the clumps which eventually grow into cones. Furthermore, we find that these aggregates are often arranged into a centimeter-scale, hexagonal lattice (Figure 1). We show that the lattice spacing is also set by the diffusion of oxygen. We therefore conclude that the diffusion of oxygen, produced by photosynthesis, plays an important role in both the formation of incipient cones and their arrangement on the mat. The importance of an interaction on the scale of the aggregate suggests that many current models of stromatolite morphogenesis, which rely exclusively on bacterium-scale processes, are not applicable to the early stages of growth. Given that the aggregation of bacteria in modern conical microbiolites is driven by the diffusion of a metabolic waste product, we suspect that similar processes may shaped some of Earth's earliest fossils.

\title{
Siliciclastic biolaminites: occurrence and associated structures in modern and ancient peritidal systems [poster]
}

\author{
Hubertus Porada ${ }^{1} \&$ El Hafid Bouougri ${ }^{2}$ \\ ${ }^{1}$ Geowissenschaftliches Zentrum Universität Göttingen, Göttingen, Germany; E-mail: hporada@gwdg.de \\ ${ }^{2}$ Department of Geology, Faculty of Sciences Semlalia, Cadi Ayyad University, Marrakech, Morocco; \\ E-mail:bouougri@ucam.ac.ma
}

Described are thinly laminated siliciclastic sedimentary deposits consisting of alternating, mm-scale, stratiform layers of detrital sediment and microbial mats or relict indication of their former presence. Accretion of the sediments resulted from the interplay of epibenthic biomass production in microbial mats, metabolic processes therein, and sedimentation. Three examples are presented:

(1) Bhar Alouane, modern lagoon and tidal flats, Mediterranean coast of southern Tunisia: The lagoon, connected with the large Sabkha El Melah over a small inlet, is bordered by sand bars separating low-gradient tidal flats from the lagoon. The sand bars are intersected by narrow tidal creeks, through which adjacent areas are inundated at high tides. The regularly flooded areas are characterized by well-developed mats of dominant filamentous cyanobacteria and associated coccoid species. Occasionally, overflowing creek waters load fine-grained, sandy to silty sediment on the mats; thin siliciclastic sediment layers overlying mats may also originate from eolian action. Microbes recolonising the new sediment surface form vertically extended biolaminated deposits (Gerdes et al. 2008), here referred to as 'siliciclastic biolaminites'. The most common structures of mats overlying thick successions biolaminites are $\mathrm{dm}$-scale networks of polygonal cracks with upturned and over- 
grown margins. These usually exhibit irregular patterns resulting from the interplay of progressive upturning and continuous mat growth and overgrowth. Sections across crack margins show different stages varying from incipient upturned margins or simple upturned/overgrown margins to complex patterns resulting from repeated shrinkage, upturning and concomitant overgrowth.

(2) Namibia; Neoproterozoic Vingerbreek Member, Schwarzrand Subgroup, Nama Group: In the lower part of the Vingerbreek Member on farm Haruchas, a more than $20 \mathrm{~m}$ thick succession of siliciclastic biolaminites with intercalated sandstone beds and heterolithic siltstone/mudstone units is preserved (Bouougri \& Porada 2007). Sedimentary features indicate deposition in a low-energy, shallow, intertidal position behind a protecting sand barrier. The biolaminites occur as $\mathrm{m}$-scale units and consist of thinly interlaminated layers of siltstone and dark to black material of variable thickness and proportions. The silty laminae frequently exhibit small interference and oscillation ripples with sharp crests. The rippled surfaces are commonly draped by a dark and continuous film of mudstone. Evidence of the participation of mats that once colonized the sedimentary surfaces and contributed to the accretion of thick stacked layers of siliciclastic biolaminites include mat-related structures like 'elephant skin' (reticulate growth pattern), Kinneyia-type wrinkle structures, spindle-shaped and lenticular shrinkage cracks, subcircular cracks with upturned and 'curled' margins, and sand clasts. Most diagnostic are networks of upturned to overturned polygonal crack margins which are overlain by continuous biolaminated deposits. In thin section, the biolaminites consist of packages, 05$1.5 \mathrm{~mm}$ thick, of 5-10 alternating light and dark layers, separated by mm-scale light layers of silt/sand sized sediment. The dark layers, made up mainly of sericite, Feoxides and scarse relics of carbonaceous material, are considered to represent former microbial mats.

(3) Anti-Atlas belt, Morocco; Neoproterozoic Tiæi n-Taghatine Group: At two stratigraphic levels, siliciclastic biolaminites are extensively preserved within a heterolithic facies association deposited in the intertidal to supratidal zones of a broadly peritidal coastal environment that experienced episodic emergence, intermittent fluvial sheet-floods and high-energy storm-tide events. The biolaminites consist of thinly laminated sediments with $\mathrm{mm}$-scale alternations of siltstone and sericitic argillite, and usually include some thicker, $\mathrm{cm}$-scale quartzite beds and lenses. The microstructure comprises an alternation of silt-sized quartz laminae and laminated sericitic argillite. The latter includes isolated, 'floating' quartz grains and lenses and subrounded aggregates of 'coated' grains. The first occurrence of biolaminites consists of $\mathrm{cm}$-thick interbeds of laminated organo-sedimentary layers draping $\mathrm{cm}$ - to $\mathrm{dm}$ thick sandstone beds. Associated structures are shrinkage cracks of variable shape and size. The second occurrence is made up of $\mathrm{dm}$ - to meter thick laterally continuous beds that exhibit two types of morphologies: (i) planar biolaminites characterized by a flat to wavy-crinkly laminated structure; (ii) domal biolaminites characterized by domes, commonly subcircular in shape and $10-30 \mathrm{~cm}$ across. The planar biolaminites exhibit shrinkage cracks ranging from isolated, lenticular and spindle- 
shaped types to networks of polygonal cracks. Within a package of biolaminite, lenticular shrinkage cracks may occur at several levels indicating multiple repetitions of mat growth, shrinkage and cracking. A specific type of shrinkage structure is characterized by upturned and overgrown crack margins, ranging from simple to complex patterns. The structures imply continuous and repeated processes of shrinkage, upturning and overgrowth until the margin-structure is sealed by new and continuous mat layers.

Remarks on the terms 'biolaminite' and 'siliciclastic biolaminite': The term 'biolaminite' was introduced by Gerdes \& Krumbein (1987) to describe a specific type of 'biolaminated deposits' within a range of 'stromatolitic facies types' observed in Gavish Sabkha. In this definition, siliciclastic biolaminites consist of quartz sand and interlayered laminae originating from microbial mats. A carbonate component, typical of the other stromatolitic facies types, is missing in these deposits. 'Siliciclastic biolaminites' result from a process including periods of non-deposition in which organisms produce and establish mat layers on a sediment surface, and periods of sedimentation in which the mat is covered by a thin layer of fine-grained sediment through which motile bacteria can move upwards to establish a new mat atop. Thus, 'siliciclastic biolaminites' are microbialites (Burne \& Moore 1987), in the broadest sense, and stromatolites applying Riding's (1991) definition as "laminated benthic microbial deposits" (in practice mainly applied to laminated carbonate rocks). They may even be grouped as "agglutinated stromatolites", as trapping or agglutination of sediment grains by the participating mat plays a role. In two fundamental features and their combined occurrence, however, 'siliciclastic biolaminites' deviate from this definition: (1) the systematic, mm-range alternation of microbial mat layers and siliciclastic, detrital sediment layers introduced into the system by physical forces, and (2) the lack of any carbonate cementation.

\section{References}

Bouougri, E. H. \& Porada, H. 2007. Siliciclastic biolaminites indicative of widespread microbial mats in the Neoproterozoic Nama Group of Namibia. Journal of African Earth Sciences 48: 38-48.

Burne, R. V. \& Moore, L. S. 1987. Microbialites: organosedimentary deposits of benthic microbial communities. Palaios 2: 241-254.

Gerdes, G. \& Krumbein, W. E. 1987. Biolaminated Deposits. In: Bhattacharya, G. M.; Friedmann, G. M.; Neugebauer, H. J. \& Seilacher, A. (eds.): Lecture Notes in Earth Sciences 9: 1-183.

Gerdes, G.; Porada, H. \& Bouougri, E. H. 2008. Bio-sedimentary structures evolving from the interaction of microbial mats, burrowing beetles and the physical environment of Tunisian coastal sabkhas. Senckenbergiana maritima 38: 45-58.

Riding, R. 1991. Classification of microbial carbonates. In: Riding, R. (ed.): Calcareous Algae and Stromatolites. pp. 21-51; Berlin etc. (Springer). 


\section{Microbial colonization of artificial composite mineral substrates [poster] \\ Marie Ragon, David Moreira \& Purificación López-García \\ Unité d'Ecologie, Systématique \& Evolution, CNRS UMR 8079, Université Paris-Sud, Orsay, France; E-mail:marie.ragon@u-psud.fr, david.moreira@u-psud.frosuri.lopez@u-psud.fr}

The intimate biogeochemical mechanism of microbialite formation is still poorly understood. One major unsolved question is whether microorganisms induce carbonate precipitation (actively or passively) or whether, alternatively, carbonate precipitation occurs abiotically and microbial colonization takes place along with it. In order to set a reference model for the latter possibility, we focus our interest on the colonization process of virgin / sterile composite mineral supports exposed to the open air in natural environments. The substrates analyzed were placed at different geographical locations in West and central France and were exposed to natural conditions for periods between 2 and 7 years. We then characterized by molecular methods the microbial composition associated with the exposed substrates by amplifying, cloning and sequencing genes encoding the $16 \mathrm{~S}$ and $18 \mathrm{~S}$ rRNA for different microbial taxa. Specific primers for bacteria, archaea and eukaryotes were used. For bacteria, primers specific for cyanobacteria were also used. No sequence belonging to the Archaea was detected; the communities were mainly dominated by bacteria and eukaryotes. We found a significant diversity within bacteria, and some heterogeneity between samples. Alphaproteobacteria, Actinobacteria and Deinococcales and, to a lesser extent, Bacteroidetes, were found to be the dominant groups in all the samples tested. Among the cyanobacteria, members of the orders Oscillatoriales, Chroococcales, Pleurocapsales and Nostococales, also well represented in some stromatolites, were most often present. In addition, we also observed many chloroplast genes belonging to green and stramenopile algae. This is in agreement with the identification based on 18S rRNA genes of green algae (Chlorophyta and Streptophyta) and stramenopile algae (Xantophyta) in addition to fungi.

\section{Methane derived microbialites at cold seeps from the Black Sea [talk]}

Joachim Reitner ${ }^{1}$, Nadine Schäfer ${ }^{1}$, Christina Heller ${ }^{1}$, Michael Hoppert ${ }^{2}$, Christoph Wrede ${ }^{2} \&$ Volker Thiel $^{1}$

${ }^{1}$ Department of Geobiology, University of Göttingen, Germany; E-mail:jreitne@gwdg.de, nschaef1@gwdg.de, cheller@gwdg.de \& vthiel@gwdg.de

2Institute of Microbiology and Genetics, University of Göttingen, Germany; E-mail:mhopper@gwdg.de \& cwrede@gwdg.de 
In the euxinic waters of the NW' Black Sea shelf early lithified sediments, sedimentary concretions (Reitner et al. 2005a), and tower-like carbonate build-ups up to several meters in height (Reitner et al. 2005b) grow at sites of cold methane seepage. An integrated approach using fluorescence-, cathodoluminescence, electron microscopy, fluorescence in situ hybridization, lipid biomarkers, stable isotopes $\left(\delta^{13} \mathrm{C}\right)$, electron microprobe \& La-ICP-MS analyses, and petrography revealed insight into the anatomy of methane-derived carbonates. The tower structures are part of an unique microbial ecosystem that shows a considerable biodiversity and a remarkable degree of organization. The accretion of the tower-like build-ups is promoted by the growth of $\mathrm{cm}$-sized, methane-filled spheres constructed by calcifying microbial mats. Progressive mineralization of these spheres involves the early precipitation of ${ }^{13} \mathrm{C}$-depleted, strongly luminescent high-Mg-calcite rich in iron sulphides, and closely interfingered aragonite phases that finally create the stable (mega-) thrombolithic fabric of the towers. Within the microbial mats, microorganisms occur in distinctive spatial arrangements. Major players among the microbial consortia are the archaeal groups ANME-1 and ANME-2, Crenarchaeota and sulphate-reducing bacteria of the Desulfosarcina/Desulfococcus group (Blumenberg et al. 2004). The latter exhibit intracellular storage inclusions and greigite $\left(\mathrm{Fe}_{3} \mathrm{~S}_{4}\right)$ magnetosomes indicating that iron cycling is involved in the metabolism of the microbial population. The key process leading to the formation of these carbonates is the anaerobic oxidation of methane (AOM) via a coupling of reverse methanogenesis (Heller et al. 2008, Shima \& Thauer 2005) and sulphate reduction.

\section{References}

Reitner, J.; Peckmann, J.; Blumenberg, M.; Michaelis, W.; Reimer, A. \& Thiel, V. 2005a. Anatomy of methane-derived carbonates and associated microbial communities in Black Sea sediments. Palaeogeography, Palaeoclimatology, Palaeoecology 227: 18-30.

Reitner, J.; Peckmann, J.; Reimer, A.; Schumann, G. \& Thiel, V. 2005b. Methane-derived carbonate build-ups and associated microbial communities at cold seeps on the lower Crimean shelf (Black Sea). Facies 51: 66-79.

Blumenberg, M.; Seifert, R.; Reitner, J.; Pape, T. \& Michaelis, W. 2004. Membrane lipid patterns typify distinct anaerobic methanotrophic consortia. PNAS 101 (30): 11111-11116.

Heller, C.; Hoppert, M. \& Reitner, J. 2008. Immunological localization of Coenzyme M Reductase in anaerobic methane-oxidizing archaea of ANME1 and ANM2 type. Geomicrobiology Journal 25: 1-8.

Shima, S. \& Thauer, R. K. 2005. Methyl-coenzyme M reductase and the anaerobic oxidation of methane in methanotrophic Archaea. Current Opinion in Microbiology 8: 643-648. 


\title{
Microbial communities from the Fe-Mn banded crusts and macro- oncoids related to hardgrounds of the Eastern External Subbetic (SE Spain) [poster]
}

\author{
Matías Reolid \& Luís M. Nieto \\ Departamento de Geología. Universidad de Jaén, Jaén, Spain; E-mail:mreolid@ujaen.es \& \\ Imnieto@ujaen.es
}

Ferromanganesiferous macro-oncoids are characteristic in the External Subbetic (Betic Cordillera, SE Spain) in relation to a major unconformity that includes the Middle Bathonian-Middle Oxfordian gap. During the Mid-Late Jurassic boundary, the Southern Iberian Palaeomargin showed mixed features of a transform and a passive margin where the External Subbetic was made up by a lot of pelagic swells. The unconformity is represented in this sector by neptunian dykes, firmgrounds, hardgrounds and $\mathrm{Fe}-\mathrm{Mn}$ banded crusts and macro-oncoids. Analyses of these FeMn microbialites with scanning electron microscopy using secondary electrons allow us to recognise fossil microbes.

The Fe-Mn macro-oncoids are $43 \mathrm{~mm}$ mean-size. The coat is usually $<30 \mathrm{~mm}$ thick. The outer shape is irregular in outline, and sub-rounded, spheroidal to elongate. The nucleus (normally pebbles or ammonoid carcasses) controls the outer shape of the macro-oncoid. The internal structure of the Fe-Mn macro-oncoids is concentric, with partially overlapping laminae. The banded coatings are microbial laminated fabrics with planar and arborescent morphologies to dendrolitic morphologies. Alternation between these two fabrics reveals a rhythmic growth in the Fe-Mn macro-oncoids as a response to minor changes in sedimentation rate. The laminae range from $20-140 \mu \mathrm{m}$ thick. Under petrographic microscopy laminae pairs are seen to consist of a thicker clear lamina and a thinner dark lamina. Moreover, scarce calcareous laminae with pelagic sediment occur. The mineralogical composition of these banded crusts is goethite, calcite, lithiophorite, cryptomelane and phosphates. In general, the $\mathrm{Fe}_{2} \mathrm{O}_{3}$ proportion in the crusts is between 3 and 9 times the European Shale Composite (ESC) content. The mineral composition of the coating is goethite, calcite, lithiophorite and cryptomelane. In general, the chemical composition of the crusts is mainly dominated by $\mathrm{Fe}_{2} \mathrm{O}_{3}(\approx 40 \%)$ and $\mathrm{MnO}(\approx 20 \%)$. A strong enrichment in $\mathrm{Co}, \mathrm{Ni}$, As and $\mathrm{Sb}$ is observed.

Under petrographic microscope, the planar morphologies are constituted by condensed fibrillar meshworks with microspheres $(\sim 8 \mu \mathrm{m}$ in diameter) interpreted as cyanobacteria (under petrographic microscope) whereas the dendrolitic structures are similar to the problematic microfossil Frutexites.

Three types of microbial structures are registered in the internal lamination of FeMn macro-oncoids under SEM analyses: (1) coccoid-shaped forms $(\sim 2 \mu \mathrm{m})$ interpreted as cyanobacteria, (2) dense networks composed by straight flattened filaments $(5-10 \mu \mathrm{m}$ in diameter) with many dichotomous branching filaments inter- 
preted as chlorophycea or fungi, and (3) cylindrical filaments (2-3.5 $\mu \mathrm{m}$ in diameter) with irregular branching interpreted as multicellular hyphae forming a fungal mycelium. Agglutinated sessile foraminifera (Thurammina, Placopsilina and Tolypammina) have been occasionally recorded.

The precipitation of $\mathrm{Fe}-\mathrm{Mn}$ is interpreted in relation to chemoorganotrophic behaviour of the benthic microbial communities, mainly fungi. The key is in the $\mathrm{Mn}$ content of the crusts. It is well established that in modern environments efficient precipitation of $\mathrm{Mn}$ from natural water depends largely on the presence of Mn-oxidizing microorganisms (Buatier et al. 2004). Inorganic precipitation mechanisms are regarded as insufficient for accumulation of significant amount of $\mathrm{MnO}$ in natural environments. Sediment-starved zones of pelagic swells of External Subbetic, were favoured places for microbially mediated authigenesis. The hydrothermal influence is not excluded on the development of the Fe-Mn banded crusts, related to the contemporary volcanic processes accounted in the Median Subbetic (Vera et al. 1997).

\section{References}

Buatier, M. D.; Guillaume, D.; Wheat, C. G.; Hervé, L. \& Adatte, T. 2004. Mineralogical characterization and genesis of hydrothermal Mn oxides from the flank of the Juan de Fuca Ridge. American Mineralogists 89: 1807-1815.

Vera, J. A.; Molina, J. M.; Montero, P. \& Bea, F. 1997. Jurassic guyots in the Southern Iberian Continental Margin: a model of isolated carbonate platforms on volcanic submarine edifices. Terra Nova 9: 163-166.

\section{Sponge bioherms-microbial lithoherms from a Late Jurassic epiconti- nental shelf (External Prebetic, SE Spain) [poster]}

Matías Reolid

Departamento de Geología, Universidad de Jaén, Jaén, Spain; E-mail: mreolid@ujaen.es

Buildups registered in Upper Jurassic marly-limestone rhythmites and spongiolithic limestones from the External Prebetic (Betic Cordillera, SE Spain) are more or less massive, plano-convex to lens-shaped, with low relief (3.5 m high x $10 \mathrm{~m}$ long). Simple and complex buildups have been recognized, the latter consist of several smaller, stacked bodies, which are more or less lens-shaped and separated by sharp, plane or slightly convex, surfaces. The main components in these buildups are arranged in detail according to an elemental sequence made of: siliceous sponge (Dictyida), microbialite, and micritic sediment. Greater and complex buildups comprise two fundamental parts: a) the lower part (sponge bioherm) is less than $30 \mathrm{~cm}$ thick, consists of close-packed, dish-shaped sponges and shows the elemental sequence being scarce in microbialite; and b) the upper part, is thicker, contains a 
lower proportion of sponges per rock volume, and shows expanded elemental sequences rich in microbial encrustments (microbial lithoherm; Burne \& Moore 1987). This macroscopic sequence is, sometimes, capped by a higher proportion of fragmented sponges.

On the upper surface of the sponges, planar, and locally club-shaped, microbial growths are frequently registered. Examples exist of columnar growth from basal, planar mats. The macroscopical structuring of microbialites is structure-less (leiolites; Braga et al. 1995) or shows a laminated macrofabric (stromatolites). Under microscope, both leiolites and stromatolites constitute a microbial fabric, with laminated and massive organization. Laminated fabrics are predominant, and two types are differentiated depending on the most important biotic component: microbial laminated fabrics s. str. (benthic microbial communities or BMC) and nubeculariid laminated fabrics (BMC + nubeculariids).

In the central sector of the External Prebetic, the occurrence of sponge biohermmicrobial lithoherm buildups is related to episodic substrate colonization by pioneer sponges. The initial colonization would provide suitable surface for subsequent sponge growth and colonization by sessile organisms. Moreover, stabilized substrates provided by pioneer sponges would represent very favorable-to-optimal substrates for BMC promoting thick, microbial encrustation. This favorable situation facilitated a higher growth of BMC with respect to existing possibilities in the surrounding muddy bottom. This situation resulted in development of sponge bioherm-microbial lithoherm buildups. The sponge bioherm phase represents the initial phase of substrate colonization, while the microbial lithoherm corresponds to a later phase of BMC proliferation (leiolitos and stromatolites). Discontinuities bounding growth's cycles represent interruptions during unfavorable phases (environmental disturbances).

\section{References}

Braga, J. C.; Martín, J. M. \& Riding, R. 1995. Controls on microbial dome fabric development along a carbonate-siliciclastic shelf-basin transect, Miocene, SE Spain. Palaios 10: 347-361.

Burne, R. V. \& Moore, L. S. 1987. Microbialites: Organosedimentary deposits of benthic microbial communities. Palaios 2: 241-254.

\section{Tolypammina-Frutexites community of the Carnian Feuerkogel Hall- statt Facies - a microfacial and geochemical approach [talk]}

Marta Rodríguez-Martínez ${ }^{1}$, Christine Heim², Klaus Simon², Joachim Reitner ${ }^{2}$ \& Thomas Zilla ${ }^{2}$

${ }^{1}$ Departamento de Geología, Universidad de Alcalá, Alcalá de Henares, Madrid, España; E-mail: marta.rodriguezm@uah.es 
${ }^{2}$ Geowissenschaftliches Zentrum der Universität Göttingen, Abt. Geobiologie, Göttingen, Germany; E-mail: cheim@gwdg.de \& jreitne@gwdg.de

${ }^{3}$ Geowissenschaftliches Zentrum der Universität Göttingen, Abt. Geochemie, Göttingen, Germany; E-mail: ksimon@gwdg.de

Sessile foraminifers associated with ferromanganese crusts (FeMnC) have been recognized in pelagic condensed successions from Devonian, Triassic, Jurassic and Cretaceous records. However, the most spectacular example was described by Wendt (1969) in the Carnian Hallstatt Limestone from the Feuerkogel in the Juvavic nappe system of the Northern Calcareous Alps (NCA).

Fossil FeMnC share several features with Recent Mn/Fe-nodules, which are common deposits in pelagic sediments, formed on deep seamounts, ridges and plateaus areas with low sedimentation rates. They are heterogeneous mixtures of authigenic, biological and detrital materials dominated by the Fe-Mn oxyhydroxides, and with a diverse benthic fauna associated where foraminifers are the most abundant sessile organisms.

The Hallstatt Limestones of the NCA were deposited on salt-diapiric-induced structures in the so-called Hallstatt-Meliata Ocean. The Feuerkogel micro-reefs form a bed from 2 up to $20 \mathrm{~cm}$ of maximum thickness, where the FeMnC display a stromatolite-like structure. A progressive facies change occurs: (i) ondulose to wavy FeMnC-rich limestone from the base; (ii) Tolypammina gregaria-rich limestone toward the top. Biotic diversity increases toward the top where the maximum development of Frutexites occurs. Frutexites is a problematic microorganism, sometimes related with iron-oxidising bacteria or regarded as an organodiagenitic taxon (Myrow \& Coniglio 1991).

Laser-ICP-MS measurements of trace elements and REE were made to detect enrichment by detrital components (due to the coeval Reingraben Turnover (Hornung et al. 2007), related with the so-called Carnian Pluvial Event (Simms \& Ruffel 1989), as well as to differentiate between the possible hydrogenous, hydrothermal, diagenetic and/or mixed character of the Feuerkogel Tolypammina-Frutexites crust assemblage.

\section{References}

Hornung, T.; Spatzenegger, A. \& Joachimski, M. M. 2007. Multistratigraphy of condensed ammonoid beds of the Rappolstein (Berchtesgaden, southern Germany): unravelling palaeoenviromental conditions on 'Hallstatt deep swells' during the Reingraven Event (Late Lower Carnian). Facies 53: 267-292.

Myrow, P. M. \& Coniglio, M. 1991. Origin and diagenesis of Cryptobiontic Frutexites in the Chapel Island Formation (Vendian to Early Cambrian) of Southeast Newfoundland, Canada. Palaios 6: 572-585.

Simms, M. J. \& Ruffel, A. H. 1989. Synchroneity of climate change and extinctions in the Late Triassic. Geology 17: 265-258.

Wendt, J. 1969. Foraminiferen - „Riffe“ in karnischem Hallstätter Kalk des Feuerkogels (Steiermark, Österreich). Paläontologische Zeitschrift 43 (3/4): 177-193. 


\title{
Microbialites from the Cassian Formation: An insight [talk]
}

\author{
J. Francisco Sánchez-Beristáin \& Joachim Reitner \\ Geowissenschaftliches Zentrum, Universität Göttingen, Abt. Geobiologie, Göttingen, Germany; E-mail: \\ fsanche@gwdg.de_jreitne@gwdg.de
}

The nature of some sediments from the Cassian Formation (Lower Carnian, Upper Triassic) has been recently reconsidered or defined. This has been particularly valid for many of the so called "Cipit Boulders" (Keup et al. 1989; Russo et al. 1997), for which a mud mound nature has been assessed.

Microbialites constitute an important part of the Cassian sediments (Keupp et al. 1993; Neuweiler \& Reitner 1995) and they are frequently associated to sponges (Reitner 1993; Reitner et al. 1995; Keupp et al. 1993), which are a common skeletal component of the boundstones within cipit boulders. Three different types of microbialite - subsequently Type 1,2 and 3- have been identified as accretionary and container types according to the classification from Reitner et al. (1995). Type 1 has been already described as "dense micritic fenestral thrombolites" (Neuweiler \& Reitner 1995) and is the most abundant within the examined material. Type 2 is an accretionary organomicrite constituted by a dense stromatolithic fabric without fenestrae and is strongly associated to boundstones (bindstones) with the alga Dendronella articulata. Finally, Type 3 may be a container microbialite, since it grows in rather closed spaces and seems have been result of a decaying sponge.

All microbialites were examined with epifluorescence microscopy in order to determine their organic origin following the methodology of Neuweiler and Reitner (1995) and also display no luminescence when examined under Cathodoluminiscence, indicating a good preservation state, all of which confers the possibility of further biogeochemical and geochemical analyses to be performed on them.

\section{References}

Keupp, H.; Jenisch, A.; Herrmann, R.; Neuweiler, F. \& Reitner, J. 1993. Microbial Carbonate Crusts A key to the Environmental Analysis of Fossil Spongiolites? Facies 29: 41-54.

Keupp, H.; Reitner, J. \& Salomon, D. 1989. Kieselschwämme (Hexactinellida und „Lithistida“) aus den Cipit-Kalken der Cassianer Schichten (Karn, Südtirol). Berliner geowissenschaftliche Abhandlungen (A) 106: 221-241.

Neuweiler, F. \& Reitner, J. 1995. Epifluorescence microscopy of selected microbialites from Lower Carnian Cipit-boulders of the Cassian Formation (Seeland Alpe, Dolomites). In: Reitner, J. \& Neuweiler, F. (coord.): Mud Mounds: A polygenetic Spectrum of Fine-grained Carbonate Buildups. Facies 32: 26-28.

Reitner, J. 1993. Modern Cryptic Microbialite/Metazoan Facies from Lizard Island (Great Barrier Reef, Australia) Formation and Concepts. Facies 29: 3-40.

Reitner, J.; Neuweiler, F. \& Gautret, P. 1995. Modern and fossil automicrites: Implications for mud mound genesis. In: Reitner, J. \& Neuweiler, F. (coord.): Mud Mounds: A polygenetic Spectrum of Fine-grained Carbonate Buildups. Facies 32: 4-17. 
Russo, F.; Neri, C.; Mastandrea, A. \& Baracca, A. 1997. The Mud Mound Nature of the Cassian Platform Margins of the Dolomites. A Case History: the Cipit Boulders from Punta Grohmann (Sasso Piato Massif, Northern Italy). Facies 36: 25-36.

\title{
Fossil and Recent microbial associations from amber [talk]
}

\author{
Alexander R. Schmidt ${ }^{1} \&$ Christina Beimforde ${ }^{2}$ \\ ${ }^{1}$ Georg-August-Universität Göttingen, Courant Research Centre Geobiology, Göttingen, Germany; \\ E-mail: alexander.schmidt@geo.uni-goettingen.de \\ ${ }^{2}$ Georg-August-Universität Göttingen, Geoscience Centre, Department of Geobiology, Göttingen, \\ Germany; E-mail:cbeimfo@gwdg
}

Apart from arthropods and plant remnants, amber may contain diverse well-preserved fossil microorganisms. Associations of fossil bacteria, cyanobacteria, fungi, algae, protozoans and micrometazoans are known from various Mesozoic and Cenozoic resins. Most enclosed microorganisms are representatives of limnetic, limnetic-terrestrial, or at least humid microhabitats of the resin-bearing trees and of the forest floor.

For most microorganisms it is supposed that the taphotopes were located very close to or within their microhabitats. However, there are different ways how microbes may enter or become enclosed in liquid resins. Fungi may be introduced into the resin attached to insects, or at plant remnants. Some fungi and bacteria are even able to grow on liquid resin and also into it, and can therefore be found in almost every amber. Usually, these filaments are growing in random orientation as long as the resin is liquid. In humid environments, liquid tree resin may be colonized by dense mycelia and prokaryotic filaments. Growth stops when the resin solidifies, and sometimes, densely arranged filaments of bacteria and fungi cause opacity of outer parts of resin pieces.

To find aquatic organisms in tree resin may seem to be highly unlikely but the fossil record provides amber-preserved limnetic algae, ciliates, testate amoebae and rotifers. Limnetic microorganisms may get stuck or enclosed when resin gets contact to water or even flows into water. Three possibilities of embedding limnetic and limnetic-terrestrial organisms have been observed: (1) attaching to resin surface and struggling deeper, (2) overflowing by subaquatic resin, or (3) enclosing in tiny water drops in resin. Microorganisms are often arranged in clusters located at the former location of water drops in the resin. In this situation, unicellular and filiform algae, amoebae and ciliates occur close to each other in the amber.

Apart from fossil microorganisms which are entirely surrounded by resin, there occur living bacteria and fungi at the surface and in fissures of the amber pieces. 
The interactions of these modern microbes with the resin are still poorly understood. Probably some of them may use the fossil resin as a source.

\title{
Microbialite-sediment interactions on the slope of the Campbellrand carbonate platform (Neoarchean, South Africa) [poster]
}

\author{
Stefan Schröder ${ }^{1}$, Nic J. Beukes ${ }^{2} \&$ Dawn Y. Sumner ${ }^{3}$ \\ ${ }^{1}$ Paleoproterozoic Mineralization Research Group, Department of Geology, University of Johannesburg, \\ South Africa; presently at: Total E\&P, Pau, France; E-mail: stefan.schroeder@total.com \\ ${ }^{2}$ Paleoproterozoic Mineralization Research Group, Department of Geology, University of Johannesburg, \\ South_Africa; E-mail:nbenkes@uj.ac.za \\ ${ }^{3}$ Department of Geology, University of California at Davis, Davis, USA; E-mail: \\ sumner@geology.ucdavis.edu
}

Microbialite-resedimented dolostone cycles form a prominent part of slope facies for the 2.6-2.5 Ga Campbellrand carbonate platform, Transvaal Supergroup, South Africa. The cycles allow a study of microbialite-environment interaction decoupled from direct influence of relative sea level variations, which play an important role in shallow-water settings.

Microbialite types range from delicate cuspate forms (Sumner 1997) to stratiform and incipient columnar microbialites. Resedimented facies include (a) dolarenites, (b) massive to laminated dolostones, (c) dolomite laminites, and (d) lumpy dolostones with roll-up structures. On a $\mathrm{cm}$ - and $\mathrm{dm}$-scale, microbial and resedimented facies are arranged into symmetric or asymmetric microbialite cycles with resedimented facies commonly grading upward into microbialite facies. Cycles are transitional between a microbialite-dominated end member with almost no evidence for clastic carbonate sedimentation, and a sediment-dominated end member where microbialite relief is strongly subdued and clastic carbonate makes up most of the cycle thickness. The microbialite-dominated cycles are remarkably uniform on the platform slope. Systematic variation in cycle architecture leads to $\mathrm{dm}$-scale stacked microbialite cycles, which in turn form the main building blocks of m-thick microbial units. On the scale of decameter-thick sequences, microbial units pass upwards to progressively thicker units dominated by resedimented slope carbonates.

Microbialite cycles show a distinct inverse relationship between the development of microbial structures and the abundance of detrital carbonate sediment in cycles. Thus, cyclicity is interpreted as primarily controlled by variations in sediment influx. Additional, although poorly constrained factors, may include changes in community structure and lithification of microbialites via direct carbonate precipitation. Given the deep depositional environment and stratigraphic distribution of cycles, slope cyclicity seems to have been subject to a strong allocyclic control, with 
external factors changing simultaneously and across most of the slope. On the largest scales, sediment influx was probably controlled by sediment export off the upper slope and, to a lesser degree, the platform margin.

\section{References}

Sumner, D. Y. 1997. Late Archean calcite-microbe interactions: two morphologically distinct microbial communities that affected calcite nucleation differently. Palaios 12: 302-318.

\section{Characterisation of the microbial community in an abandoned uranium mine [poster]}

Jana Seifert ${ }^{1}$, Beate Erler ${ }^{1}$, Kathrin Seibt ${ }^{1}$, Nina Rohrbach ${ }^{1}$, Janine Arnold ${ }^{1}$, Michael Schlömann ${ }^{1}$, Andrea Kassahun² \& Ulf Jenk ${ }^{3}$

${ }^{1}$ TU Bergakademie Freiberg, Institute of Biosciences, Environmental Microbiology, Freiberg, Germany;

E-mail:jana.seifert@ioez.tu-freiberg.de

${ }^{2}$ Groundwater Research Institute Dresden, Dresden, Germany; E-mail: akassabun@dgfz.de

${ }^{3}$ Wismut GmbH, Chemnitz, Germany; E-mail: u.jenk@wismut.de

In the following project the autochthonous microbial community of various samples from the abandoned uranium mine had to be characterized and analysed in respect to their bioremediation potential of inorganic pollutants. The mine is located in Königstein near Dresden and has a depth of about $200 \mathrm{~m}$ at a territory of about $4.5 \mathrm{~km}^{2}$. The uranium production was mainly achieved by an in situ leaching on the sandstone with sulphuric acid. Another sulphuric acid release is caused by pyrite oxidation in the mine. These reactions change the geochemical nature of the deposit increasing the level of pollution mainly with sulphate, heavy metals and radionuclides. The polluted mine water is a potential hazard for the adjacent groundwater and thus the discharge of the pollutants has to be to minimized.

Cultivation-independent methods, like fluorescence in situ hybridisation (FISH) and terminal restriction fragment length polymorphism (T-RFLP) were used to screen various water and sludge samples for a first insight. Three samples were investigated in more detail by bacterial diversity analyses (16S rDNA clone libraries): water from an open drainage canal, sandstone and anoxic sludge.

The water sample showed a dominance of acidophilic, autotrophic, iron oxidizing bacteria belonging to the Betaproteobacteria. These bacteria are associated with heterotrophic acidophiles, like Alicyclobacillus sp. and Acidobacteria sp. In contrast, the bacterial communities of the sandstone and sludge sample were more diverse. Most of the sequences were closely related to uncultivated bacteria obtained from 
diversity analyses of various environmental samples. Major sequence groups belong to the Deltaproteobacteria class, like Desulfovibrio, Desulfobacca, Desulfomonile and Synthrophobacter species, and to the Firmicutes class, like Desulfosporosinus and Desulfitobacterium species. Thus, autochthonous sulphate reducing bacteria were detected in the mine. Enhanced natural attenuation can be achieved stimulating the activity of these microorganisms and resulting in an inhibited discharge of the pollutants by the flooding of the mine.

\section{The microbial mats as a principal factor in the variable preservation of Vendian fossils: the taphonomic evidence [poster]}

Ekaterina A. Serezhnikova

Paleontological Institute, Russian Academy of Sciences, Moscow, Russia; E-mail: serezhnikova@paleo.ru

Widespread microbial mats on the ocean floor and minor bioturbation are common for the terminal Proterozoic environments. Vendian fossils are characterized by very wide spectrum of preservation due to lack of tissue mineralization and non-actualistic conditions of the formation. The classical explanation for the unique ediacaran fossilization is the "death mask" resulted from bacterial precipitation of iron minerals (Gehling 1999); the same mode of preservation was recognized early for palaeobotanical objects (Krishtophovich 1957; Dunn et al. 1997). However the traces of the iron mineralization are very rare on the surfaces of the ediacaran fossils, the framboids and isolated crystals of pyrite on the top of some Vendian imprints from the White Sea (Dzik 2003) is an exception to the rule. Indirect evidence of "iron death mask" is the presence of thin haematite/clay coating on the hyporelief surfaces of the attached disks from the Amadeus Basin, Australia (Mapstone \& McIlroy 2006).

The taphonomic variability of the Vendian fossils was studied on the great number of specimens of one type collected from single depositional surface. It was recognized that some organisms could be preserved as a kind of cross-section on the random horizontal surface of the fossiliferous layer. For example, Palaeophragmodictya spinosa Serezhnikova, 2007, the commonest impression in the Solza locality, the Southeastern White Sea Region is a composite mold where the outer zone with thin radial structures reflects the lower surface of the attachment disc, whereas the central part is the negative cast of the internal cavity. The existence of this cavity is suggested by occasional specimens, the central part of which is filled with sediment. Apparently, in rare cases, by the time of lithification, the organic material of the inner cavity had not decayed completely, possibly resulting in various forms of preservation of the central parts of impressions. The specimen with a negative outer zone and mesh structures, apparently external molds of the upper surface of the attachment disc, is unique to this locality. Thus, variability observed in Palaeo- 
phragmodictya from the White Sea Region gives a mosaic view about the structure of the fossilized part of the body. It's difficult to explain the presence of multiple preservation morphs of three dimensional organisms in the form of cross-sections by formation of "Iron death mask" on the surface of the collapsing bodies. The other way of such unique fossilization is the rapid consolidation of thin fossiliferous layer due to carbonate cementation. For example, carbonate accounts for $1-3 \%$ of sandstone, but $32 \%$ in some siltstone in the fossiliferous Neoproterozoic Arumbera Sandstone, Australia (Mapstone \& McIlroy 2006); the carbonate clay amounts to $10-15 \%$ in the Solza locality, the Southeastern White Sea Region. Calcium carbonate was found in cyanobacterial films developing on the modern beaches of the North Sea barrier island Schiermonnikoog, the Netherlands (Kremer et al. 2008). The precipitation of carbonate could be proposed for Vendian microbial mat environments, but the grains can disappear completely because of dissolution that is typical of anoxic conditions. Thus, the variable preservation of the Vendian fossils can be explained by the rapid cementation of the thin fossiliferous layer due to carbonate cementation.

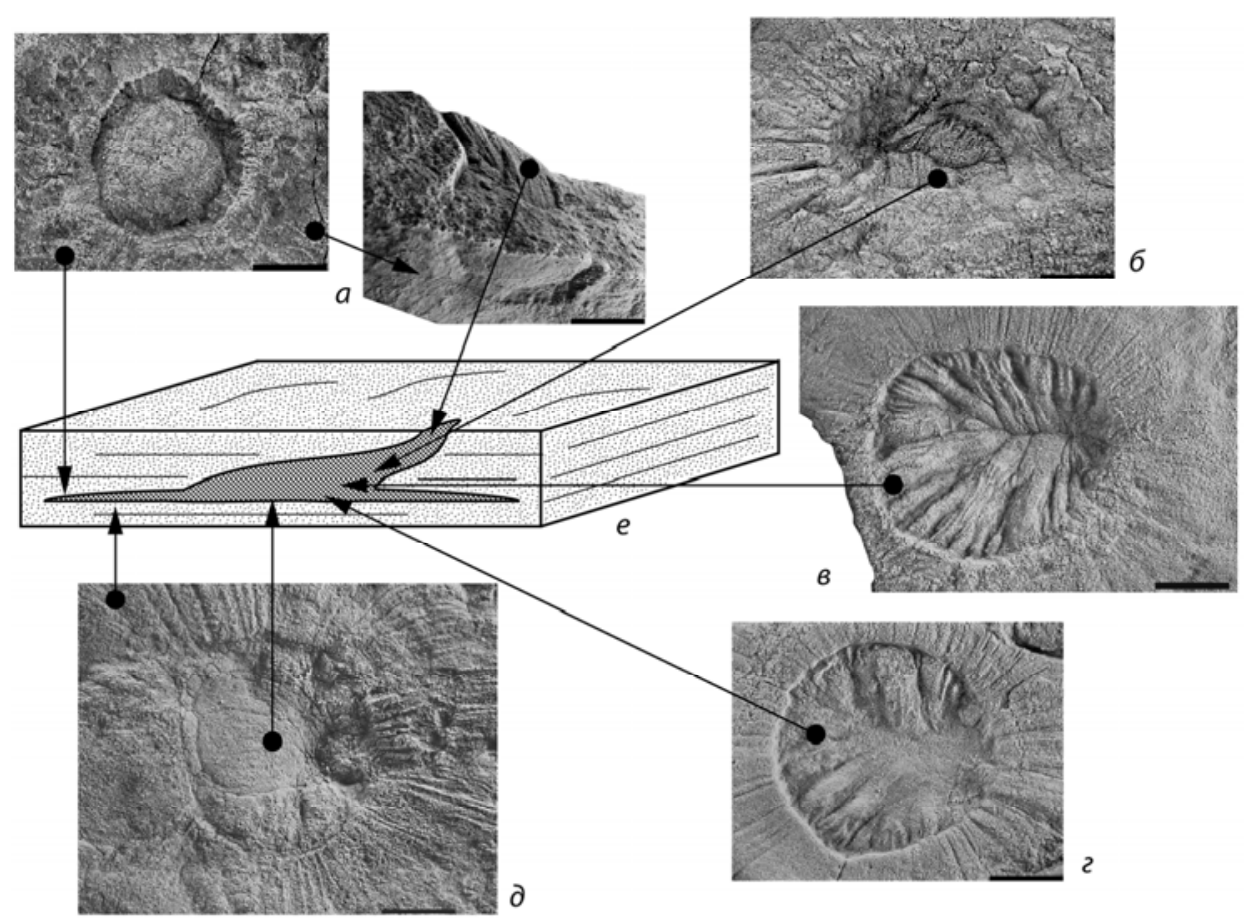

Fig. 1. Preservational morphs of Palaeophragmodictya spinosa, Arkhangelsk Region, Onega Peninsula, Solza River; Upper Vendian, Verkhovka Formation; specimens PIN, nos. (a) 4853/425; (6) 4853/412; (в) 4853/416; (2) 4853/415; ( $)$ 4853/424; and (e) drawing of the fossilized part of the organism. Scale bar: $1 \mathrm{~cm}$. 


\section{References}

Dunn, K. A.; McLean, R. J. C.; Upchurch, G. R. \& Folk, R. L. 1997. Enhancement of leaf fossilization potential by bacterial biofilms. Geology 25: 1119-1122.

Dzik, J. 2003. Anatomical information content in the Ediacaran fossils and their possible zoological affinities. Integrative and Comparative Biology 43 (1): 114-126.

Gehling, J. G. 1999. Microbial mats in terminal Proterozoic siliciclastics: Ediacaran death masks. Palaios 14 (1): 40-57.

Kremer, B.; Kazmierczak, J. \& Stal, L. J. 2008. Calcium carbonate precipitation in cyanobacterial mats from sandy tidal flats of the North Sea. Geobiology 6: 46-56.

Mapstone, N. B. \& Mcllroy, D. 2006. Ediacaran fossil preservation: Taphonomy and diagenesis of a discoid biota from the Amadeus Basin, central Australia. Precambrian Research 149: 126-148.

\section{Photosynthesis-induced stromatolite formation [talk]}

Fumito Shiraishi ${ }^{*}$, Andrew Bissett ${ }^{2}$, Dirk de Beer ${ }^{2}$, Barbara Zippel ${ }^{3}$, Thomas R. $\mathrm{Neu}^{3}$, Andreas Reimer ${ }^{1} \&$ Gernot Arp ${ }^{1}$

${ }^{1}$ Geoscience Centre, University of Göttingen, Department of Geobiology, Göttingen, Germany; E-mail: fshirai@gwdg.de

${ }^{2}$ Max-Planck-Institute for Marine Microbiology, Bremen, Germany; E-mail: abissett@mpi-bremen.de \& dbeer@mpi-bremen.de

${ }^{3}$ Helmboltz. Centre for Environmental Research - UFZ, Department of River Ecology, Magdeburg,

Germany; E-mail: Barbara.zippel@ufz.de \& thomas.neu@ufz.de

*Present address: Department of Earth and Planetary Systems Science, Graduate School of Science, Hiroshima University, Higashi-Hiroshima,Japan; E-mail:fshirai@hiroshima-u.ac.jp

Recent freshwater stromatolites developing at the karst creeks were investigated in order to understand the formation mechanisms of stromatolite in detail. Thin sectioning and molecular microbiological investigations (FISH and CARD-FISH) showed that the stromatolite biofilms composed mainly of filamentous cyanobacteria as well as a number of heterotrophic bacteria (Shiraishi, Zippel et al. 2008). $\mathrm{pH}, \mathrm{O}_{2}, \mathrm{Ca}^{2+}$ and $\mathrm{CO}_{3}{ }^{2-}$ microelectrode measurements were performed to check the metabolic effect(s) of these biofilms on the stromatolite formation, and revealed that photosynthetic activity of stromatolite biofilms strongly induces calcite precipitation under illumination, while respiration inhibits precipitation in the dark (Shiraishi, Bissett et al. 2008; Shiraishi, Reimer et al. 2008). From kinetic point of view, photosynthesis is very important mechanism for carbonate precipitation.

However, such photosynthesis-induced carbonate precipitation is not common phenomenon at least in the recent ocean, which is obvious from the fact that not all of aqueous phototrophs are calcifying. On the other hand, it would be widespread during Proterozoic and certain periods of Phanerozoic Ocean when micro- 
bial carbonates were common. In order to understand the precondition of photosynthesis-induced carbonate precipitation, chemical simulations were therefore conducted. These examinations revealed that there are several important preconditions such as optimum $\mathrm{pH}-\mathrm{DIC}$ condition, not extremely low $\left[\mathrm{Ca}^{2+}\right]$, low ionic strength and sufficient photosynthetic activity, in addition to sufficient surrounding supersaturation, the widely accepted precondition for microbial carbonate precipitation (Arp et al. 2001).

These additional preconditions are important for understanding stromatolite formation throughout the Earth history. If we assume that stromatolites were mainly formed by photosynthesis-induced precipitation after the development of oxygenproducing photosynthesis at $2.7 \mathrm{Ga}$, it is possible to explain not only the secular variation of stromatolite, but also that of inorganic carbonates that exhibit different pattern, by the change of seawater chemistry. Although the effect(s) of other factors such as life evolution, replacement of dominant microorganisms in the stromatolite biofilms and other calcification mechanisms should be considered, photosynthesis must be one of important mechanisms for stromatolite formation throughout the Earth history.

Acknowledgements: This project is the part of the Research Unit 571 "Geobiology of organo- and biofilms", funded by the German Research Foundation (DFG-FOR 571; AR 335/5; publication \#34).

\title{
References
}

Arp, G.; Reimer, A. \& Reitner, J. 2001. Photosynthesis-induced biofilm calcification and calcium concentrations in Phanerozoic oceans. Science 292: 1701-1704.

Shiraishi, F.; Bissett, A.; Beer, D. de; Reimer, A. \& Arp, G. 2008. Photosynthesis, respiration and exopolymer calcium-binding in biofilm calcification (Westerhöfer and Deinschwanger Bach, Germany). Geomicrobiology Journal 25: 83-94.

Shiraishi, F.; Reimer, A.; Bissett, A.; Beer, D. de \& Arp, G. 2008. Microbial effects on biofilm calcification, ambient water chemistry and stable isotope records (Westerhöfer Bach, Germany). Palaeogeography, Palaeoclimatology, Palaeoecology 262: 91-106.

Shiraishi, F.; Zippel, B.; Neu, T. R. \& Arp, G. 2008. In situ detection of bacteria in calcified biofilms using FISH and CARD-FISH. Journal of Microbiological Methods. DOI: 10.1016/j.mimet.2008.05.015.

\section{Are the stromatolites the most ancient skeleton organisms? [poster]}

\author{
Evgenia Sumina $^{1}$, Vladimir K. Orleansky ${ }^{1} \&$ D. Sumin ${ }^{2}$ \\ ${ }^{1}$ Paleontological Institute RAS, Moscow, Russia; E-mail:stromatolit@list.ru\&orleanor@mail.ru \\ ${ }^{2}$ Independent researcher, Moscow, Russia
}

The stromatolites have an ancient and contradictious research history. At first they be accounted as nonorganic fossiles - concretion or layer limestone. Since time 
was established their organic nature the position of stromatolites and stromatoliteformers was not determined. At 1914 C. Walcott supported that stromatolites are produced by blue-green algae (cyanobacteria) and at thirties of last century it was confirmed by the recent investigation of stromatolite forming microbiot. Since that time as stromatolite-former is considering as a colony of microorganisms with stromatolite as a result of interaction between colony and falling sediment. Such the consideration of stromatolite nature was successfully used at Precambrian stratigraphy is a manner of eucaryot organisms in research of geology history. But on the other hand stromatolite-former was never considered as an organism and was completely denied the possibility of relative large multicellular existence organism-line structures with prokaryotic base. So arise a controversy between biological object features: it is impossibility for macroscopical morphogenesis (at stromatolites proportion), but capable to form morphologically completed, time and space-stable macro size body. To avoid such a controversy the laboratory modelling research was fulfilled for the stromatolite-forming (Orleanskij \& Raaben 1997). To continue this experiment were fulfilled for de separated research of a morphogenetic reaction society (society means a compact settlement of independent elements (cyanobacteria filaments) with non determined degree of integrity) of contemporary filamentous cyanobacteria as a whole unity.

Ten types of structure were detected for filaments cyanobacteria creation as a result of their regrouping (Sumina 2002). The form of the structures is specific and arise as a behaviour reply on various influences and sum times arise to $10 \mathrm{sm}$ dimension. As a result society is able to macroscopically- size differentiation and morphogenesis. Accordingly the stromatolit was considered as a society morphogenesis replay in presence of mineral sediment. We are considering this body as basic mineral creation of morphogenesis becomes form-creation and history-developing of stromatolite is corresponding to a photosynthesis function realization requirements for a stromatolite-former.

So the stromatolites are suitable to produce eucaryotic organism skeletons. As a confirmation may be also considered the coordination, concordance and dependence of morphology features evolution variations up to upper Precambrian. The comparison of stromatolite and eucaryot skeletons shows total and fundamental features of skeletons - morphological definity, hierarchy organized, definition and stase-processing of evolution. But the direct comparison for stromatolites and eucaryotic skeletons is impossible because it's prokaryotic nature.

This work was supported by RFBR №080400484.

\section{References}

Орлеанский, В. К. \& Раабен, М. Е. [Orleanskij, V. К. \& Raaben, М. Е.] 1997. Живая мабораторная модель - аналог пассивно-ветвящихся столбчатых строматолитов. [Živaā laboratornaā model' - analog passivno-vetvāŝihsā stolbčatyh stromatolitov.] Aльгология [Al'gologiā] 7 (2): 185 188.

Sumina, E. L. 2002. Laboratory observation on culture of cyanobacteria and problem of stromatolites morphogenesis. Procceedings of SPIE 4939: 101-102; Bellingham. 


\title{
Formation of lamination in modern stromatolites from Lagoa Vermelha and Lagoa Salgada, Rio de Janeiro, Brazil: An example for Precambrian relics? [talk]
}

Crisogono Vasconcelos ${ }^{1}$, Pieter T. Visscher ${ }^{2}$, Maria Dittrich ${ }^{1}$, Tomaso Bontognali ${ }^{1}$ \& Judith A. McKenzie ${ }^{1}$

\author{
${ }^{1}$ Geological Institute, ETH Zürich, CH 8092 Zurich, Switzerland; E-mail: \\ cris.vasconcelos@erdw.ethz.ch,dittrich@eawag.ch,tomaso.bontognali@erdw.ethz.cheo \\ judy.mckenzie@erdw.ethz.ch \\ ${ }^{2}$ Center for Integrative Geosciences, University of Connecticut, Storrs, CT, US A; E-mail: \\ pieter.visscher@uconn.edu
}

Laminated structures in the rock record constitute some of the oldest evidence for life on Earth, but the processes forming stromatolitic lamination is still poorly understood. Recent studies conducted on modern Bahamian stromatolites attributed the lamination pattern to a combination of trapping and binding processes and in situ precipitation. These stromatolites have been proposed as a modern analogue for ancient forms; however, the textural component does not necessarily match that of Precambrian stromatolites.

Herein, we report on the first recognized occurrence of stromatolitic structures, associated with Ca-dolomite, growing in a hypersaline coastal lagoon, Lagoa Vermelha and Lagoa Salgada, Rio de Janeiro, Brazil. Mineralogical and geochemical characteristics of these living stromatolites indicate the presence of a diverse symbiotic association resulting in calicification. The balance between precipitation and dissolution is controlled by biogeochemical gradients within the uppermost microbial mat, which, together with mat accretion and subsequent degradation of extracellular polymeric substances (EPS), apparently leads to a defined lamination pattern.

Analytical transmission electron microcopy plus electron energy loss spectroscopy (TEM-EELS), X-ray microscopy and scanning electron and laser microscopic studies provide information about the biomineralization processes and associated metabolic mechanisms, such as photosynthesis, aerobic and anaerobic respiration, methanogenesis and fermentation. Despite the high diversity and similarity detected in the microbial mat from Lagoa Vermelha and Lagoa Salgada, the carbon isotope compositions of lamina show very distinctive $\delta^{13} \mathrm{C}$ values of $-5 \%$ and $+20 \%$, respectively. These modern examples reveal that the lamination formation is due to a slow complex mechanism, which combines the calcification budget with carbonate precipitation on EPS under anaerobic conditions. 


\section{Coelobiontic communities in neptunian fractures in Permian reef complexes, southern Urals, Russia [poster]}

Emmanuelle Vennin, Matthieu Deville de Periere, A. Guillemenet, Christophe Durlet \& Michel Guiraud

UMR 5561 Biogéosciences, Université de Bourgogne,Dijon, France; E-mail: emmanuelle.vennin@ubourgogne.fr, matthieu.deville-de-periere@u-bourgogne.fr, christophe.durlet@u-bourgogne.fr_o michel.guiraud@u-bourgogne.fr

The Permian reef complexes of the Russian platform provide an instructive example of the interaction between carbonate accumulation and tectonic events. Sedimentary fractures in these reef complexes are well preserved and important in providing information about reef growth, the biota, and particularly cavity-dwelling organisms and sediment sources. The fractures are oblique fractures, joints of shearing (generally grouped in dihedrons) and re-opened stratification joints. These contemporaneous fracture sets present orientations corresponding to the regional tectonic fabric and a tectonic origin for fracturing associated with the foreland basin development. They act as sediment traps for loose skeletal materials from the reef surface and act as niches for autochthonous biota (Archaeolithoporella, microbialites, rare ostracodes and gastropods). Eleven lithofacies and several stages of opening are recorded in the largest fractures and grouped in 3 main infill type successions: (1) type 1: dominated by mud supported microfacies (pelloidal wackestones, grey mudstones...), microbialites and monogenic breccias; (2) type 2: dominated by microbialites, grain supported microfacies (packstone of sponge spicules, grainstone composed of crinoids...) and polygenic breccias; and (3) type 3: composed of the Artinskian Cladoconus marls. The infillings are clearly synsedimentary and take place per-descensum. The submarine origin of the filled is evidences by the consistent occurrence of fibrous calcite cements of marine origin (Zempolich et al. 2002; Vennin et al. 2002). Biostratigraphically significant fossils in the fractures date the ages of the host rock and of the fissure formation and filling from late Asselian to upper Artinskian.

Two general types of microbial fabrics are commonly recognized and preceded filling by skeletal and terrigenous sediments: (1) Stromatoids and (2) centimetrethick deposits of peloidal grainstones to packstones (thromboids), which form in situ within microbial laminae on the fissure walls. The fissures contain a wellpreserved biota similar to the Lower Permian cavity-dwelling organisms observed within the reef. The coelobiontic habitat was episodically enlarged by successive synsedimentary fracturing episodes reflecting several phases of encrustation and infill of recurrent lithofacies. The pioneer microbialites grew when nothing else was deposited in the fissures immediately after fracturing. Crinoids, bryozoans, Tubiphytes, conodonts, brachiopods, ammonoids, and spiculate sponges are also found within fractures as reworked shells and skeletons, indicating that they were washed in from the overlying, open seafloor. The biota in the dykes is mainly represented by the dweller guilds living on the reef surface, whereas members of 
the binding and frame building guilds are poorly represented. The dykes form during reef development and the last stage of marl sedimentation within the fractures is related to a major flooding event corresponding to upper Artinskian drowning of the Russian Platform.

\title{
References
}

Vennin, E.; Boisseau, T.; Proust, J. N. \& Chuvashov, B. I. 2002. Influence of sea level change on reef architecture in Early Permian buildup complexes, southern Urals, Russia. In: Zempolich, W. G. \& Cook, H. E. (eds): Carbonate Reservoir and Carbonate Field Analogs. SEPM Special Publication 74: 205-218.

Zempolich, W. G.; Cook, H. E.; Viacheslav, G.; Zhemchuzhnikov, V. G.; Zorin, A.; Giovannelli, A.; Viaggi, M.; Lehmann, P. J.; Fretwell, N.; Zhaimina, V. Y. A.; Buvtyshkin, V. M. \& Alexeiev, D. V. 2002. The role of biotic and abiotic constituents in the development and diagenesis of middle to late Paleozoic carbonate platform: outcrops and subsurface examples from the C.I.S. In: Zempolich, W. G. \& Cook, H. E. (eds): Carbonate Reservoir and Carbonate Field Analogs. SEPM Special Publication 74: 123-180.

\section{Microbialite-Vermetid Community (Salento Peninsula, southern Italy): a Late Miocene Example of Automicrite Deposition in Confined Spaces [poster]}

\author{
Alessandro Vescogni ${ }^{1}$, Adriano Guido 2 , Adelaide Mastandrea ${ }^{2} \&$ Franco Russo $^{2}$ \\ ${ }^{1}$ Dipartimento di Scienze della Terra, Università di Modena e Reggio Emilia, Modena, Italy; E-mail: \\ alessandro.vescogni@unimore.it \\ ${ }^{2}$ Dipartimento di Scienze della Terra, Università della Calabria, Rende (CS), Italy; E-mail: \\ aguido@unical.it,a.mast@unical.itぬf.russo@unical.it
}

An unusual carbonate facies, constituted mainly of vermetid shells and micrites, has been described from an early Messinian reef complex outcropping in the Salento Peninsula (southern Italy) (Bosellini et al. 2002). The main purpose of this research is to give an account of the origin of this association. Vermetid-micritic facies crops out at the base of the reef complex with a thickness of $2.5 \mathrm{~m}$. The carbonate fabric is a wackestone-packstone with skeletal grains represented by vermetids and subordinately by smaller bioclastics. Vermetids in life position, which directly encrust the pre-Miocene substrate, are represented by a Petaloconchus monogeneric association, with sparsely distributed individuals, sometimes forming small aggregates. Most of the vermetids show the presence of a "feeding tube", an unwound extension of the shell which can be broken and rebuilt with different orientation, in order to cope with environmental disturbances. The facies of Petaloconchus passes upward into a clinostratified vermetid accumulations, characterized by broken isooriented feeding tubes, which form deposits parallel to the stratification. 
Optical, epifluorescence, SEM observations and EDS microanalyses, have been carried out in order characterize the micritic fraction. Three types of micrite are recognized: (a) fluorescent automicrite, with dense, aphanitic and rich in fine bioclastic grains (Fig. 1c-d); (b) fluorescent thrombolitic peloidal micrite (Fig. 1ab); (b) low fluorescent detritic micrite with gravitative fabric (Reitner \& Neuweiler 1995).
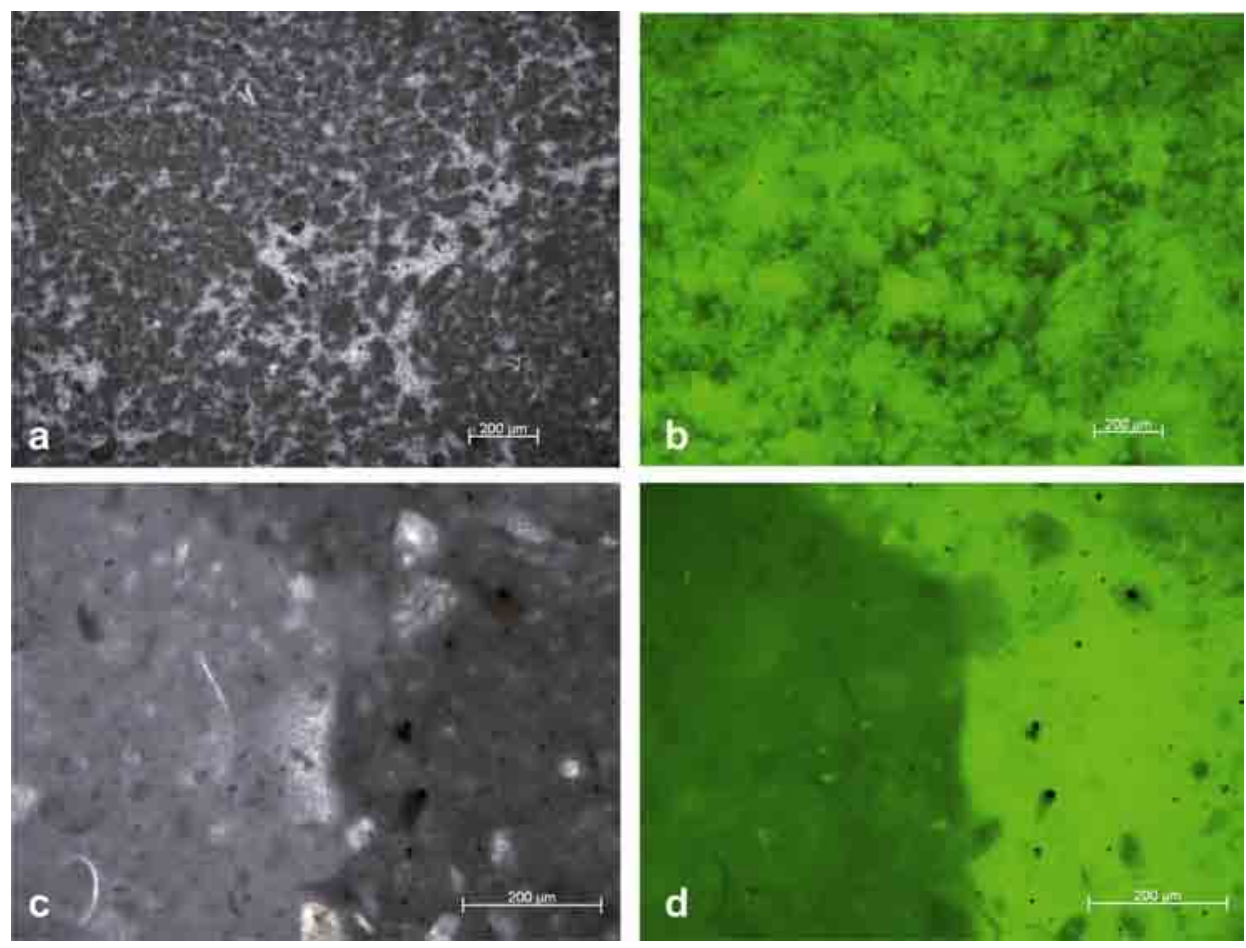

Fig. 1. Photomicrographs of the three type of micrites. (a-b). Thrombolitic peloidal: a, transmitted light; b, epifluorescence UV. (c-d). detritic (left) and aphanitic (right): c, transmitted light; d, epifluorescence UV.

On the basis of these data, is possible to recognize two different phases, which led to the deposition of the vermetid-micritic community:

- Vermetids colonization and accumulation of detritic micrite. This phase starts with the colonization of the vermetid community. Subsequently, periodical inputs of detritic micrite occurred, which forced vermetids to produce remarkably long, upward oriented, feeding tubes in order to avoid to be buried by sedimentation.

- Deposition of isooriented vermetid facies and accumulation of automicrite aphanitic and thrombolitic. The isooriented setting of vermetid conchs is here interpreted as the result of a slight redeposition of the previous colonizations, due to overloading or to other destabilizing processes. Actually, vermetid ecological demands do not 
support a way of life within a muddy substrate; therefore, automicrite deposition probably happened after the death of the vermetid community.

Automicrite represents the larger part of the micritic sediments within isooriented vermetids, its presence is associated to the occurrence of large amount of decaying organic matter. The source of this organic matter could be related to the synchronous death of a great number of Petaloconchus individuals, possibly associated with the disturbance of their growth substrate.

\title{
References
}

Bosellini, F. R.; Russo, A. \& Vescogni, A. 2002. The Messinian Reef Complex of the Salento Peninsula (southern Italy). Stratigraphy, Facies and Palaeoenvironmental Interpretation. Facies 47: 91-112.

Reitner, J. \& Neuweiler, F. 1995. Mud Mounds: A Polygenetic Spectrum of Fine-grained Carbonate Buildups. Facies 32: 1-70.

\section{The role of anoxygenic photosynthesis in carbonate deposition of modern- and possibly Precambrian stromatolites [talk]}

\author{
Rolf Warthmann
}

\section{Geological Institute, ETH Zürich, Zurich, Switzerland; E-mail: R.Warthmann@gmail.com}

Carbonate mineral formation in stromatolites and laminated microbial mats is still a subject of debate. Laminated structures found in sedimentary rocks of the Warrawoona Group, Western Australia $(3.5 \mathrm{Ga}$ ) provide evidence of very early microbially-mediated carbonate layers. However, the microbial impact on the formation can rarely be proven since fossilized organisms and geochemical traces are missing. Recent studies performed in an environmental setting considered to be an analogue for the Archean could supply new evidence of participation of specific microorganisms, regarded as "living fossils". Anoxygenic photosynthetic sulfur bacteria are considered to be one of the oldest forms of life and are abundantly present today in microbial mats from the hypersaline Lagoa Vermelha, Brazil. Studies on recent living and calcifying stromatolites, artificial anaerobic microbial mats and pure culture experiments show that purple sulfur bacteria may play an important role in the calcification process.

These findings expand our understanding of carbonate biomineralization and stromatolite formation in early anoxic ecosystems. In summary, even before the evolution of oxygenic photosynthesis, anaerobic sulfur bacteria may have contributed to the formation of bio-mediated carbonates resulting in the well-known lamination of microbial mats and stromatolite structures. 


\title{
Participation of sulphate reducing bacteria in formation of carbonates [poster]
}

\author{
Dorota Wolicka ${ }^{1} \&$ Andrzej Borkowski ${ }^{2}$ \\ ${ }^{1}$ Institute of Geochemistry, Mineralogy and Petrology, Faculty of Geology, University of Warsaw, Warsaw, \\ Poland; E-mail:d.wolicka@uw.edu.pl \\ ${ }^{2}$ Institute of Agricultural Microbiology, Faculty of Agriculture and Biology, Warsaw Agricultural \\ University, Warsaw, Poland
}

Precipitation of carbonates is strictly linked with the activity of both micro- and macroorganisms. Most of bacteria which are capable of inducing carbonates precipitation exist in oxic and anoxic environmental conditions. Temperature, salinity, depth belong to important factors affecting the formation of carbonates. Biological precipitation of carbonates is the result of activity of the different groups of microorganisms. This process can be induced by photosynthesis which is conducted by Cyanobacteria and phototrophic bacteria. In the strictly anaerobic condition, the activity of sulphate reducing bacteria (SRB) may by responsible for the formation of carbonates (Dupraz \& Visscher 2005). Biological sulphate reduction is very important process. SRB play the main role in the environments rich in organic matter and sulphates like marine deposits (Postgate 1984). These bacteria can utilize organic compounds and reduce sulphate to sulphide. The most of mixed populations of sulphate reducing bacteria have the ability to induction of the carbonates precipitation (calcite, dolomite, siderite) (Peckmann et al. 1999; Perry \& Taylor 2006; Warthman et al. 2000; Wright 1999) according to reaction:

$$
2\left[\mathrm{CH}_{2} \mathrm{O}\right]+\mathrm{SO}_{4}^{2-}+\mathrm{OH}^{-}+\mathrm{Ca}^{+2} \rightarrow \underline{\mathrm{CaCO}_{3}}+\mathrm{CO}_{2}+\mathrm{H}_{2} \mathrm{O}+\text { HS- }
$$

The bacterial communities were isolated from mud and multiplied using the method of microcosms. The cultures were incubated at room temperature of about $20^{\circ} \mathrm{C}$. A modified Postgate medium (Postgate 1984), without an yeast extract and sodium citrate, has been used. The second medium was a minimal one $(1 \mathrm{~g} / 1$ $\left.\mathrm{NH}_{4} \mathrm{Cl}\right)$. Both media were enriched with sodium lactate $98 \%(6 \mathrm{ml} / \mathrm{l})$ and/or ethanol $(3 \mathrm{ml} / \mathrm{l})$ as source of carbon. Resazurin in the concentration $0.001 \mathrm{~g} / \mathrm{L}$ was added to all cultures as an indicator of redox conditions in the medium. Sulfates in the cultures were determined with the hot barium method, COD by the dichromate method. Determinations involving post-culture sediments and fluids were made using X-ray analysis using a DRON-2 X-ray diffractometer. A total of 16 cultures were established: 8 on Postgate and 8 on minimal medium.

Generally, a higher activity of the isolated communities was observed on the Postgate medium than on the minimal one. The highest sulphate reduction (about $2400 \mathrm{mg} / \mathrm{l}$ ) was noted in cultures on a medium with ethanol as the sole carbon source. Based on calculations, the content of sulphates reduced by SRB reaches almost $95 \%$. A distinctly lower activity was noted in communities isolated on minimal medium. After the incubation, the diffractometric analysis of the post- 
culture sediments has been performed. The sediment contained carbonates being the by-product of SRB activity.

\title{
References
}

Dupraz, C. \& Visscher, P. T. 2005. Microbial lithification in marine stromatolites and hypersaline mats. Trends in Microbiology 13: 429-438.

Peckmann, J.; Thiel, V.; Michaelis, W.; Clari, P.; Gaillard, C.; Martire, L. \& Reitner, J. 1999. Cold seep deposits of Beauvoisin (Oxfordian; southeastern France) and Marmorito (Miocene; northern Italy): microbially induced, authigenic carbonates. International Journal of Earth Sciences 88: 60-75.

Perry, C. T. \& Taylor, K. G. 2006. Inhibition of dissolution within shallow water carbonate sediments: impacts of terrigenous sediment input on syn-depositional carbonate diagenesis. Sedimentology 53: 495-513.

Postgate, J. R. 1984. The sulphate-reducing bacteria. [2nd edition]. X + 208 pp.; Cambridge (Univ. Press).

Warthman, R.; Van Lith, Y.; Vasconcelos, C.; Mckenzie, J. A. \& Karpoff, A. M. 2000. Bacterially induced dolomite precipitation in anoxic culture experiments. Goology 28: 1091-1094.

Wright, D. T. 1999. Benthic microbial communities and dolomite formation in marine and lacustrine environments - a new dolomite model. In: Glenn, C. R. et al. (eds.): Marine Authigenesis from Global to microbial. SEPM Special Publication 66: 7-20.

\section{Microscopy with polysaccharide and protein probes for calcified cold seep biofilms [poster]}

\author{
Christoph Wrede ${ }^{1}$, Christina Heller ${ }^{2}$, Joachim Reitner ${ }^{2} \&$ Michael Hoppert $^{1}$ \\ ${ }^{1}$ Institut für Mikrobiologie und Genetik, Universität Göttingen, Göttingen, Germany; E-mail: \\ cwrede@gwdg.de_o mhopper@gwdg.de \\ ${ }^{2}$ Geowissenschaftliches Zentrum, Universität Göttingen, Abt. Geobiologie, Göttingen, Germany; E-mail: \\ cheller@gwdg.de_ojreitne@gwdg.de
}

In several fields of cell biology, correlative microscopy is applied to compare the structure of objects at high resolution under the electron microscope with low resolution light microscopy images of the same sample. It is, however, difficult to use samples and specific markers for both microscopic techniques at the same time. In our studies we used mats from cold seep "microbial reefs", located in the black sea shelf (Hinrichs et al. 1999; Blumenberg et al. 2004; Reitner et al. 2005). The mats consist of bacterial and archaeal microorganisms, coupling „reverse“ methanogenesis with the reduction of sulfate. The reverse methanogenic pathway also generates carbonates that precipitate inside the mat and may be the main reason for the formation of a microbial „reef“. The mat shows highly differrentiated aggregates of the various organisms, tightly interconnected by exopolysaccharides (EPS). Our study aimed at the localization of either proteins or extracellular polysaccharides inside the calcifying biofilm. For this purpose, we embedded samples in a hydrophilic resin (Lowicryl K4M). Sections were suitable for 
light as well as electron microscopy in combination with lectins (as polysaccharidespecific probe) and antibodies (as protein-specific probe), either labeled with a fluorescent marker or with colloidal gold (Heller et al. 2008; Wrede et al. 2008). With this method, the distribution of (reverse) methanogenic archaea and biofilm exopolysaccharides could be shown at light and electron microscopy resolution levels. The archaea are concentrated predominantly in globular microcolonies, often, but not always, in symbiotic conjunction with sulfate-reducing bacteria. These distribution patterns are caused by fluxes of substrates and metabolites and give rise to biomineralisate formation inside the structured biofilm.

\title{
References
}

Hinrichs, K.-U.; Hayes, J. M.; Sylva, S. P.; Brewer, P. G. \& DeLong, E. F. 1999. Methane-consuming archaebacteria in marine sediments. Nature 398: 802-805.

Blumenberg, M.; Seifert, R.; Reitner, J.; Pape, T. \& Michaelis, W. 2004. Membrane lipid patterns typify distinct anaerobic methanotrophic consortia. Proceedings of the National Academy of Sciences of the USA 101: 11111-11116.

Reitner, J.; Peckmann, J.; Reimer, A.; Schumann, G. \& Thiel, V. 2005. Methane-derived carbonate build-ups and associated microbial communities at cold seeps on the lower Crimean shelf (Black Sea). Facies 51: 66-79.

Heller, C.; Hoppert, M. \& Reitner, J. 2008. Immunological localization of coenzyme M reductase in anaerobic methane-oxidizing archaea of ANME 1 and ANME 2 type. Geomicrobiology Journal 25: 149-156.

Wrede, C.; Heller, C.; Reitner, J. \& Hoppert, M. 2008. Correlative light/electron microscopy for the investigation of microbial mats from Black Sea Cold Seeps. Journal of Microbiological Methods 73: 8591.

\section{Oncoidal limestone from the Lower Cambrian of South China [poster]}

\author{
Xingliang Zhang \\ Department of Geology and State Key Laboratory for Continental Dynamics, Northwest University, \\ Xi'an, PR China; E-mail: xzhang69@nwu.edu.cn
}

The succession of the Lower Cambrian in the South China Plate demonstrates a wide range of lithofacies; the west margin is elevated to form paleoislands; the plate interior, i. e. the vast area in the west is dominated by siliciclastic platform, with carbonate platform existing in minor areas; down to the east, a wide northeast extended stripe is a shale-dominated slope basin. Oncoidal limestone (oncolite) described herein is from the carbonate platform sequence in the northern margin of the South China plate, presently at the Chaohu area, Anhui Province. The Lower Cambrian here is represented by grain-dominated carbonates, the Mufushan Formation, total thickness about $85 \mathrm{~m}$. A well defined oncolite bed, dark redish in color and about $50 \mathrm{~cm}$ in thickness, occurs in the middle part of the Mufushan Formation. The oncolite bed is underlain by clastic dolostones and overlain by 
oolitic limestones. Oncoids with round and smooth surface, are dark in color, subspherical in shape and desely packed (grain-to-grain contacts), and their size is ranging betweem $3-15 \mathrm{~mm}$ in diameter. The matrix is composed of microspar and fine-bioclasts. Most oncoids show laminated microfabrics without visible filaments, and therefore, they can be decribed as spongiostromate oncoids. Minorites that consist of micrite, exhibit neither distinct lamination nor filamentous structures but are comparable in shape to the laminated type, are recognized as micrite oncoids. The basic lamination of each oncoid consists of couplets seen as dark, organic-rich micritic laminae, alternating with ligther colored laminae poor in organic matter. Laminae are are either concentrically stacked spheroidal layers or randomly arranged, non-continuous and overlapping hemispheroidal layers, which indicate concentric and radial growth patterns, respectively. This oncolite bed intercalated in platform sequences probably marks the base of a transgressive phase. Subspherical shape, well-laminated cortices and radial growth pattern indicate that oncoids form under conditions of regular and frequent overturn. Cooccurrence of different oncoid types and growth patterns is indicative of redeposition.

\section{Sulphur and carbonate microbialites in sulphate-rich Messinian strata, Sicily [talk]}

Simone Ziegenbalg ${ }^{1}$, Daniel Birgel ${ }^{1}$, Adrian Immenhauser ${ }^{2}$, Catherine Pierre ${ }^{3}$, Jean Marie Rouchy ${ }^{4} \&$ Jörn Peckmann ${ }^{1}$

${ }^{1}$ AG Geobiologie, Universität Bremen, Fachbereich Geowissenschaften, Bremen, Germany; E-mail: simone.ziegenbalg@uni-bremen.de,dbirgel@uni-bremen.dedopeckmann@rcom-bremen.de

${ }^{2}$ Sedimentologie und Isotopengeologie, Ruhr-Universität Bochum, Institut für Geologie, Mineralogie und Geophysik, Bochum, Germany; E-mail: Adrian.Immenhausen@rubr-uni-bochum.de

${ }^{3}$ Centre National de la Recherche Scientifique (CNRS), Laboratoire d'Oceanographie Dynamique et de Climatologie, Université Pierre et Marie Curie, Paris, France ; E-mail:Catherine.Pierre@loceanipsl.upmc.fr

${ }^{4}$ CNRS, Laboratoire de Géologie, Muséum National d'Histroire Naturelle, Paris, France ; E-mail: roucby@mnbn.fr

Microorganisms are known to influence the precipitation of carbonates and other minerals in different ways. Biogenic carbonate and sulphur deposits are locally present in sulphate-rich strata. Examples include salt-domes along the cost of the Gulf of Mexico (Feely \& Kulp 1957), the Polish Carpathian foredeep (Pawlowski et al. 1979), or Zechstein strata of Germany (Peckmann et al. 1999). Sulphate-reducing bacteria like Desulfovibrio species use dissolved gypsum to oxidize organic matter, particularly crude oil and short-chain hydrocarbons. Subsequently, the produced 
bicarbonate causes carbonate precipitation and hydrogen sulphide may be oxidized to native sulphur. Although this is known for decades, the timing and processes involved in authigenesis, particularly the mechanism of the oxidation of hydrogen sulphide to sulphur, are not fully understood.

Here, we present new data on microbial carbonate and sulphur deposits from five former sulphur mines of Sicily. The sampled rocks can crudely be divided into four groups: (1) sulphur bearing micrite to microspar crosscut by spar-filled veins associated with secondary sulphates, (2) peloidal limestone cross cut by spar and sulphur filled veins. (3) celestine and gypsum associated with sparry calcite and sulphur, accompanied by minor micrite, and (4) gypsum and anhydrite with sulphur and few small dolomite nodules. Rocks of the first and second group contain accessory sparry calcite representing pseudomorphs after lenticular gypsum crystals, revealing that deposition occurred under evaporative conditions. Carbon isotope values of distinct carbonate mineral phases confirm that carbon is derived from the microbial remineralisation of hydrocarbons. However, the carbon source of secondary carbonates differs among the five mines. The importance of bacterial sulphate reduction is corroborated by low $\delta^{34} \mathrm{~S}$ values of native sulphur and high $\delta^{34} \mathrm{~S}$ values of residual sulphates.

\title{
References
}

Feely, H. W. \& Kulp, J. L. 1957. Origin of gulf coast salt-dome sulfur deposits. Bulletin of the American Association of Petroleum Geologists 41: 1802-1853.

Pawlowski, S.; Pawlowska, K. \& Kubica, B. 1979. Geology and Genesis of Polish Sulfur Deposits. Economic Geology 74: 475-483.

Peckmann, J.; Paul, J. \& Thiel, V. 1999. Bacterially mediated formation of diagenetic aragonite and native sulfur in Zechstein carbonates (Upper Permian, Central Germany). Sedimentary Geology 126: 205-222.

\section{Laser Scanning Microscopy of cellular, polymeric and inorganic constituents in tufa-forming biofilms from two German hardwater creeks [talk]}

Barbara Zippel ${ }^{1} \&$ Thomas. R. Neu ${ }^{1}$

\author{
${ }^{1}$ Helmboltz Centre for Environmental Research - UFZ, Department of River Ecology, Magdeburg, \\ Germany; E-mail: barbara.zippe@@ufz:de \&s thomas.neu@ufz.de
}

Microorganisms are the key players in the formation of microbial carbonates (Riding 2000). Catabolic processes (photosynthesis, denitrification, sulphate reduction and methanogenesis) and the production of extracellular polymeric substances (EPS) may change the physicochemical conditions at interfaces and thereby influence precipitation as well as dissolution of carbonates (Dupraz \& Visscher 
2005). The aim of the presented study is to analyse the in situ structure of tufaforming biofilms by employing Laser Scanning microscopy (LSM). The uppermost layers of tufa-forming biofilms in both hardwater creeks investigated were clearly dominated by filamentous cyanobacteria. A large variety of bacterial morphotypes was detectable by LSM. Single cells of filamentous, coccoid as well as rod-shaped bacteria colonized either the diffuse EPS matrix or discrete EPS structures like the empty sheaths of filamentous cyanobacteria. Furthermore, different bacterial morphotypes were detected within network-like EPS structures. On the other hand, dense bacterial colonization was observed as clusters which completely covered an EPS structure or which built more or less connected strands on top of the diffuse EPS matrix. Furthermore, very dense clusters of small coccoid bacteria were detected at some locations within tufa-forming biofilms. In most cases, the colonies were built of approximately 30-80 cells and had an ellipsoid shape. EPS glycoconjugates were detected according to the fluorescent lectin-binding approach (Neu et al. 2001). A comparison of the lectin-specific binding pattern revealed that the EPS matrix of the tufa-forming biofilms investigated could be separated in at least four main structural domains. Lectin-binding analysis allowed the differentiation between glycoconjugates produced by phototrophic and heterotrophic organisms. Furthermore, EPS glycoconjugate networks covered the surface of the cyanobacterial mat. Apart from cell associated EPS glycoconjugates they were present as flat (sheet-like) structures or as diffuse (cloud-like) EPS matrix. Surprisingly, despite the different hydrochemical composition in terms of relevant nutrients $(\mathrm{P}, \mathrm{N})$ in the creek water, the lectins investigated showed in most cases the same binding pattern in tufa-forming biofilms from both locations. This implies that independent of the trophic status of the habitats the dominant EPS structures consisted more or less of the same glycoconjugates. Finally, calcium carbonate within tufa-forming biofilms from both creeks was determined after staining with Calcein like described by (Moran 2000). Depending on the scanning position calcium carbonate was either observed as more or less densely covered material between cyanobacterial filaments and diatoms or as encrustations of single filamentous cyanobacteria. In almost all cases, some empty holes within densely calcium carbonate structures were detectable. Due to the morphology it seems reasonable, that those structures are formed by filamentous cyanobacteria. In order to get detailed information about relationships between calcium carbonate and different structural EPS domains determined by fluorescent lectin-binding analysis both staining techniques were combined. Again, calcium carbonate structures were detected either around living filamentous cyanobacteria or as closely associated with empty sheaths and the diffuse EPS matrix. In some cases, co-localization of calcium carbonate and fine EPS structures was observable which means that both constituents are very closely associated. It could be shown that co-localization signals in the two channels was neither caused by artefacts due crosstalk of the stains used nor by background artefacts.

In summary, it can be concluded that by this approach it is possible to differentiate between EPS glycoconjugates which are related to various biofilm organisms and 
possibly others which are more closely connected to calcium carbonate structures and those which are maybe the framework macromolecules as mentioned by (Weiner \& Addahi 1997).

\section{References}

Dupraz, C. \& Visscher, P. T. 2005. Microbial lithification in marine stromatolites and hypersaline mats. Trends in Microbiology 13: 429-438.

Moran, A. L. 2000. Calcein as a marker in experimental studies newly-hatched gastropods. Marine Biology 137: 893-898.

Neu, T. R.; Swerhone, G. D. W. \& Lawrence, J. R. 2001. Assessment of lectin-binding analysis for in situ detection of glycoconjugates in biofilm systems. Microbiology 147: 299-313.

Riding, R. 2000. Microbial carbonates: the geological record of calcified bacterial-algal mats and biofilms. Sedimentology 47: 179-214.

Weiner, S. \& Addahi, L. 1997. Design strategies in mineralized biological materials. Journal of Materials Chemistry 7: 689-702.

\section{The role of microbial biofilms in mineral formation of tufa systems - combination of Laser Scanning Microscopy and Scanning Trans- mission X-ray Microscopy (STXM) [poster]}

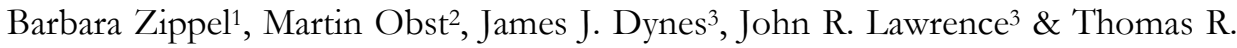
$\mathrm{Neu}^{1}$

${ }^{1}$ Helmboltz Centre for Environmental Research - UFZ, Department of River Ecology, Magdeburg,

Germany; E-mail: barbara.zippel@ufz.de ๘ thomas.nen@ufz.de

${ }^{2}$ CLS Canadian Light Source Inc., University of Saskatchewan, Saskatoon, SK, Canada; E-mail: martin.obst@lightsource.ca

${ }^{3}$ Environment Canada, Saskatoon, SK, Canada; E-mail:john.lawrence@ec.gc.ca \& james.dynes@ec.gc.ca

Biofilm systems represent an important way of microbiological life. In this project we study environmental biofilms which are involved in mineral formation. Tufa deposits in freshwater habitats are the result of lithification processes within interfacial microbial ecosystems. Calcite precipitation is influenced by the saturation index and the occurrence of extracellular polymeric substances (EPS) which are produced by a variety by microorganisms (Dupraz \& Visscher 2005). EPS may function as a chelator for cations and a template for crystal nucleation. In the present study we take advantage of Laser scanning Microscopy (LSM) and combine it with Synchrotron imaging using Scanning Transmission X-ray Microscopy (STXM). By means of STXM it was possible to differentiate between calcite, aragonite and vaterite at the Ca L-edge (Benzerara et al. 2004). STXM has also been used at the $\mathrm{C} \mathrm{K}$-edge to map the major biomolecules (protein, lipids, and 
polysaccharides) (Benzerara et al. 2006; Lawrence et al. 2006). STXM represents a technique that allows simultaneous analysis of inorganic and organic constituents at a scale of $50 \mathrm{~nm}$ (Dynes et al. 2006; Hitchock et al. 2005). A key aspect of this study is that we can examine identical areas of a biofilm by both scanning X-ray transmission and confocal laser scanning microscopy (Lawrence et al. 2003). The goal is to elucidate the potential of biofilm constituents, including microbial cell surfaces and extracellular polymeric substances (EPS), in triggering the formation of calcium carbonate formation in tufa systems. In order to prove the feasibility of the STXM method, major biomolecules and different calcium carbonate phases were detected on freshly sampled tufa-forming biofilms from Westerhöfer Bach (Harz Mountains, Germany) as well as in calcifying biofilm grown in a laboratory incubator. Near-edge X-ray absorption fine structure (NEXAFS) spectra were recorded at the carbon K-edge $(280-320 \mathrm{eV}$ ) and the calcium L-edge (342$360 \mathrm{eV}$ ). Data analysis was done by using the software aXis 2000 . It could be deduced from the energy spectra that the samples were at least partly covered with dense calcium carbonate structures. Fitting procedures with available reference spectra (aragonite, calcite, and calcium absorbed to EPS) revealed the occurrence of different calcium carbonate phases. With this combined approach it is possible to analyse inorganic compounds (elements) as well as organic compounds (EPS) within the complex biofilm matrix. The results will aim to contribute to the understanding of mineralisation processes controlled by microorganisms.

\section{References}

Benzerara, K.; Menguy, N.; Lopez-Garcia, P.; Yoon, T.-H.; Kazmierczak, J.; Tyliszczack, T.; Guyot, F.; Brown, G. E. [jr.] 2006. Nanoscale detection of organic signatures in carbonate microbialites. Proceedings of the National Academy of Sciences of the USA 103 (25): 9440-9445.

Benzerara, K.; Yoon, T. H.; Tyliszczak, T.; Constantz, B.; Spormann, A. M. \& Brown, G. E. [jr.] 2004. Scanning transmission x-ray microscopy study of microbial calcification. Geobiology 2: 249259.

Dupraz, C. \& Visscher, P. T. 2005. Microbial lithification in marine stromatolites and hypersaline mats. Trends in Microbiology 13: 429-438.

Dynes, J.J.; Tyliszczak, T.; Araki, T.; Lawrence, J. R.; Swerhone, G. D. W.; Leppard, G. G. \& Hitchcock, A. P. 2006. Speciation and quantitative mapping of metal species in microbial biofilms using scanning transmission X-ray microscopy. Environmental Science \& Technology 40: 1556-1565.

Hitchcock, A. P.; Morin, C.; Zhang, X.; Araki, T.; Dynes, J. J.; Stöver, H.; Brash, J.; Lawrence, J. R. \& Leppard, G. G. 2005. Soft X-ray spectromicroscopy of biological and synthetic polymer systems. Journal of Electron Spectroscopy and Related Phenomena 144-147: 259-269.

Lawrence, J. R.; Swerhone, G. D. W.; Leppard, G. G.; Araki, T.; Zhang, X.; West, M. M. \& Hitchcock, A. P. 2003. Scanning transmission x-ray, laser scanning, and transmission electron microscopy mapping of the exopolymeric matrix of microbial biofilms. Applied and Environmental Microbiology 69: 5543-5554. 


\title{
Do calcium-sensitive dyes bind to specific proteins within the EPS of tufa-forming biofilms? - Implication for Fluorescence Lifetime Imaging (FLIM) [poster]
}

\author{
Barbara Zippel ${ }^{1}$, Ute Kuhlicke' $\&$ Thomas. R. Neu ${ }^{1}$ \\ ${ }^{1}$ Helmboltz Centre for Environmental Research - UFZ, Department of River Ecology, Magdeburg, \\ Germany; E-mail:barbara.zippel@ufz.de,ute.kublicke@ufz.de@thomas.neu@ufz.de
}

In studies of biological induced mineralisation processes one hypothesis highlighted, is that binding of calcium ions to functional, negatively charged groups of extracellular polymeric substances (EPS) produced by cyanobacteria prevents calcite precipitation in stromatolite- and tufa-forming biofilms (Dupraz \& Visscher 2005). In the study presented the focus is on the structural analysis of EPS matrix of tufa-forming biofilms in two German hardwater creeks (Westerhöfer Bach, Deinschwanger Bach) by means of Laser Scanning Microscopy. EPS glycoconjugates were detected according to the fluorescence lectin-binding approach as described elsewhere (Neu et al. 2001). The application of different calcium-sensitive stains (Molecular Probes) revealed that in case of CalciumGreen-1 and BAPTA OregonGreen-1 a lot of clear signals were detectable near the cell surface or as part of the closely bound EPS fraction around filamentous cyanobacteria. Normally, these Calcium-sensitive dyes are used for Ca-imaging inside living cells in combination with fluorescence lifetime imaging - FLIM (Wilms \& Eilers 2007). In that case a double-exponential lifetime analysis allows the quantification of $\mathrm{Ca}$ free and Ca-bound dye fractions. Briefly, the lifetime $(\tau)$ of $\mathrm{Ca}$-free dye lies in the range of 350-390 ps and increases substantially to longer lifetime (2.5-3.6 ns) if the dye is bound to calcium (Wilms et al. 2006). The binding of calcium-sensitive stains to $\mathrm{Ca}^{2+}$-ions in the original creek water resulted in long fluorescence lifetimes as expected from the literature. Surprisingly, short lifetimes in combination with high intensities were detected in the envelope of filamentous cyanobacteria living within the tufa-forming biofilms. This implies at least some important questions: (1) Is the observation of short lifetimes and high intensities attributed to dye aggregation or binding of the dyes to proteins as described for multiphoton $\mathrm{pH}$ lifetime imaging (Gerritsen et al. 2006)? (2) Is the switch from Ca-bound stage (in the bulk water) to Ca-free stage (in the envelope) mediated by a releasing of $\mathrm{Ca}^{2+}$-ions from the dye complex caused by high attraction power of other negatevely charged groups available in the EPS matrix? (3) Is binding of the dye to specific proteins/peptides mediated by $\mathrm{Ca}^{2+}$ - or other ions as described in (Hauser $\&$ Tsien 2007)?

Beside of all these speculative questions, observations made by the FLIM approach would have interesting implications for the detection of specific ion-binding proteins within the EPS matrix of calcifying biofilms in various habitats (ocean, hypersaline lakes and freshwater systems). 


\title{
References
}

Dupraz, C. \& Visscher, P. T. 2005. Microbial lithification in marine stromatolites and hypersaline mats. Trends in Microbiology 13: 429-438.

Gerritsen, H. C.; Draaijer, A.; Heuvel, D. J. van den \& Agronskaia, A. V. 2006. Fluorescence Lifetime Imaging in Scanning Microscopy. In: Pawley, J. B. (ed.): Handbook of Biological Confocal Microscopy. [3 $3^{\text {rd }}$ ed.] pp. 516-533; New York (Plenum Press).

Hauser, C. T. \& Tsien, R. Y. 2007. A hexahistidine $\mathrm{Zn}^{2+}$-dye label reveals STIM1 surface exposure. Proceedings of the National Academy of Sciences of the USA 104: 3693-3697.

Neu, T. R.; Swerhone, G. D. W. \& Lawrence, J. R. 2001. Assessment of lectin-binding analysis for in situ detection of glycoconjugates in biofilm systems. Microbiology 147: 299-313.

Wilms, C. \& Eilers, J. 2007. Photo-physical properties of $\mathrm{Ca}^{2+}$-indicator dyes suitable for two-photon fluorescence-lifetime recordings. Journal of Microscopy 225 (3): 209-213.

Wilms, C. D.; Schmidt, H. \& Eilers, J. 2006. Quantitative two-photon $\mathrm{Ca}^{2+}$ imaging via fluorescence lifetime analysis. Cell Calcium 40: 73-79.

\section{Application of Laser Raman Spectroscopy to early life studies: Carbonaceous matter in a $>3.8$ Ga quartz-rich rock on Akilia Island, southern West Greenland [talk]}

\author{
Mark van Zuilen ${ }^{1}$, Aivo Lepland ${ }^{2} \&$ Pascal Philippot $^{1}$ \\ ${ }^{1}$ Institut de Physique du Globe de Paris, Paris, France; E-mail: vanzuilen@ipgp.jussieu.fr \& \\ philippot@ipgp.jussieu.fr \\ ${ }^{2}$ Geological Survey of Norway, Trondheim, Norway; E-mail: aivo.lepland@ngu.no
}

The record of biosignatures in Early Archean rocks has often been found to be ambiguous because of severe metamorphic overprint. Deformation has modified the original morphology of microfossil structures and thermal degradation has turned organic compounds (including molecular biomarkers) into kerogen or graphite. In addition, certain abiologic hydrothermal/metasomatic reactions could have produced organic compounds or graphite. Macroscopic fossil evidence in the form of stromatolites has been controversial as well, since several abiologic processes - such as soft-sediment deformation, evaporite deposition, hot spring sinter formation - were identified that resulted in similar degrees of structural complexity. The combination of these issues has made the search for traces of early life in highly metamorphosed terrains a great challenge, and has led to several ongoing controversies.

In order to overcome the multitude of problems associated with metamorphic overprint in Archean terrains there is a strong need for careful description of geological context, identification of secondary metamorphic and hydrothermal processes, and detailed structural, isotopic and chemical description of microstructures that are indigenous to and syngenetic with the rock formations. An 
important improvement in this field of research is the wide variety of new isotopic and chemical techniques that can be applied to small rock samples. Laser Raman Spectroscopy (LRS) is now used routinely for non-destructive identification and 2D-mapping of organic microfossils, the identification and exclusion of artefacts and post-metamorphic organic contamination, and rapid identification of different mineral phases within stromatolites. Here we discuss the validity of the oldest putative traces of life on Earth, using LRS. This study shows how LRS is a necessary analytical technique that should be used in combination with routine petrographic description of Archean rock thinsections before other detailed in-situ analytical techniques are applied (such as SIMS, NanoSIMS, TEM).

A highly metamorphosed quartz-rich rock on the southwestern tip of Akilia Island (West Greenland) has for long been the center of attention regarding the oldest traces of life on Earth. This five meter wide outcrop was interpreted as a $>3.8 \mathrm{Ga}$ banded iron formation and was found to contain graphite inclusions within apatite crystals. The low $\delta^{13} \mathrm{C}$ of these graphite inclusions suggested a biologic source material that had retained its original carbon isotope signature. Our search for carbonaceous matter in Akilia samples using Raman spectroscopy has revealed the presence of thin, submicron-scale films of carbonaceous matter that occur at crystal interfaces, but most commonly wrap around magnetite crystals. Typical Raman spectra from these films mostly have characteristics of disordered graphite. Carbonaceous films have a limited spatial distribution, and are usually found in association with fine-grained magnetite occurring as lamellae in amphibole (grunerite, actinolite). Mineral assemblages and metamorphic textures demonstrate that the amphibole-lamellar magnetite-carbonaceous matter assemblage replaces pyroxene-calcite during retrogression. Typical occurrence of carbonaceous matter in retrogressive mineral assemblages suggests its epigenetic origin from a $\mathrm{CO}_{2}$ source that was ultimately derived from carbonate break down. Another more graphitic form of carbonaceous matter occurs together with $\mathrm{H}_{2} \mathrm{O}, \mathrm{CO}_{2}$ and $\mathrm{CH}_{4}$ in secondary fluid inclusion trails in quartz crystals. Thermodynamic constraints in the $\mathrm{COH}$-system indicate that the graphite formed by dehydration reactions, partial leakage of inclusion fluids, or mixing of $\mathrm{CO}_{2}$ and $\mathrm{CH}_{4}$. These abiologic explanations cannot be excluded and therefore the use of carbonaceous matter in Akilia samples as a tracer for ancient life is ambiguous. 


\title{
Excursion A:
}

\section{Pre-Conference Field Trip}

\author{
Kalkowsky's type stromatolites and other microbialites \\ of Lower Saxony \\ Josef Paul ${ }^{1}$, Gernot Arp ${ }^{2} \&$ Joachim Reitner ${ }^{2}$ \\ ${ }^{1}$ Geowissenschaftliches Zentrum, Georg-August-Universität Göttingen, Abt. Sediment/Umweltgeologie, \\ Göttingen, Germany; E-mail:jpaul@gwdg.de \\ ${ }^{2}$ Geowissenschaftliches Zentrum, Georg-August-Universität Göttingen, Abt. Geobiologie, Göttingen, \\ Germany; E-mail: garp@gwdg.de \&ojreitne@gwdg.de
}

\section{Introduction}

Although microbialites, i. e., sedimentary rocks built by benthic microbial communities (Burne \& Moore 1987), commonly form only a small volume of geological formations, they are conspicuous and palaeoenvironmentally significant intercalations in sedimentary successions; Indeed, microbial rocks with macroscopic lamination, that have been quarried as building stones from the Lower Triassic Buntsandstein Group around the Harz Mountains, have already been investigated in detail by Kalkowsky in 1908, thereby coining the term "Stromatolith" (stromatolite). One of the outcrops showing these $245 \mathrm{Ma}$ old saline-lacustrine stromatolites, meanwhile protected as a geological monument, will be visited during this field trip (Stop 1: Heeseberg). Because microbialite formation reflects microbial activity in relation to external chemical and physical parameter, microbialites form a valuable source of information for the reconstruction of palaeoenvironments and long-term evolution of seawater chemistry.

In central Germany, a wide range of fossil microbialites have been discovered since the initial description of the type stromatolites in the Lower Triassic lacustrine deposits. These include marine-hypersaline stromatolites and thrombolites (Upper Permian Zechstein Group: Stop 2; Tithonian Münder Formation: Stop 3), freshwater to saline-lacustrine stromatolites (Norian part of Keuper Group; Arp et al. 2005), marine non-cyanobacterial stromatolites of the Schwarzjura Group (Arp et al. 2004), marine reefal microbialite crusts (Oxfordian Reefs of the "Korallenoolith"; Helm \& Schülke 1998, Betzler et al. 2006), freshwater oncoids (Berriasian "Purbeck" deposits; Dragastan \& Richter 2001, Arp \& Mennerich 2008), and, 
relatively recently discovered (Peckmann et al. 2001), deeper-marine seep carbonates of the Lower Carboniferous (Stop 4: Iberg) (Table 1). Present-day forming microbialites are restricted to tufa stromatolites of karst-water creeks (e. g., Westerhöfer Creek; Shiraishi et al. 2008a, 2008b), discharging from aquifers largely of Mesozoic limestone formations.

The general geological setting in this central part of Germany is characterized by a division into a folded Silurian-Carboniferous basement ("Variscian") with local Lower Permian intramontane molasse sediments and volcanics, a thick Upper Permian evaporite succession, and an up to $3 \mathrm{~km}$ thick Mesozoic cover composed of alternating marine and non-marine sediments. The Variscian basement was formed by the Late Paleozoic collision of microcontinents (terranes) and their accretionary wedges between Gondwana and Laurussia (Franke 1999). This collision is part of the formation of the supercontinent Pangaea.

The Devonian succession of the Variscian basement, exposed in the Harz Mountains (Fig. 1), was deposited on a thinned continental crust with a narrow zone of oceanic crust to the south. This Rheno-Hercynian Ocean originated from crustal extension, possibly reflecting back-arc extension related to a subduction zone farther south. In general, shallow-marine clastics are successively replaced by deeper-marine shales and cherts. Submarine volcanic swells form the basis of Givetian-Frasnian atoll reefs, largely composed of stromatoporoids, rugose and tabulate corals (e. g., Franke 1973, Gischler 1992).

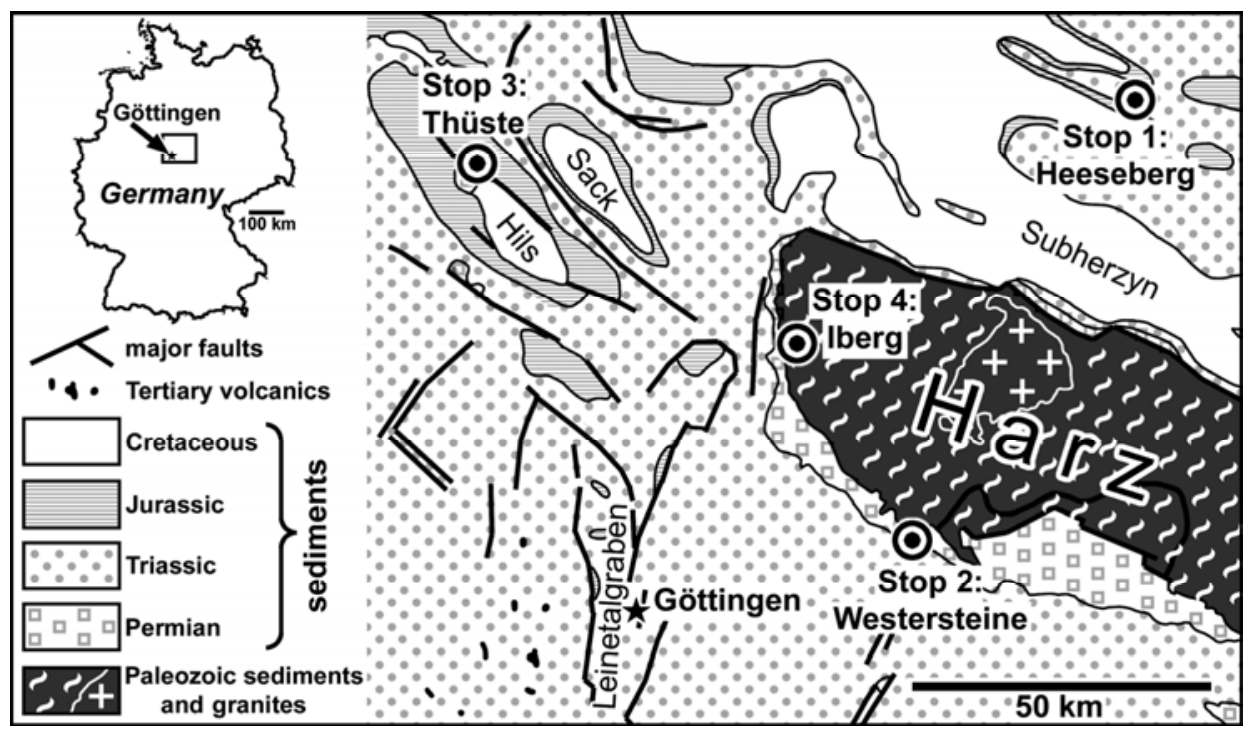

Fig. 1. Simplified geological map of the pre-symposium field trip area with location of the stops. 
From Frasnian times onwards, the change to a convergent tectonic regime caused southward subduction of this ocean along a complex island arc (Mid-German Crystalline High), where underplating of pre-Devonian basement from Upper Tournaisian onwards followed (Franke 1999).

In the northern foreland, i. e. Rhenohercynian zone, synorogenic clastic sediments (Flysch greywackes) of considerable thickness, derived from the Mid-German Crystalline High, successively overstepped the deep-marine shales, cherts, drowning reef complexes and seamounts (Stop 4).

\begin{tabular}{|c|c|}
\hline Chronos & igraphy \\
\hline \multicolumn{2}{|l|}{ Quaternary } \\
\hline \multicolumn{2}{|l|}{ Tertiary } \\
\hline$-65 \mathrm{ma}$ & \\
\hline Cretaceous & $\begin{array}{l}\text { Upper } \\
\text { Lower }\end{array}$ \\
\hline Jurassic & $\begin{array}{l}\text { ¿ Tithonian } \\
\text { ڤ Kimmeridgian } \\
\text { S Oxfordian } \\
\text { Middle } \\
\text { Lower }\end{array}$ \\
\hline-2 & 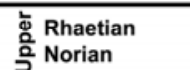 \\
\hline Triassic & 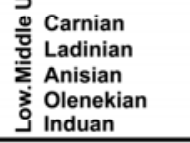 \\
\hline & 을 Lopingian \\
\hline Permian & $\begin{array}{l}\text { Guadalupian } \\
\text { Cisuralian }\end{array}$ \\
\hline$-296 \mathrm{ma}$ & Upper \\
\hline Carboniferous & $\begin{array}{l}\text { Serpukhovian } \\
\text { בे Visean } \\
\text { త Tournaisian }\end{array}$ \\
\hline$-358 \mathrm{ma}$ & $\begin{array}{l}\text { ळ్ Famennian } \\
\text { 을 Frasnian }\end{array}$ \\
\hline Devonian & $\begin{array}{l}\text { „ूँ Givetian } \\
\text { एँ Eifelian } \\
\text { Lower }\end{array}$ \\
\hline
\end{tabular}

\section{Lithostratigraphy}

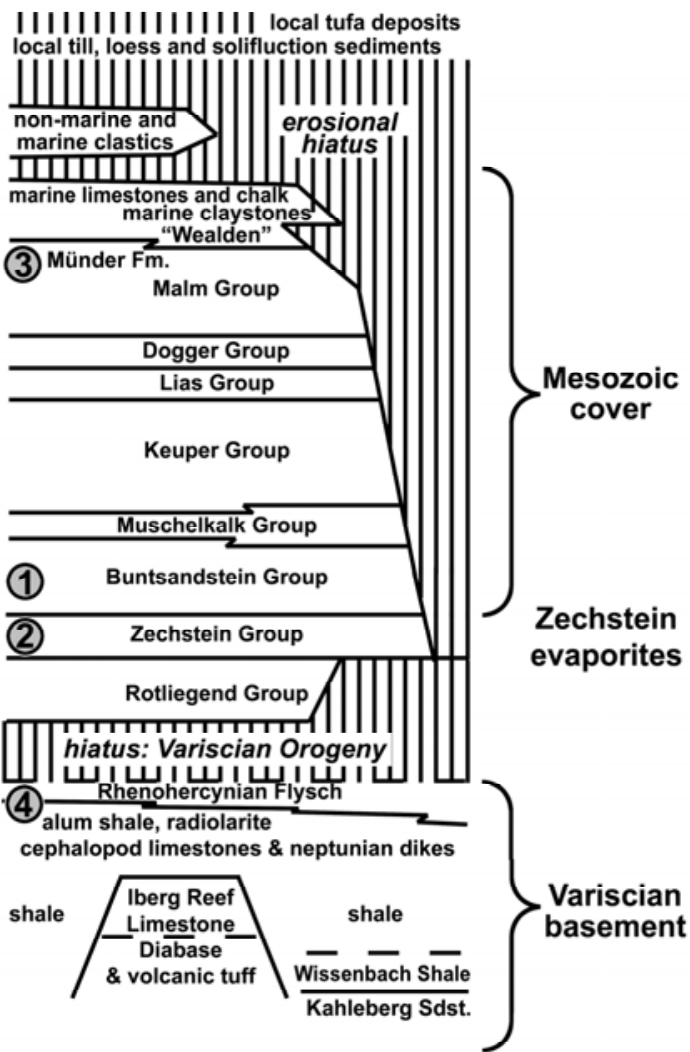

Fig. 2. Stratigraphic overview of the Devonian to Quaternary sedimentary succession of the field trip area. Numbers indicate microbialite occurrences visited during this field trip. Absolute ages and stratigraphic terms according to German Stratigraphic Commission (2002). 
Folding, uplift of the accretionary wedge and magmatic intrusions occurred during the Upper Carboniferous, a time interval represented by a major, angular unconformity in the field trip area. A change to dextral tectonic tension during postorogenic times resulted in strike-slip-fault graben structures, which accommodate Upper Carboniferous-Lower Permian molasse sediments of the Rotliegend Group. This terrestrial to lacustrine red bed sedimentation was accompanied by an intensive, bimodal volcanism.

After erosion of the Variscian fold belt, crustal cooling and thermal subsidence caused formation of the epicontinental Germanic Basin, which controlled sedimentation from Late Permian to Late Triassic times. First marine ingressions from the Arctic though a narrow seaway to resulted in seven marine evaporite cycles of the Zechstein Group (Lopingian), which is in total 300 to $1500 \mathrm{~m}$ thick. Especially the first, "deep-shelf" cycles are carbonate-sulphate-halite-successions, with economically important potassium salt on their top. Within the latest Permian, sedimenttation changed to non-marine, with extensive fluvial systems draining into a central playa lake (e. g., Paul 1982, 1999). These red bed sediments, with maximum thicknesses of more than $1000 \mathrm{~m}$ in the basin centre, are summarized as Buntsandstein Group. They roughly represent the Lower Triassic, however, precisely range from latest Lopingian to earliest Anisian times.

Opening of the Germanic Basin to the southeast and rise in sealevel during the deposition of the Upper Buntsandstein Group (Rot Formation) resulted in a further, stepwise flooding of the basin, and finally deposition of the Middle Triassic Muschelkalk Group. The latter is a $200-250 \mathrm{~m}$ thick marine limestonesmarl alternation with an intermediate evaporite succession. The Upper Triassic again shows non-marine red bed sediments, i. e. siliciclastics of rivers draining into a central playa lake, as well as deltaic and evaporitic sediments (Keuper Group, 300-1500 m). Opening of new seaways and uplift in Eastern Europe terminated the time interval of the Germanic Basin (Ziegler 1990).

Open-marine dark clay- and marlstones characterize the Lower and Middle Jurassic in Northern Germany, followed by an Upper Jurassic carbonate ramp of strongly varying thickness. Indeed, opening of the North Atlantic affected the field-trip area at that time by block faulting, mobilization of Zechstein salts, and initiation of diapirism. Due to salt tectonics and sealevel fall, uppermost Jurassic-lowermost Cretaceous deposits are restricted to a narrow Lower Saxony Basin with its evaporative Münder Formation and limnic Bückeburg Formation ("Wealden"). Later, successive increase in eustatic sealevel gave rise to the deposition of Valanginian to Aptian open-marine marlstones followed by chalky limestones of the Cenomanian to Maastrichtian. Tertiary times are characterized by tectonic uplift, last marine ingressions (during Oligocene eustatic highstand), wide-spread erosion and minor magmatic plume activity (Miocene basalts). The present-day surface geomorphology largely reflects extensive erosion under periglacial conditions during the last Pleistocene glaciations. 


\section{Stop 1: Kalkowsky's Stromatolites and Oolites at the Heeseberg Quarries (J. Paul)}

Location: Topographic Map of Lower Saxony Sheet 3931 Jerxheim, east 4421 800, north 5772 800. Disused quarries (Natural monument) at the Heeseberg near Jerxheim, north of the Harz Mts.

Geological Formation: Lower Buntsandstein Group, Bernburg Formation.

Geological Age: Lower Triassic, Induan, ca. 245 Ma.

Description: Three worldwide used geological terms originate from the Lower Triassic rocks of northern Germany. The term "oolite" has been coined 1721 by Brückmann, doctor of medicine and science, at the dawn of science. The words "stromatolite" and "ooid" derived from Kalkowsky (1908), professor of mineralogy at the University of Leipzig. The most interesting paragraphs of the article of Kalkowsky (1908) are translated at the end of this section. Some outcrops described by Kalkowsky (1908) still exist. They are natural monuments like the quarries at the Heeseberg. Aim of this excursion stop is to present the largest outcrop of Kalkowsky's stromatolites and oolites and to work out the environmental conditions which controlled their formation.

The Heeseberg is situated at the eastern end of an elongated Zechstein salt diapir aligned parallel to the northern margin of the Harz Mts. At the top of an elongated hill, there are several disused quarries. Oolites of the Bernburg Fm., Lower Buntsandstein Subgroup, have been quarried. At the Heeseberg, there are the largest ooids $(>1 \mathrm{~cm}$ diameter), the thickest oolite beds $(7 \mathrm{~m})$ and large stromatolite domes $(>1 \mathrm{~m})$ at the surface of the oolite bed. Within the oolite section, there are only smaller stromatolite domes.

The Lower Buntsandstein is of Lower Triassic age (Fig. 3). It was deposited in an closed inland basin stretching from England to Poland and from Denmark to southern Germany (Fig. 4). The sediments are between 300 and $500 \mathrm{~m}$ thick and consist mainly of sandstones at the margins whereas mudstones dominate in the basin centre. Additionally, the centre of the basin is marked by oolitic limestones. The Lower Buntsandstein is divided into two formations, the Calvörde Formation and the Bernburg Formation. The latter is hosting the stromatolites (Fig. 3, 5). Both formations are composed of 11 or 10 cycles, respectively. The 10 and $20 \mathrm{~m}$ thick cycles are climatically controlled Milankovitch Cycles with a period of 0.1 Ma. They can be traced all over the basin and are used as marker horizons. Cycles start with erosive fluvial sandstones due to heavy rains in an normally arid environment. At that time, Central Europe was at a position of about $25^{\circ}$ northern latitude. The sandstones are transported into the basin centre. The above following alternation of sandstones and mudstones is deposited in a more or less permanent lake. The outline of this lake is given by the presence of oolite beds in the sediment (Fig. 4). 


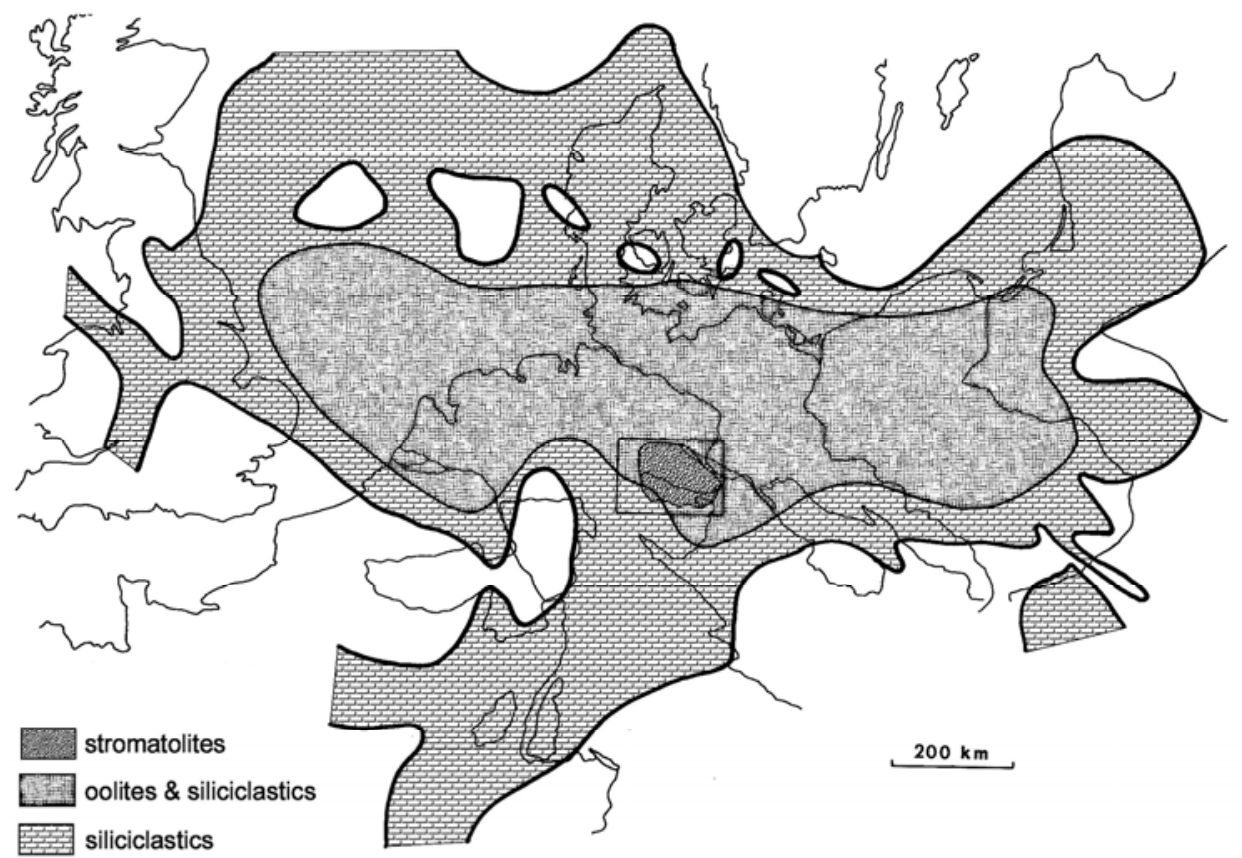

Fig. 3. The Lower Buntsandstein of the Germanic Basin. After Paul (1982).

The upper parts of the cycles are built of mostly structureless mudstones which contain anhydrite nodules as an indication of increased salinity in the pore water. These sediments are deposited in a systeme of playa lakes. The Lower Buntsandstein is nearly free of fossils, body fossils as well as trace fossils. Higher organized life reacts very sensitive against fluctuating salinities in this shallow lake.

The centre of oolites concerning size of the ooids and thickness of the oolite beds is the area north of the Harz Mountains. The occurrence of stromatolites is restrictted to this area, too. Towards the margin of the basin the ooids are smaller and mixed with siliciclastic sandstones. A palaeo-high, the Eichsfeld High, controls the flux of clastic particles into the basin (Fig. 6). This palaeo-high protects the stromatolite area against pollution by sandy and clayey particles (Paul \& Peryt 2000).

The mineralogy of the ooids was investigated by Usdowski (1962). Most ooids have tangentially oriented calcite crystals, a subordinate number have radially orientted crystals. The cortex is built of small grains of quartz, feldspar or biotite. Occasionally, two or more ooids are fused to larger grains, called poly-ooid or ooid-bag by Kalkowsky (1908). The recent mineralogy of the ooids is the result of diagenetic processes. In the outcrop, ooids are well sorted, forming ripples or flat layers. Erosion features are very rare. 


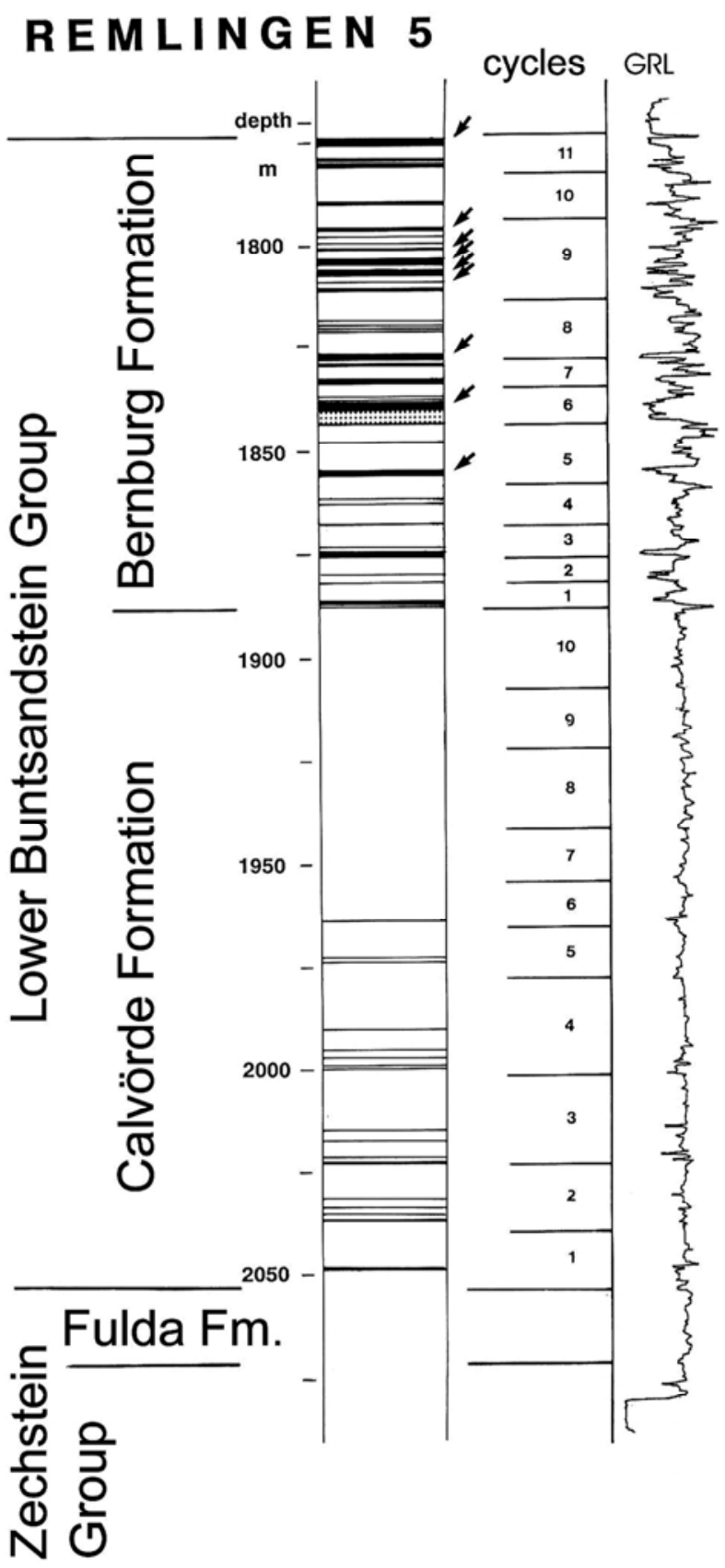

Fig. 4. Stratigraphy of the Lower Buntsandstein. The well Remlingen 5 is about $15 \mathrm{~km}$ away from the Heeseberg. After Paul \& Peryt (2000). 


\section{HEESEBERG Oolithe \& Stromatolithe}

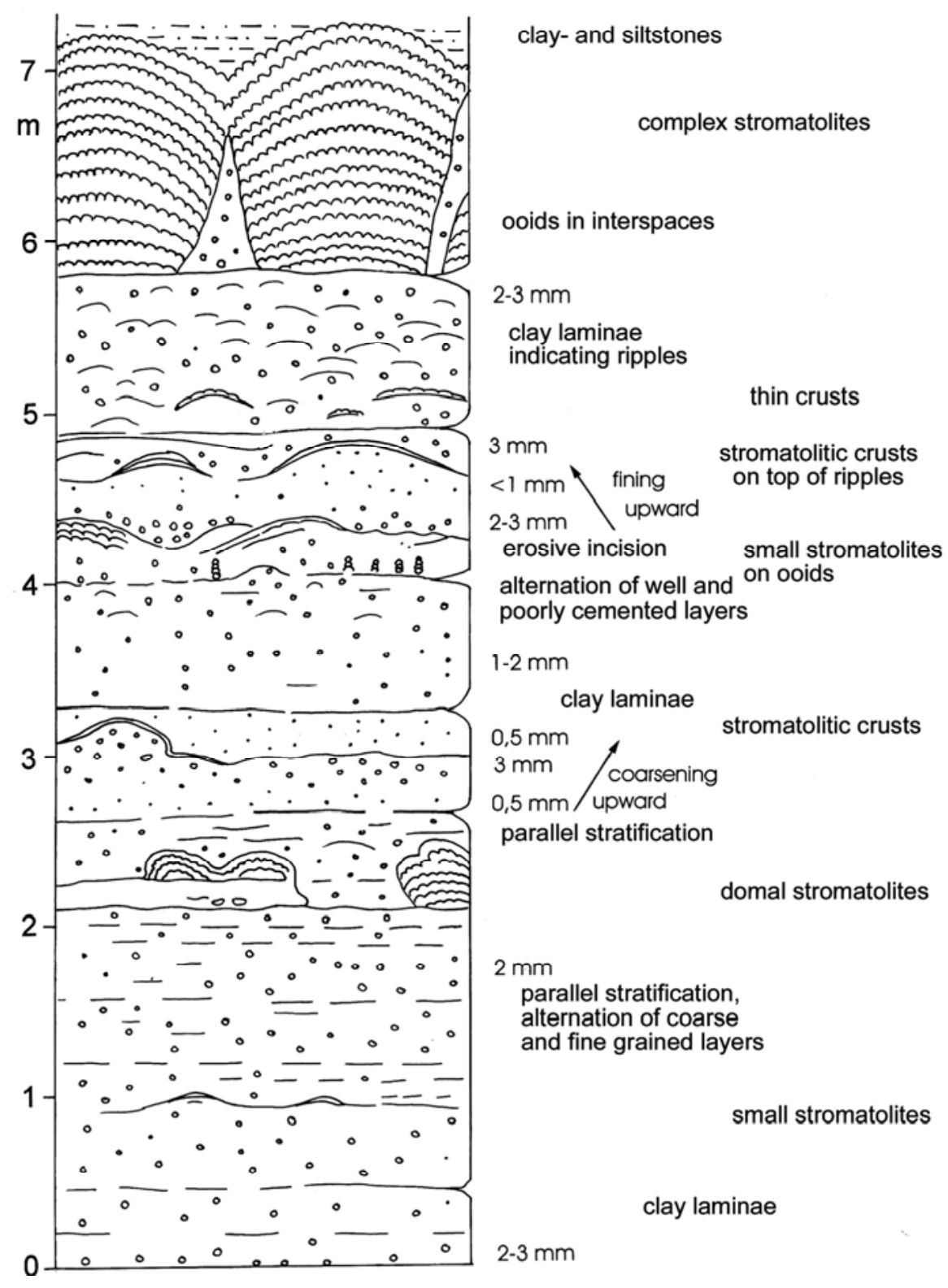

Fig. 5. Section of the oolite bed at the Heeseberg. 


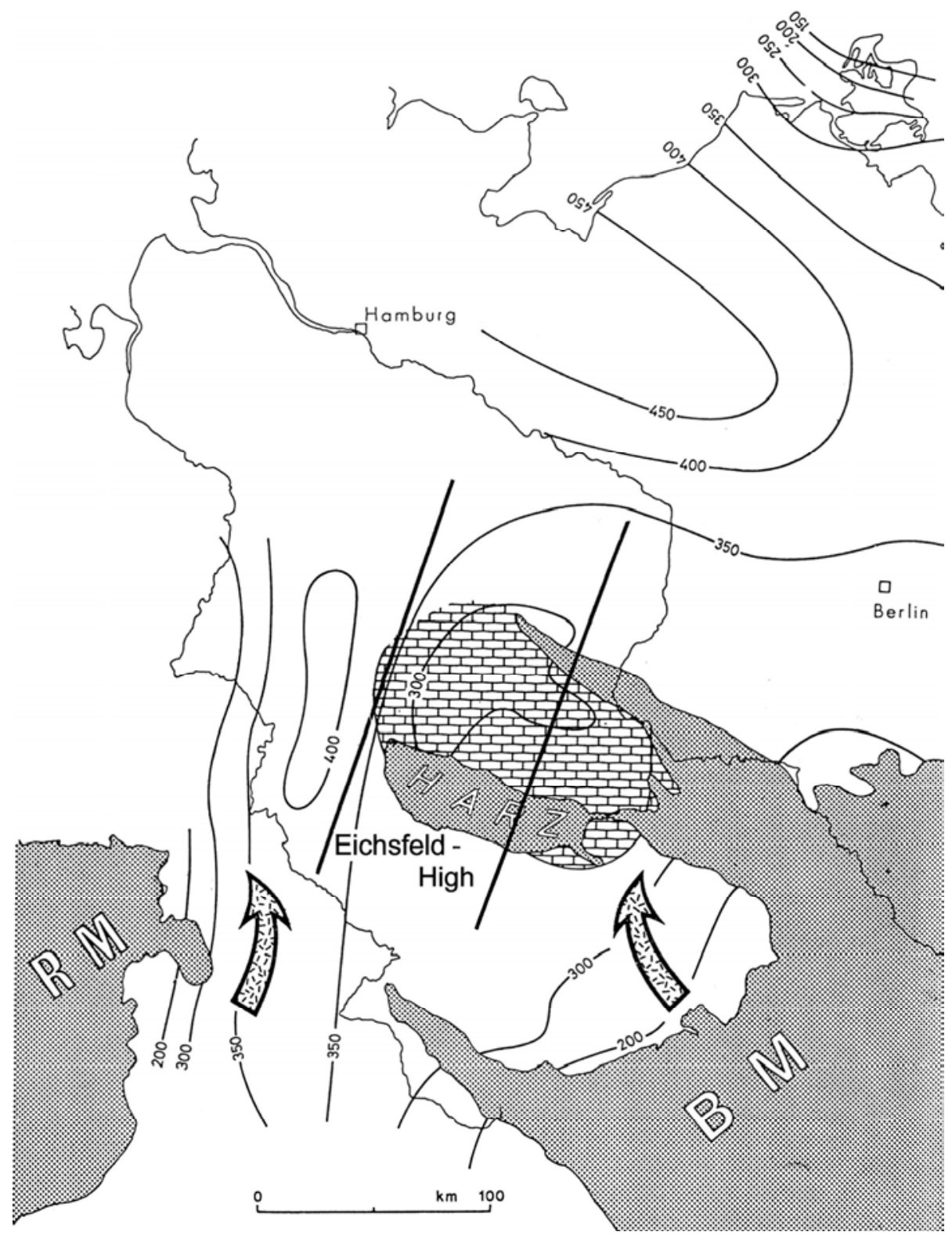

Fig. 6. Palaeogeography of the Eichsfeld High at the Lower Buntsandstein. After Paul \& Peryt (2000).

Stromatolites consist according to the definition given by Kalkowsky (1908) of laminated limestones. They are bound to the oolites, preferentially to the surface of 
oolite beds. The thicker the oolite bed, the higher the probability of stromatolites and the larger the stromatolites. Stromatolites occur in various forms, ranging from thin crusts to isolated two metres high branching domes. Crusts are thicker on top of oolite ripples, wedging out towards flanks and depressions. Occasionally, there are some millimetres high stromatolitic columns above single ooid grain. The larger domal stromatolites are compound structures branching like trees. In the interstice between the domes there are ooids of various size. Most likely, the high of the domes above their surrounding was only some centimetres. The microscopic inspection shows an intensive sparitization, a dominant radially oriented sparitic texture. Two groups of stromatolitic micro-structures can be distinguished: a spongy-fenestrate and a fan-like fabric. Occasionally, the surfaces of stromatolites are dissolved. Most likely due to the microbial decay of organic substances forming acids which dissolved the limestone. There is no direct proof which group of organisms has built these organic-sedimentary structures. But, on behalf of the observed upward directed growth morphologies, cyanobacteria may be the producers.

From medivial times to the early $20^{\text {th }}$ century, the oolites were used as dimension and building stones for sacral and secular buildings. In the 19th century oolite blocks were shipped to the north German harbours for building quays. Since 1972 the Heeseberg is a natural monument, for its geological importance as well as for the interesting flora which contains several steppe species of southeastern Europe which have here their western limit.

Kalkowsky's stromatolites and oolites were formed in a slightly saline or brackish environment on extended bars of a shallow inland lake. This is exactly, what Kalkowsky (1908) described. A possible modern analogue of this setting might be the Great Salt Lake, Utah.

\section{Kalkowsky: „Oolith und Stromatolith im norddeutschen Buntsandstein“ (Oolites and stromatolites in the Bunter Sandstone (Lower Triassic), north Germany) \\ [Translation of selected extracts by J. Paul, Göttingen, and R.V. Burne \& U. Troitzsch, Canberra. Numbers refer to the numbered paragraphs in the original publication]}

Note: Kalkowsky's use of the suffix "-lith - plural -lithe" is translate by the suffix "-lite, plural lites". 
3. The new term "Stromatolite" is proposed for limestones with unique organisation and structures that occur associated with "roe-stone" (oolites). Stromatolites have a fine, more or less even layered fabric that contrasts with the concentric fabric of oolite grains.

9. A rock comprised largely of spherical grains with a specific texture is generally called an "oolite", though the name is rather silly. A new descriptive name is needed for the constituent grains of an oolite since they are not grains in the common mineralogical sense but bave a specific texture as a result of the role of phyto-organisms in their origin. I therefore propose the

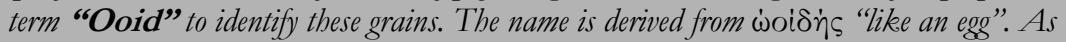
no other suitable terms are available the accumulation of so many vowels has to be excused because the term "oolite" is internationally accepted and can never be dropped. Therefore the main constituents of a true oolite are ooids.

10. The ooids of the "roe-stones" in the north German Bunter Sandstone all share the same specific primary textures. This fabric is best preserved when ooids have been cemented by calcite into a solid rock. Moreover the calcite of the ooids themselves is recrystallised and this in rare cases completely destroyed the primary texture.

The primary texture can be seen in thin sections in the size, form and arrangements of calcite crystals, and by the distribution and arrangement of allochthonous constituents like quartz. grains and clay minerals.

There is no evidence for organic textures such as those found in other zoogenic or phytogenic limestones: the biogenic constructors of oolites and stromatolites were so minute that nowadays only the texture of their aggregates or colonies are preserved.

64. When the whole area has been mapped it will be possible to understand the facies relationships. The character of the depositional basin will shed new light on the formation of oolites. It is tempting to suggest that oolites formed in salt lakes, and to connect them to salt deposits, but I am happy not to make any further comment on this.

65. Oolites are composed of ooids and the cement that lithifies them. Stromatolites are composed of thin, more or less flat laminae of calcite with a specific texture. These thin laminae are termed "Stromatoids". Stromatolites, unlike oolites, are not formed by limited individual colonies of constructing organisms; rather layers or mats of constructing organisms form them. There is a trend from ooid through poly-ooid and ooid bag to stromatolite in which the accreting layers show decreasing influence of a central nucleus in determining the form of growth.

\section{Stromatolites vary from $4 \mathrm{~cm}$ to $120 \mathrm{~cm}$ in height.}

67. Vertical sections of all stromatolites show a distinct layered texture that is accentuated by weathering. In polished sections and thin sections these basic stromatoid layers are seen to be composed of fine filaments which sometimes have a weak fan-like arrangement and a tendency to a radial structure. 
68. Recrystallisation frequently obscures the filamentous texture but has less impact on the laminations.

69. Ooids grow in all directions radially from a centre. Stromatolites grow only upwards. Stromatolites formed in situ as lithified limestone masses.

70. Stromatolites may have many different forms but these are only variations of a common theme. All were created by the same type of organism and different species cannot be distinguished.

71. Stromatolite layers are interrupted by more or less vertical partitions, termed interstices. They may be filled with clay, sand or ooids.

72. Completely flat stromatolite layers occur, but they are of limited extent. They pass laterally into weakly curved arrangements of primary layers. Interstices only exist within bulges of $20-25 \mathrm{~mm}$ diameter. Flat stromatoids are interrupted by tube-like interstices.

84. Stromatolites do not just form as layers or beds; they also occur as individual towering stem-like masses that may be called "stromatolite heads".

88. Within the Bunter Sandstone, stromatolites are always associated with oolites. They always occur above oolitic beds. The sediments overlying the stromatolites may consist of detritus, organic sediments or ooids.

94. Ooids resemble growing bacterial colonies as observed in a Petri dish. Ooids are therefore probably produced by colonies of lime-secreting phyto-organisms.

95. Ooid bags are incipient stromatolites. Stromatolites have similar growth forms to corals, sponges and plants.

96. We have to assume that simple plants gave rise to limestone precipitation.

906. My aim has been to show that the oolites and stromatolites of the north German Bunter Sandstone are inherently of organic origin. 
Stop 2: The Westerstein Reef, an Upper Permian stromatolite reef at the Harz Mountains (J. Paul)

Location: Topographic Map of Lower Saxony Sheet 4328 Bad Lauterberg, east 36 00 500, north 5719 300. Natural monument 500 m west of Bartolfelde, south of Bad Sachsa.

Geological Formation: Zechstein Group, Werra Cycle, Zechstein Limestone Formation.

Geological Age: Upper Permian, Lopingian, 250 Ma.

Description: At the onset of the Upper Permian, rifting in the north Atlantic led to flooding of the pre-existing Lower Permian Rotliegend Basin stretching from England to Belorussia (Fig. 7). The resulting Zechstein Sea had only a very restricted access to the ocean. Various sediments were precipitated depending on climate and fluctuations of the sea level. The Zechstein Group consists of seven more or less complete evaporite cycles. Cycles start with marine mudstones, followed by carbonates, sulfates, and rock salt. The climax of salinity is represented by $\mathrm{K}$ - and Mg-salts. Decreasing salinity led to precipitation in the reverse order.

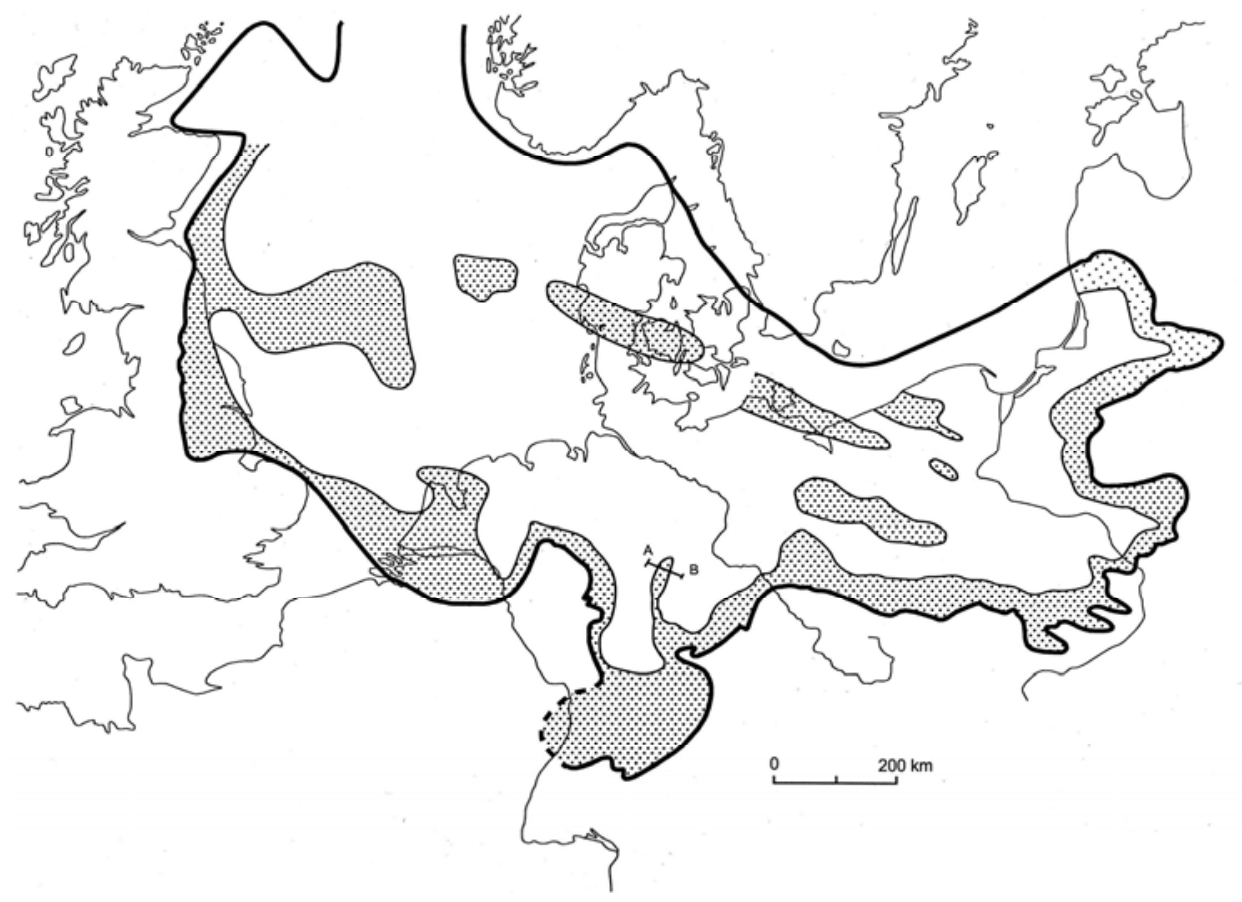

Fig. 7. The Upper Permian Zechstein Basin in Central Europe. Hatched: shallow water areas at palaeo-highs and margins. A-B: section of Fig.2. 
In central Germany, outcrops of the Zechstein Group surround the Palaeozoic Harz Mts. like a belt (Fig. 7). A palaeo-high, the Eichsfeld High, crosses this belt nearly perpendicular to the stroke of the Zechstein strata (Paul 1993). The basin facies consist of dark-grey, well bedded, some metres thick mud- and wackestone (Fig. 8). Towards the palaeo-high, limestones are replaced by dolopack- and dolograinstones. The thickness increases up to $50 \mathrm{~m}$. Carbonate buildups are present at the top of this high or above elevations like extinct volcanoes carved out by the preceding weathering (Paul 1980, 1987). Metazoan reef-builders are missing at these buildups, but they meet all definitions of reefs given by various authors: They are formed by depositional and biological processes, built significant topographic highs, were wave resistant, influenced adjacent areas. The diversity of the fauna was higher than in the surrounding, and facies belts were zoned. Micro-organisms, most likely cyanobacteria, were the frame-builders of these reefs. Zechstein reef are present in England (Smith 1981, Hollingworth \& Tucker 1987), Poland (Dyjaczynski et al 2001), Denmark and Germany (Brauch 1923, Kerkmann 1969, Füchtbauer 1980, Paul 1980, 1991, Paul \& Huckriede 2004).

\section{Eichsfeld High}

NW

SE

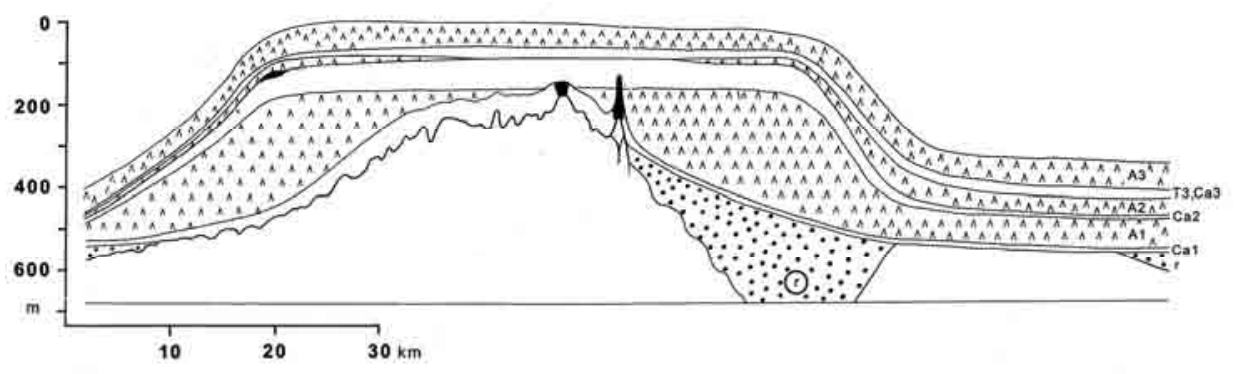

Fig. 8. Cross-section of the Eichsfeld High. Black: reefs of the Ca1 and Ca2.

The well exposed Westerstein reef is an unique example of a stromatolite reef (Fig. 9). The reef is elongate, about $200 \mathrm{~m}$ long, $50 \mathrm{~m}$ broad and up to $15 \mathrm{~m}$ high. It is situated at the top the Eichsfeld High above a natural cliff of Devonian greywackes which is exposed at the western end of the reef. The reef is better cemented than the surrounding Zechstein carbonates, and therefore it is resistant against weathering. Frame-builders are exclusively micro-organisms. Higher organised organisms, like bryozoa, brachiopods, crinoids are missing. Only one bivalve and one gastropod species have been found, respectively.

In contrast to the scarce fossil content, there is wealth of microbial structures: mats, domes, columnar forms, oncoids, and thrombolites. (Figs. 9-10). Thickness of single laminae may vary between 50 and $500 \mu \mathrm{m}$. Unfortunately, pervasive dolo- 
mitization destroyed all microscopic tissues, therefore no direct evidence of the microbial origin has been preserved. Most likely phototrophic organisms were the reef-builders due to the growth pattern of uneven or inclined surfaces (Paul 1980).

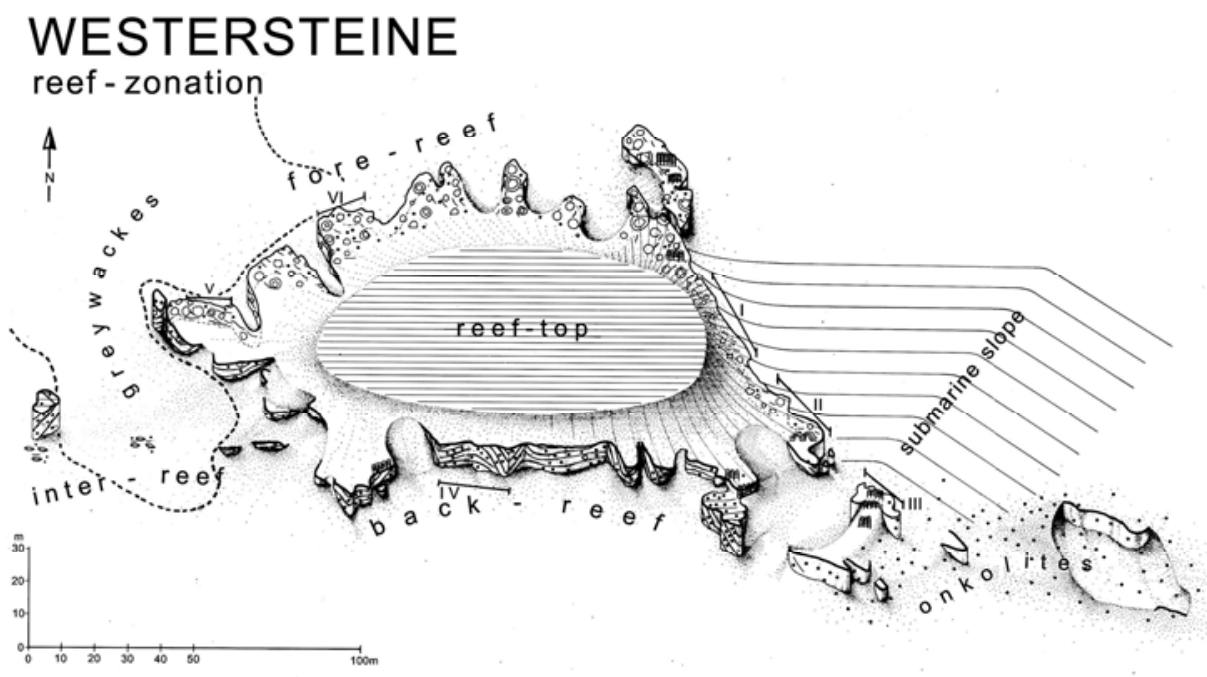

Fig. 9. The Westerstein reef. From Paul (1982).

It is possible to attribute these growth forms to different levels of energy. Undulating mats are preferentially in the lower parts of the riff, columnar stromatolites towards the east and west sides and domal structures at the upper and especially at the northern part of the reef (Fig. 11-12). Thrombolites are found at the reefplatform. Also oncoids grow preferentially on top, from where they were swept by storms to protected off-reef positions. This arrangement of various microbial forms depends on the level of wave-energy.: flat mats - columnar - domal thrombolites - oncoids. Microbial mats dip radially away from the reef-core.

The northern side of the reef is the high energy side due to the trade winds as central Europe was in the Upper Permian at a position of about $25^{\circ}$ northern latitude. The centre of the reef shifted northward due to favoured microbial production at the north side, the high energy side.

In comparison to other Zechstein reefs of the Harz Mts. and Thuringia, the Westerstein reef represents only the last phase of reef growth, when salinity was already high. The top of the Eichsfeld High was later reached by the marine transgression than basin and slope areas. There, the base of the reefs consists of wacke- and floatstones composed of crinoids, bryozoans, brachiopods, bivalves, and coated grains. Crinoids disappear with the onset of microbial bindstones. 


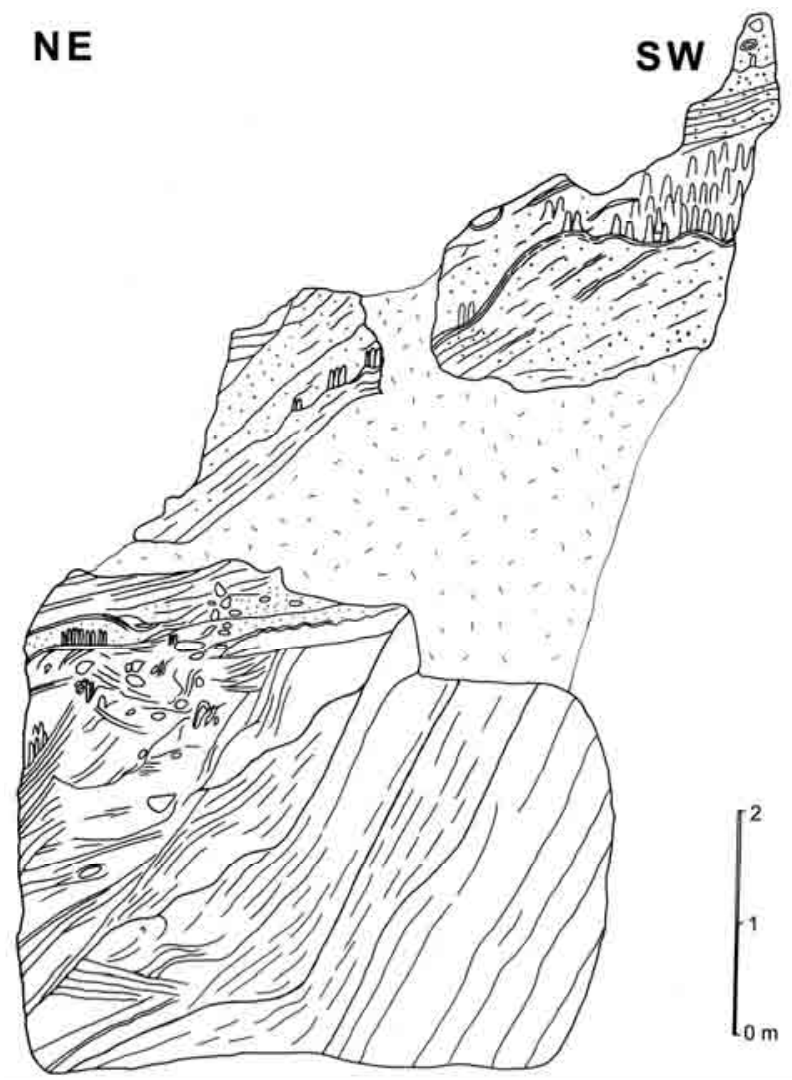

Fig. 10. Section of the northern front of the Westerstein reef.

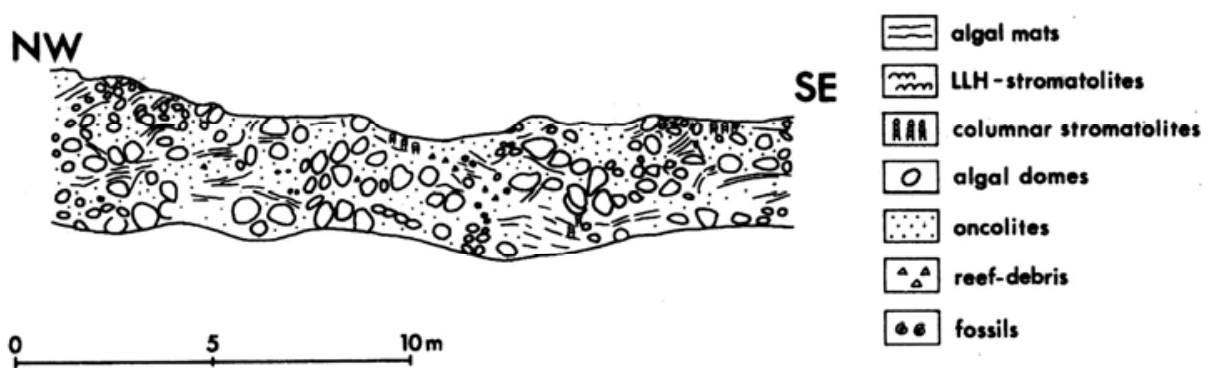

Fig. 11. View to north side of the reef. Hight of the section: $6 \mathrm{~m}$. 


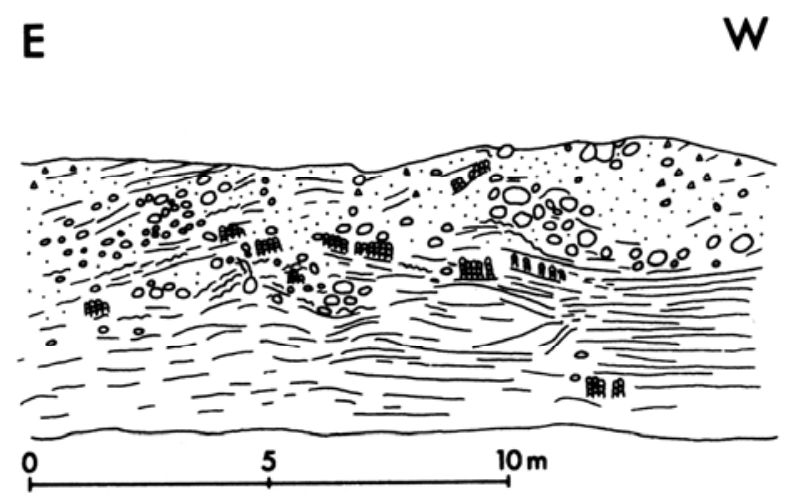

Fig. 12. View to the west side of the reef. Hight of the section: $3 \mathrm{~m}$.

Towards the top, bryozoans, brachiopods and the other fauna decline progressively and finally drop out one after the other. At top, only microbial communities like stromatolitic crusts or oncoids survived. These reduction of biodiversity may be the result of increasing salinity. A sharp fall of the sea level led to termination of reef growth and subaerial exposure (Füchtbauer 1980).

Peryt (1986) emphasized the importance of an early cementation for the rigidity and wave resistance of the reefs. Due to isotope studies, Zechstein limestones are de-dolomites (Clark 1980). A very early dolomitization took place by descending magnesium rich solutions which were the result of intense precipitation of calcium sulfate during the formation of the overlying Werra Sulfate. During later burial, higher amounts of organic matter in basinal facies favoured the formation of $\mathrm{CO}_{2}$ by microbial activity which in turn produced the calcite (Clark 1980). The amount of remaining organic matter at platforms and reefs was too low to provoke this process.

Stop 3: Quarries at Thüste, Hils Syncline (G. Arp)

Location: Geological Map of Lower Saxony 1:25000 Sheet 3923 Salzhemmendorf, R 3544 750, H 5765 500, $1 \mathrm{~km}$ ESE of the village Thüste.

Geological Formation: Münder Formation.

Geological Age: Upper Jurassic, Tithonian, ca. 142 Ma.

Description: The Thüste quarries are situated in Hils Syncline, a halotectonic depression formed during the Upper Jurassic-Lower Cretaceous (Jordan 1994). 
The area is located 30-50 km south of Hanover in the Leine Hills (Fig. 1). Jurassic marine deposition ends with the Upper Tithonian to lowermost Berriasian Münder Formation (Fig. 2), which shows a thickness varying between 150 and $800 \mathrm{~m}$ due to synsedimentary salt tectonics. This formation consists of grey and varicoloured marlstones with an oolitic limestone unit in its middle part (Herrmann et al. 1968). To the Southeast, the limestone unit is replaced by an evaporite unit containing halite, gypsum and anhydrite. Stromatolites occur within marls intercalated in, and overlying, the oolitic limestone and evaporite member (Jahnke \& Ritzkowski 1980).

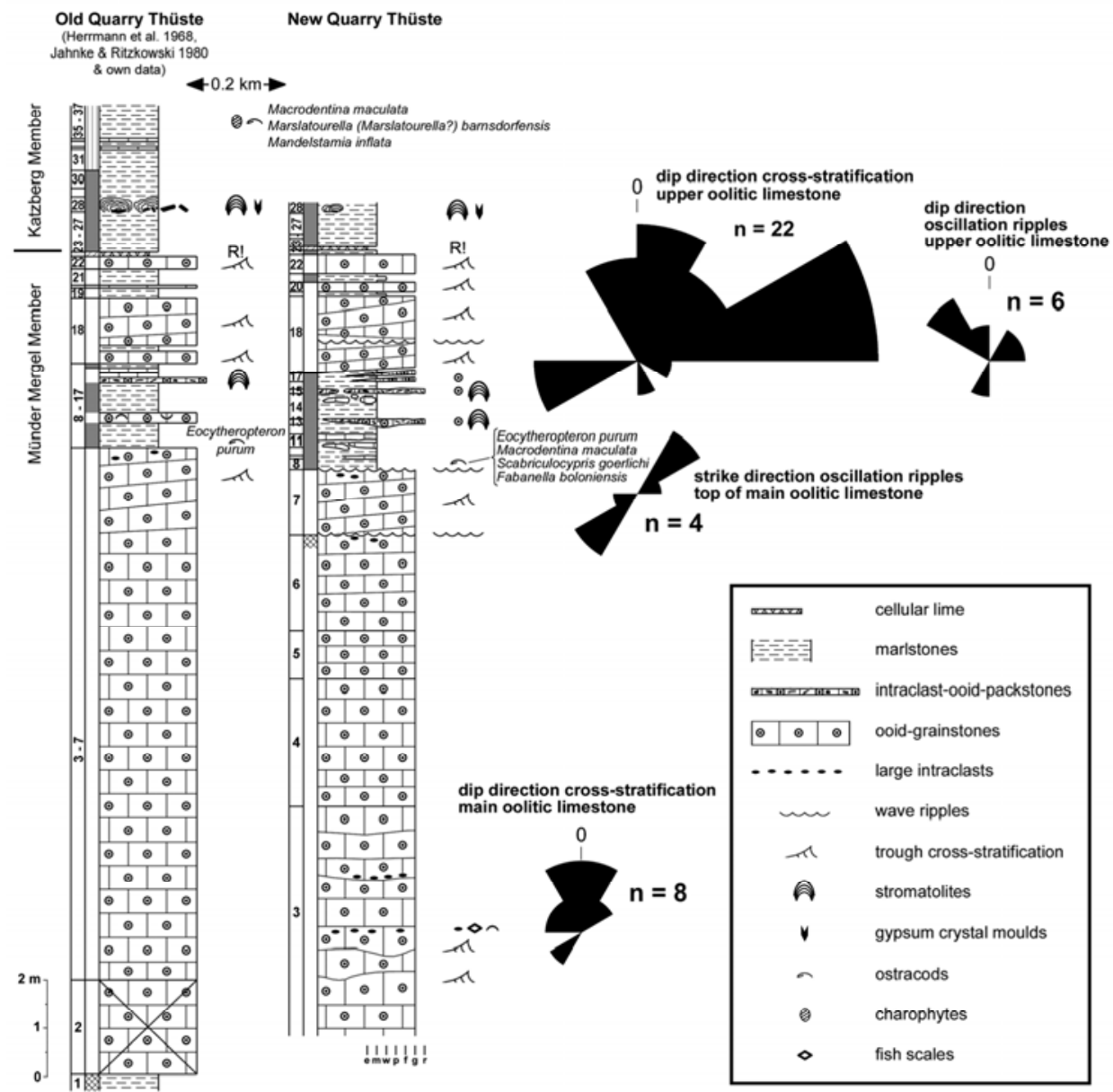

Fig. 13. Lithologic sections of the Thüste quarries showing the positions of stromatolites. Directions of cross-stratification and wave ripples in oolite member. From Arp et al. (2008). 

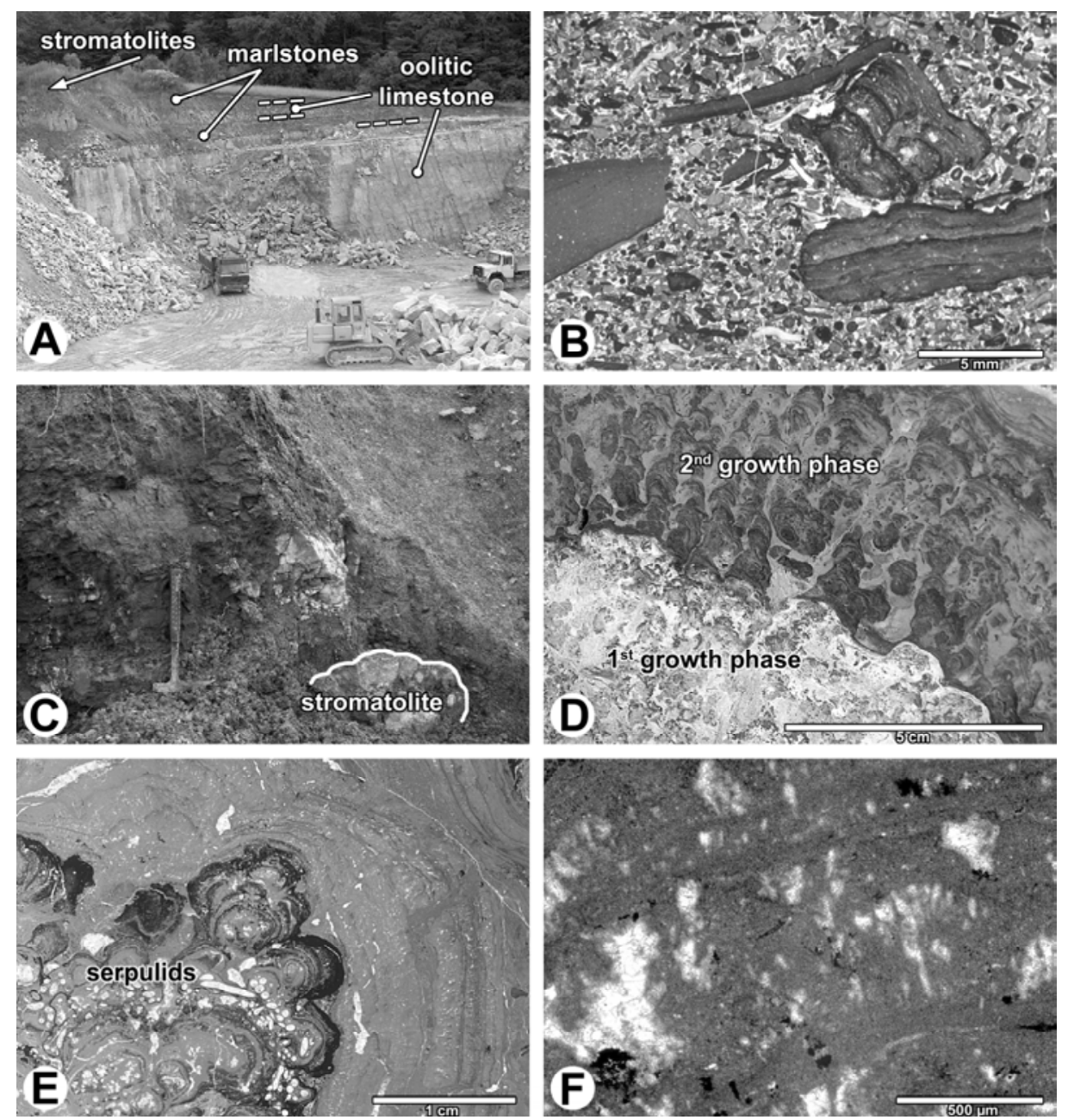

Plate 1. Stromatolites of the Münder Formation, Thüste, Hils Syncline. (A) Field view of the new Thüste quarry showing main oolitic limestone, intercalated marlstones, upper oolitic limestone and following, stromatolite-hosting marlstones. From Arp et al. (2008); (B) Stromatolite clasts within intraclast-ooid-packstone (bed 13). The packstone beds within the marlstone sequence between the oolitic limestones are interpreted as a tempestites. Thin section, transmitted light. From Arp et al. (2008); (C) Field view of stromatolite bioherm embedded in laminated dark marlstones from the uppermost section parts of Thüste (bed 28); (D) White-grey irregular and dark-grey, regular columns of first and second stromatolite bioherm growth phases. Stromatolite bioherm of bed 28. From Arp et al. (2008); (E) Discontinuous contact between the first and second stromatolite bioherm growth phases, indicated by truncation of laminae and dark pyrite impregnation. Note abundant serpulid tubes and spar-cemented evaporite moulds (light spots) in the first, irregular stromatolite phase. Thin section, transmitted light; (F) Elongated crystal traces within stromatolite laminae of second bioherm growth phase. Note angular outline of these former evaporite crystals, distinguishing them from algal filament traces. From Arp et al. (2008). 
The Thüste quarries expose the 13-15 m thick oolitic limestone unit and some meters of the following grey marls (Fig. 13; Pl. 1A). The oolites are grain-supported, well-sorted and show trough-like cross-stratification. Wave ripples occur at the top of the main oolitic limestone and $1.4 \mathrm{~m}$ below at a reddish-stained level. Dip and direction measurements of cross stratification show a high variability with a principal direction to $\mathrm{N}$, while crests of wave ripples strike SW-NE (Fig. 13). Intercalated are layers composed of bivalve shell fragments including the marine to brackish bivalve genera and rare fish scales. In addition, cm-sized, subangular to rounded micrite intraclasts, ooid grainstones and serpulid tube aggregates occur at the base of cross-beds. Above the rippled top of the "main oolitic limestone" a $2 \mathrm{~m}$-thick interval of dark-grey mudstones and concretionary limestone beds follows, both with tiny plant debris. Intercalated are intraclast-ooid-packstones composed of reworked ooids, flat pebbles (mudstones, rare ooid grainstones) and angular stromatolite clasts up to several centimeter in size (Pl. 1B). The contact between packstones and embedding mudstones is sharp. No bioturbation has been observed. However, some oolite layers intrude into minor mud cracks of mudstones below. Gypsum crystal traces occur within mudstones, while dolomite rhombs are preferentially found within packstone layers.

On top of the mudstones interval, a second oolitic limestone bed of $2.3 \mathrm{~m}$ thickness is developed (Fig. 13). The trough cross-stratified oolites interfinger with the mudstone interval below and show thin marlstone intercalations near their top. Again, symmetric wave ripples are developed at one level, $55 \mathrm{~cm}$ above base. As in the "main oolite limestone" cross-stratification shows a high variability, however now pointing to northeastern directions. In accordance to that, wave ripples show bidirectional foresets dipping to NW and SE, respectively (Fig. 13).

Above the second oolitic limestone bed dark, well stratified to laminated marlstones follow, with a residual bed near the base. $80 \mathrm{~cm}$ above the base, a prominent stromatolite bioherm horizon is developed (Pl. 1C). This bioherm horizon initiated upon reworked stromatolite clasts and shows two growth phases (Fig. 14). The first bioherm growth phase is formed by 1 to $10 \mathrm{~cm}$ high, irregulardendroid stromatolite columns and white-grey marl pockets between. Locally, serpulid tubes occur near the top of this growth phase (Pl. 1D-E). The second growth phase forms dark-grey rigid crusts up to $10 \mathrm{~cm}$ thick with regular columns and laterally linked hemispheroids at upper bioherm parts, and smooth, steep to overhanging sides. Finally, $30 \mathrm{~cm}$ above the stromatolitic bioherms, the laminated dark-grey marls turn into poorly stratified greenish-grey marls with thin micritic limestone beds, which form the top of the section.

Tithonian stromatolites of the Münder Formation at Thüste, N-Germany, have traditionally been considered having formed by intertidal cyanobacterial communities (Jahnke \& Ritzkowski 1980, Dragastan \& Richter 2001). However, thin sections of the stromatolites show elongated angular traces of former gypsum crystals in a dense arrangement, but no algal or cyanobacterial filament traces. 


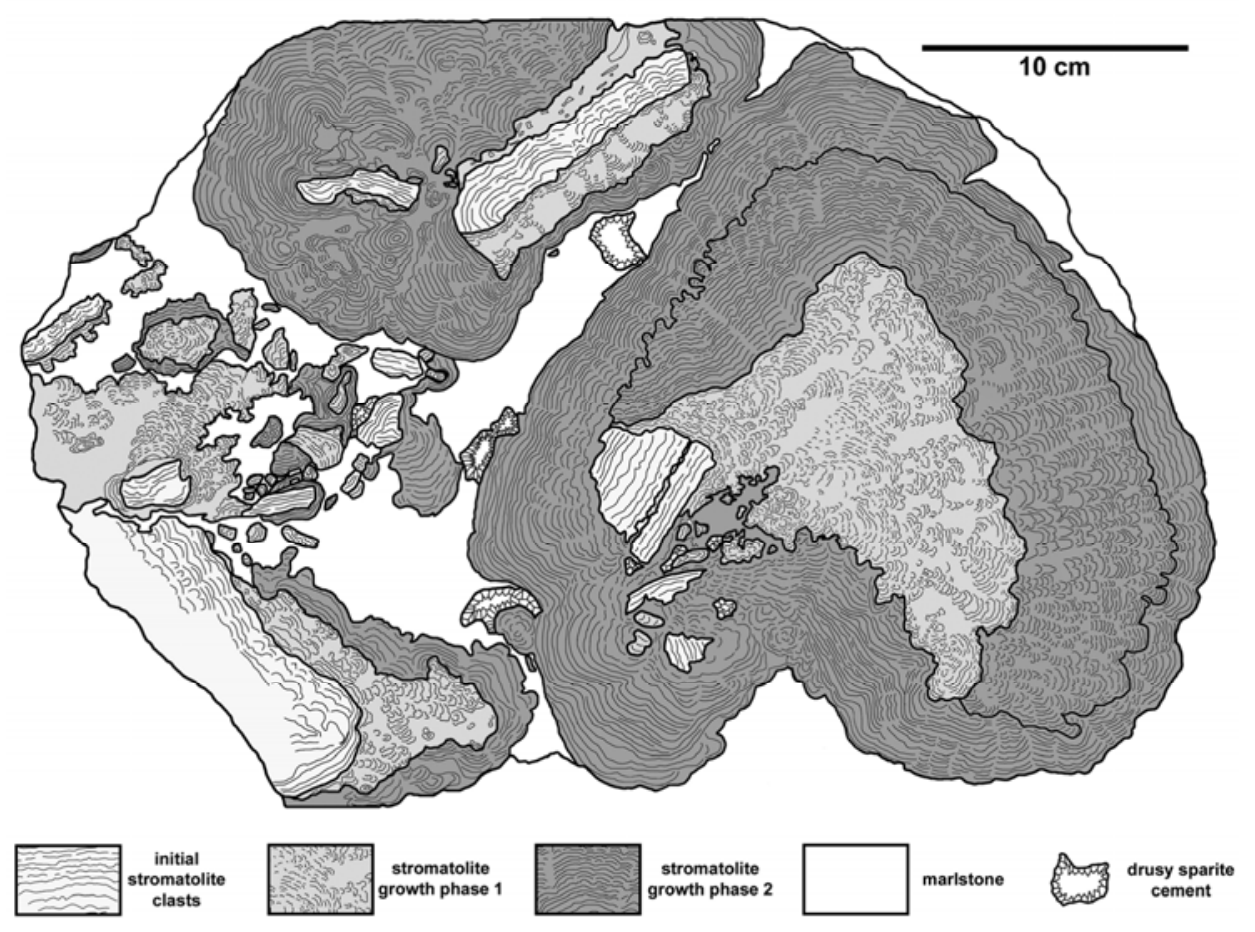

Fig. 14. Drawing of stromatolite bioherm oblique cross-section showing initial stromatolite clasts, first and second bioherm growth phases and embedding marlstone. Note several discontinuities in growth, associated with rotation of the bioherm. From Arp et al. (2008).

Moreover, high $\mathrm{Fe}^{2+}$ and $\mathrm{Mn}^{2+}$ contents, oxygen- and sulfur-isotope ratios of carbonate-bound sulfates, and sulfurized hydrocarbon biomarkers of the stromatolitic carbonate indicate that $\mathrm{CaCO}_{3}$ precipitation occurred near the oxic-anoxic interface as a result of intensive bacterial sulfur cycling rather than photosynthetic activity (Arp et al. 2008). Furthermore, anaerobic oxidation of methane by Archaea may have driven $\mathrm{CaCO}_{3}$ precipitation in deeper parts of the biofilm community, as reflected by high concentrations of squalane with a strongly negative $\delta^{13} \mathrm{C}$ in conjunction with evaporite pseudomorphs showing extremely low $\delta^{13} \mathrm{C}_{\text {Carb }}$ ratios. Consequently, the Thüste stromatolites are now interpreted as having initially formed by gypsum impregnation of biofilms (Arp et al. 2008). Subsequently, early $\mathrm{Mg}$-calcitic calcitization within the biofilms occurred due to combined bacterial iron, manganese and sulfate reduction, with increasing contribution of anaerobic oxidation of methane with depth (Arp et al. 2008). This model plausibly explains the prominent preservation of signals derived from oxygen-independent metabolic pathways, whereas virtually no geochemical record exists for an aerobic community that may nevertheless have prevailed at the stromatolite surface. Sedi- 
mentological investigations suggest that the stromatolite bioherms of Thüste grew in a predominantly subaquatic lagoonal setting, behind an oolite shoal and in front of a shoreline with gypsum stromatolites and arenites passing into a sabkha (Fig. 16; Arp et al. 2008).

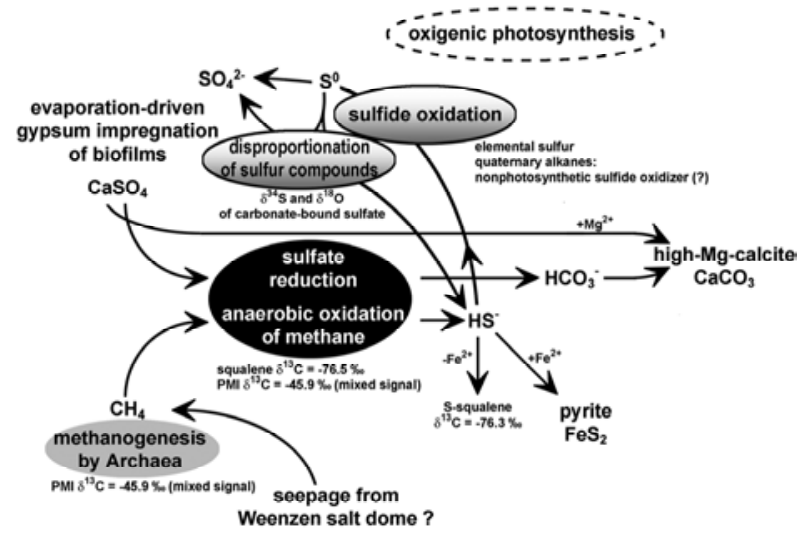

Fig. 15. Microbial processes and functional groups involved in gypsum calcification and stromatolite formation in the Münder Formation at Thüste. From Arp et al. (2008).

NW

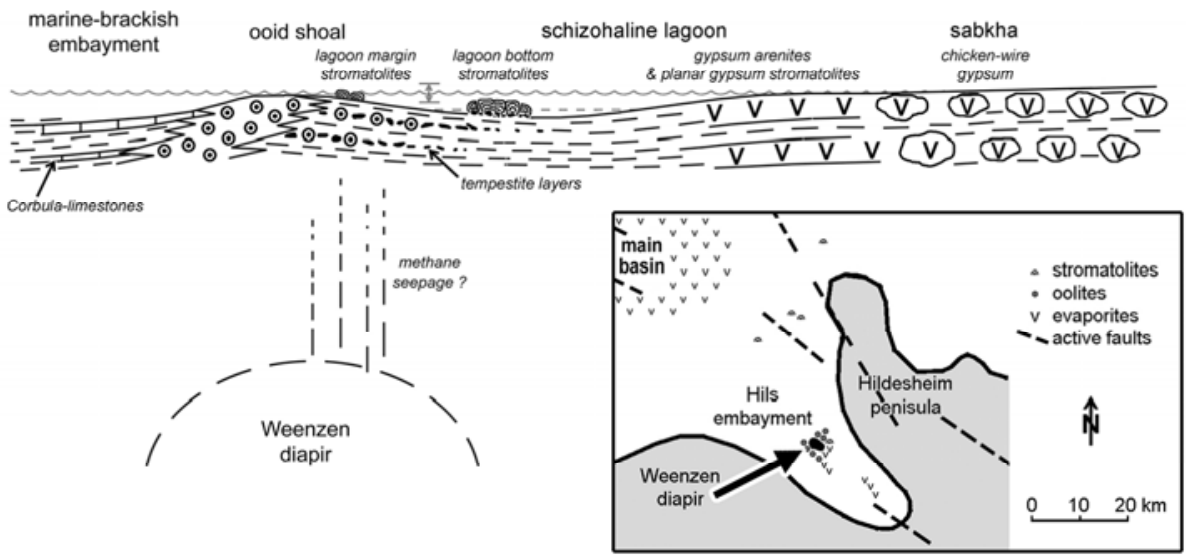

Fig. 16. Facies model and Tithonian palaeogeography of the Hils embayment. Synsedimentary faults and presumed coast line according to Hoyer (1965) and Ziegler (1990). From Arp et al. (2008). 
This lagoon was affected by alternating stagnant closed conditions (with laminated marls, stromatolite growth and minor evaporite deposition) and hydrologically open conditions (with influx from the marine-brackish embayment). Brecciation of stromatolites occurred during prolonged hydrological closure, evaporative drawdown of water level and consecutive subaerial exposure, salt wedging and insolation. Sporadic storm and flooding events redistributed mud and stromatolite clasts on desiccated marginal-lagoonal mudflats, and caused their mixture with particles from the oolite shoal in proximal parts of the lagoon (Fig. 16).

\section{Stop 4: Quarry Iberg-Winterberg north of Bad Grund, Harz Mountains (J. Reitner)}

Location: Geological Map of Lower Saxony 1:25000 Sheet 4127 Seesen, R 3585 900, H 5744300.

Geological Formation: Iberg Limestone, Kulm Greywackes.

Geological Age: Middle Devonian to Lower Carboniferous, 385-330 Ma.

Description: The Iberg-Winterberg quarry with its more than $70 \mathrm{~m}$ high walls exposes large parts of an Middle-Upper Devonian reef complex (i. e., Iberg Limestone) together with its hanging wall greywacke-shale series of Lower Carboniferous age (Hinze 1976). The total thickness of the Iberg Limestone is unknown, but may be about $600 \mathrm{~m}$ (Franke 1973). The drilling Iberg 1 at the Winterberg quarry transsected $350 \mathrm{~m}$ of limestone and did not reach the assumed volcanic basement below (Franke 1973). Facies mapping revealed an atoll structure of the Iberg limestone complex, with off reef (e. g., bioclastic turbidites with reef components), fore reef (e. g., stromatoporoid rudstones with rugose and tabulate corals, bioclastic grainstones) and back reef carbonates (e. g., bioclastic grainstones with low-diversity fauna, micrites with fenestrae; Franke 1973). A central reef zone was very small as in many other reef complexes of the same geological time. Such reef core carbonates were composed of bound- and rudstones with large massive stromatoporoids.

Reef growth ceased end of the Frasne and further subsidence turned the drowned atoll to a seamount (Fig. 17). During the Famennian, Tournaisian and Visean, depressions in the dead reef surface, the pore space of a large internal breccia, and multiple phases of neptunian dikes were filled a variety of fossil-rich limestones (Fig. 17; Gischler 1992), among them floatstones with deep-water corals (e. g., the tabulate Cladochonus and the rugose Caninia; Gischler 1996). During the uppermost Visean, siliciclastic turbidites (Hercynian flysch) derived from the Mid-German Crystalline High covered the seamount. 


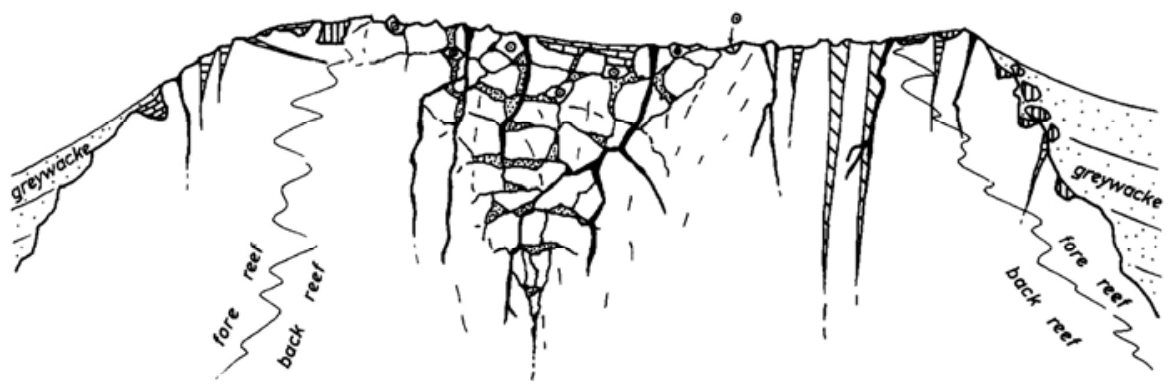

\section{Uppermost Visean superposition}

XII, XIII

Қपण Upper Visean dikes

$\mathrm{IX}, \mathrm{X}$, greywacke, shale

\section{U1, Upper Visean superposition}

\section{Upper Tournaisian-upper Visean \\ breccia matrix \\ VI, VII, VIII, tuffites}

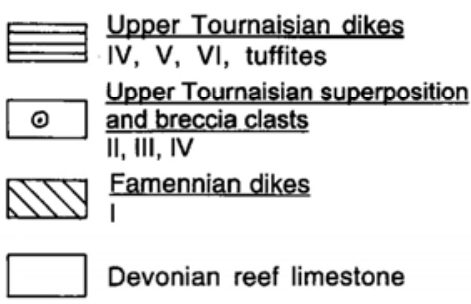

Upper Tournaisian dikes

IV, V, VI, tuffites

and breccia clasts

Devonian reef limestone

Fig. 17. Schematical drawing of top parts of the Iberg reef complex to illustrate the occurrence of Famennian to Visean post-reef rocks. From Gischler (1996).

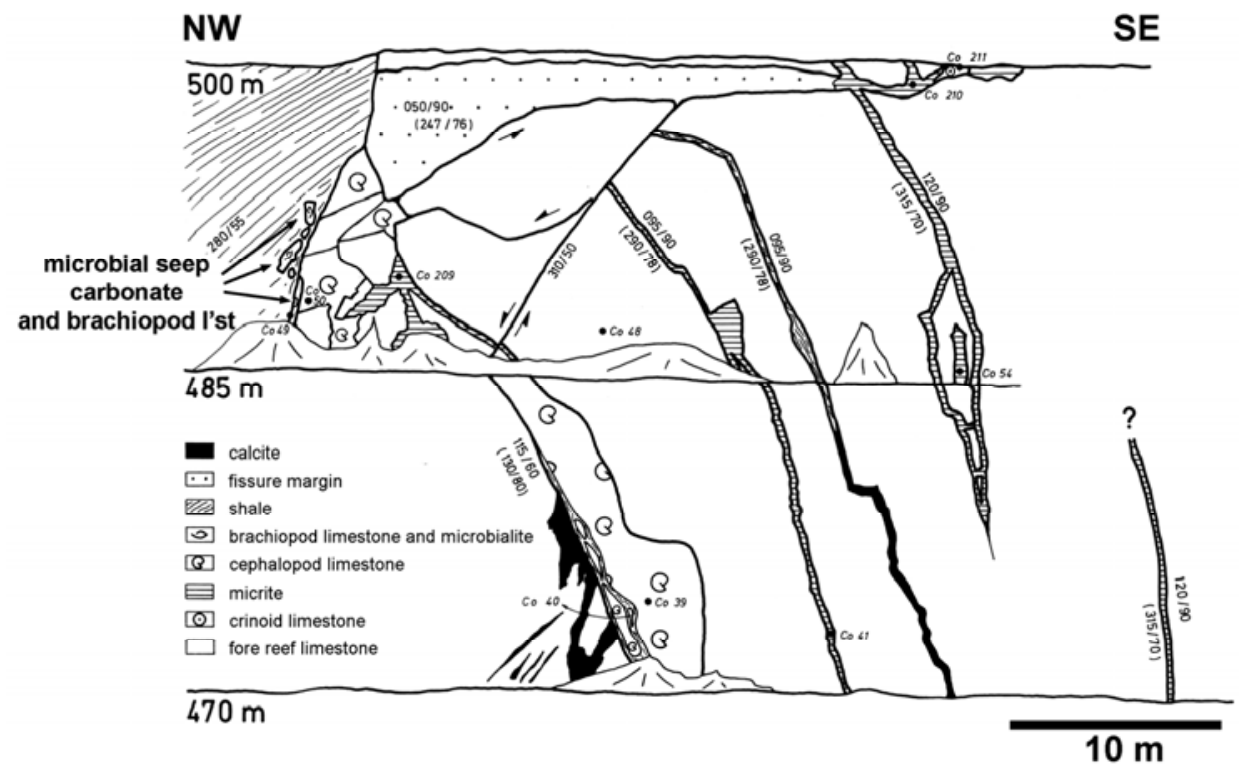

Fig. 18. Contact between the Givetian-Frasnian Iberg reef complex and Lower Carboniferous shales and greywackes at the Winterberg quarry. Reef and fore reef carbonates are transected by numerous neptunian dikes filled with Tournaisian goniatiteand micrite limestones and Lower Visean shales. Note microbial seep carbonates and brachiopod limestones in depressions and as clasts at the tectonically altered reefcomplex/flysch boundary. From Gischler (1992). 
Of special interest are small microbial buildups associated with a monospecific brachiopod fauna, which occur at the contact of the Givetian-Frasnian reef carbonates to the uppermost Visean Carboniferous greywacke succession (Fig. 18; Peckmann et al. 2001). These stromatolitic and thrombolitic boundstones belong to the Gnathodus nodosus conodont zone, i. e. are of Late Visean age. They are mostly composed of calcite replacing former aragonite cement and occur in depressions and shallow caves within the former reef surface (Gischler 1996, Peckmann et al. 2001). Elevated quartz grain contents in brachiopod and microbial limestone document increasing clastic input. The very negative $\delta^{13} \mathrm{C}$ values of the microbial boundstones and isopacheous cements in the brachiopods (Fig. 19) indicate that these are hydrocarbon seep carbonates, with thermogenic methane as the most likely source of carbonates (Peckmann et al. 2001). The monospecific assemblage of the brachiopod Ibergirbynchia, finally, is considered to represent an ancient chemosymbiotic community (Gischler et al. 2003).

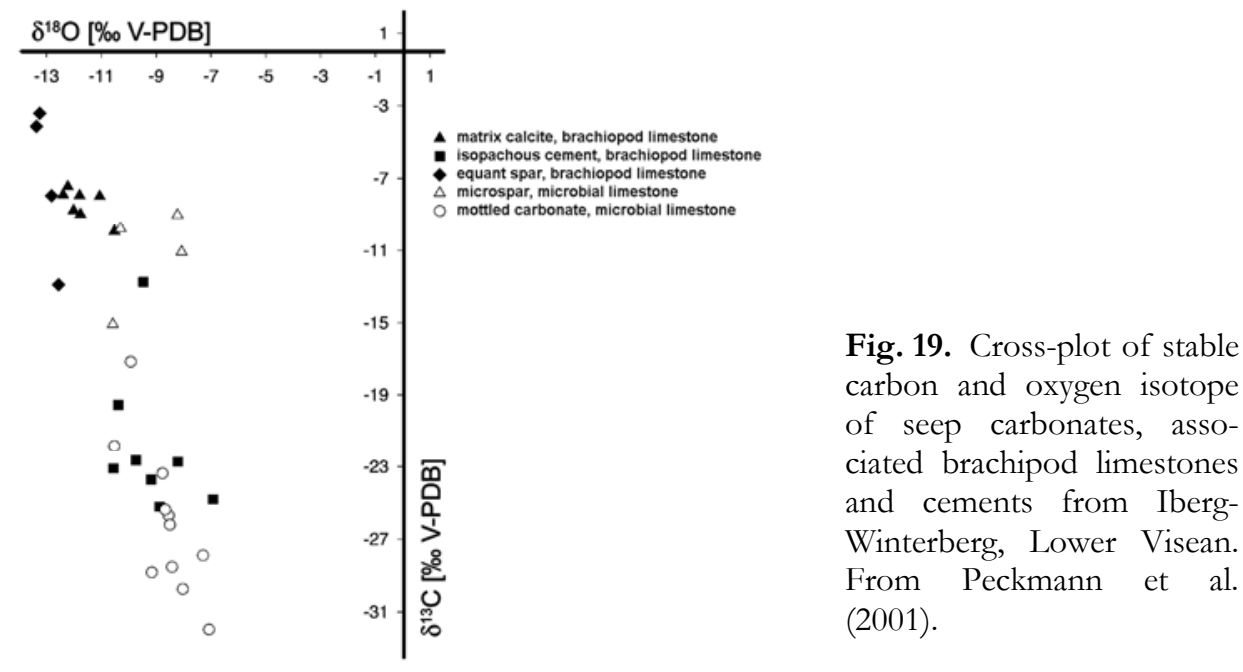

\section{References}

Arp, G. \& Mennerich, C. 2008. Ostracod associations, palaeoenvironment and cyclicity of Purbecktype sediments of the Münder Formation (Lower Cretaceous, Hils Syncline, N-Germany). Palaeogeography Palaeoclimatology Palaeoecology 264: 230-249.

Arp, G.; Bielert, F.; Hoffmann, V.-E. \& Löffler, T. 2005. Palaeoenvironmental significance of lacustrine stromatolites of the Arnstadt Formation ("Steinmergelkeuper", Upper Triassic, NGermany). Facies 51: 419-441.

Arp, G.; Hoffmann, V.-E.; Seppelt, S. \& Riegel, W. 2004. Exkursion 6: Trias und Jura von Göttingen und Umgebung. In: Reitner, J., Reich, M. \& Schmidt, G. (eds.): Geobiologie 2. 74. Jahrestagung der Paläontologischen Gesellschaft, 2.-8.10.2004: 147-192, Göttingen (Universitätsverlag). 
Arp, G.; Ostertag-Henning, C.; Yücekent, S.; Reitner, J. \& Thiel, V. 2008. Methane-related microbial gypsum calcitization in stromatolites of a marine-evaporative setting (Münder Formation, Upper Jurassic, Hils Syncline, north Germany). Sedimentology 55: 1227-1251.

Betzler, C.; Pawellek, T.; Abdullah, M. \& Kossler, A. 2007. Facies and stratigraphic architecture of the Korallenoolith Formation in North Germany (Lauensteiner Pass, Ith Mountains). Sedimentary Geology 194: 61-75.

Brauch, W. 1923. Verbreitung und Bau der deutschen Zechsteinriffbildungen. Geologisches Archiv 2: 100-187.

Brückmann, F. E. 1721. Specimen physicum exbibens Historiam naturalem Oolithi. - 28 pp., Helmstedt (Salomon Schnorr).

Burne, R. V. \& Moore, L. S. 1987. Microbialites: Organosedimentary deposits of benthic microbial communities. Palaios 2: 241-254.

Clark, D. N. 1980. The diagenesis of Zechstein carbonate sediments. Contributions to Sedimentology 9: 167-203.

Dragastan, O. \& Richter, D. K. 2001. Non-marine calcareous algae of Upper Jurassic to Lower Cretaceous sequences from the Weserbergland (Northwest Germany). Geologica Carpathica 52: 301318.

Dyjaczynski, K.; Gorski, M.; Mamczur, S. \& Peryt, T. M. 2001. Reefs in the basinal facies of the Zechstein Limestone (Upper Permian) of Western Poland: A new gas play. Journal of Petroleum Geology 24: 265-285.

Franke, W. 1973. Fazies, Bau und Entwicklungsgeschichte des Iberger Riffes (Mitteldevon bis Unterkarbon III, NW-Harz, W-Deutschland). Geologisches Jabrbuch (A) 11: 3-127.

Franke, W. 1999. Tectonic and plate tectonic units at the North Gondwana Margin: Evidence from the Central European Variscides. Abhandlungen der Geologischen Bundesanstalt 54: 7-13.

Füchtbauer, H. 1980. Composition and diagenesis of a stromatolitic bryozoan bioherm in the Zechstein 1 (northwestern Germany). Contributions to Sedimentology 9: 233-251.

German Stratigraphic Commission (ed.) 2002. Stratigraphische Tabelle von Deutschland 2002. - 1 poster, Potsdam (GeoForschungsZentrum).

Gischler, E. 1992. Das devonische Atoll von Iberg und Winterberg im Harz nach Ende des Riffwachstums. Geologisches Jabrbuch (A) 129: 5-193.

Gischler, E. 1996. Late Devonian-early Carboniferous deep-water coral assemblages and sedimenttation on a Devonian seamount: Iberg Reef, Harz Mts., Germany. Palaeogeography Palaeoclimatology Palaeoecology 123: 297-322.

Gischler, E.; Sandy, M. R. \& Peckmann, J. 2003. Ibergirhynchia contraria (F. A. Roemer, 1850), an early Carboniferous seep-related rhynchonellide brachiopod from the Harz Mountains, Germany - a possible successor to Drieduszyckia? Journal of Paleontology 77: 293-303.

Helm, C. \& Schülke, I. 1998. A coral-microbialite patch reef from the Late Jurassic (florigemmaBank, Oxfordian) of NW Germany (Süntel Mountains). Facies 39: 75-104.

Herrmann, R.; Fricke, W.; Graupner, A.; Grosse, B. \& Hoffmann, K. 1968. Erläuterungen zur Geologischen Karte von Niedersachsen 1 : 25000 Blatt 3923 Salzhemmendorf. - 133 pp., 1 map, Hannover (Niedersächsisches Landesamt für Bodenforschung).

Hinze, C. 1976. Erläuterungen zur geologischen Karte von Niedersachsen 1 : 25000. Blatt Nr. 4127 Seesen. 161 pp., 2 maps, Hannover (Niedersächsisches Landesamt für Bodenforschung).

Hollingworth, N. T. J. \& Tucker, M. E., 1987. The Upper Permian (Zechstein) Tunstall Reef of North East England: palaeoecology and early diagenesis. Lecture Notes in Earth Sciences 10: 23-51.

Hoyer, P. (1965): Fazies, Paläogeographie und Tektonik des Malm im Deister, Osterwald und Süntel. Beibefte zum Geologischen Jabrbuch 61: 1-249. 
Jahnke, H. \& Ritzkowski, S. (1980): Die Fazies-Abfolge im Münder Mergel der Steinbrüche bei Thüste (Ober-Jura, Hilsmulde). Berichte der Naturbistorischen Gesellschaft Hannover 123: 45-62.

Jordan, H. 1994. Erläuterungen zur geologischen Karte von Niedersachsen 1: 25 000. Blatt Nr. 4024 Alfeld. 126 pp., 1 map., Hannover (Niedersächsisches Landesamt für Bodenforschung).

Kalkowsky, E. 1908. Oolith und Stromatolith im norddeutschen Buntsandstein. Zeitschrift der Deutschen geologischen Gesellschaft 60: 68-125.

Kerkmann, K. 1969. Riffe und Algenbänke im Zechstein von Thüringen. Freiberger Forschungshefte (C) 252: $85 \mathrm{pp} .$.

Paul, J. 1980. Upper Permian algal stromatolite reefs, Harz Mountains (F.R. Germany). Contributions to Sedimentology 9: 253-268.

Paul, J. 1982. Der Untere Buntsandstein des Germanischen Beckens. Geologische Rundschau 71: 795811.

Paul, J. 1987. Zechstein am Harzrand: Querprofil über eine permische Schwelle. In: Kulick, J. \& Paul, J. (eds.): Zechstein 87. International Symposium. Kassel/Hannover. Exkursionsfübrer II: 193-276, KasselHannover.

Paul, J. 1991. Zechstein carbonates: marine episodes of an hyperhaline sea. Zentralblatt für Geologie und Paläontologie (Teil I) [1991]: 1029-1045.

Paul, J. 1993. Anatomie und Entwicklung eines permo-triassischen Hochgebietes: die EichsfeldAltmark-Schwelle. Geologisches Jabrbuch (A) 131: 197-218.

Paul, J. 1999. Fazies und Sedimentstrukturen des Buntsandsteins. In: Hauschke, N. \& Wilde, V. (eds.): Trias - Eine ganz andere Welt: 105-114, München (Pfeil Verlag).

Paul, J. \& Huckriede, H. 2004. Riffe, Gips und Erze: Zechstein zwischen Saalfeld und Neustadt/Orla. Schriftenreibe der deutschen geologischen Gesellschaft 35: 75-91.

Paul, J. \& Peryt, T. M. 2000. Kalkowsky's stromatolites revisited (Lower Triassic Buntsandstein, Harz Mountains, Germany). Palaeogeography Palaeoclimatology Palaeoecology 161: 435-458.

Peckmann, J.; Gischler, E.; Oschmann, W. \& Reitner, J. 2001. An early Carboniferous seep community and hydrocarbon-derived carbonates from the Harz Mountains, Germany. Geology 29: 271-274.

Peryt, T. M 1986. Zechstein Stromaria (=Archaeolithoporella)-recement reefs in Thuringia. Neues Jabrbuch für Geologie und Paläontologie, Monatshefte [1986]: 307-316.

Shiraishi, F.; Bissett A.; Beer, D. de; Reimer, A. \& Arp, G. 2008a. Photosynthesis, respiration and exopolymer calcium-binding in biofilm calcification (Westerhöfer and Deinschwanger Creek, Germany). Geomicrobiology Journal 25: 83-94.

Shiraishi, F.; Bissett A., Beer, D. de; Reimer, A. \& Arp, G. 2008b. Microbial effects on biofilm calcification, ambient water chemistry and stable isotope records (Westerhöfer Bach, Germany). Palaeogeography Palaeoclimatology Palaeoecology 262: 91-106.

Smith, D. B. 1981. The Magnesium Limestone (Upper Permian) Reef Complex of Northeastern England. Society of Economic Paleontologists and Mineralogists, Special Publication 30: 187-202.

Usdowski, H.-E. 1962. Die Entstehung der kalkoolithischen Fazies des norddeutschen Buntsandsteins. Beiträge zur Mineralogie und Petrographie 8: 141-179.

Ziegler, P. A. 1990. Geological Atlas of Western and Central Europe. $2^{\text {nd }}$ ed. - 239 pp., 52 enclosures, The Hague (Shell Internationale Petroleum Maatschapij B.V.). 


\title{
Excursion B:
}

\section{Post-Conference Field Trip}

\author{
Fossil and present-day stromatolites of southern Germany \\ Gernot Arp \\ Geowissenschaftliches Zentrum, Georg-August-Universität Göttingen, Abt. Geobiologie, Göttingen, \\ Germany; E-mail:garp@gwdg.de
}

\section{Introduction}

South Germany with its Franconian and Swabian Alb is a classical area of geology and palaeontology. This is especially true for the fossiliferous Jurassic (Quenstedt 1858), where a number of stratigraphic terms have been coined (e. g., Pliensbachian, Oppel 1856-1858; Aalenian, Meyer-Eymar 1864, Dietl \& Etzold 1977) and fossils of the famous Fossillagerstätten Posidonia Shale and Solnhofen Lithographic Limestone have already been described and figured in the $17^{\text {th }}$ and $18^{\text {th }}$ century (e. g. the Swabian Caput Medusae of Hiemer 1724: Hölder 1994, Reich in press; fossil fish and decapod crustacean of Solnhofen: Knorr \& Walch 17551771). Apart from that, the sedimentary succession provides a number of microbialites occurrences, some of them of considerable volume such as the spongemicrobialite mounds of the Upper Jurassic (Stop 1). The location of the microbialite sites visited during this field trip is provided in Fig. 1.

The general geological setting of southern Germany is characterized by a folded, low to high-grade metamorphic Variscian basement (Precambrian-Lower Carboniferous metasediments and Upper Carboniferous granites), unconformably overlain by local Lower Permian intramontane molasse sediments and an up to $1 \mathrm{~km}$ thick Mesozoic cover composed of alternating marine and non-marine sediments. The Variscian basement was formed by the Late Paleozoic collision of microcontinents (terranes) and their accretionary wedges between Gondwana and Laurussia (Franke 1999). This collision is part of the formation of the supercontinent Pangaea. Today, Varician basement rocks are uplifted and exposed in the northeastern parts of Bavaria (Bayerischer Wald, Fichtelgebirge, Frankenwald), separated from the South-German Block by a Cretaceous-Tertiary fault system (Fig. 1). 


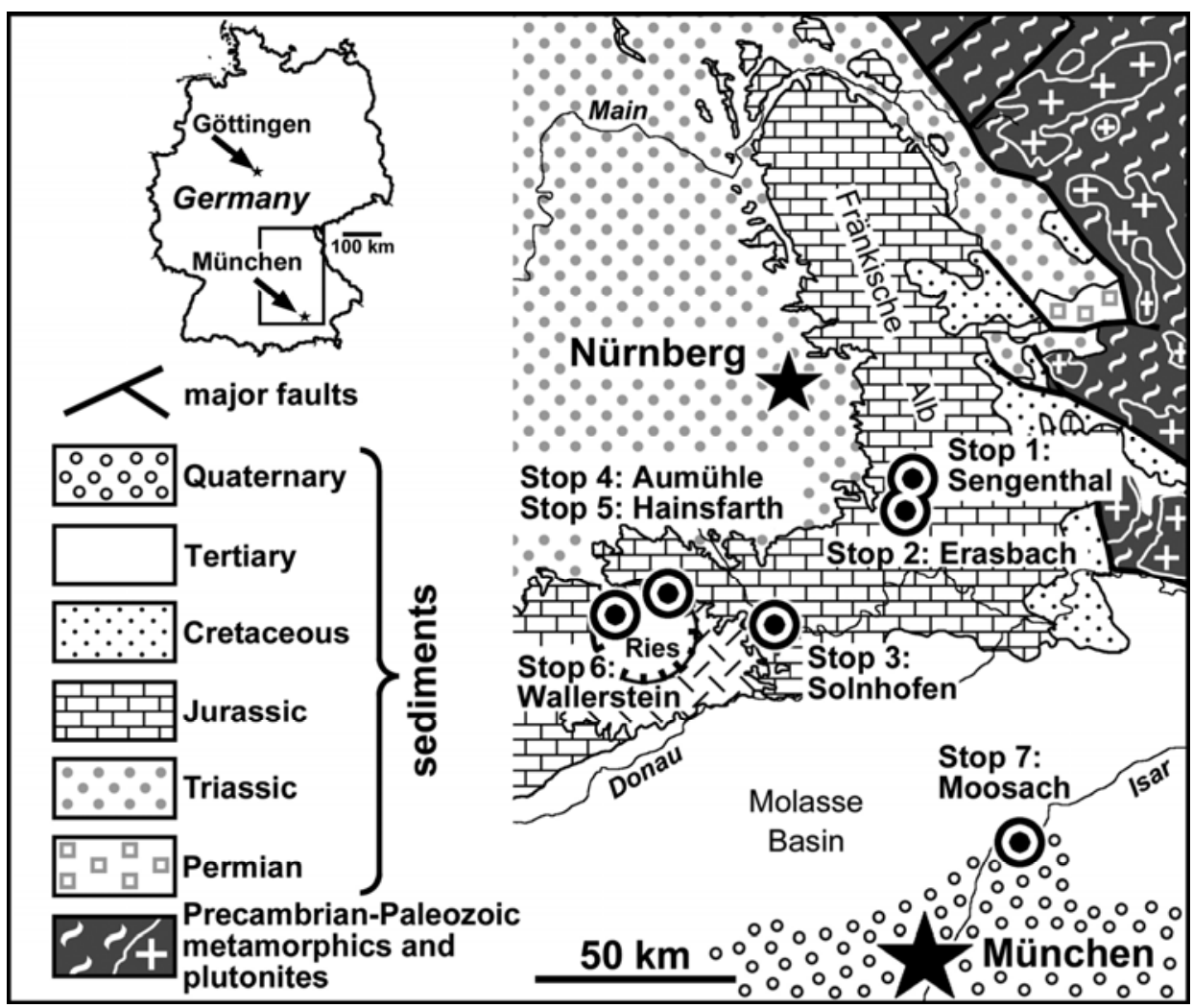

Fig. 1. Simplified geological map of the post-symposium field trip area with location of the stops.

Lower Permian intramontane molasse sediments of the Rotliegend Group, which formed in strike-slip-fault basins during the erosion of the Varician fold belt, are widespread in the subsurface of northern Bavaria. However, only a few surface exposures are visible near the above mentioned fault system. The Upper Permian evaporites of the Zechstein Group, which forms one of the most important formations in northern Germany, wedge out to the south. Similarily, the Triassic formation of the Buntsandstein (mainly fluvial to lacustrine red beds), Muschelkalk (mainly shallow-marine carbonates) and Keuper (mainly fluvial to lacustrine red beds) successively overstep the former margin of the Germanic Basin in southward direction (Fig. 2).

The Jurassic of the region is characterized by a division into three units: The darkgrey marine marlstones of the Schwarzjura Group ("Black Jurassic", Urlichs 1977), the brown marine sandstones and iron oolites of the Braunjura Group ("Brown Jurassic", Dietl 1977), and finally the white-grey marine limestones and reef carbonates of the Weißjura Group ("White Jurassic", Ziegler 1977; Fig. 2). 


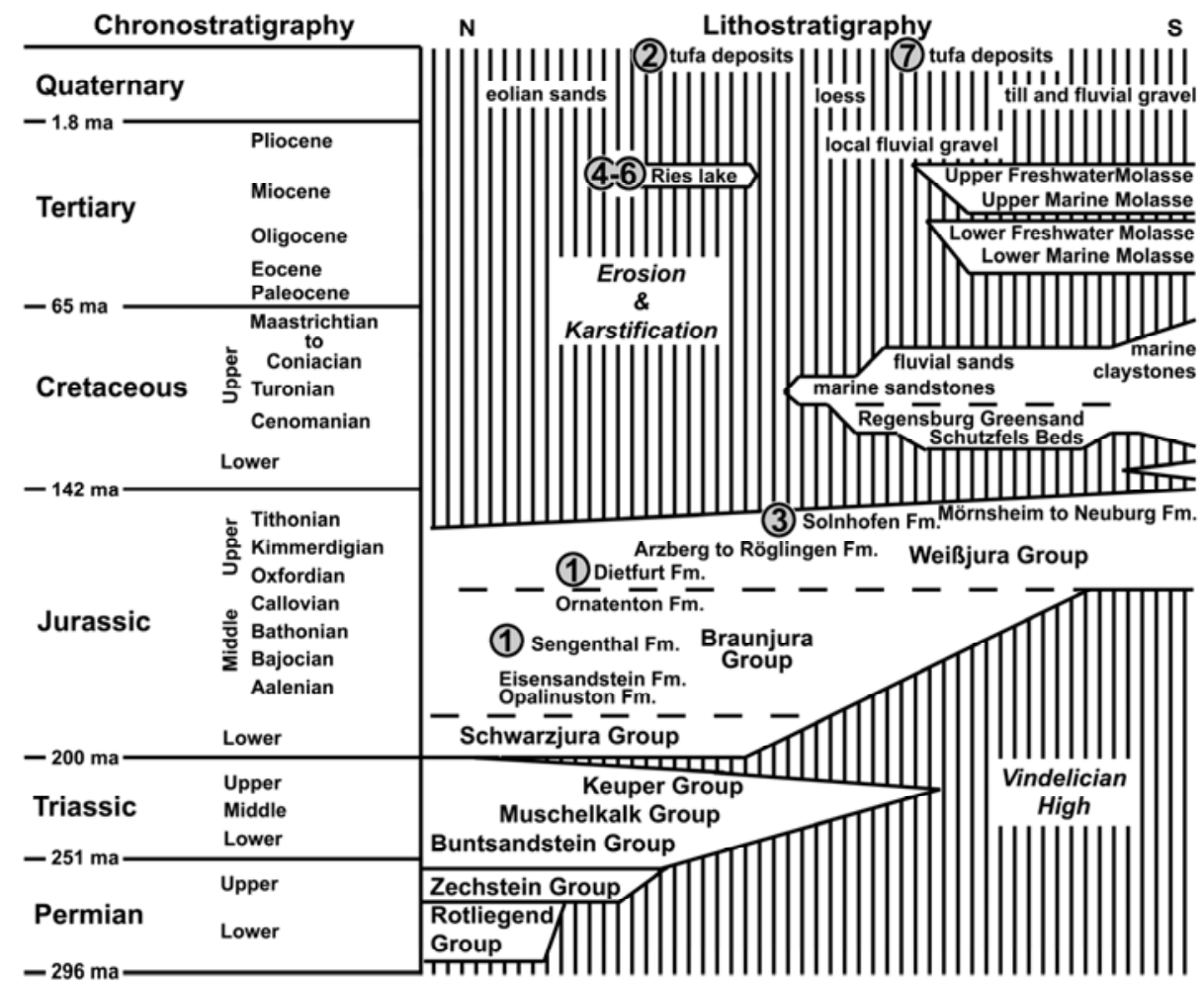

Fig. 2. Stratigraphic overview of the post-Variscian sedimentary succession of the field trip area. Numbers indicate microbialite occurrences visited during this field trip. Absolute ages and stratigraphic terms according to German Stratigraphic Commission (2002).

The Lower Jurassic Schwarzjura and Middle Jurassic Braunjura Group are characterized by siliciclastic influx from the East European craton and Bohemian massif with only minor carbonate sedimentation. During that time, a narrow landmass located at the latitude of Munich, the so-called Vindelician High, formed a barrier against the open Tethys ocean in the South (Ziegler 1990). Later, southward tilting of the South-German Block resulted in restriction and finally closure of marine seaways to the North. In turn, the South-German shelf opened to the Tethyan ocean in the South and a carbonate plattform with bedded limestones, massive sponge-microbialite, and coral reefs developed during successively rising sealevel. Most famous are the Solnhofen lithographic limestones, a blue-green algal laminite deposited in salinity-stratified lagoonal basins between declining sponge-microbialite reefs. In the Upper Tithonian, a change to sealevel fall interrupted sedimentation and lead to a first time interval of karstification in this region. During the following eustatic sealevel rise in the Cenomanian-Turonian, the area was partially flooded again from the South (Meyer 1981a, 1981b). Tertiary to present- 
day erosion of the gently SE dipping Mesozoic strata resulted in a typical cuesta landscape, with resistant carbonates (e. g., Muschelkalk, Weißjura) and sandstones (middle part of Keuper) forming escarpments, and less resistant clay- and siltstone formations (e. g., Schwarzjura) forming intermediate depressions. Intensive karstification caused the formation of numerous cave systems in the Franconian and Swabian Alb.

To the south, the "South-German Cuesta Landscape" passes into the broad plain of the Northern Alpine Molasse Basin. Here, sedimentation continued during the Upper Eocene to Miocene because of the high subsidence rates in front of the active Alpine Orogen. Temporary marine ingressions changed with fluviallacustrine systems. Synchronous to the deposition of the Upper Freshwater Molasse, an asteroid impact devastated central parts of the South German landscape and created the Nördlinger Ries crater. $150 \mathrm{~km}^{3}$ of Mesozoic cover sediments and Variscian basement rocks were partly melted, excavated, and ejected as a megabreccia and fall-out deposits (Stop 4) up to $40 \mathrm{~km}$ away from the impact centre. Despite of its desasterous effect on flora and fauna of this region, no mass extinction of species is associated with this impact. The crater was subsequently occupied by a closed, shallow soda lake with an individual-rich, species-poor fauna, lake-shore stromatolites and green-algal reefs (Stop 5), and sublacustrine microbial spring mounds (Stop O).

During Pleistocene times, Alpine glaciers advanced approximately to the latitude of Munich, with extended fluvial gravel plains in front of that. The South-German Cuesta Landscape remained in the periglacial realm. Here, eolian sands derived from the Keuper areas accumulated as sand dunes at the margin of the Franconian Alb, whereas loess deposition was widespread on Muschelkalk, Weißjura and Molasse areas. Since the end of the last glaciation about 11500 years ago, bicarbonate-rich groundwaters give rise to the deposition of calcareous tufa at springs (Stop 2) and along creeks (Stop 7).

\section{Stop 1: Sengenthal Quarry, Fränkische Alb}

Location: Geological Map of Bavaria $1: 25000$ Sheet 6734 Neumarkt i. d. Opf., east 4461 600, north 5455 600, abandonned quarry 500 m northwest of Sengenthal.

Geological Formation: Eisensandstein Formation to Dietfurt Formation.

Geological Age: Jurassic, ?Aalenian, Bajocian to Oxfordian, ca. 174 to 153 Ma.

Description: The abandonned quarry of a former concrete factory exposes a section from brown shallow-marine sandstones, to condensed iron-oolitic marlstones, and grey glauconitic claystones of the Middle Jurassic, overlain by a thick succession of 
white-grey bedded limestones with intercalated sponge-microbialite-mounds of the Upper Jurassic (Meyer \& Schmidt-Kaler 1983; Fig. 3, Pl. 1A). The quarry is famous for its extremely fossiliferous condensed iron oolites of the condensed iron-oolitic Garantianen-, Parkinsonien-, and Macrocephalen-beds, which contain wellpreserved ammonoids and other invertebrates (Callomon et al. 1987, Werner et al. 1992). The quarry is now maintained by a foundation as site for fossil collectors. Microbial deposits are present by two distinct types: (1) iron ooids and crusts of the Sengenthal-Formation ("Brown Jurassic $\gamma$ to $\varepsilon_{2}$ "), and (2) calcarous microbial crusts from the Dietfurt-Formation ("White Jurassic $\alpha$ and $\beta$ "). For recent revisions of stratigraphic terms of the South-German Jurassic see Bloos et al. (2005).

E

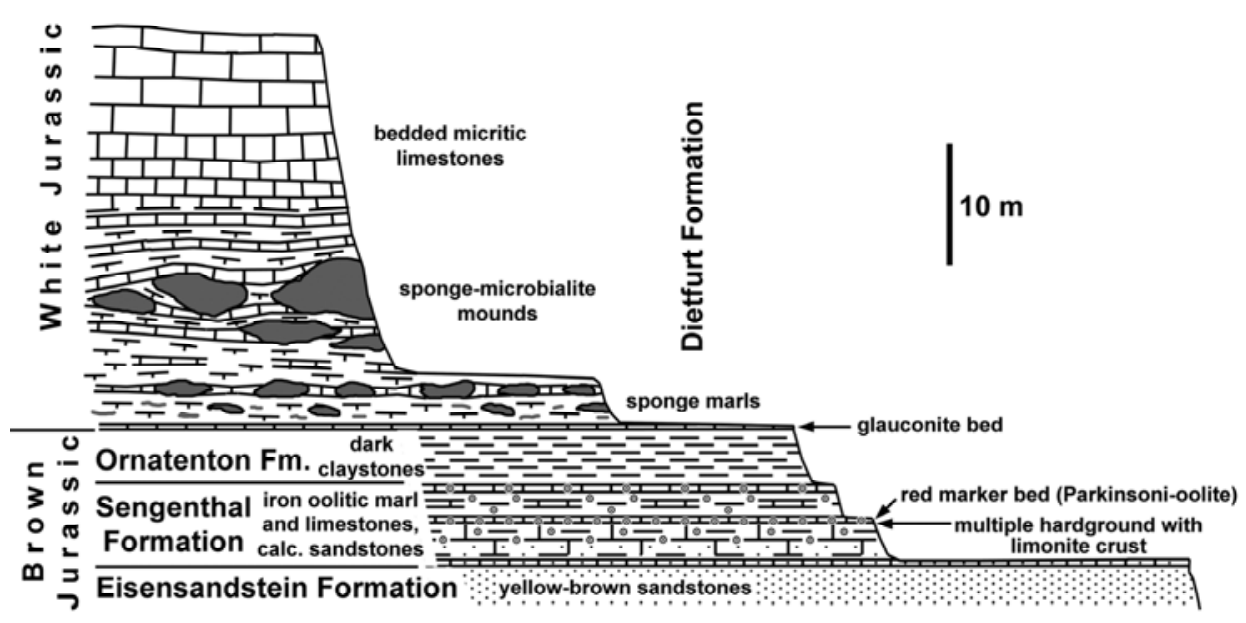

Fig. 3. Schematic section of the Sengenthal quarry, its formations and occurrences of microbialites.

Iron ooids from the Sengenthal-Formation are up to $2 \mathrm{~mm}$ in size, concentrically structured, and show radial shrinkage cracks (Pl. 1B). Mineralogically, they are composed of limonite, i. e. hydrated iron (III) oxide-hydroxides of varying composition. Millimetre-thin limonitic stromatolite crusts (Pl. 1C) which locally veneer hardground surfaces, i.e. syndepositionally lithified seafloor surfaces, are identical with regard to their microstructure (Arp 2001). Ooid is a collective term for spherical grains consisting of regular concentric lamellae. They can be composed of various carbonate, phosphate, iron or silicate minerals. The genesis these conspicous sedimentary grains is controversially discussed since Kalkowsky (1908), with models from inorganic precipitation in agitated water (e. g. Usdowski 1962, Davies et al. 1978) to biogenically forming within microbial mats (e. g. Dahanayake et al. 1985). 

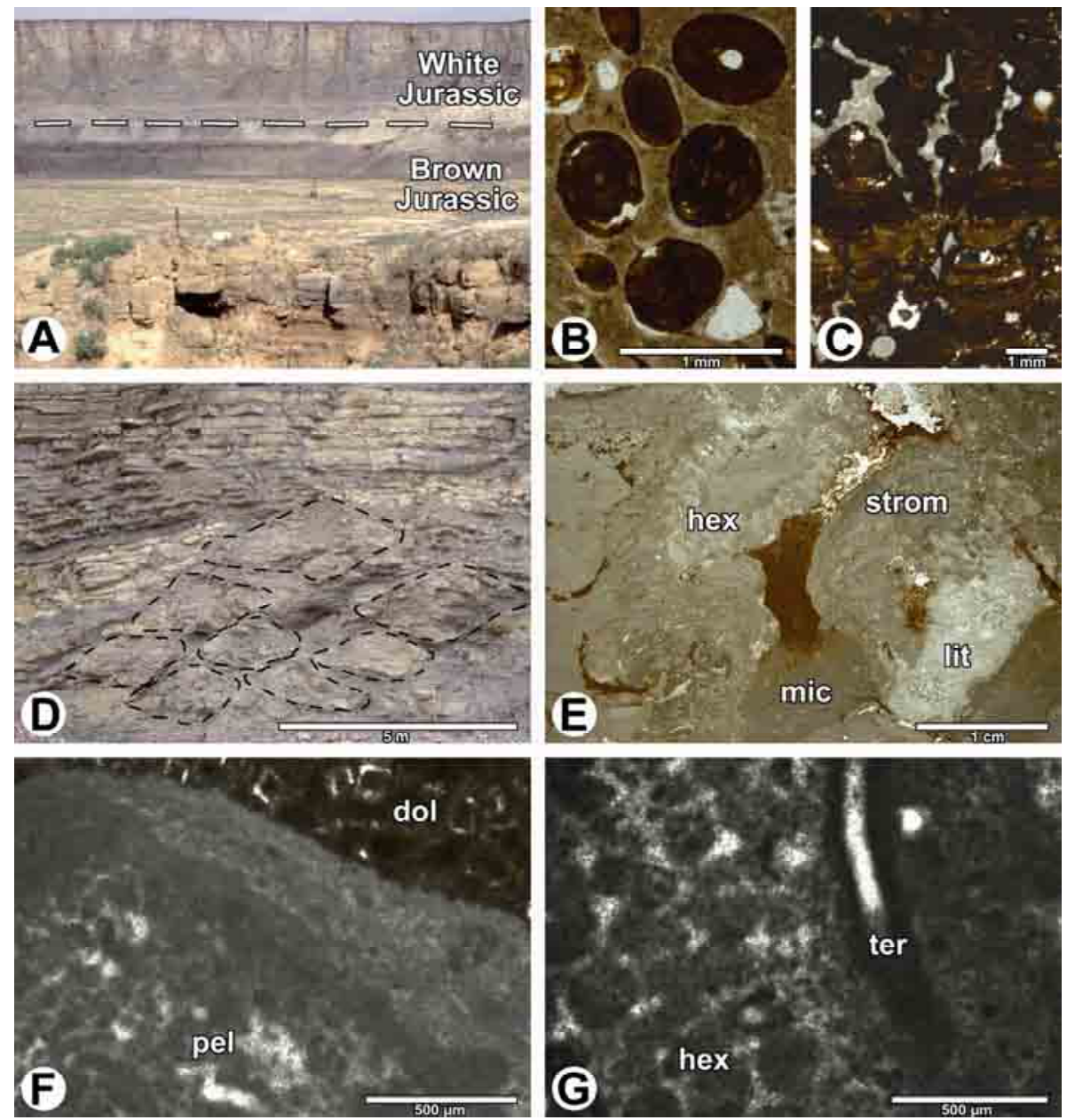

Plate 1. Microbialites of the Sengenthal and Dietfurt Formation, Middle and Upper Jurassic, Fränkische Alb. (A) Field view of the Sengenthal quarry exposing a section from the lower Brown Jurassic (Aalenian) to the lower White Jurassic (Oxfordian); (B) Iron ooids in marly micritic matrix. Sengenthal Formation, Upper Bajocian. Note limonite-filled shrinkage cracks in the cortices. Neumarkt; (C) Stromatolitic limonite crust of a multiple hardground of Upper Bajocian age. Upside down orientation reflects reworking and rotation of this limonite crust fragment. Neumarkt i. d. Opf.; (D) Meter-sized spongemicrobialite mounds from the Oxfordian Dietfurt Formation. Sengenthal; (E) Thin section of sponge-microbialite mound carbonate showing hexactinellid sponge (hex) and lithistid demosponge (lit), encrusted by stromatolitic micrite crusts (strom). Voids of the framework are filled by allochtonous micrite (mic), which is locally dolomitized; (F) Detail from (E) showing peloidal microstructure (pel) of the stromatolitic crusts. At the top late-diagenetic dolomite rhombs (dol) of sediment pocket between the sponge-microbialite framework are visible; (G) Microbial peloids within hexactinellid sponge (hex) and attached microcrystalline tube of Terebella (ter). sponge-microbialite mound of the Oxfordian Dietfurt Formation, Neumarkt i. d. Opf. 
Petrographic investigations suggest that limonite ooids do not form in highly agitated waters, but rather near the sediment-water interface at redox boundaries, and may have precursor minerals such as chamosite (Schellmann 1969). Presentday iron-ooid-forming environments are extremely rare, with only two case studies known. Modern chamositic ooids have been reported from shelf mud sediments off Cape Mala Pasqua, Venezuela (Kimberley 1994). Primary limonitic ooids have been discovered offshore the volcanic island Mahengetang, Indonesia (Heikoop et al. 1996). They are considered having formed by "chemical precipitation" on available grains on the seafloor, with $\mathrm{Fe}, \mathrm{Al}$ and $\mathrm{Si}$ from hydrothermal fluids rising up through the substrate, volcanic ash falls into shallow basins or rapid weathering of fresh volcanic rocks (Sturesson et al. 2000). However, no geomicrobiological studies have been carried out, and in analogy to carbonate ooids organic macromolecules and microbial activity can be expected to be involved in their formation. Indeed, Gerdes \& Krumbein (1987) already proposed an involvement of fungi in the formation of iron ooids.

Calcareous microbial crusts form substacial parts of sponge-microbialite-mounds mounds of the Dietfurt Formation, a predominantly bedded limestone formation which is exposed in the upper $30 \mathrm{~m}$ of the quarry. Flat, up to $100 \mathrm{~m}$ wide domes in the lower half of this formation reflect the amalgamation of numerous, metre-sized individual mounds (Fig. 3; Pl. 1D). This type of mound is widespread in the South German Upper Jurassic, from the Oxfordian to the lowermost Tithonian. Formerly, these mound have been termed sponge-algal buildups or bioherms (Flügel \& Steiger 1981, Dohmann 1991). Their framework is composed of hexactinellid sponges, the polyphyletic "lithistid" demosponges, and microbial crusts (Pl. 1E). These crusts are either macroscopically laminated (stromatolites), clotted (thrombolites) or structureless (leiolites). Thin sections show that they are microscopically composed of microbial peloids or dense microcrystalline carbonate $(\mathrm{Pl} .1 \mathrm{~F})$, with enclosed sessile foraminifera, tubes of sedentary worms (serpulids, Terebella; Pl. 1G), scattered bryozoans and ostreid bivalves (Nitzopoulos 1974). Sponge borings as well as incrusting organisms indicate that these mounds were initially indurated. The syndepositional relief of the Sengenthal mounds was probably low, but differential compaction later caused a secondary steepening of their flanks.

Indeed, there has been a long controversial discussion on the microorganisms and mechanisms involved in the formation of microbial crusts of these "sponge-algalmounds", and consequently their bathymetric position. For the Sengenthal mounds, a depositional depth between 50 and $150 \mathrm{~m}$ has been proposed (Dohmann 1991), i. e., a wide range reflecting the discrepancy between the lack of typical shallow water organisms in this lower part of the White Jurassic (calcified cyanobacteria, dasycladacean algae, hermatypic coral) and the supposed phototrophic, cyanobacterial nature of the microbialite crusts (Wagenplast 1972, Nitzopoulos 1974). The latter interpretation was based on the columnar upward growth of some of the crusts, and their restriction to the upper side of platy sponges. However, filament-like structures which were interepreted as algal filament traces 
(Flügel \& Steiger 1981) are now considered as sponge spicules (Keupp et al. 1993) and unequivoval calcifying cyanobacteria (such as Cayeuxia) occur only in younger parts of the Upper Jurassic Weißjura-Group of Franconia (e. g., Flügel 1977). Indeed, sedimentary features of shallow water (resedimentation, grainstones, ooids; e. g., Wirsing \& Koch 1986) only occur farther up in the succession, in the Middle and Upper Kimmeridgian. Stable carbon and oxygen isotope values of microbialite crust appear to be in equilibrium with Jurassic seawater (Keupp et al. 1993, Leinfelder et al. 1993) so that a strong impact of either photosynthesis, methanogenesis or methanotrophy appears unlikely. The microbialites are poor in organic carbon and hydrocarbon biomarkers were extracted only in very low concentrations. These indicate the former presence of aerobic and anaerobic Bacteria and Archaea and detrital influx from higher plants (Keupp et al. 1993, 1996). Peloidal precipitates within siliceous sponge are possibly related to bacterial ammonification during decay of the sponge tissue ("Verwesungskalk", Fritz 1958, Hiller 1964) and the phytane/pristane relationship indicate their formation under anoxic conditions (Keupp et al. 1993). However, no evidence for the former presence of cyanobacteria was found (Keupp et al. 1993, 1996) and a further specification of the microbial communities failed. In conclusion, the sponge-microbialite mounds likely were independent from photic conditions and could form in a wide bathymetric range (Keupp et al. 1996, Leinfelder et al. 1996).

\section{Stop 2: "Steinerne Rinne" at Erasbach, Fränkische Alb}

Location: Geological Map of Bavaria $1: 25000$ Sheet 6834 Berching, east 4457 750, north 5444 250, $1.3 \mathrm{~km}$ south of the village Erasbach.

Geological Formation: Present-day tufa deposits.

Geological Age: Recent, less than 70 years.

Description: Calcareous tufa deposits of springs and creeks are common in karst regions such as the Franconian and Swabian Alb (e. g., Stirn 1964, Grüninger 1965). Karstification driven by soil-derived $\mathrm{CO}_{2}$ leads to the formation of $\mathrm{Ca}^{2+}$ rich, high- $\mathrm{pCO}_{2}$-groundwaters which rapidly degas when the aquifer discharges to the subaerial environment. Tufa (or meteogene travertine; Pentecost 2005) refers to porous, poorly stratified, usually friable carbonate deposits which form at nonthermal springs and creeks (Ford 1989, Riding 1991). Low-Mg-calcite is the usually main mineral component (e.g., Irion \& Müller 1968) as a result of low $\mathrm{Mg}^{2+} / \mathrm{Ca}^{2+}$ ratios of karst waters. Steinerne Rinnen ("stony runnels") are one of the most striking and amazing tufa deposits. In contrast to other creeks, tufa deposition along the edge of the water course leads to vertical growth and formation of a self-built canal, with the water flowing in narrow, centimetre-wide course on its top (Pl. 2A- 
B). Their central channel is floored by laminated tufa stromatolite crust, bordered by moss tufa dams along both sides of the water. Rapid upward growth of the later seems to maintain the morphological growth form (Glassl \& Schieber 1990). It remains, however, poorly understood why a few karst water creeks develope selfbuilt tufa canals, whereas most others do form sheet-like deposits or cascades.

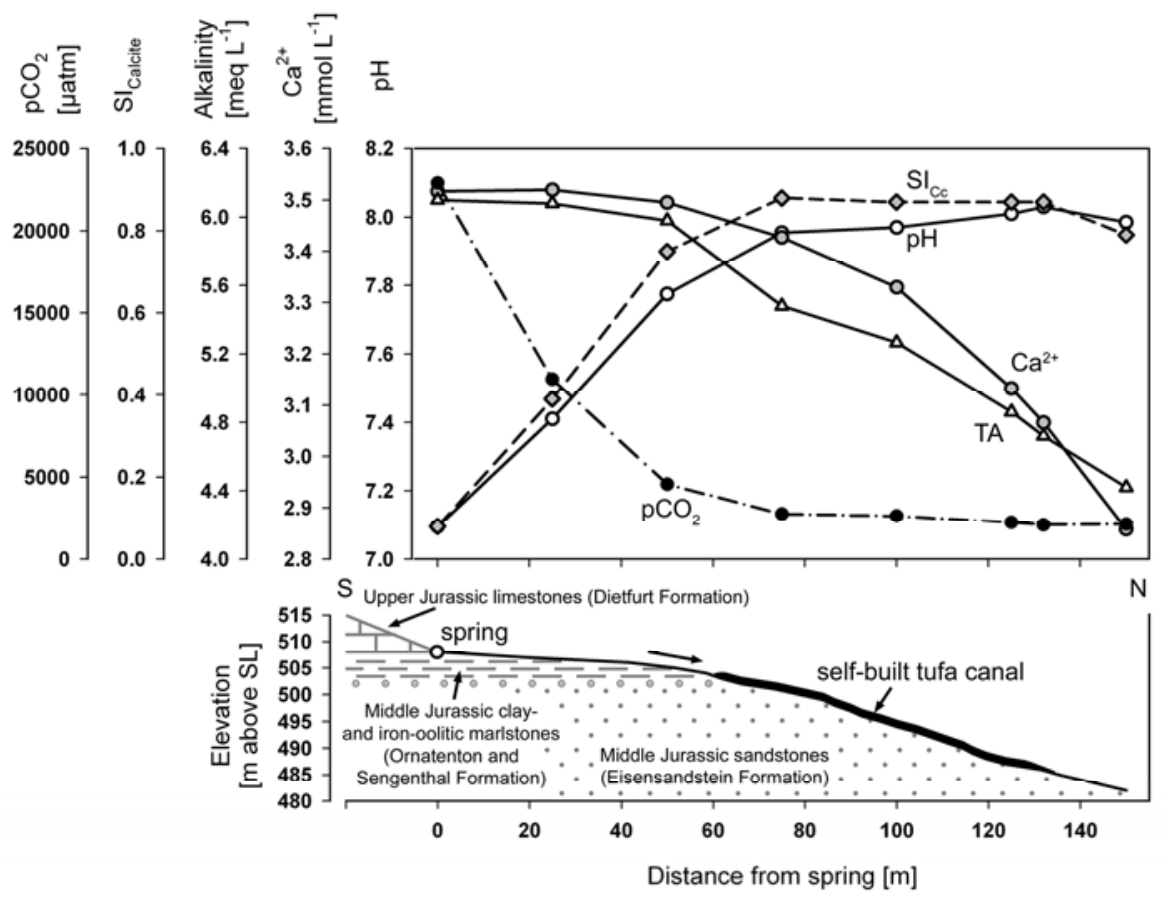

Fig. 4. Hydrochemical evolution along the flowpath of the Erasbach self-built tufa canal, $13^{\text {th }}$ of October 2001. Data courtesy of Andreas Reimer.

The spring of the Steinerne Rinne of Erasbach (Pl. 2C) discharges from the base of the Weißjura-aquifer, where thick Upper Jurassic limestones (here: "Weißjura $\alpha$ and $\beta "$, Dietfurt Formation) are underlain by a few metres of clays of the Middle Jurassic Ornatenton Formation ("Braunjura $\varepsilon_{3}$ and $\zeta^{\prime \prime}$ ) (Meyer \& Schmidt-Kaler 1983, Baier 2002; Fig. 4). It is one of the most important spring horizons of the Franconian Alb (Fränkische Alb). The self-built tufa canal of Erasbach has a total length of approximately $80 \mathrm{~m}$ and attains a maximum heigth of $77 \mathrm{~cm}$ (Baier 2002), and is now protected as a nature site. Only 12 localities of these very fragile ecosystems are known in Bavaria (Glassl \& Schieber 1990). 

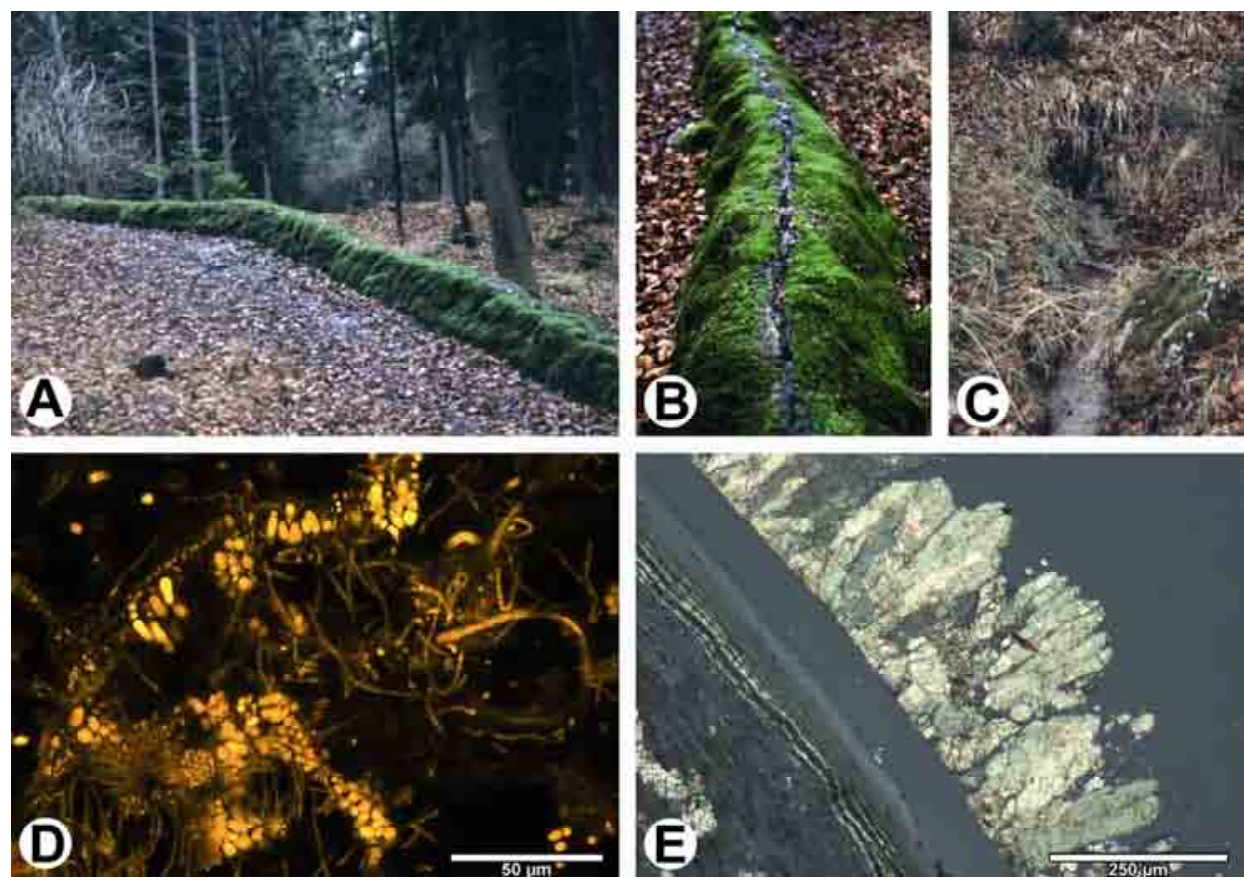

Plate 2. Present-day tufa deposits of the Steinerne Rinne at Erasbach, Fränkische Alb. (A) Field view of the self-built tufa canal; (B) View on top of the middle part showing the centimetre-wide channel; (C) Spring orifice at the boundary of Ornatenton claystones to Weißjura limestones; (D) Laserscanning micrograph of calcite-encrusted coccoid and filamentous cyanobacteria at the transition of moss tufa to stromatolitic tufa of the central flow path (ex $488 \mathrm{~nm}, 633 \mathrm{~nm}$, em 565-615 nm, 639-704 nm); (E) Calcite cement overgrowth on moss stem surface from the tufa canal rim. Normarski optics.

Biofilms of tufa-forming creeks are composed of cyanobacteria, diatoms and nonphototrophic bacteria. These biofilms cover the stream bed as well as older parts of moss plants (e.g., Cratoneuron commutatum). Most abundant are filamous cyanobacteria of Phormidium and Lyngbya morphotypes (Pl. 2D) showing calcite-encrusted filaments. Recent investigations from the nearby Deinschwanger Creek demonstrate that the Phormidium-type isolates phylogenetically are closely related to Phormidium autumnale strains [SAG 78.79], but possibly comprise several closely related species (Mohr et al. 2006). Isolates characterized by thicker, Lyngbya-type filaments turned out to be most closely related to strains Tychonema bourrellyi CCAP 1459/11B [from Loughgall, Northern Ireland] and Oscillatoria borneti SAG 4.82 [from Lake Mjøsa, Norway]. In addition, representatives of Leptolyngya, Plectonema, Microcoleus and Chamaesiphon were detected. The latter is surprisingly widespread and has already been identified morphologically in thin sections (Arp et al. 2001). Furthermore, endolithic cyanobacteria of the Hyella morphotype occur on limestone clasts but also within the tufa stromatolites. Spring site algal communities, 
which remains uncalcified, significantly differ from communities downstream by the lack of the Phormidium- and Lyngbya-type representatives mentioned above. This may directly reflect high- $\mathrm{pCO}_{2}$ conditions and lower $\mathrm{pH}$ favouring growth of other cyanobacterial taxa.

Recent investigations of biofilms of a tufa-forming creek in Northern Germany revealed a surprisingly diverse non-phototrophic prokaryotic community (Cousin et al. 2007) associated with the cyanobacteria and diatoms. While a part of the creek water bacteria can be derived from adjacent soil, most of the biofilm prokaryotes appear to be biofilm-specific (Cousin et al. 2007). Among them, Firmicutes, Proteobacteria, Actinobacteria, and Bacteriodetes appear especially abundant (Fig. 5). Some representatives of these groups are capable of digesting high-molecularweight organic compounds, therefore likely play a significant role in the degradation of diatom and cyanobacterial sheath exopolymers. However, their potential impact on calcification remains to be investigated.

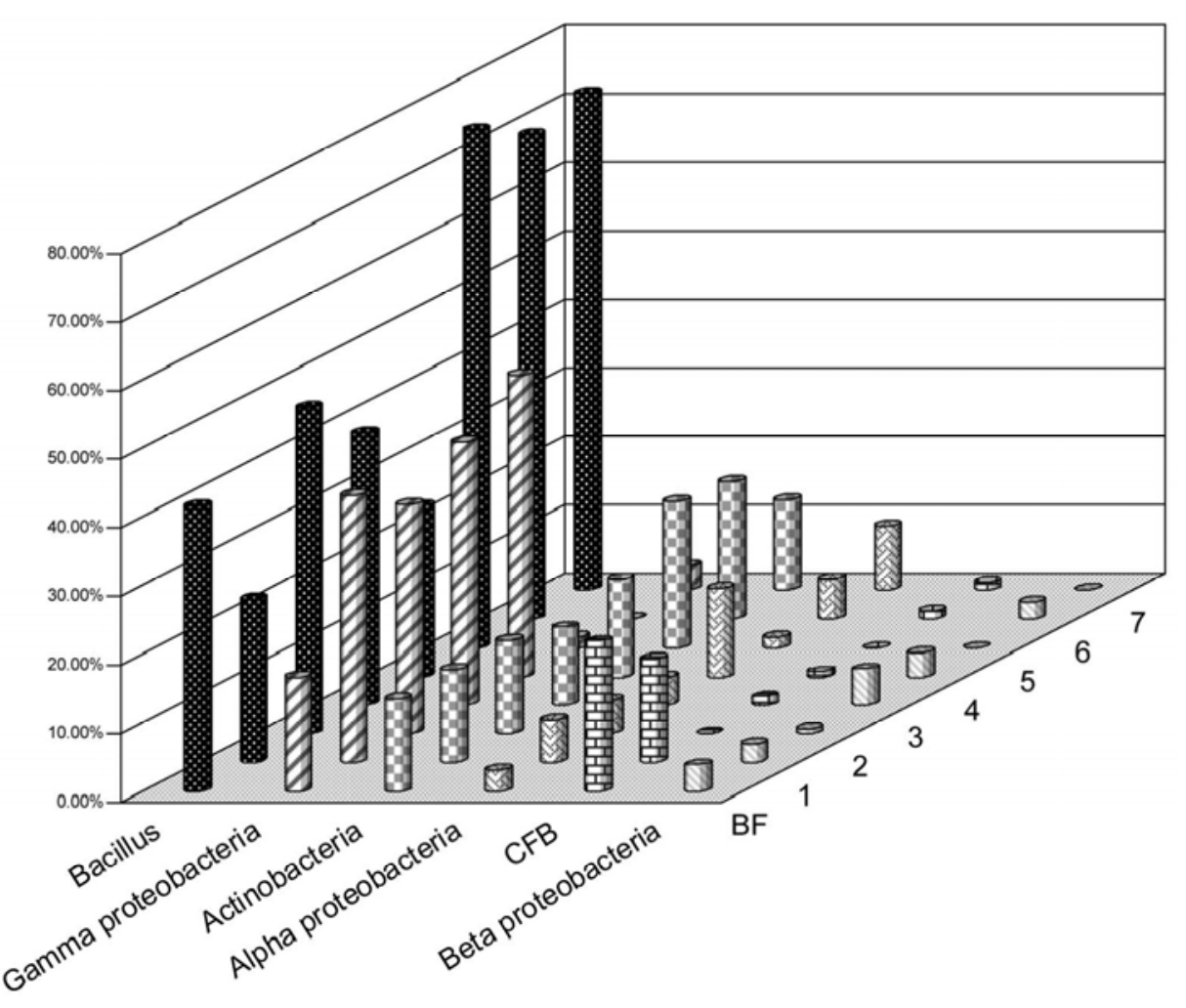

Fig. 5. Distribution of bacterial isolates by Phylum in a tufa biofilm (BF) and seven tufa carbonate layers (1-7) below. Westerhöfer Creek, W of Harz Mountains. From Cousin et al. (2007). 


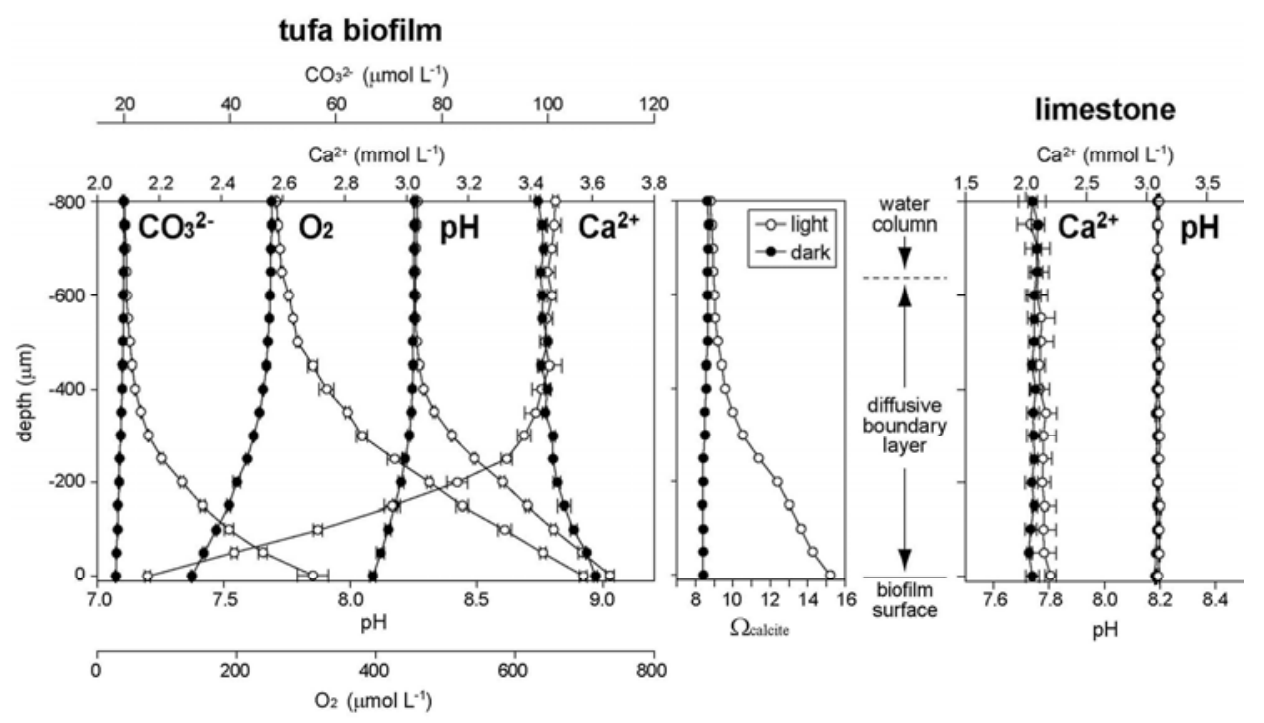

Fig. 6. Ex situ microprofiles of a tufa biofilm $\left(\mathrm{pH}, \mathrm{O}_{2}, \mathrm{Ca}^{2+}\right.$ and $\left.\mathrm{CO}_{3}{ }^{2-}\right)$ and biofilm-free limestone substrate $\left(\mathrm{pH}\right.$ and $\mathrm{Ca}^{2+}$ ) obtained under illumination (open circles) and darkness (closed circles), respectively. Calcite saturation state $(\Omega)$ calculated from $\mathrm{Ca}^{2+}$ and $\mathrm{CO}_{3}{ }^{2-}$ profiles is also shown. From Shiraishi et al. (2008a).

Between the seasons, the tufa stromatolite biofilm communities significantly change as a function of light intensities and, probably less important, temperatures. Summer-autumn biofilms show densely arranged Phormidium filaments and form thin dense carbonate layers composed of microcrystalline calcite. On the other hand, winter-spring biofilms are characterized by abundant diatoms and loosely arranged Phormidium filaments, thereby forming thicker, porous carbonate layers composed of microspar (Arp et al. 2001). As a result, tufa stromatolites display a clear seasonal lamination, which is also seen in the stable oxygen isotope composition of the laminae (Shiraishi et al. 2008b).

In general, tufa deposition is commonly regarded as essentially driven by physicochemical $\mathrm{CO}_{2}$-degassing, with a varying contribution of photosynthetic $\mathrm{CO}_{2-}$ removal. Indeed, hydrochemical data of the macroenvironment support this view (Fig. 4): At Erasbach, a rapid decrease in $\mathrm{pCO}_{2}$ from $23000 \mu \mathrm{atm}$ to $2100 \mu \mathrm{atm}$ is coupled with an increase of $\mathrm{pH}$ from 7.1 at the spring site to maximum values of 8.1. This $\mathrm{pH}$ rise results in an increase of calcite supersaturation from initially 1 fold $\left(\mathrm{SI}_{\mathrm{Cc}}=0.08\right)$ at the spring to 6 -fold $\left(\mathrm{SI}_{\mathrm{Cc}}=0.78\right)$ at about $60 \mathrm{~m}$ from the spring, where the tufa runnel starts. At this point, calcium concentration and total alkalinity begin to decrease and calcite supersaturation attains a maximum plateau of 7.5-fold $\left(\mathrm{SI}_{\mathrm{Cc}}=0.88\right)$. Finally, ongoing calcite precipitation leads to a decrease in calcite supersaturation at approximately $150 \mathrm{~m}$ distance from spring, where tufa 
formation stops. This chemical evolution of creek waters is identical to observations at other tufa-forming sites (e. g., Westerhöfer Creek, Shiraishi et al. 2008a).

However, recent microsensor measurements in situ in tufa-forming creeks and ex situ in laboratory experiments demonstrate a clear coupling of photosynthesisinduced $\mathrm{pH}$ rise and $\mathrm{Ca}^{2+}$ removal under daylight (Fig. 6). In turn, a $\mathrm{pH}$ decrease coupled with a minor $\mathrm{Ca}^{2+}$ release occurred at darkness (Bissett et al. 2008, Shiraishi et al. 2008a). This indicates a diurnal photosynthesis-controlled biofilm calcification causes the formation of tufa stromatolites, but not inorganic, physicochemical biofilm impregnation. It is noteworthy that mass balance calculations on basis of these microsensor profiles show that only 10 to $20 \%$ of the $\mathrm{Ca}^{2+}$ lost from the creeks waters are removed via these cyanobacteria-rich biofilms. Therefore, it appears that in parallel to the photosynthetically-induced tufa stromatolite growth, physicochemically-driven precipitation occurs in the water column, on moss surfaces and as cement overgrowth on biofilm-free areas (Shiraishi et al. 2008b). Indeed, sections of moss tufa from the canal rim demonstrate an intensive calcite cementation (Pl. 2 E), with only patchy biofilm development.

\section{Stop 3: Quarry Haardt and Bürgermeister-Müller-Museum Solnhofen, Fränkische Alb}

Location: Topographic Map of Bavaria 1:25000 Sheet 7132 Dollnstein, east 4424 000, north $5417500,2 \mathrm{~km}$ west of the village Solnhofen.

Geological Formation: Solnhofen Formation.

Geological Age: Upper Jurassic, Tithonian, $145 \mathrm{Ma}$.

Description: The lithographic limestones ("Plattenkalke") of the Solnhofen Formation represent one of the most famous Fossillagerstätten worldwide. This is largely because of the discovery of the oldest known bird Archaeopteryx H. v. Meyer 1861, a transitional species ("missing link") which played an important role in the discussion of Darwin's theory of evolution. However, numerous other well-preserved and articulated vertebrate fossils, decapod crustaceans, insects, and even jellyfish have been found. In total, more than 750 species of animals and plants are known from the Solnhofen lithographic limestone (Wellnhofer 2008).

The Solnhofen Formation has been deposited in subbasins ("Wannen") between declining sponge-microbialite mounds and, farther southeast, coral-sponge reefs. This 40-90 m thick formation typically consists of an alternation of $\mathrm{cm}-\mathrm{dm}$ thick pure micrite beds with lamination ("Flinze") and $\mathrm{mm}-\mathrm{cm}$ thick marlstone interlayers ("Fäulen"). Both are poor in $\mathrm{C}_{\text {org }}$, with concentrations less than $0.9 \%$ (Hückel 1974). In addition, large slumped beds (“Krumme Lagen”), which pro- 
bably were induced by seismic events (Krumbeck 1928), can be traced across subbasins (Pl. 3A). Only a few subbasins (Paintener Wanne) show graded beds with fossil debris derived from adjacent reefs. The section of the quarry Haardt exposes very thin, platy lithographic limestones of the Upper Solnhofen Formation inclusive a slump bed at its top (Röper \& Rothgaenger 1998).
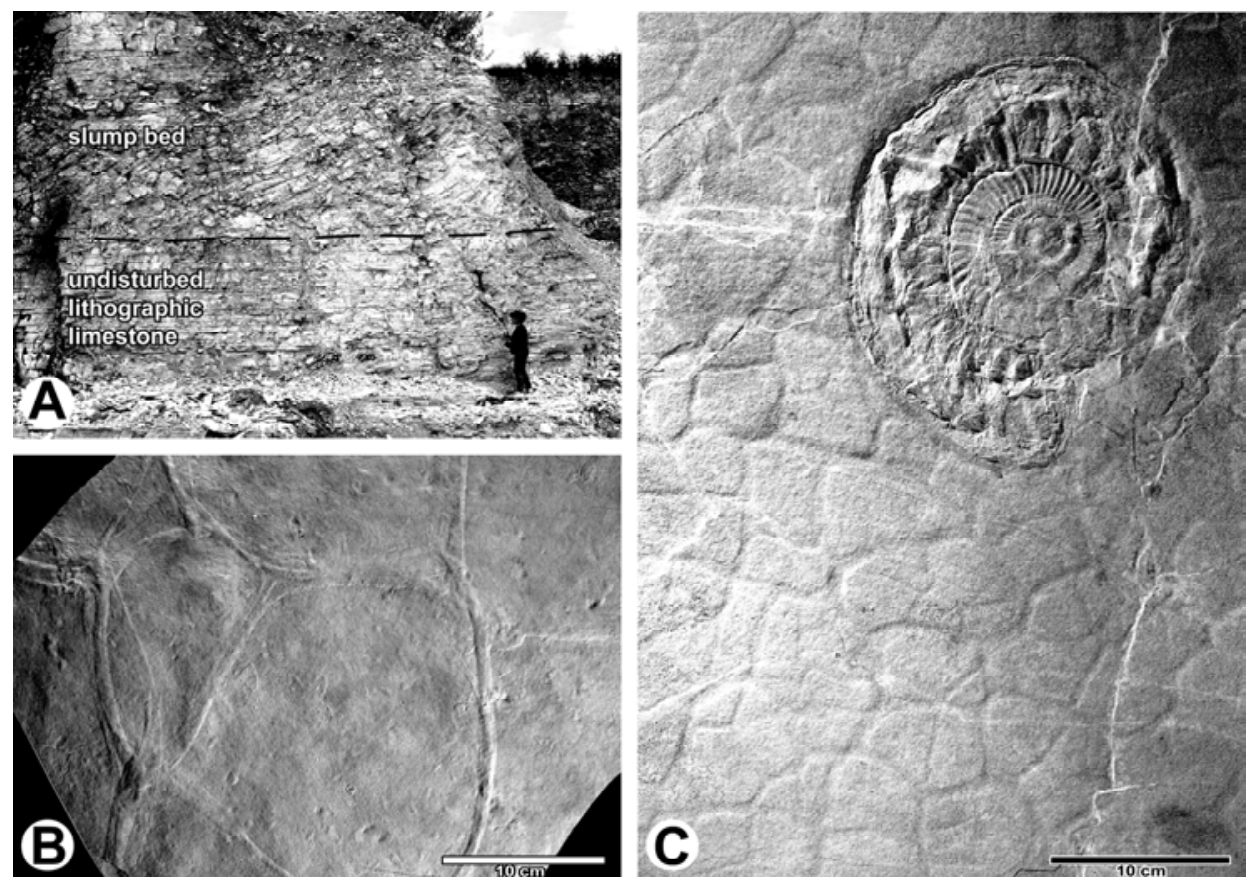

Plate 3. Microbial structures of Upper Jurassic lithographic limestones, Fränkische Alb. (A) Field view of Solnhofen Formation, with alternation of platy micrite beds and marly interlayers, overlain by a slumped bed. Wintershof; (B) Polygonal petee structures on bedding plane of the Upper Kimmeridgian lithographic limestone of Brunn near Regensburg. Sample courtesy of Günter Schweigert; (C) Indeterminate perisphinctid ammonite on bedding plane with smooth polygonal structures from the same locality. Bürgermeister-MüllerMuseum Solnhofen.

The genesis and palaeoenvironment of the lithographic limestones have been discussed controversially for many decades. Chemical precipitation of micrite due to evaporation on tidal flat (Schwerdtschlager 1919), coccolith ooze in shallow (Gümbel 1891) or deep lagoons (Buisonje 1972), and deposition of fine-grained turbidites derived from adjacent reefs (Walther 1904, Straaten 1971) are only three of the many models that have been proposed for the formation of this exceptional sediment. However, in a detailed SEM investigation, Keupp (1977) revealed that hollow micrite spheres with an outer diameter of 8-20 $\mu \mathrm{m}$ form major parts of the 
laminated micrite beds, whereas coccoliths are restricted to the marly interlayers. Based on that, Keupp (1977) developed following model of lithographic limestone formation, a model that is still widely accepted (Fig. 7):

(1) Stagnation and evaporation leads to salinity stratification of the water column, oxygen depletion and death of temporary foraminiferal benthos and nectonic organisms. High salinities and low oxygen concentrations reduced bacterial decay of the carcasses. Instead, blooms of coccoid cyanobacteria at the lagoon bottom veneer the carcasses and induce microcrystalline calcite precipitation. This leads to an enhanced preservation of the carcasses and causes the formation of micrite layer ("Flinz").

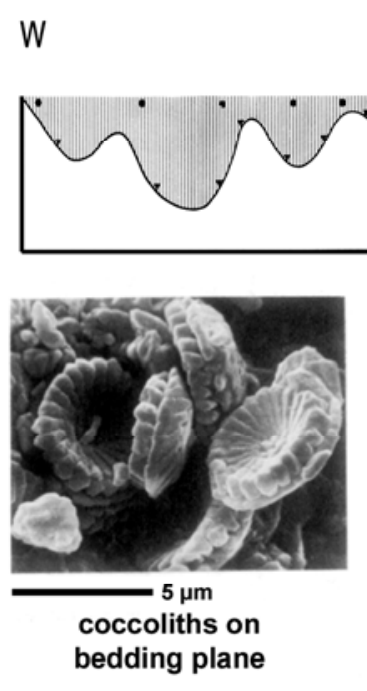

open marine
conditions

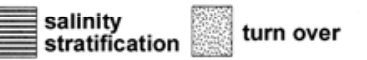

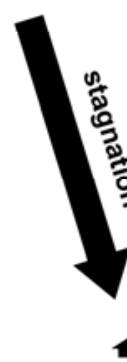
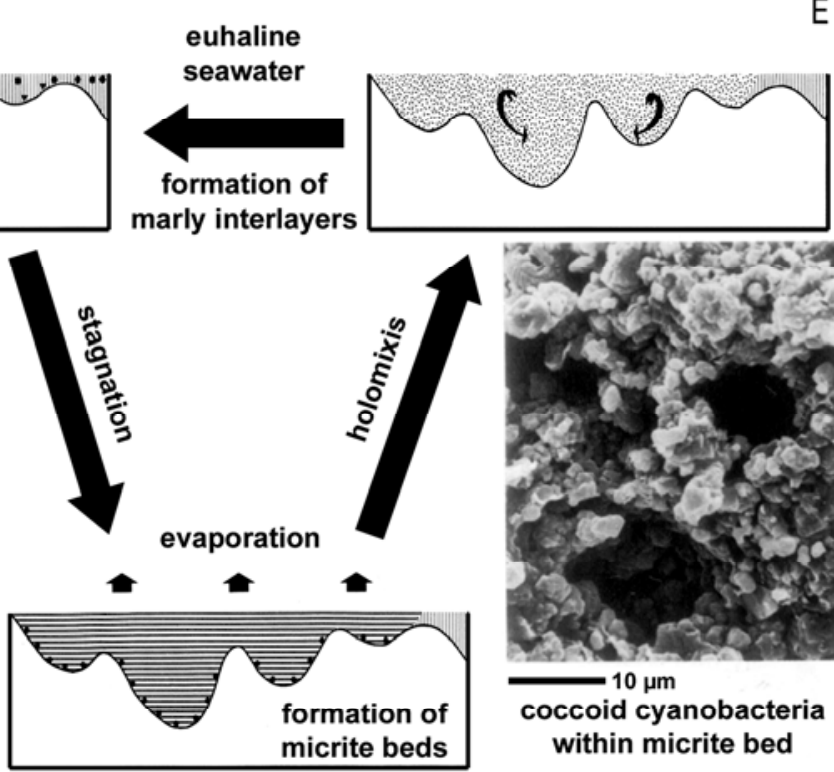

E

\section{marly interlayers} micrite beds

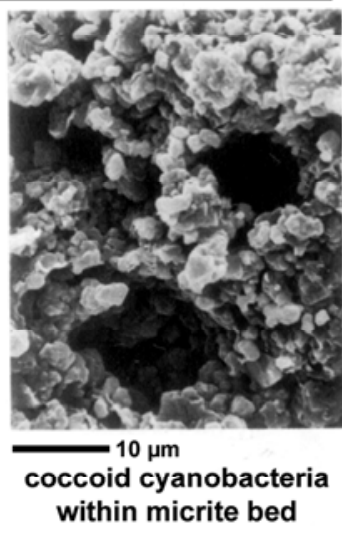

Fig. 7. Model of the formation of lithographic limestone in the Upper Jurassic lagoon of Solnhofen. From Keupp (1977). 
(2) Monsoon or episodic storm events caused influx of open seawater from the south, as well as influx of clay minerals from adjacent terrestrial areas. As a result, marly interlayers formed ("Fäulen"). At that time, planctonic (coccolithophorids) as well as nectonic organisms (e. g. fish, ammonoids) were introduced into the lagoon. Holomixis lead to temporary normal-marine conditions in the lagoonal water column and development of a short-term foraminiferal benthos at the sediment surface. Later, the onset of stagnation and evaporation initiate a new cycle of micrite layer formation. Different taphonomy of fish ("soft tissue preservation" vs "fishbone preservation") between subbasins may reflect differences in the time necessary for the establishment of salinity stratification and cyanobacterial biofilms (Keupp 1977).

From view point of this model, one may regard the Solnhofen lithographic limestone as one large stromatolite, because it is macroscopically laminated and formed by benthic microbial communities. However, it is not totally clear that the coccoid cyanobacteria found in SEM studies and the micrite precipitation were benthic. Indeed, upward growing morphologies or fenestral fabrics characteristic of many stromatolites lack. Nonetheless, some lithographic limestone occurrences (Brunn, Nusplingen, Wattendorf, Cerin), all of them slightly older (Upper Kimmeridgian) and not fully identical to the Solnhofen lithographic limestone, provide morphological evidence for former microbial mats covering the sediments surface (Bernier et al. 1991, Röper et al. 1996, Fürsich et al. 2007). Examples of polygonal network structures, which are considered to reflect former microbial mats, are provided in Pl. 3B-C. So-called petee structures shown in Pl. 3A are characterized by a padshaped relief, in contrast to mud cracks, and may result from retraction of microbial mats (Bernier et al. 1991). There is no clear present-day analogue known for the Solnhofen lithographic limestone, but the Kimmeridgian lithographic limestones may have their counterpart in the lagoon of Aldabra (Gaillard et al. 1994).

The excellent preservation of vertebrate and other fossils should not hide the fact that most fossils are generally rare in the Solnhofen lithographic limestone. A rich collection of them and corresponding explanatory notes are displayed in the Bürgermeister-Müller-Museum downtown Solnhofen in the Altmühl valley, among them the original "Solnhofen Archaeopteryx specimen" as well as the ninth specimen of Archaeopteryx, discovered in 1997 (Wellnhofer \& Röper 2005).

\section{Stop 4: Quarry Aumühle northeast of Oettingen i. Bay., Ries crater}

Location: Topographic Map of Bavaria $1: 25000$ Sheet 7029 Oettingen i. Bay., east 4399 800, north $5426780,2.5 \mathrm{~km}$ northeast of Oettingen.

Geological Formation: Ries-Impact deposits. 


\section{Geological Age: Miocene, 14.8 Ma.}

Description: The suevite quarry Aumühle (Fig. 8) is a must for every geological field to the Ries impact crater. This crater, which subsequently served for $500 \mathrm{ka}$ as an excellent habitat for the growth of lacustrine microbialites, formed $14.8 \mathrm{Ma}$ ago by the hypervelocity impact of a $1-\mathrm{km}$-sized stony asteroid. This asteroid penetrated about $600 \mathrm{~m}$ Mesozoic sedimentary cover of the Franconian-Swabian Alb into the Variscian crystalline basement (gneiss, granites and metabasites of the Moldanubicum). After the vaporization of the projectile and the excavation of a transient crater with a depth of $4.5 \mathrm{~km}$, gravity caused collapse of the crater rim and uplift of the its floor. The final result was a hydrologically closed, complex impact structure almost $25 \mathrm{~km}$ in diameter, subdivided by a ring structure in a central crater and a marginal megablock zone (Reich \& Horrix 1955, Chao 1977, Ernstson \& Pohl 1977, Stöffler 1977). The ejecta blanket as well as the crater floor was covered by a blanket of the impact-melt bearing crystalline breccia. Today, large parts of the fallout suevite outside the crater are eroded (see Hüttner \& Schmidt-Kaler 1999). As a consequence of the gravitational collapse, the later Ries crater lake had a high surface to depth ratio, if compared to lakes in simple craters.

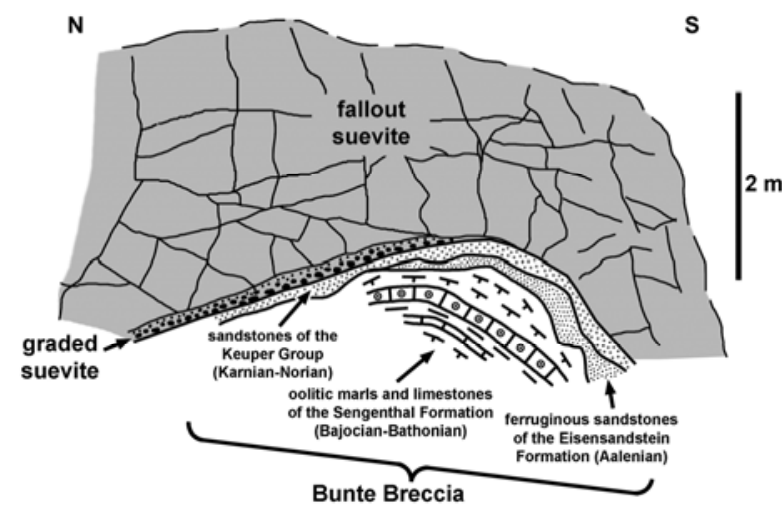

Fig. 8. Schematic drawing of a quarry face at the entrance to the Aumühle quarry with ejecta deposits (Bunte Breccie) overlain by suevite, an impact-melt bearing crystalline rock breccia that has been considered by geologists prior to 1961 to be of volcanic origin.

The Aumühle quarry is located in the marginal megablock zone of the crater near the tectonic rim. The outcrop exposes the contact between the "Bunte Breccie", an ejecta deposit largely composed of clasts and blocks of the Triassic-Jurassic sedimentary sequence of this area, and the suevite, an impact-melt-bearing breccia with microscopic inclusions of the high-pressure minerals phases stishovit, coesit, diamond, and silicon carbide (Shoemaker \& Chao 1961, Chao \& Littler 1963, Hüttner 1969, 1977, Hough et al. 1995). Most noticable are cm to dm-sized black vesicular glass bombs, besides of highly-shocked crystalline rock fragments. Below the massive fallout suevite a graded unit can be seen at Aumühle (Fig. 8). The exact 
mode of deposition of the suevite is still under discussion, but may have been either lateral, basal transport comparable to a volcanic pyroclastic flow, or fall out of a collapsing ejecta plume, or a combination of both (Meyer et al. 2007).

\section{Stop 5: Hainsfarth quarry at the Büschelberg, Ries crater}

Location: Topographic Map of Bavaria $1: 25000$ Sheet 7029 Oettingen i.Bay., east 4400 050, north 5425000 , abandonned quarry now used as a soccer field, immediately southeast of Hainsfarth.

Geological Formation: Dolomitic algal bioherms of the Ries crater lake sediments.

Geological Age: Miocene, ca. 14 Ma.

Description: The abandonned quarry of Hainsfarth provides the largest and most instructive outcrop of lake shore sediments of the Ries crater lake (Riding 1979). After its development from an initial playa lake to a permanent soda lake, which successively turned into a halite lake, most of the Ries lake shorelines were occupied by cyanobacterial and green-algal bioherms (Figs. 9-10). These are composed of green algal dolomites and cyanobacterial stromatolites (Reis 1926, Wolff \& Füchtbauer 1976, Bolten 1977, Riding 1979, Arp 1995b), and are commonly veneered by rigid, laminated carbonate crusts to form nodules, cones and compound cones (Fig. 11).

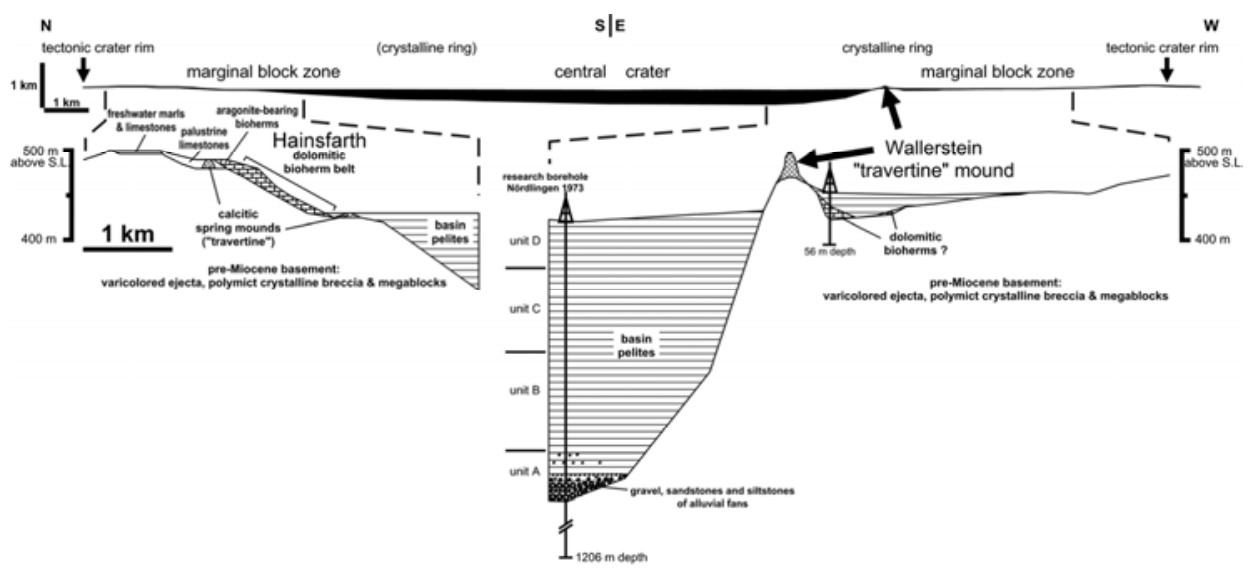

Fig. 9. Cross-section of the Ries crater lake basin showing major facies units. Upper part shows a general section of the shallow basin, divided by a "crystalline ring" into a central crater and a marginal block zone. Lower part shows two detailed, exaggerated vertical scale sections of the marginal carbonate sediment cover with the location of the Wallerstein "travertine" mound and the Hainsfarth algal bioherm belt. From Pache et al. (2001). 


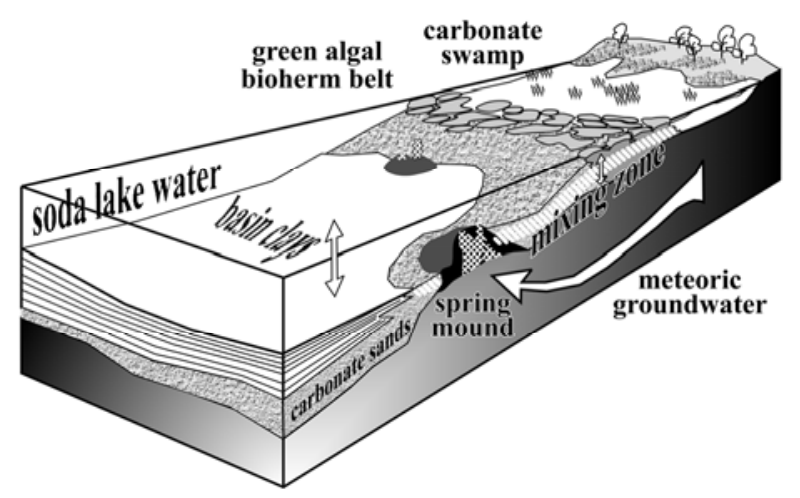

Fig. 10. Reconstruction of the northern Ries lake margin with the distribution of major facies zones. From Arp (1995b).

Associated carbonate sands are largely composed of ostracods (Standesia risgoviensis), mesogastropods (Hydrobia trochulus), ooids, peloids and intraclasts. Locally, pockets of palustrine limestones with abundant pulmonate gastropods of the species Cepaea sylvestrina are common. Exceptional findings are thin-walled foraminifera and a dolomitized millipede (Arp 1995a, 1995b). The total bioherm succession extends over an elevation difference of $80 \mathrm{~m}$, but the thickness of carbonate deposits at one place rarely exceeds $10 \mathrm{~m}$. Temporarily, the algal bioherms formed a continuous "reef belt", with palustrine carbonates of a carbonate swamp behind (Fig. 10).

The major bioherm constituent is a fossil green alga closely resembling the modern Cladophora (Reis 1926, Wolff \& Füchtbauer 1976, Riding 1979). The fossil, termed Cladophorites incrustatus (Ludwig) Reis is composed of branching, erect tubes of 50$140 \mu \mathrm{m}$ inner diameter and dolomicritic walls of 5-15 $\mu \mathrm{m}$ thickness. Pure Cladophorites-framestones (Pl. 4A) exhibit a rhythmic growth pattern due to an alternation of erect tubes and branched, more densely arranged and tangled tubes, while high particle influx results in irregular Cladophorites bafflestones (Pl. 4B). By contrast, charophytes are very rare in the algal bioherms, and occur preferentially near tributaries of the Ries lake (Pl. 4C).

Sinter-veneered Cladophorites-bafflestones probably formed by high-Mg calcitic impregnation of biofilms upon green algal filaments and baffling of allochthonous particles between the resulting tubes within the wave-exposed eulittoral. The laminated sinter crusts, characterized by pendent morphologies, are interpreted to be of lacustrine-vadose origin. Prolonged eu- to supralittoral conditions are reflected by non-skeletal stromatolites and skeletal stromatolites. On the other hand, intervals of lake level highstand and shallow sublittoral conditions allowed undisturbed, rhythmic growth of Cladophorites-framestones. These Cladophorites growth rhythms are considered to reflect seasonal rhythms and suggest average annual accumulations of $4 \mathrm{~mm}$ for framestones. 


\section{$\boldsymbol{\infty}$}
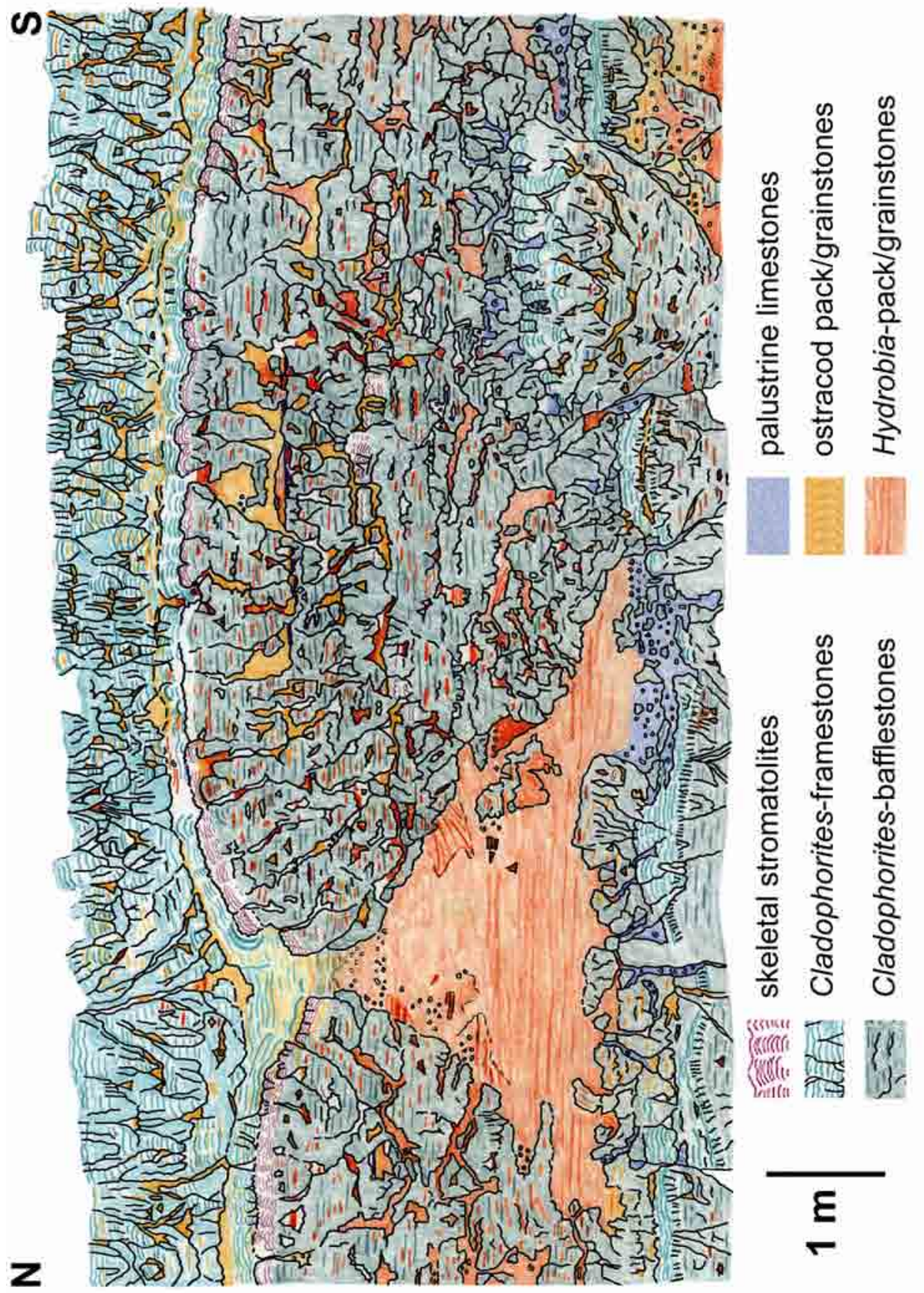

Fig. 11. Facies map of a dolomitic green algal bioherm and associated carbonate sands cross-sectioned at the Hainsfarth quarry at the Büschelberg (Arp 1995b). Note that black lines indicate laminated sinter veneers, i.e., short-term discontinuities in bioherm growth. 

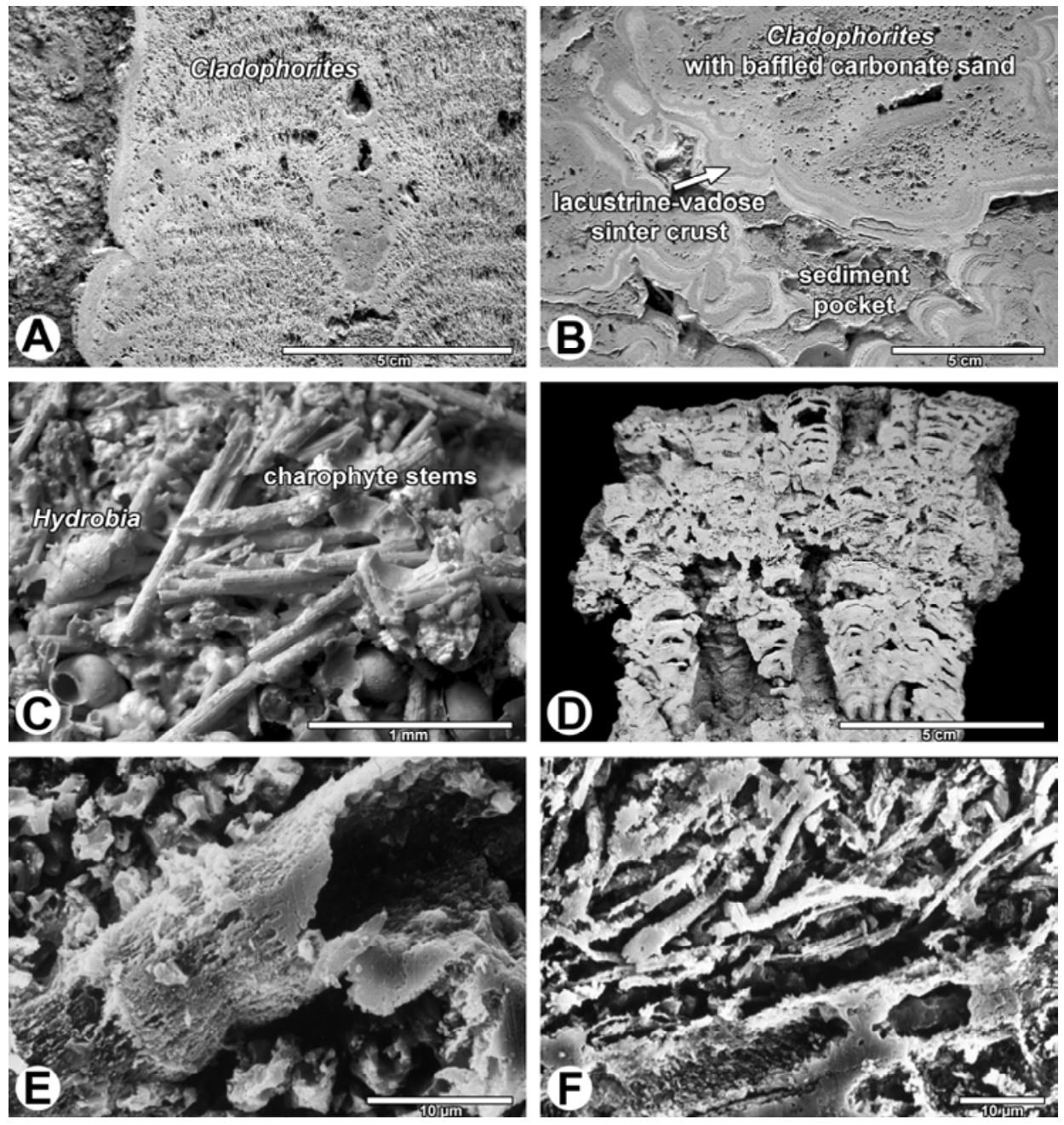

Plate 4. Algal bioherm carbonates of the Miocene Ries crater lake. (A) Cladophorites-framestone, Ehingen; (B) Cladophorites-bafflestone, NW of Maihingen; (C) Accumulation of charophyte stem fragments associated with the mesogastropod Hydrobia trochulus and the ostracod Strandesia risgoviensis. NNW of Maihingen; (D) Cyanobacterial stromatolite showing stacked hemispheroids. From the top of the algal bioherm section at Hainsfarth. From Arp (1995b); (E) SEM micrograph of an EDTA-etched stromatolite cutting plane showing the dolomitized sheath of an Oscillatoria-type cyanobacterial filament of $10 \mu \mathrm{m}$ diameter. Hainsfarth. From Arp (1995b); (F) SEM micrograph of an EDTA-etched stromatolite cutting plane showing $2-\mu \mathrm{m}$-thin, undulating filaments of cyanobacterial or bacterial origin, which are associated with the Oscillatoria-type cyanobacterial filaments. Hainsfarth. From Arp (1995b). 
Cyanobacterial microfossils are much more rare and restricted to few lithostratigraphic horizons exhibiting skeletal stromatolites (Pl. 4D). Erect filament traces and microcrystalline tubes of $8-12 \mu \mathrm{m}$ internal diameter may result from former Oscillatoria-type cyanobacteria (Pl. 4E), whereas 1.5 - to $2-\mu \mathrm{m}$-thin, undulating filaments associated with them may be either cyanobacteria or Chloroflexus-type bacteria (Pl. 4F; Arp 1995b). Brushlike arranged filament traces of 10-15 $\mu \mathrm{m}$ diameter without defined tube wall might result from Phormidium-type cyanobacteria. Coccoid microfossils of possible cyanobacteria, 10-15 $\mu \mathrm{m}$ diameter, have only been detected in one blackened stromatolite clast, redeposited in the palustrine limestones (Peters 2003). By contrast, hollow spheres of 120-130 $\mu \mathrm{m}$ diameter, locally enriched in depressions between stromatolite domes, are arthropod eggs (Arp 1995b), not coccoid green algae („Chlorellopsis").

Hainsfarth-type bioherms show a clear cyclic facies development reflecting climatically-driven lake-level fluctuations: Palustrine limestones with Cepaea sylvestrina are the first deposits of a cycle, commonly preserved in pockets of the preceding bioherm cycle. Bioherm growth starts with nodular Cladophorites-bafflestones, followed by cones of rhythmically grown Cladophorites-framestones, and further nodular Cladophorites-bafflestones. Cycle tops are characterized by skeletal stromatolites, subsequent erosion and pocket formation (Fig. 11).

\section{Stop 6: Wallerstein castle rock, Ries crater}

Location: Topographic Map of Bavaria $1: 25000$ Sheet 7128 Nördlingen, east 3608 450, north 5417 430. Castle rock in the centre of the village Wallerstein, $\mathrm{N}$ of Nördlingen.

Geological Formation: Spring mound carbonates of the Ries crater lake sediments.

Geological Age: Miocene, ca. 14 Ma.

Description: Spring mound carbonates, also known as "travertines" in the Ries basin, form localized mounds and pinnacles with steep sides of meter to several decametre in size (Wolff \& Füchtbauer 1976, Bolten 1977, Pache et al. 2001). Large mounds, such as the Wallerstein castle rock, are commonly located on basement blocks of the crystalline ring structure (Figs. 9, 12). They are up to $30 \mathrm{~m}$ high and exhumed from their surrounding lake clays by Pleistocene erosion (Bolten 1977).

The "travertines" consist of porous calcitic limestones with only traces of aragonite. In contrasts to the algal bioherms, dolomite is almost absent. Central parts of the mounds and pinnacles (Pl. 5A) are composed of so-called sickle-cell limestones (Pl. 5B; „Sichelzellenkalke“; Reis 1926). These are highly porous limestones con- 
sisting of 100-200 $\mu \mathrm{m}$ thick microcrystalline calcite sheets spanning over $\mathrm{mm}$ - to $\mathrm{cm}$-sized lenticular to sickle-shaped voids. Bubble-like structures (Pl. 5C) and networks of micrite threads occur as well (Pache et al. 2001). Laminated and dendroid sinter cements (Pl. 5D) and curtains of thin stalactites, which veneer dissolution voids and fissures, too, stabilize this initial framework. At the northside base of the castle rock, sickle-cell limestones form the cores of steep-sided pinnacles up to $4.5 \mathrm{~m}$ height, which are veneered by dm-thick thrombolitic crusts of clotted fabric. On top of these pinnacles, a bed of more or less horizontal, platy non-skeletal stromatolites is developed, indicating lake-level lowstand conditions. Saline conditions are indicated by pseudomorphs of unidentified monoclinic- prismatic evaporite minerals. Non-skeletal stromatolites as well as thrombolites are rich in faecal pellets resembling that of the modern brine shrimp Artemia (Pl. 5E).

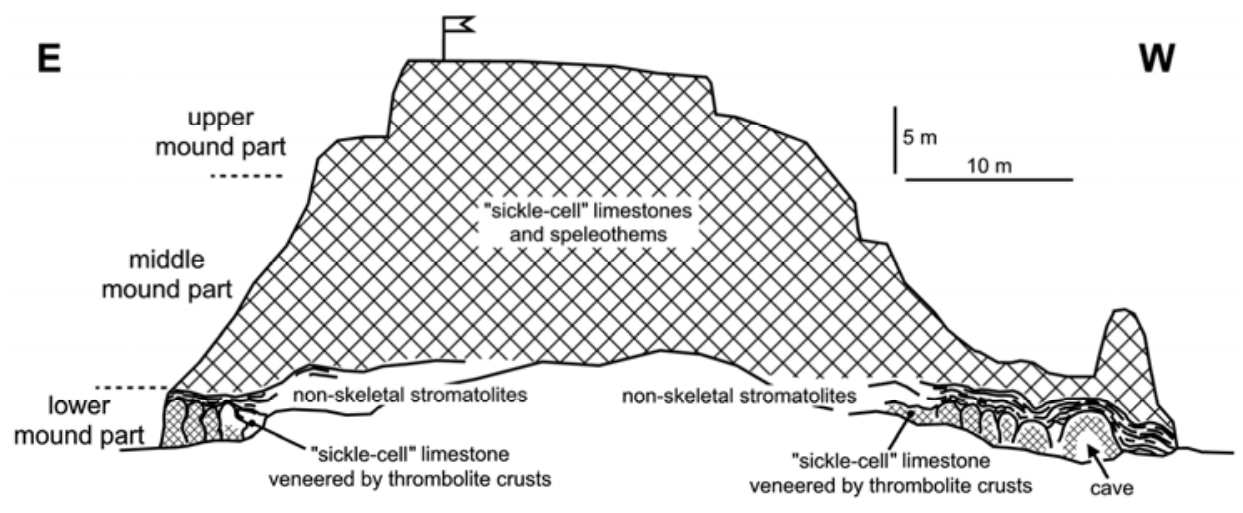

Fig. 12. Schematic section of the "travertine" mound Wallerstein showing the different facies units. From Pache et al. (2001).

\section{lake level highstand: shallow subaquatic growth}

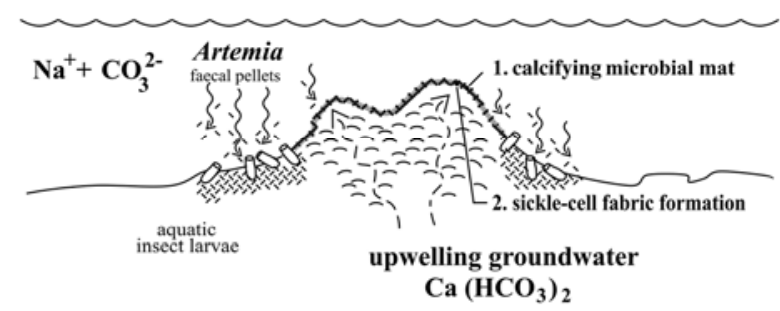

lake level lowstand: subaerial exposure

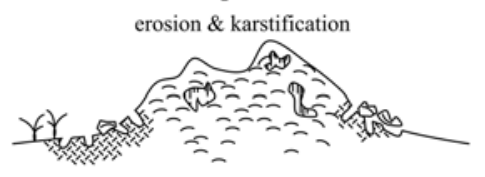

Fig. 13. Model of spring mound formation in the Ries soda lake. Periods of subaquatic growth and prolonged exposure alternated. After initial impregnation of microbial mats within the mixing zone, sickle-cell fabrics form by bacterial degradation and shrinkage of the mats (Arp 1995b, Arp et al. 1998). 

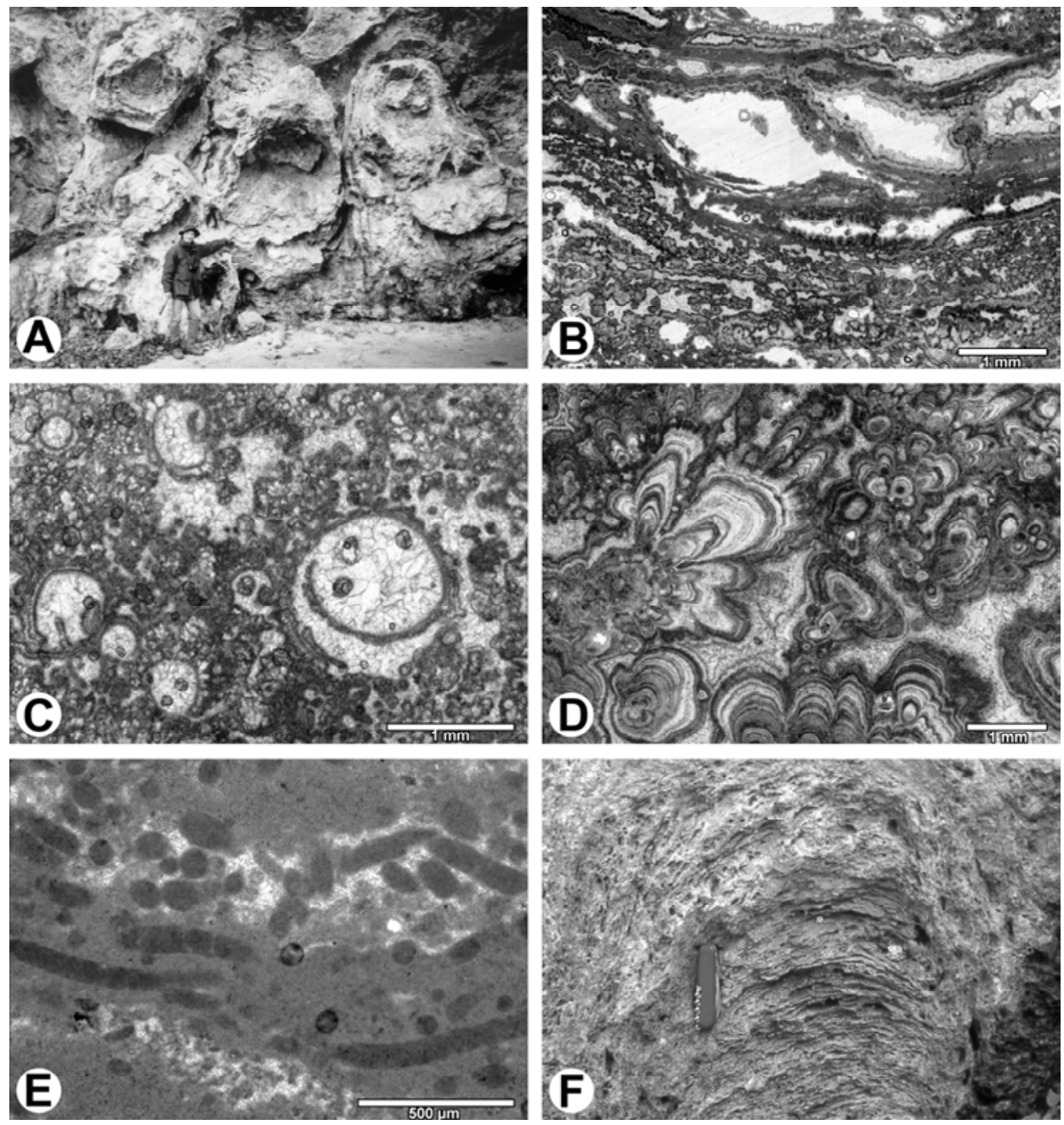

Plate 5. Spring mound carbonates of the Wallerstein castle rock, Miocene Ries crater lake. From Pache et al. (2001). (A) Field view of the northern, basal part of the Wallerstein castle rock showing barrel-shaped sickle-cell limestone cones veneered by thrombolite crusts. The core parts of these structures have largely been removed by quarrying; (B) "Sickle-cell" limestone showing microcrystalline sheets with inclusion-rich, fibrous cements spanning over lenticular voids. Southern slope of the Wallerstein; (C) Bubble-rich variety of "sickle-cell" limestone. The gas bubbles, which are preserved by micritic films, are partly collapsed and enclosed by spherulitic to dendroid sinter. Southern slope of the Wallerstein; (D) Dendroid sinter framestone with radiating, more or less upward directed finger-like elements. Middle part of the Wallerstein (ca. $15 \mathrm{~m}$ below top); (E) Detail of a non-skeletal stromatolite showing elongated faecal pellets which probably were produced by the brine shrimp Artemia. Above basal "travertine" bodies at the N-side of the Wallerstein; (F) Stromatolitic column of sickle-cell limestone at the stairway to the Wallerstein summit. 
Locally sickle-cell limestones form $\mathrm{m}$-sized columns of stromatolitic appearance, e. g., at the stairway to the summit (Pl. 5F). At the eastern side below the summit, curtains of thin stalactites occur, reflecting early subaerial exposure already in Miocene times. On top of the castle rock, concentric structures of pinnacle crosscuttings are visible.
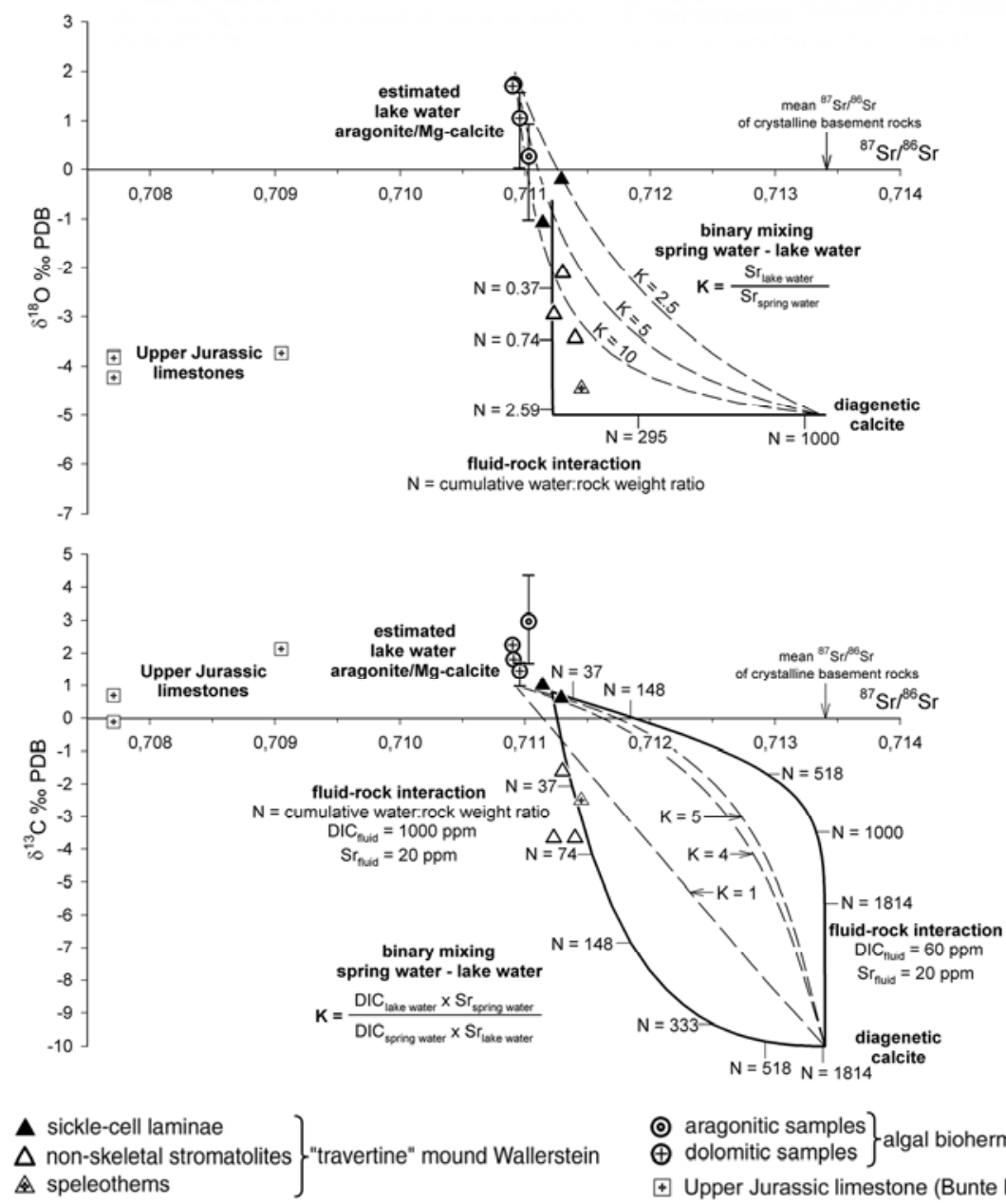

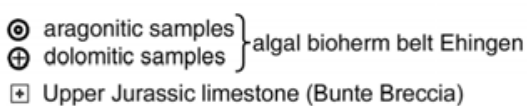

Fig. 14. Covariation plots of $\delta^{18} \mathrm{O}$ vs. ${ }^{87} \mathrm{Sr} /{ }^{86} \mathrm{Sr}$ and $\delta^{13} \mathrm{C}$ vs. ${ }^{87} \mathrm{Sr} /{ }^{86} \mathrm{Sr}$ of spring mound carbonates in comparison to algal bioherms and Upper Jurassic limestones are shown. Model curves demonstrate binary mixing of lake water and spring water from crystalline basement rocks (dashed lines) and fluid-rock interaction within the upwelling groundwater flow (solid lines). Note that ${ }^{87} \mathrm{Sr} /{ }^{86} \mathrm{Sr}$ isotope ratios of Wallerstein carbonates are shifted towards that of crystalline basement rocks, if compared to ${ }^{87} \mathrm{Sr} /{ }^{86} \mathrm{Sr}$ isotope ratios of algal bioherms. On the other hand, stable oxygen and carbon isotope analyses indicate that the $\mathrm{CO}_{3}{ }^{2-}$ of the primary spring mound carbonates is largely derived from the lake water. From Pache et al. (2001). 
The formation of the Ries lake spring mounds is interpreted to be similar to that of present-day soda lake spring mounds like that of the Mono Lake (Scholl \& Taft 1964), Lake Van (Kempe et al. 1991) and Lake Nuoertu (Arp et al. 1998). These pinnacles form at sublacustrine springs by mixing of $\mathrm{Ca}^{2+}$-supplying groundwater with bicarbonate-rich alkaline lake water (Fig. 13), a model supported by ${ }^{87} \mathrm{Sr} /{ }^{86} \mathrm{Sr}$, $\delta^{13} \mathrm{C}$ and $\delta^{18} \mathrm{O}$ data for the Wallerstein castle rock (Fig. 14). Cyanobacterial biofilms flourishing at the sublacustrine spring sites became loosely $\mathrm{CaCO}_{3}$ impregnated due to the extremely high supersaturation of mixing zone waters. Compared to the mixing process, photosynthetic activity is of minor importance in causing $\mathrm{CaCO}_{3}$ precipitation. However, the characteristic sickle-cell fabric results from exopolymer degradation by heterotrophic bacteria, mucus shrinkage and secondary $\mathrm{Ca}^{2+}$ release from the exopolymers (Arp et al. 1998). This process only promotes calcification to form lithified microbialites if the dissolved inorganic carbon of the lake water buffers the simultaneously released $\mathrm{CO}_{2}$ (Arp et al. 2003). Consequently, sickle-cell fabrics are considered to be indicative of soda lakes. To date, no evidence has been found that sublacustrine spring waters of the Ries lake basin have been thermal, contrasting with the assumptions of early investigators (Gümbel 1870, Klähn 1926, Seemann 1935). Consequently, the spring mound carbonates are no real travertines, but cool-water tufa deposits.

Well-preserved vertebrate remains, such as avian skulls, feather imprints, eggshells and diverse mammals, have been reported from the Ries spring mounds (Deffner \& Fraas 1877, Bolten 1977, Heizmann \& Fahlbusch 1983, Kohring \& Sachs 1997). However, sickle-cell limestones, thrombolites and stromatolites are disappointingly poor in fossils. A closer look to the fossil locations and associated freshwater gastropods suggests that these vertebrate remains are restricted to fissure fillings of a freshwater phase younger than the true spring mound carbonates.

\section{Stop 7: Tufa oncoids of the river Moosach, Molasse Basin}

Location: Topographic Map of Bavaria $1: 25000$ Sheet 7537 Moosburg an der Isar, east 4489 380, north 5364 500, $6 \mathrm{~km}$ northeast of the Airport Munich near Freising, $1.7 \mathrm{~km}$ ENE of the village Hangenham in the Isar valley, where an overhead power line crosses the river.

Geological Formation: Present-day tufa deposits.

Geological Age: Recent.

Description: The river Moosach is a small river left sided of the river Isar (Pl. 6A). Its stream bed has been artifically modified significantly since the $17^{\text {th }}$ century, and is now located on the floodplain of the Isar. Today, two small drainage channels near Inhausermoos north of Munich are considered as the source of the Moosach. Similar to other rivers crossing the Northern Alpine Molasse Basin, the river 
Moosach locally shows accumulations of tufa oncoids, here occasionally exceeding $15 \mathrm{~cm}$ in diameter.
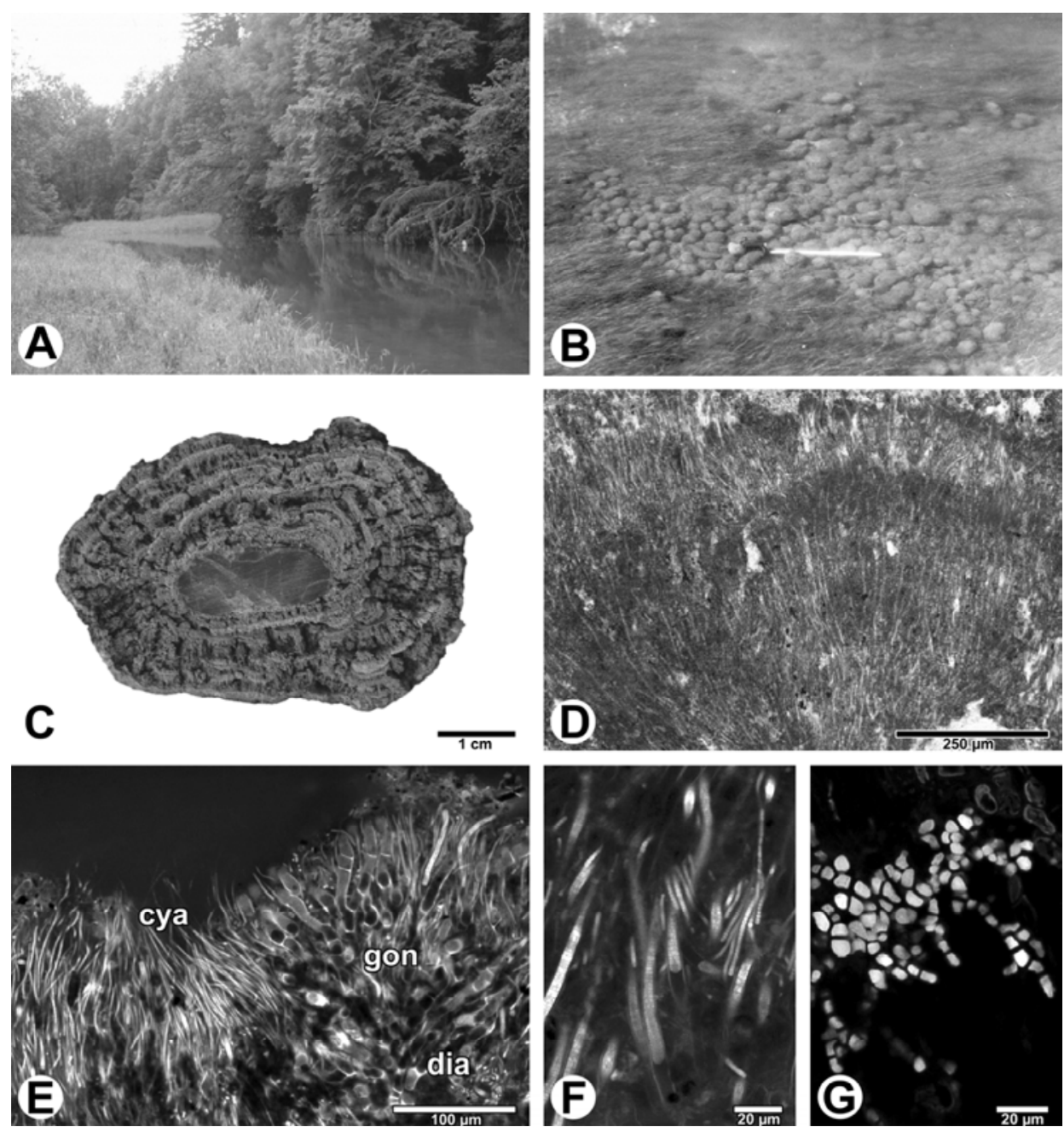

Plate 6. Present-day tufa onkoids of the river Moosach, Molasse Basin. (A) River Moosach at station M 3; (B) Field view of oncoid accumulation. Measuring tape is $30 \mathrm{~cm}$ long. Foto courtesy of Derek Peršoh; (C) Section of an oncoid, with a limestone pebble as nucleus and alternating porous and dense layers; (D) Thin section of tufa oncoid laminae showing radiating cyanobacterial filament traces; (E) Laserscanning micrograph (ex $488 \mathrm{~nm}, 633 \mathrm{~nm}$, em 565-615 nm, 639-704 nm) of the uppermost biofilm surface with filamentous cyanobacteria (cya), green algae of the genus Gongrosira (gon) and patches of diatoms (dia); (F) Erect filaments of Lyngbya- and Homoeothrix-morphotype cyanobacterial filaments. Laserscanning micrograph (ex $488 \mathrm{~nm}, 633 \mathrm{~nm}$, em 565-615 nm, 639-704 nm); (G) Endolithic cyanobacterium Hyella within deeper, calcified oncoid biofilms parts. Laserscanning micrograph (ex $488 \mathrm{~nm}, 633 \mathrm{~nm}$, em 565-615 nm, 639-704 nm). 
Although the Molasse Basin it is not a karst region, many rivers in this region show a $\mathrm{Ca}-\mathrm{HCO}_{3}$-dominated hydrochemical composition thereby favouring tufa formation. This is largely because groundwaters discharge from calcareous MiocenePliocene gravels (Upper Freshwater Molasse) as well as till and marls from last glaciations, which both contain limestone pebbles derived from the Northern Limestone Alps.

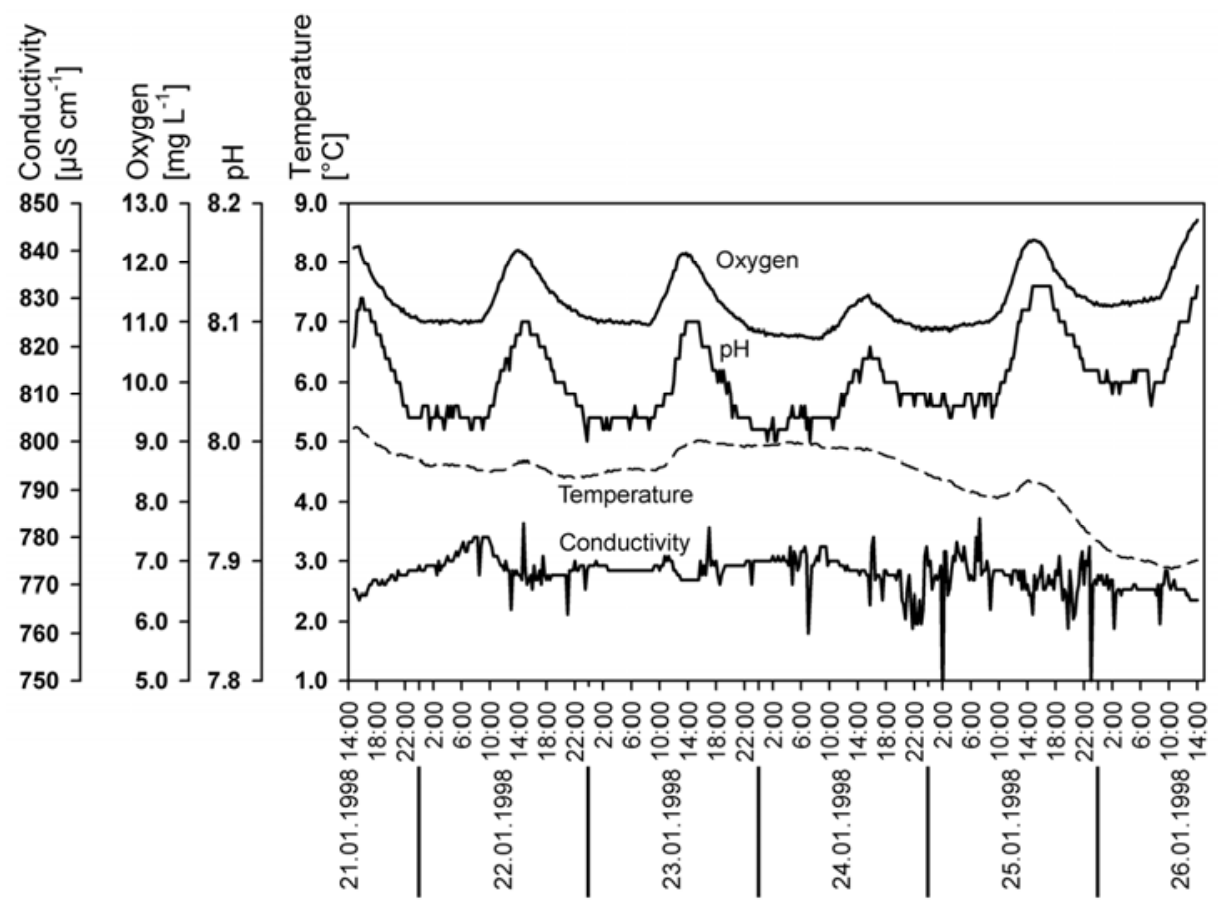

Fig. 15. Conductivity, oxygen concentrations, $\mathrm{pH}$ and temperature of the river Moosach at station M 3 in January 1998. Data courtesy of Derek Peršoh.

In the river Moosach tufa oncoids are common between the villages Hangenham and Asenkofen (Pl. 6B). Comparable oncoids have been reported and described in detail from other rivers and lakes of the Molasse Basin (Schäfer \& Stapf 1978, Rott 1991, Hägele et al. 2006). Locally, tufa stromatolites cover the stream bottom, which is considered by some ecologists to have a negative impact on the distribution of the highly endangered noble crayfish (Astacus astacus) which still occurs in this region (Schütze in Peršoh 1998).

There are no extensive hydrochemical data published on the river Moosach. Data from a station downstream near the confluence with the river Isar are provided in Table 1. and show a calcite supersaturation already dropped below sufficient values 
for biofilm calcification. However, Peršoh (1998) reports that during the course of the river Moosach, a decrease in $\mathrm{pCO}_{2}$ combined with an increase of calcite saturation from 0.4 to 1.2 is observed. In addition, $\mathrm{pH}, \mathrm{O}_{2}$ concentrations, conductivity and temperature have been monitored in January 1998 at the field trip site demonstrating diurnal, synchronous cycles of $\mathrm{O}_{2}$ and $\mathrm{pH}$ (8.05 to 8.18), with maxima in the afternoon (Fig. 15). At the same time, conductivity remains without significant changes, and non-cyclic temperature changes between 3 and $5^{\circ} \mathrm{C}$ were observed.

Table 1. Hydrochemistry of the river Moosach, station 17, $5^{\text {th }}$ of August 1996. Data courtesy of Derek Peršoh.

$\begin{array}{ll}\mathrm{pH} & 7.80 \\ \mathrm{~T} & 13.1{ }^{\circ} \mathrm{C} \\ \mathrm{Ca}^{2+} & 2.89 \mathrm{mmol} \mathrm{L}^{-1} \\ \mathrm{Mg}^{2+} & 0.98 \mathrm{mmol} \mathrm{L}^{-1} \\ \mathrm{Na}^{+} & 0.91 \mathrm{mmol} \mathrm{L}^{-1} \\ \mathrm{~K}^{+} & 0.11 \mathrm{mmol} \mathrm{L}^{-1} \\ \mathrm{Cl}^{-} & 0.93 \mathrm{mmol} \mathrm{L}^{-1} \\ \mathrm{SO}_{4}^{2-} & 0.33 \mathrm{mmol} \mathrm{L}^{-1} \\ \text { Total Alkalinity } & 3.63 \mathrm{meq} \mathrm{L}^{-1} \\ \mathrm{SI}_{\mathrm{Cc}} & 0.53 \\ \mathrm{pCO}_{2} & 2820 \mu \mathrm{atm}\end{array}$

Oncoids of the river Moosach are 2 to $15 \mathrm{~cm}$ in size, with dark-green surface biofilms (Pl. 6C). Porous layers composed of microspar crystals are 1 to $2 \mathrm{~mm}$ thick, whereas dense microcrystalline layers are 0.5 to $1.5 \mathrm{~mm}$, both with erect, radiating filament traces of $10 \mu \mathrm{m}$ diameter (Pl. 6D). ${ }^{137} \mathrm{Cs}$ concentrations continuously declining from core to outer layers of an oncoid with $6 \mathrm{~cm}$ thick cortex point to a oncoid formation that postdates the Chernobyl nuclear disaster in 1986 (Peršoh 1998).

Biofilms are largely composed of filamentous cyanobacteria and abundant green algae (Pl. 6E). Six morphotypes of filamentous and coccoid cyanobacteria have been detected by Peršoh (1998), among them Lyngbya, Phormidium, Homoeothrix and the endolithic genus Hyella (Pl. 6F-G). Rott (1994) described 20 cyanobacterial species based on traditional botanical classification, one red alga, and 38 diatom species from similar oncoids of the river Alz. The lack of the cyanobacterial genus Rivularia and other heterocystous taxa in the river Moosach oncoids may reflect influx of nitrate from adjacent agricultural areas. Apart from that, numerous nonphototrophic bacteria, among them Actinobacteria, are present.

The fomation of tufa oncoids appears to be largely controlled by diurnal photosynthesis-induced calcite precipitation (largely due to cyanobacterial activity), 
similar to tufa stromatolites as described in stop 2 Erasbach. With regard to their spherical morphology and concentric growth pattern, movement and rotation of the tufa oncoids does not seem to be a crucial prerequisite (Hägele et al. 2006). Nonetheless, occasional flooding events shift and rotate the oncoids in the river Moosach, and cause temporary decline in calcite supersaturation.

\section{Acknowledgements}

Andreas Reimer, University of Göttingen, and Derek Peršoh, LMU München provided water chemistry data of the Steinerne Rimne Erasbach and river Moosach, respectively. Martin Görlich, Altdorf, is kindly acknowledged for the permission to access the Sengenthal quarry. I am grateful to Martin Röper for guidance in Solnhofen, Bürgermeister-MüllerMuseum and quarry.

\section{References}

Arp, G. 1995a. Ein Diplopode (Tausendfüßler i.e.S.) aus den lakustrinen Karbonaten des Nördlinger Rieses (Miozän, Süddeutschland): Morphologie und Integumentstruktur. Paläontologische Zeitschrift 69: 135-147.

Arp, G. 1995b. Lacustrine bioherms, spring mounds, and marginal carbonates of the Ries-impactcrater Miocene, Southern Germany. Facies 33: 35-90.

Arp, G. 2001. Fazies, Stratigraphie und Ammonitenfauna des Mittleren und Oberen Dogger bei Neumarkt i. d. Opf. (Bajocium-Oxfordium, Süddeutschland). Berliner Geowissenschaftliche Abhandlungen (E: Paläobiologie) 36: 189-241.

Arp, G.; Hofmann, J. \& Reitner, J. 1998. Microbial fabric formation in spring mounds („microbialites") of alkaline salt lakes in the Badain Jaran Sand Sea, PR China. Palaios 13: 581-592.

Arp, G.; Wedemeyer, N. \& Reitner, J. 2001. Fluvial tufa formation in a hard-water creek (Deinschwanger Bach, Franconian Alb, Germany). Facies 44: 1-22.

Arp, G.; Reimer, A. \& Reitner, J. 2003. Microbialite formation in seawater of increased alkalinity, Satonda Crater Lake, Indonesia. Journal of Sedimentary Research 73: 105-127.

Baier, A. 2002. Die "Steinerne Rinne" am Berg südlich Erasbach/Opf. - eine Untersuchung zur Hydrologie und -chemie des Seichten Karstes. Geologische Blätter für Nordost-Bayern 52: 139-194.

Bernier, P.; Gaillard, C.; Gall, J. C.; Barale, G.; Bourseau, J. P.; Buffet, E. \& Wenz, S. 1991. Morphogenetic impact of microbial mats on surface structures of Kimmeridgian micritic limestones (Cerin, France). Sedimentology 38: 127-136.

Bissett, A.; Beer, D. de; Schoon, R.; Shiraishi, F.; Reimer, A. \& Arp, G. 2008, in press. Microbial mediation of stromatolite formation in karst-water creeks. Limnology \& Oceanography.

Bloos, G.; Dietl, G. \& Schweigert, G. 2005. Der Jura Süddeutschlands in der Stratigraphischen Tabelle von Deutschland 2002. Newsletter on Stratigrapby 41: 263-277.

Bolten, R. H. 1977. Die karbonatischen Ablagerungen des obermiozänen Kratersees im Nördlinger Ries. Dissertation Universität München: $228+21$ pp., 6 pls., München.

Buisonje, P. H. de 1972. Recurrent red tides, a possible origin of the Solnhofen limestone, I+II. Koninklijke Nederlandse Akademie van Wetenschappen (B) 75 (2): 152-177.

Callomon, J. H.; Dietl, G.; Galácz, A.; Gradl, H.; Niederhöfer, H.-J. \& Zeiss, A. 1987. Zur Stratigraphie des Mittel- und unteren Oberjuras in Sengenthal bei Neumarkt/Opf. (Fränkische Alb). Stuttgarter Beiträge zur Naturkunde (B) 132: 1-53. 
Chao, E. T. C. \& Littler, J. 1963. Additional evidence for the impact origin of the Ries basin, Bavaria, Germany. Geological Society of America, Special Paper 73: p. 127.

Chao, E. T. C. 1977. The Ries crater of southern Germany, a model for large basins on planetary surfaces. Geologisches Jabrbuch (A) 43: 3-81.

Cousin S.; Brambilla E. \& Stackebrandt E. 2007. Assessing the microbial diversity in a hard water rivulet and deposited tufa. Proceedings of the 11th International Conference on Cultures Collections: 92-95, Goslar.

Dahanayake, K.; Gerdes, G. \& Krumbein, W. E. 1985. Stromatolites, oncolites and oolites biogenically formed in situ. Naturwissenschaften 72: 513-518.

Davies, P. J.; Bubela, B. \& Ferguson, J. 1978. The formation of ooids. Sedimentology 25: 703-729.

Deffner, C. \& Fraas, O. 1877. Begleitworte zur geognostischen Spezialkarte von Württemberg. Atlasblätter Bopfingen und Ellenberg. - 36 pp., Stuttgart.

Dietl, G. \& Etzold A. 1977. The Aalenian at the Type Locality. Stuttgarter Beiträge zur Naturkunde (B) 30: 1-13.

Dietl, G. 1977. The Braunjura (Brown Jurassic) in Southwest Germany. Stuttgarter Beiträge zur Naturkunde (B) 25: 1-41.

Dohmann, C. 1991. Mikrofaziell-palökologische Analyse eines Algen-Schwamm-Bioherms aus dem mittleren Oxford von Sengenthal. Mitteilungen der Bayerischen Staatssammlung für Paläontologie und bistorische Geologie 31: 3-25.

Ernstson, K. \& Pohl, J. 1977. Neue Modelle zur Verteilung der Dichte und Geschwindigkeit im RiesKrater. Geologica Bavarica 75: 355-371.

Flügel E. \& Steiger, T. 1981. An Upper Jurassic sponge-algal buildup from the northern Frankenalb, West Germany. In: Toomey, D. F. (ed.): European fossil reef models. SEPM Special Publication 30: 371-397.

Flügel, E. 1977. Verkalkungsmuster porostromater Algen aus dem Malm der Südlichen Frankenalb. Geologische Blätter für Nordost-Bayern 27: 131-140.

Ford, T. D. 1989. Tufa - the whole dam story. Cave Science 16: 39-49.

Franke, W. 1999. Tectonic and plate tectonic units at the North Gondwana Margin: Evidence from the Central European Variscides. Abhandlungen der Geologischen Bundesanstalt 54: 7-13.

Fritz, G. K. 1958. Schwammstotzen, Tuberolithe und Schuttbreccien im Weißen Jura der Schwäbischen Alb. Eine vergleichende petrogenetische Untersuchung. Arbeiten aus dem geologischpaläontologischen Institut der Technischen Hochschule Stuttgart (Neue Folge) 13: 1-119.

Fürsich, T. F.; Werner, W.; Schneider, S. \& Mäuser, M. 2007. Sedimentology, taphonomy, and palaeoecology of a laminated plattenkalk from the Kimmeridgian of the northern Franconian Alb (southern Germany). Palaeogeography Palaeoclimatology Palaeoecology 243: 92-117.

Gaillard, C. ; Bernier, P. \& Gruet, Y. 1994. Le lagon d'Aldabra (Seychelles, Océan Indien), un modèle pour le paléoenvironnement de Cerin (Kimméridgien supérieur, Jura méridinal, France). Geobios, Special Issue 16: 331-348.

Gerdes, G. \& Krumbein, W. E. 1987. Biolaminated deposits. Lecture Notes in Earth Sciences 9: 1-183.

German Stratigraphic Commission (ed.) 2002. Stratigraphische Tabelle von Deutschland 2002. - 1 poster, Potsdam (GeoForschungsZentrum).

Glassl, R. \& Schieber, M. 1990. Die Tuffrinne von Erasbach. Archaeopteryx 8: 127-139.

Grüninger, W. 1965. Rezente Kalktuffbildung im Bereich der Uracher Wasserfälle. Abhandlungen zur Karst- und Höblenkunde (E: Botanik) [1965] (2): 1-113.

Gümbel, C. W. von 1870. Über den Riesvulkan und über vulkanische Erscheinungen im Rieskessel. Sitzungsberichte der königlich-bayerischen Akademie der Wissenschaften, mathematisch-physikalische Classe I [1870] (2): 153-200. 
Gümbel, C. W. von 1891. Geognostische Beschreibung des Königreiches Bayern. IV. Geognostische Beschreibung der Fränkischen Alb (Frankenjura). - 763 pp., Kassel.

Hägele, D.; Leinfelder, R.; Grau, J.; Burmeister, E. G. \& Struck, U. 2006. Oncoids from the river Alz (southern Germany): Tiny ecosystems in a phosphorus-limited environment. Palaeogeography Palaeoclimatology Palaeoecology 237: 378-395.

Heikoop, J. M.; Tsujita, C. J.; Risk, M. J.; Tomascik, T. \& Mah, A. J. 1996. Modern iron ooids from a shallow-marine volcanic setting: Mahengetang, Indonesia. Geology 24: 759-762.

Heizmann, E. P.J. \& Fahlbusch, V. 1983. Die mittelmiozäne Wirbeltierfauna vom Steinberg (Nördlinger Ries). Eine Übersicht. Mitteilungen der Bayerischen Staatssammlung für Paläontologie und historische Geologie 23: 83-93.

Hiller, K. 1964. Über die Bank- und Schwammfazies des Weißen Jura der Schwäbischen Alb (Württemberg). Arbeiten aus dem geologisch-paläontologischen Institut der Technischen Hochschule Stuttgart (Neue Folge) 40: 1-190.

Hölder, H. 1994. E. F. Hiemers Traktat über das „Medusenhaupt“ Schwabens (Seirocrinus subangularis) aus dem Jahr 1724. Suttgarter Beiträge zur Naturkunde (B) 213: 1-29.

Hough, R. M.; Gilmour, I.; Pillinger, C. T.; Arden, J. W.; Gilkes, K. W. R.; Yuan, Y. \& Milledge, H. J. 1995. Diamond and silicon carbide in impact melt rock from the Ries impact crater. Nature 378: 41-44.

Hückel, U. 1974. Geochemischer Vergleich der Plattenkalke Solnhofens und des Libanon mit anderen Kalken. Neues Jahrbuch für Geologie und Paläontologie Abhandlungen 145: 279-305.

Hüttner, R. 1969. Bunte Trümmermassen und Suevit. Geologica Bavarica 61: 142-200.

Hüttner, R. 1977. Impaktgesteine des Rieses. Geologica Bavarica 76: 108-175.

Hüttner, R. \& Schmidt-Kaler, H. 1999. Die Geologische Karte des Rieses 1 : 50000 [2. überarbeitete Auflage]. Erläuterungen zu Erdgeschichte, Bau und Entstehung des Kraters sowie zu den Impaktgesteinen. Geologica Bavarica 104: 7-76.

Irion, G. \& Müller, G. 1968. Mineralogy, petrology and chemical composition of some calcareous tufa from the Schwäbische Alb, Germany. In: Müller, G. \& Friedman, G. M. (eds.): Recent Developments in Carbonate Sedimentology in Central Europe: 157-171, Berlin (Springer).

Kalkowsky, E. 1908. Oolith und Stromatolith im norddeutschen Buntsandstein. Zeitschrift der Deutschen geologischen Gesellschaft 60: 68-125.

Kempe, S.; Kazmierczak, J.; Landmann, G.; Konuk, T.; Reimer, A. \& Lipp, A. 1991. Largest known microbialites discovered in Lake Van, Turkey. Nature 349: 605-608.

Keupp, H. 1977. Ultrafazies und Genese der Solnhofener Plattenkalke (Oberer Malm, Südliche Frankenalb). Abhandlungen der Naturbistorischen Gesellschaft Nürnberg 37: 1-128.

Keupp, H.; Jenisch, A.; Herrmann, R.; Neuweiler, F. \& Reitner, J. 1993. Microbial carbonate crusts a key to the environmental analysis of fossil spongiolites? Facies 29: 41-54.

Keupp, H.; Brugger, H.; Galling, U.; Hefter, J.; Herrmann, R.; Jenisch, A.; Kempe, S.; Michaelis, W.; Seifert, R. \& Thiel, V. 1996. Paleobiological controls of Jurassic spongiolites. Göttinger Arbeiten zur Geologie und Paläontologie, Sonderband 2: 209-214.

Kimberley, M. M. 1994. Debate about ironstone: has solute supply been surficial weathering, hydrothermal convection, or exhalation of deep fluids? Terra Nova 6: 116-132.

Klähn, H. 1926. Vergleichende paläolimnologische, sedimentpetrographische und tektonische Untersuchungen an miocänen Seen der Schwäbischen Alb. Neues Jabrbuch für Mineralogie, Geologie und Paläontologie (Abteilung B) 55: 274-428.

Knorr, G. W. \& Walch, J. E. J. 1755-1771. Die Naturgeschichte der Versteinerungen zur Erläuterung der Knorrischen Sammlung von Merkwürdigkeiten der Natur. - Part I (1755): 689 pp., Part II (1768), Part III (1771). - Nürnberg (Felssecker). 
Kohring, R. \& Sachs, O. 1997. Erhaltungsbedingungen und Diagenese fossiler Vogeleischalen aus dem Nördlinger Ries (Miozän, MN6). Archaeopteryx 15: 73-96.

Krumbeck, L. 1928. Faltung, untermeerische Gleitfaltung und Gleitstauchung im Tithon der Altmühlalb. Neues Jahrbuch für Mineralogie, Geologie und Paläontologie (B, Beilageband) 60: 133-166.

Leinfelder, R. R.; Nose, M.; Schmid, D. U. \& Werner, W. 1993. Microbial crusts of the Late Jurassic; composition, palaeo-ecological significance and importance in reef construction. Facies 29: 195230.

Leinfelder, R. R.; Werner, W.; Nose, M.; Schmid, D. U.; Krautter, M.; Laternser, R.; Takacs, M. \& Hartmann, D. 1996. Paleoecology, growth parameters and dynamics of coral, sponge and microbolite reefs from the Late Jurassic. Göttinger Arbeiten zur Geologie und Paläontologie, Sonderband 2: 227-248.

Mayer-Eymar, C. 1864. Tableau synchronistique des terrains jurassiques. - 1 Table, Zurich.

Meyer, C.; Reimold, U.; Wünnemann, K. \& Jébrak, M. 2007. The question of the evolution of the ejecta plume and the origin of suevite of the Ries Crater, Germany. In: Bridging the gap II: Effect of target properties on the impact cratering process, Montreal, Canada (abstract).

Meyer, R. \& Schmidt-Kaler, H. 1983. Erdgeschichte sichtbar gemacht. Ein geologischer Führer durch die Altmüblalb. - 260 pp., München (Bayerisches Geologisches Landesamt).

Meyer, R. 1981a. Malm. In: Bayerisches Geologisches Landesamt (ed.): Erläuterungen zur Geologischen Karte von Bayern 1: 500 000: 62-68, München.

Meyer, R. 1981b. Kreide. In: Bayerisches Geologisches Landesamt (ed.): Erläuterungen zur Geologischen Karte von Bayern 1: 500 000: 68-70, München.

Mohr, K.; Bruns, S.; Behnke, A.; Kipp,V.; Brambilla, E.; Päuker, O.; Cousin, S.; Steiner, U.; Shiraishi, F.; Reimer, A.; Arp, G.; Friedl, T. \& Stackebrandt, E. 2006. Microalgal and prokaryotic biodiversity in tufa-forming biofilms of Germany. International Sedimentological Congress 2006, Abstract Volume B: p. 262, Fukuoka.

Nitzopoulos, G. 1974. Faunistisch-ökologische, stratigraphische und sedimentologische Untersuchungen am Schwammstotzen-Komplex bei Spielberg am Hahnenkamm (Ob. Oxfordien, Südliche Frankenalb). Stuttgarter Beiträge zur Naturkunde (B) 16: 1-143.

Oppel, A. 1856-58. Die Juraformation Englands, Frankreichs und des südwestlichen Deutschlands, nach ihren einzelnen Gliedern eingetheilt und verglichen. Jahreshefte des Vereins für vaterländische Naturkunde in Württemberg 12 (1856): 121-556, 13 (1857): 141-396, 14 (1858): 129-291, 64 Tab., 1 map.

Pache, M.; Reitner, J. \& Arp, G. 2001. Geochemical evidence for the formation of a large Miocene „travertine“ mound at a sublacustrine spring in a soda lake (Wallerstein castle rock, Nördlinger Ries, Germany). Facies 45: 211-230.

Pentecost, A. 2005. Travertine. - 446 pp., Berlin (Springer).

Peršoh, D. 1998. Onkoide in Moosach und Sempt. Entstehung, Struktur und Verbreitung. Diplomarbeit Technische Universität München: 63 pp., München.

Peters, H. 2003. Faziesverteilung und Dolomitisierung der Karbonatsedimente des Rieskratersees im Gebiet Oettingen i. Bay. - Hainsfarth (Miozän, Süddeutschland). Diplomarbeit und -kartierung GeorgAugust-Universität Göttingen: 323 pp., 70 plates, 2 maps, Göttingen.

Quenstedt, F. A. 1858. Der Jura. - 842 pp. 100 pls., Tübingen (Laupp).

Reich, H. \& Horrix, W. 1955. Geophysikalische Untersuchungen im Ries und Vorries und deren geologische Bedeutung. Beiheft zum Geologischen Jabrbuch 19: 1-119.

Reich, M. in press. The 'Swabian Caput Medusae' (Jurassic Crinoidea, Germany). In: Echinoderms: Durham. Proceedings of the $12^{\text {th }}$ International Echinoderm Conference, Durham, NH 2006; Leiden A. A. Balkema Publishers). 
Reis, O. M. 1926. Zusammenfassung über die im Ries südlich von Nördlingen auftretenden Süßwasserkalke und ihre Entstehung. Jahresberichte und Mitteilungen des Oberrbeinischen Geologischen Vereins (Neue Folge) 14 [1925]: 176-190.

Riding, R. 1979. Origin and diagenesis of lacustrine algal bioherms at the margin of the Ries crater, Upper Miocene, southern Germany. Sedimentology 26: 645-680.

Riding, R. 1991. Classification of microbial carbonates. In: Riding, R. (ed.): Calcareous algae and stromatolites: 21-51, Berlin (Springer).

Röper, M. \& Rothgaenger, M. 1998. Die Plattenkalke von Solnhofen. Mörnsheim, Langenaltheim. - 94 S., Treuchtingen (Keller).

Röper, M.; Rothgaenger, M. \& Rothgaenger, K. 1996. Die Plattenkalke von Brunn (Landkreis Regensburg). - 102 pp., Eichendorf (Eichendorf Verlag).

Rott, E. 1991. Oncoids from the summer-warm River Alz (Bavaria). Morphology and dominant cyanophytes. Archiv für Hydrobiologie Supplementband 92 (= Algological Studies 64): 469-482.

Rott, E. 1994. Der Algenaufwuchs in der Oberen Alz (Oberbayern). Berichte des naturwissenschaftlichmedizinischen Vereins Innsbruck 81: 229-253.

Schäfer, A. \& Stapf, K. R. G. 1978. Permian Saar-Nahe Basin and recent Lake Constance (Germany). Two environments of lacustrine algal carbonates. In: Matter, A. \& Tucker, M. E. (eds.): Modern and Ancient Lake Sediments. International Association of Sedimentologists Special Publication 2: 83-107.

Schellmann, W. 1969. Die Bildungsbedingungen sedimentärer Chamosit- und Hämatit-Eisenerze am Beispiel der Lagerstätte Echte. Neues Jahrbuch für Mineralogie Abhandlungen 111: 1-31.

Scholl, D. W. \& Taft, W. H. 1964. Algae, contributors to the formation of calcareous tufa, Mono Lake, California. Journal of Sedimentary Petrology 34: 309-319.

Schwerdtschlager, J. J. 1919. Die lithographischen Plattenkalke des oberster Weißjura in Bayern. - 36 pp., München (Verlag Natur und Kultur).

Seemann, R. 1935. Massenhaftes Auftreten von Insektenpuppen im obermiozänen Süßwasserkalk vom Goldberg im Ries. Jahreshefte des Vereins für vaterländische Naturkunde in Württemberg 91: 19-21.

Shiraishi, F.; Bissett A.; Beer, D. de; Reimer, A. \& Arp, G. 2008a. Photosynthesis, respiration and exopolymer calcium-binding in biofilm calcification (Westerhöfer and Deinschwanger Creek, Germany). Geomicrobiology Journal 25: 83-94.

Shiraishi, F.; Bissett A.; Beer, D. de; Reimer, A. \& Arp, G. 2008b. Microbial effects on biofilm calcification, ambient water chemistry and stable isotope records (Westerhöfer Bach, Germany). Palaeogeography Palaeoclimatology Palaeoecology 262: 91-106.

Shoemaker, E. M. \& Chao, E. C. T. 1961. New evidence for the impact origin of the Ries basin, Bavaria, Germany. Journal of Geophysical Research 66: 3371-3378.

Stirn, A. 1964. Kalktuffvorkommen und Kalktufftypen der Schwäbischen Alb. Abhandlungen zur Karstund Höhlenkunde (E. Botanik) [1964] (1): 1-92.

Stöffler, D. 1977. Research drilling Nördlingen 1973: polymict breccias, crater basement, and cratering model of the Ries impact structure. Geologica Bavarica 75: 443-458.

Straaten, L. M. J. U. v. 1971. Origin of Solnhofen limestone. Geologie en Mijnbouw 50 (1): 3-8.

Sturesson, U.; Heikoop, J. M. \& Risk, M. J. 2000. Modern and Palaeozoic iron ooids - a similar volcanic origin. Sedimentary Geology 136: 137-146.

Urlichs, M. 1977. The Lower Jurassic in Southwestern Germany. Stuttgarter Beiträge zur Naturkunde (B) 24: $1-41$.

Usdowski, H. E. 1962. Die Entstehung der kalkoolithischen Fazies des norddeutschen Unteren Buntsandsteins. Beiträge zur Mineralogie und Petrographie 8 (3): 141-179.

Wagenplast, P. 1972. Ökologische Untersuchung der Fauna aus Bank- und Schwammfazies des Weißen Jura der Schwäbischen Alb. Arbeiten aus dem geologisch-paläontologischen Institut der Technischen Hochschule Stuttgart (Neue Folge) 67: 1-99. 
Walther, J. 1904. Die Fauna der Solnhofener Plattenkalke. Bionomisch betrachtet. Festschrift der Medirinisch-Naturwissenschaftlichen Gesellscbaft ₹u Jena 11: 135-214.

Wellnhofer, P. \& Röper, M. 2005. Das neunte Archaeopteryx-Exemplar von Solnhofen. Archaeopteryx 23: 3-21.

Wellnhofer, P. 2008. Archaeopteryx - Der Urvogel von Solnhofen. - 256 pp., München (Pfeil).

Werner, W.; Tischlinger, H. \& Schmidt-Kaler, H. 1992. Sulzkirchen und Sengenthal - zwei berühmte Fossilfundstellen am Rande der Frankenalb. Wanderungen in die Erdgeschichte 4: 112 pp., München (Pfeil).

Wirsing, G. \& Koch, R. 1986. Algen-Schwamm-Bioherme des Flachwasser-Bereiches (Schwäbische Alb, Weißjura Delta 3). Facies 14: 285-308, Erlangen.

Wolff, M. \& Füchtbauer, H. 1976. Die karbonatische Randfazies der tertiären Süßwasserseen des Nördlinger Ries und des Steinheimer Beckens. Geologisches Jabrbuch (D) 14: 3-53, Hannover.

Ziegler, B. 1977. The "White" (Upper) Jurassic in Southern Germany. Stuttgarter Beiträge zur Naturkunde (B) 26: 1-79.

Ziegler, P. A. 1990. Geological Atlas of Western and Central Europe. [2nd ed.] - 239 pp., 52 enclosures, The Hague (Shell Internationale Petroleum Maatschapij B.V.). 


\section{Index of authors}

Adachi, Natsuko ........................................ 37

Allen, Michelle............................................. 57

Aloisi, Giovanni ........................................ 38

Andres, Miriam S. ................................... 26

Arias, José Maria....................................... 81

Arning, Esther T...................................... 40

Arnold, Janine......................................... 117

Arp, Gernot.....................74, 120, 139, 166

Astibia, Humberto...................................... 41

Bąbel, Maciej .............................................. 42

Bach, Wolfgang......................................... 65

Banerjee, Neil R. ..................................... 95

Baskar, Ramanathan ............................... 44

Baskar, Sushmitha ................................... 44

Batchelor, Murray T............................... 80

Bauermeister, Jan. ................................... 72

Beer, Dirk de ........................................... 120

Beimforde, Christina.............................. 115

Benzerara, Karim ...................... 61, 67, 90

Beukes, Nic J. 116

Birgel, Daniel ....... 40, 45, 75, 78, 79, 131

Bissett, Andrew .................................... 120

Bogucki, Andrii ........................................ 42

Bohrmann, Gerhard ............................... 52

Bontognali, Tomaso .............................. 123

Borkowski, Andrzej............................. 128

Bosak, Tanja............................................ 104

Bouougri, El Hafid ..........................46, 105

Bourillot, Raphaël.................................... 48

Bowlin, Emily.......................................... 26

Braissant, Olivier................................19, 49
Brambilla, Evelyne.....................................59

Brasier, Martin D......................................96

Bréhéret, Jean Gabriel.......................51, 62

Brinkmann, Florian ...............................52

Brinkmann, Nicole .................................101

Brocks, Jochen J......................................... 17

Brown, Gordon E................................... 90

Brunner, Benjamin ................................... 40

Bühring, Solveig I....................................53

Burne, Robert V.................................54, 80

Burns, Brendan P..................................... 57

Chacón B., Elizabeth ................................. 58

Chekroun, Kaoutar Ben. .......................... 81

Cousin, Sylvie ..............................................59

Dattagupta, Sharmishtha .......................60

Decho, Alan W..................................19, 49

Demasi, Fabio .............................................. 93

Desaulty, Anne-Marie ...............................61

Détriché, Sébastien...................................62

Deville de Periere, Matthieu ...............124

Dittrich, Maria.........................................123

Dupraz, Christophe ...........................19, 49

Durlet, Christophe..................................124

Dynes, James J...........................................134

Ehinger, Susan .........................................64

Eickmann, Benjamin .............................65

Elorza, Javier ............................................. 41

Elshahed, Mostafa S. ............................... 53

Engel, Annette Summers ........................66

Erler, Beate .............................................. 117

Ertefai, Tobias.......................................... 53 
Ezaki, Yoichi ............................................37

Ferris, F. Grant......................................20

Fliegel, Daniel .......................................95

Fourmont, Agathe …................................51

Freiwald, André........................................78

Friedl, Thomas ..........................................101

Friedrich, Michael......................................2 24

Furnes, Harald............................................ 95

Gallagher, Kimberley L. ..........................49

Gaspar, Ana Patricia ..................................26

Gehler, Alexander. ........................................ 7

Gérard, Emmanuelle................................67

Gerasimenko, Ludmila M......................68

Gibson, Michael A......................................70

Gischler, Eberhard. .................................... 70

Glunk, Christina ..........................................49

Goh, Falicia.................................................57

Gonzalez-Muñoz, Maria Teresa. ..........81

Grazhdankin, Dmitriy.............................71

Guido, Adriano......................... 91, 93, 125

Guillemenet, A.......................................124

Guiraud, Michel......................................124

Hagemann, Andrea. ................................ 72

Hahmann, Uwe. ...................................... 74

Hedrich, Sabrina........................................ 73

Heim, Christine......................... 74, 88, 112

Heindel, Katrin............................... 75, 77

Heinzel, Elke............................................. 73

Heller, Christina............................. 108, 129

Himmler, Tobias. ...................................... 78

Hinrichs, Kai-Uwe ...................................53

Hoffmann, Lars. ......................................... 79

Hoffmann, Veit-Enno. .............................. 72

Hoppert, Michael.......................... 108, 129

Hori, Masako ...............................................21

Ibrahimi, Malika. .......................................67

Immenhauser, Adrian. ...........................131

Izuno, Gumpei........................................... 80

Jenk, Ulf....................................................117
Jiménez-Lopez, Concepción..................81

Jroundi, Fadwa. ......................................... 81

Kano, Akihiro...........................21, 82, 103

Kato, Kenji...............................................24

Kappler, Andreas....................................... 87

Karrat, L'houcine......................................62

Kassahun, Andrea.................................. 117

Kaushik, Anubha ......................................44

Kawai, Tatsuya .........................................21

Kazmierczak, Józef ...................61, 67, 83

Kempe, Stephan. ............................... 67, 83

Kiel, Steffen ................................................65

Köhler, Inga................................................ 87

Koike, Hiroko .......................................... 103

Kremer, Barbara ..........................42, 67, 83

Kronz, Andreas........................................... 72

Krüger, Martin ..........................................24

Krumholz, Lee R......................................53

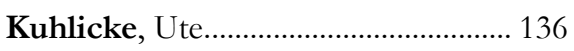

Kurz, Jens.................................................... 88

Lawrence, John R................................. 134

Lausmaa, Jukka.......................................... 74

Lebrón, Carmen ..................................... 100

Lee, Natuschka M.....................44, 66, 100

Leefmann, Tim. ….................................... 72

Lepland, Aivo ......................................... 137

Lepot, Kevin .............................................90

Liang, Biqing............................................. 104

Liebetrau, Volker...................................... 72

Liebl, Wolfgang ...................................... 100

Liu, Jianbo ..................................................... 37

Loeffler, Frank E.................................. 100

López-García, Purificación ............ 61, 67, 83, 108

López-Martínez, Nieves .........................41

Lückge, Andreas .........................................40

Macaire, Jean-Jaques ........................ 51, 62

Macalady, Jennifer L................................60

Macintyre, Ian G. ..................................26 
McKenzie, Judith 123

McLoughlin, Nicola $.95,96$

Makarikhin, Vladimir V. 97

Mastandrea, Adelaide $.91,93,125$

Matsuoka, Jun .. 21

Medvedev, Pavel V. 97

Meischner, Dieter 99

Meisinger, Daniela B. $.66,100$

Menguy, Nicolas...... .61

Mohr, Kathrin I. 101

Moreira, David $61,67,83,108$

Naganuma, Takeshi 103

Négrel, Philippe. 51

Neilan, Brett A 57

Neu, Thomas R. .120, 132, 134, 136

Nieto, Luís M. 110

Nishida, Shin 103

Norman, R. Sean . 19

Obst, Martin 134

Okumura, Tomoyo $.82,103$

Olszewska-Nejbert, Danuta . .42

Orleansky, Vladimir K. $.68,121$

Oschmann, Wolfgang. 70

Pack, Andreas. . .72

Paul, Josef $.54,139$

Pavlekovic, Marko. 100

Peckmann, Jörn .... 40, 45, 52, 65, 72, 75 , 78, 79, 131

Petroff, Alexander 104

Philippot, Pascal $.90,137$

Pierre, Catherine. 131

Porada, Hubertus. 105

Porter, Megan L. .66

Posth, Nicole R. ... 87

Przekop, Kristen M. 49

Rad1, Viviane 100

Ragon, Marie 108

Ramm, Jessica . 101

Reich, Mike
Reid, R. Pamela 19,26

Reimer, Andreas .120

Reitner, Joachim $65,72,88,108,112$, 114, 129, 139

Reolid, Matías 110,111

Richnow, Hans-H......................................24

Riding, Robert........................................... 27

Ritalahti, Kirsti M..................................100

Rodríguez-Gallego, Manuel. ................. 81

Rodríguez-Martínez, Marta.................112

Rohrbach, Nina ....................................... 117

Rothman, Daniel .....................................104

Rouchy, Jean-Marie ................. 48, 79, 131

Ruffolo, Silvestro Antonio...................... 93

Russo, Franco........................... 91, 93, 125

Sánchez-Beristáin, J. Francisco..........114

Schäfer, Nadine .......................................108

Schlömann, Michael................. 64, 73, 117

Schloter, Michael......................................100

Schmid, Michael............................... 66, 100

Schmidt, Alexander R............................115

Schmidt, Burkhard .................................... 88

Schröder, Stefan........................................ 116

Seibt, Kathrin...........................................117

Seifert, Jana .............................. 64, 73, 117

Seifert, Richard ......................................... 24

Serezhnikova, Ekaterina A. ..................118

Shimamoto, Toshihiko ............................ 82

Shiraishi, Fumito .......................... 103, 120

Sievert, Stefan M. ..................................... 53

Sim, Min Sub ...........................................104

Simon, Klaus ..................................... 88, 112

Sjövall, Peter............................................... 74

Śliwiński, Maciej......................................... 42

Stackebrandt, Erko...........................16, 59

Staudigel, Hubert ...................................... 95

Stolz, John F......................................19, 26

Sumin, D................................................ 121

Sumina, Evgenia ...................................... 121 
Sumner, Dawn Y. 116

Takashima, Chiduru .82, 103

Tavera, Rosaluz 67,83

Taviani, Marco .29

Theophilus, Paongaomai K. .44

Thiel, Volker. $.72,74,88,108$

Thorseth, Ingunn $\mathrm{H}$. ..30

Tosti, Fabio . .91

Totsche, Kai-Uwe. 100

Ushatinskaya, Galina T. .68

Van Kranendonk, Martin J. .31

Vasconcelos, Crisogono .123

Vennin, Emmanuelle 48,124

Vescogni, Alessandro 125

Vicens, Enric . .41

Visscher, Peter T. $19,49,123$

Warthmann, Rolf 127

Westall, Frances .35

Westphal, Hildegard $.75,77$

Wilson, Lucy A............................................ 96

Wisshak, Max..............................................77

Wolicka, Dorota. .....................................128

Wrede, Christoph. 108, 129

Yatsyshyn, Andrii . .42

Yukimura, Kise. .103

Zhang, Xingliang. 130

Zhegallo, Elena A. .68

Ziegenbalg, Simone. 79,131

Zilla, Thomas 112

Zippel, Barbara. .. 120, 132, 134, 136

Zuilen, Mark van .137 
Stromatolites are the most intriguing geobiological structures of the entire history of the earth since the early beginning of the fossil record in the Archaean. Traditionally, stromatolites and related microbial sediments are interpreted as biosedimentological remains of biofilms and microbial mats.

Stromatolites are important environmental and evolutionary archives that give us plenty of information on ancient habitats, biodiversity, and evolution of complex benthic biosystems. However, many aspects of the formation, biology, and geobiology of these structures are still cryptic and poorly understood.

The symposium is dedicated to Ernst Louis Kalkowsky (1851-1938), who introduced the terms "Stromatolith" and "Ooid" to the earth science community in 1908.

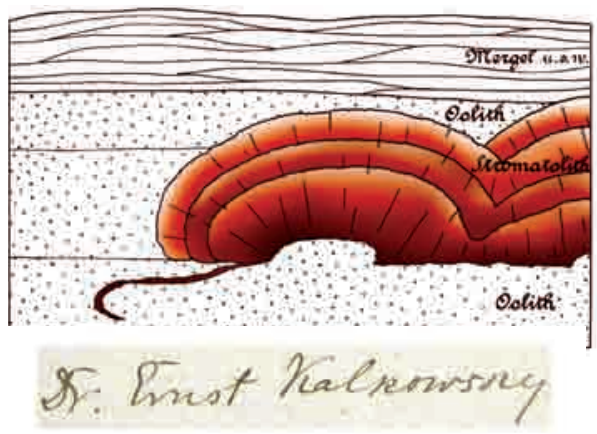

